PNL-7110

UC-402

3

\title{
Chernobyl Bibliography
}

F. Carr, Jr.

J. A. Mahaffey

September 1989

Prepared for the U.S. Department of Energy under Contract DE-AC06-76RLO 1830

Pacific Northwest Laboratory

Operated for the U.S. Department of Energy by Battelle Memorial Institute 


\title{
DISCLAIMER
}

This program was prepared as an account of work sponsored by an agency of the United States Government. Neither the United States Government nor any agency thereof, nor Battelle Memorial Institute, nor any or their employees, makes any warranty, expressed or implied, or assumes any legal liability or responsibility for the accuracy, completeness, or usefulness of any information, apparatus, product, or process disclosed, or represents that its use would not infringe privately owned rights. Reference herein to any specific commercial product, process, or service by trade name, trademark, manufacturer, or otherwise, does not necessarily constitute or imply its endorsement, recommendation, or favoring by the United States Government of any agency thereof, or Battelle Memorial Institute. The views and opinions of authors expressed herein do not necessarily state or reflect those of the United States Government or any agency thereof.

\author{
PACIFIC NORTHWEST LABORATORY \\ operated by \\ BATTELLE MEMORIAL INSTITUTE \\ for the \\ UNITED STATES DEPARTMENT OF ENERGY \\ under Contract DE-ACO6-76RLO 1830
}

Printed in the United States of America

Available to DOE and DOE contractors from the

Office of Scientific and Technical Information, P.O. B $1 \times 62$, Oak Ridge. TN 37831: prices available from (615) $576-8401$. FTS 626-8401.

Available to the public from the National Technical information Service, U.S. Department of Commerce, 5285 Port Royal Rd. Springfield, VA 22761.

NTIS Price Codes, Microtiche $N 0 T$

\begin{tabular}{cc}
\multicolumn{2}{c}{ Printed Copy } \\
& $\begin{array}{c}\text { Price } \\
\text { Pages }\end{array}$ \\
\hline $001-025$ & Codes \\
$026-050$ & A02 \\
$051-075$ & A03 \\
$076-100$ & A04 \\
$101-125$ & A05 \\
$126-150$ & A06 \\
$151-175$ & A07 \\
$176-200$ & A08 \\
$201-225$ & A09 \\
$226-250$ & A10 \\
$251-275$ & A1T \\
$276-300$ & A12 \\
& A13
\end{tabular}


CHERNOBYL BIBLIOGRAPHY

F. Carr, Jr.

J.A. Mahaffey

September 1989

Prepared for

the U.S. Department of Energy

under Contract DE-ACO6-76RLO 1830

Pacific Northwest Laboratory

Richland, Hashington 99352 


\section{SUMMARY}

The purpose of the DOE/OHER Chernobyl Database project is to create and maintain an information system to provide usable information for research studies related to the Chernobyl nuclear accident. The system is the official United States repository for information about the Chernobyl accident and its consequences, and currently includes an extensive bibliography and diverse radiological measurements with supporting information. PNL has established two resources: original (not summarized) measurement data, currently about 80,000 measurements, with ancillary information; and about 2200 bibliographic citations, some including abstracts. Researchers can retrieve this information by dialing into a PNL microvax and using on-line menus and forms, or by requesting information from project staff on magnetic media or in printed form.

Data and reference materials have been obtained from domestic and foreign organizations and individuals, and expansion of resources is an ongoing activity. As a result of the type of much information that is now being received, summarized data, a third resource will be added to the Chernobyl Database. We plan to investigate computerizing images of maps, graphs, plots, charts, and tables of summarized data, and include ancillary information about the image from source reports and publications.

Major organizations that have contributed radiological measurement data include the Washington State Department Of Social And Health Services; United States Environmental Protection Agency (domestic and foreign data); United States Nuclear Regulatory Commission; Stone \& Hebster; Brookhaven National Laboratory; Comnissariat A L'energie Atomique in France; Ministry of Agriculture, Fisheries, and Food in the United Kingdom; Japan National Institute of Radiological Sciences; and the Finnish Centre For Radiation and Nuclear Safety (STUK). Scientists in Australia, Austria, Belgium, Canada, China, Denmark, England, Federal Republic of Germany, Finland, France, Ireland, Italy, Japan, the Netherlands, Romania, Scotland, Spain, Sweden, Switzerland, United States, Wales, and Yugoslavia have made contributions.

Bibliographic materials have been obtained from scientists in the above countries that have replied to requests. Many other requests have been made. In addition, literature searches have been conducted, including a search of the DOE Energy Database. The last search was conducted in January, 1989.

Use of information contained in the system allows researchers to evaluate historical risk, transport, and deposition models previously developed based on data from laboratory experiments, theoretical calculations, computer simulations, and limited real data. It also allows a variety of other research activities. Ability to access reference materials is important to many of these. The following is the bibliographic information in the DOE/OHER Chernobyl Database at the current time. 
Aarkrog, A. 1986. An Estimate of the Expected Doses from the Consumption of Danish Foodstuffs Contaminated by Radiocesium from the Chernobyl-Accident, with an Appendix on Sr-90. Riso National Laboratory, Riso.

Aarkrog, A. 1988. "Radiological impact of the Chernobyl debris compared with that from nuclear weapons fallout." J. Environ. Radioact. 6(2):151-162.

Aarkrog, A. 1987. Final report on Risoe measuring program in connection with Chernobyl accident. Risoe National Lab, Roskilde, Denmark.

Aarkrog, A.; Carlsson, L.; Chen, Q.J.; Dahlgaard, H.; Jensen, L.H.; Nielsen, S.P.; Holm, E. 1988. "Origin of technetium-99 and its use as a marine tracer." Nature 335(6188):338-340.

Aarkrog, A.; Nielsen, S.P.; Dahlgaard, H.; Lauridsen, B.; Soegaard-Hansen, J. 1988. Final report of the Risoe monitoring programe after the Chernobyl accident for the period 0ct 1, 1986-Sept 30, 1987. Appendix 2. Chernobyl monitoring data compiled. RISO-M-2692-App.2, Risoe National Lab, Roskilde, Denmark.

Aarkrog, A.; Nielsen, S.P.; Dahlgaard, H.; Lauridsen, B.; Soegaard-Hansen, J. 1988. Final report on the Risoe monitoring programme after the Chernobyl accident for the period October 1, 1986-September 30, 1987. Main Report. RISO-M-2692, Risoe National Lab, Roskilde, Denmark.

Aarkrog, A.; Nielsen, S.P.; Dahlgaard, H.; Lauridsen, B.; Sxgaard-Hansen, J. 1988. Final report of the Risoe monitoring programme after the Chernobyl accident for the period October 1, 1986-September 30, 1987. Appendix 1. Descriptions of monitoring programme. RISO-M-2692-App.1, Risoe National Lab, Roskide, Denmark.

Abdul-Fattah, A.F.; Mamoon, A.M.; Abdul-Majid, S. 1987. "Monitoring of radioactivity in imported foodstuffs - experience gained and recommendations." Trans. Am. Nucl. Soc. 54:40-41.

Abe, S. 1987. "Radioactive substance in the Japanese environment. Focused on the radioactivity originated from the Chernobyl Nuclear Power Station." Shokuhin Eisei Kenkyu 37(10):7-24.

Abrams, H.L. 1986. "How radiation victims suffer." Bull. At. Sci. $43(1): 13-17$.

Abulfaraj, H.H.; Abdul-Majid, S.; Abdul-Fattah, A.F. 1987. "Radiation monitoring of imported food to Saudi Arabia after Chernobyl." Trans. Am. Nuc 1 . Soc. $54: 39-40$.

Achkasov, S.K.; Badyaev, V.V.; Egorov, Yu.A.; Ivanov, E.A.; Krasnozhen, G.N.; Korobejnikov, V.L. 1985. Complex investigations of contamination level of atmospheric surface air with noble radioactive gases in the Chernobylsk NPP zone being under survey. Ehnergoatomizdat, Moscow, U.S.S.R. 
Ackers, J.G.; Julius, H.W.; Verhoef, C.W.; Aten, J.B.T.; Gerritsen, A.J.M. 1986. Results of measurements of internal contamination of persons caused by the chernobyl accident. Document 15-1. Gezondheidsorganisatie TNO, Arnhem, Netherlands.

Adamov, E.0.; Asmolov, V.G.; Vasilevskii, V.P.; Egorov, Yu.A.; Kalugin, A.K.; Nikitin, Y.M.; et a]. 1987. "Increasing the safety of atomic power stations with RBMK reactors." Sov. At. Energy 62(4):255-263.

Adamov, E.0.; Asmolov, V.G.; Vasilevskij, V.P.; et al. 1987. "Increasing the safety of NPPS with the RBMK reactors." At. Energ. 62(4):219-226.

Adamov, E.0.; Vasilevskij, V.P.; Ionov, A.I.; et al. 1988. "Analys is of the first stage in the reactor accident development at the Chernobyl NPP fourth unit." At. Energ. 64(1):24-28.

Adolph, J.; Boettcher, J.; Frenzel, E.; Kreiner, H.J.; Iwatschenko, M.; Witthuhn, W. 1986. "On-line measurement of the specific areosol activity in the Federal Republic of Germany following the Chernobyl accident." ATW, Atomwirtsch., Atomtech. 31(7):393-394.

Ahearne, J.F. 1987. "Nuclear power after Chernobyl." Science 4802:673-679.

Aigner, R.; Melzer, E.; Seissler, H. 1986. Radiation protection primer. What everybody should know, observe, avoid, or do for his own personal protection in an environment affected by the Chernobyl accident. Heyne, Muenchen, Germany, F.R.

Akaishi, J.; Ohhata, T. 1987. "Review on contamination and emergency response actions in USSR, European countries and Japan in the reactor accident at Chernoby1." Hoken Butsuri 22(2):209-216.

Al-Kusayer, T.A.; Al-Haj, A.N. 1987. "Measurement of the natural radiation background level of Riyadh City." Trans. Am. Nucl. Soc. 55:87-89.

Albano, R. 1986. "Present Tegal problems should nuclear incidents occur." Rass. Giurid. ENEL 3(3):585-595.

Albergel, A. 1988. "Dispersion of Chernobyl radioactive plume over Europe." Bull. Dir. Etud. Rech., Electr. Fr., Ser. A $4: 4$.

Albertazzi, S.; Pelati, L.T.; Merlin, 0.H.; Vitturi, L.M.; Molinaroli, E. 1987. "Distribution and behaviour of $\mathrm{Cs}-137$ in nearshore sediments of the northern Adriatic and at the Adige River estuary, northern Italy." Appl. Geochem. 2(4):357-366.

Albracht, G.; Horstmann, H.: Tuerck, D.; Koerner, H.J.; Ott, W.; Plath, D.; et al. 1987. Long-termed measuring programme in Hesse, for radioactivity monitoring after the Chernobyl reactor accident. Hessische Landesanstait fuer Jimwelt, Wiesbaden, Germany, F.R. 
Albrecht, H. 1986. "On the sequence of core-melt accidents: Fission product release, source terms and Chernobyl release." KFK-Nachr. 18(3):150-157.

Albrecht, H. 1987. "Radioactivity emission from the Chernobyl accident in comparison with the results of the SASCHA program." Radiochim. Acta $41(4): 141-143$.

Albrecht, H. 1986. "Course of core meltdown accidents: Fission product release, source terms and Chernobyl emission." In Colloquium of the Projekt Nukleare Sicherheit (PNS) of the Kernforschungszentrum Karlsruhe G.m.b.H. Kernforschungszentrum Karlsruhe G.m.b.H., Germany, F.R.

Aleksashin, P.P.; Bukrinskij, A.M.; Kovalevich, 0.M.; Malyshev, V.M. : Sidorenko, V.A. 1987. "Developmet of safety demands and state supervision system as a basis for safe development of nuclear power." At. Energ. $63(5): 306-310$.

Alexandropoulos, N.G.; Alexandropoulos, T.; Anagnostopoulos, 0.; Evangelou, E.; Kotsis, K.T.; et al. 1986. "Chernobyl fallout on Ioannina, Greece." Nature 322(6082):779.

Ali, P.A.; Birks, J.L.; Morgan, W.D.; Hughes, M.G.; Ryde, S.J.S.; Sivyer, A.; Haywood, A. 1986. Whole-body radioactivity of subjects returning from Russia and of Swansea residents. Institute of Physical Sciences in Medicine, London, U.K.

Aliesch, P. 1987. "Does Switzerland need a new energy policy?" Electro-Rev. $79(20): 9-12$.

Allen, A.M. 1986. "Chairman's speech." Atom 361:10-12.

American Medical Association. 1986. "International conference on non-military radiation emergencies: (Final technical report)." In International conference on non-military radiation emergencies. American Medical Association, Chicago, IL, U.S.A.

Amman, F. 1987. "An alternative development strategy for the nuclear industry." Energ. Innov.: Notiz. ENEA 33(5):9-19.

Amnar, E.A.; El-Khatib, A.M.; Wahba, A.G.; Elraey, M. 1987. "Radioactive contamination from Chernobyl accident over Alexandria city." Isotopenpraxis $23(8): 303-305$.

Anders, H.J.; Rosenbauer, J.; Matiaske, B. 1987. "Change of attitude and behaviour of the West-German population after the Chernobyl reactor accident." Ernaehr.-Umsch. 34(8):255-257.

Andrasi, A. 1987. "Radiological consequences of the Chernobyl accident for Hungary." Radiat. Prot. Dosim. 19(4):239-245. 
Andrasi, A.; Beleznay, E.; Deme, S.; Feher, I.; Koblinger, L.; Lancsarics, Gy.; Lang, E. 1986. Monitoring the radiation consequences due to the disaster at the Chernobyl nuc lear facility from April 28 to June 12, 1986. Hungarian Academy of Sciences, Budapest, Hungary.

Andrasi, A.; Nemeth, I.; Zombori, P. 1987. Application of Ge-spectrometry for rapid in-situ determination of environmental radioactivity. Hungarian Academy of Sciences, Budapest, Hungary.

Anon. 1987. German Weather Service. Annual report 1986. Selbstverl. des Deutschen Wetterdienstes, Offenbach am Main, Germany, F.R.

Anon. 1987. Post Chernobyl-4. Exposure rate measurements at Saluggia (Vercelli). ENEA, Rome, Italy.

Anon. 1988. Monthly results of measurements, Apr 1988. SCPRI-RM-4-1988, Service Central de Protection contre les Rayonnements Ionisants, France.

Anspaugh, L.R.; Goldman, M.; Catlin, R.J. 1987. "Atmospheric releases from severe nuclear accidents: Environmental transport and pathways to man: Modelling of radiation doses to man from Chernobyl releases." In International conference on the technical and economic performance of nuclear power. Lawrence Livermore National Lab., Livermore, CA, U.S.A.

Anttila, P.; Kulmala, M.; Raunemaa, T. 1987. "Dry and wet deposition of Chernobyl aerosols in Southern Finland." J. Aerosol Sci. 18(6):939-942.

Aoyama, M. 1988. "Evidence of stratospheric fallout of caesium isotopes from the Chernobyl accident." Geophys. Res. Lett. 15(4):327-330.

Aoyama, M.; Hirose, K.; Sugimura, Y. 1987. "Deposition of gamma-emitting nuclides in Japan after the Reactor-IV accident at Chernobyl'." J. Radioanal. Nuc 1. Chem. 116(2):291-306.

Aoyama, M.; Hirose, K.: Suzuki, Y.: Inoue, H.: Sugimura, Y. 1986. "High TeveT radioactive nuclides in Japan in May." Nature 321(6073):819-820.

ApSimon, H.: Wilson, J. 1986. "Tracking the cloud from Chernobyl." New Sci. $111(1517): 42-45$.

ApSimon, H.M. and Wilson, J.J.N. 1986. "Preliminary Analys is of Dispersion of the Chernobyl Release" In Nuclear Installations Inspectorate HQ. Lawrence Livermore National Lab., Livermore, CA, U.S.A.

ApSimon, H.M.; Wilson, J.J.N. 1987. "Dispersion modelling after Chernoby1." In Conference on nuclear risks - reassessing the principles and practical after Chernoby 1. IBC Technical Services Ltd., London, U.K.

ApSimon, H.M.; Wilson, J.J.N.; Guirguis, S.; Stott, P.A. 1987. "Assessment of the Chernobyl release in the imnediate aftermath of the accident." Nucl. Energy 26(5):295-301. 
ApSimon, H.M.; Wilson, J.J.N.; Macdonald, H.F. 1986. "Initial assessment of the Chernobyl -4 reactor accident release source." J. Soc. Radiol. Prot.

6(3): 109-119.

Apostolakis, G. 1987. "Uncertainty in probabilistic safety assessment." In 9. SMIRT: international conference on structural mechanics in reactor technology. Wittmann, F.H. (ed.), Balkema, Rotterdam, Netherlands.

Arbeitsgemeinschaft der Grossforschungseinrichtungen (AGF). 1986. "Chernoby1 and the future of energy supplies in the Federal Republic of Germany. Summaries." In AGF congress on Chernobyl and the future of energy supply in the Federal Republic of Germany. Arbeitsgemeinschaft der

Grossforschungseinrichtungen ( $A G F$ ), Bonn, Germany, F.R.

Arbeitsgemeinschaft der Grossforschungseinrichtungen (AGF). 1987. "Chernobyl and the future of energy supply in the Federal Republic of Gemany." In AGF congress on Chernobyl and the future of energy supply in the Federal Republic of Germany. Arbeitsgemeinschaft der Grossforschungseinrichtungen (AGF), Bonn, Germany, F.R.

Arnold, L. 1986. "Nuclear power: restoring public confidence." Atom $359: 12-14$.

Arnott, D.G. 1987. Study into the consequences of a nuclear accident. Wrekin District Council, Telford, U.K.

Arvela, H.; Blomqvist, L.; Lemmelae, H.; Savolainen, A.L.; Sarkkula, S. 1987. Environmental gamma radiation measurements in Finland and the influence of the meteorological conditions after the Chernobyl accident in 1986. Supplement 10 to annual report STUK-A55. Finnish Centre for Radiation and Nuclear Safety, Helsinki, Finland.

Asahi, Y. 1987. "Safety analysis of inherent safety reactors." Genshiryoku Kogyo $33(1): 59-63$.

Asahi, Y.; Lee, W.; Wakabayashi, H. 1987. "Application of PIUS approach to PWR." In International nuclear engineering symposium on the development and use of small and medium size power reactors in the next generation. CONF-8611129, Tokai Univ., General Research Organization, Tokyo, Japan.

Asmolov, V.G.; Borojov, A.A.; Demin, V.F.; et al. 1988. "Accident at the Chernoby 1 nuclear power plant: One year after." In International conference on nuclear power performance and safety. CONF-8709263, IAEA, Vienna, Austria.

Asselstine, J. 1986. What the Chernobyl accident means for the US nuclear power program. Nuclear Information and Resource Service, Washington, DC, U.S.A.

Asselstine, J.K. 1987. "Regulating a multiplicity of power utility companies." In Conference on nuclear risks - reassessing the principles and practical after Chernobyl. IBC Technical Services Ltd., London, U.K. 
Asselstine, J.K. 1987. "Future of nuclear power after Chernobyl." Va. J. Nat. Resour. Law 6(2):239-261.

Assimakopoulos, P.A.; Ioannides, K.G.; Pak; Paradopoulou, C.V. 1987. "Transport of the radioisotopes iodine-131, cesium-134, and cesium-137 from the fallout following the accident at the Chernobyl nuclear reactor into cheesemaking products." J. Dairy Sci. 70(7):1338-1343.

Atomic Energy Commission. 1987. Long-term program for development and utilization of nuclear energy. Atomic Energy Commission, Tokyo, Japan.

Australian Atomic Energy Comission Research Establishment. 1986. Chernobyl nuclear accident and its consequences. Australian Atomic Energy Commission Research Establishment, Lucas Heights, Austrailia.

Australian Atomic Energy Commission Research Establishment. 1986. First report of the task group on the accident at the Chernobyl nuclear power plant. Australian Atomic Energy Comission Research Establishment, Lucas Heights, Austrailia.

Axtone, G. 1987. Nuclear risk: Analysis of the Soviet report on Chernobyl accident. UNICOPLI, Mi lan, Italy.

BUNR. 1986. Bericht ber den Reaktorunfall in Tschernobyl, seine Auswirkungen und die getroffenen bzw. zu treffenden Vorkerungen Der Bundesminster fur Unwelt, Naturschutz und Reaktorsicherheit (BUNR), Federal Republic of Germany.

Babaev, N.S.; Kuchinov, V.P.; Semenov, B.A.; Legasov, V.A.; Sukhoruchkin, V.K. 1988. "International system of measures for ensuring the safe development of nuclear power." In International conference on nuclear power performance and safety. CONF-8709263, IAEA, Vienna, Austria.

Backe, S.: Bjerke, H.; Rudjord, A.L.; Ugletveit, F. 1986. Cesium fallout in Norway after the Chernobyl accident. Statens Inst. for Straalehygiene, 0s To, Norway.

Backe, S.; Bjerke, H.; Rudjord, A.L.; Ugletveit, F. 1987. "Fall-out pattern in Norway after the Chernobyl accident estimated from soil samples. "Radiat. Prot. Dosim. 18(2):105-107.

Bacon, M.P. 1987. "Ocean flux of Chernobyl fallout." Nature $329(6142): 767-768$.

Badolato, E.V. 1986. "Nuclear safeguards and security in a changing world." Nucl. Mater. Manage. 15:1-5.

Badolato, E.V. 1986. "Nuclear safety and security in a changing world." $\mathrm{J}$. Inst. Nucl. Mater. Manage. 15(1):13-17. 
Badyaev, V.V.: Egorov, Yu.A.; Korobejnikov, V.L.; Krasnozhen, G.N.; Stegachev, G.F.: Tolstykh, V. 1985. Results of monitoring of tritium behaviour and its concentration in the objects of Chernobylsk NPP environment. Ehnergoatomizdat, Moscow, U.S.S.R.

Badyaev, V.V.; Klejmenov, A.G.; Sobolev, V.A.; Sermanov, A.V. 1986.

Efficiency of the systems for gas and aerosol medium purification at NPPs with RBMK reactors. Egorov, Yu.A. (ed.), Ehnergoatomizdat, Moscow, U.S.S.R.

Badyaev, V.V.; Korobejnikov, V.L.; Stegachev, G.F.; Tolstykh, V.D. 1985. On the bioindication of NPP gaseous-aerosol discharges in the environment. Egorov, Yu.A. (ed.), Ehnergoatomizdat, Moscow, U.S.S.R.

Baggenstos, M.; Isaak, H.P. 1987. "Interactions between multiple organizations responding to a reactor accident in Switzerland." In Radiological accidents, perspectives and emergency planning preparedness. Swiss Nuclear Safety Inspectorate, Wuerenlingen, Switzerland.

Bailey, M.R.; Dodd, N.J.; Etherington, G.; Hudson, A.P.; Wheatley, J. 1987. Measurements of the body content of radioactive caesium in residents of Yorkshire. National Radiological Protection Board, Chilton, U.K.

Bailey, R. 1987. "Energy policy after Chernobyl." Nat1. Westminster Bank, Q. Rev. p. 2-14.

Bain, C.A.R.; Annandale, J.; Moolman, E.W. 1987. Environmental radioactivity at the National Nuclear Research Centre, Pelindaba: report for the year 1986. PER-162, Atomic Energy Corp. of South Africa (Pty) Ltd., Pretoria, South Africa.

Baker, J. 1988. "Case for further nuclear power stations." J. Chem. Technol. Biotechnol. $41(3): 167-171$.

Baker, K.; Kellett-Bowman, E.; Robertson, J.H. 1986. "Nuclear energy: debate on Chernobyl, radioactive waste, etc. "Hansard, House Conmons Off. Rep. $97(112): 568-654$.

Balashazy, I.; Feher, I.; Szabadyne-Szende, G.; Lorinc, M.; Zombori, P.; Pogany, L. 1988. "Examination of hot particles collected in Budapest

following the Chernobyl accident." Radiat. Prot. Dosim. 22(4):263-267.

Balashazy, I.; Szabadine-Szende, G.; Loerinc, M.; Zombori, P. 1987. Ganma-spectrometric examination of hot particles emitted during the Chernobyl accident. Hungarian Academy of Sciences, Budapest, Hungary.

Baldinger, 0. 1986. "Chernobyl: the development has to serve mankind." Neue Tech. $28(8): 3$.

Baldini, E.; Bettoli, M.G.; Tubertini, 0. 1987. "Chernobyl pollution in forest biogeocenoses." Radiochim. Acta 41(4):199-201. 
Ballard, G.M. 1987. "Small incidents - precursors to disaster or aids to safe operation." In Conference on nuclear risks - reassessing the principles and practical after Chernobyl. IBC Technical Services Ltd., London, U.K.

Ballard, G.M. (ed.). 1988. "Nuclear safety after Three Mile Island and Chernoby1." In International approach to nuclear safety seminar. CONF-8806174, ETsevier Applied Science, London, U.K.

Ballestra, S.B.; Holm, E.; Walton, A.; Whitehead, N.E. 1987. "Fallout deposition at Monaco following the Chernobyl accident." J. Environ. Radioact. $5(5): 391-400$.

Baltensperger, U.; Gaeggeler, H.H.; Jost, D.T.; Zinder, B.; Haller, P. 1987. "Chernobyl radioactivity in size-fractionated aerosol." J. Aerosol Sci. $18(6): 685-688$.

Banaschik, M.V.; Berg, K.H. 1986. "National report: Germany, Federal Republic of. Steps for safety." IAEA Bull. 28(3):35-36.

Bannasch, P. 1987. Cancer risks: Strategies for elimination. Springer-Verlag New York Inc., New York, NY, U.S.A.

Barci, G.; Dalmasso, J.; Ardisson, G. 1987. "Chernobyl fallout measurements in some Mediterranean biotas." J. Radioanal. Nucl. Chem. 117(6):337-346.

Barci, G.; Dalmasso, J.; Ardisson, G. 1988. "Chernobyl fallout measurements in some Mediterranean biotas." Sci. Total Environ. 70:70.

Barendsen, G.W. 1987. "Effects of ionizing radiation on man in relation to the Chernobyl accident. Chapter 9." In Chernobyl - environment and hea]th aspects. Van Loon, A.J. (ed.), KIVI-Kerntechniek, Arnhen, Netherlands.

Barker, F. 1987. "Councils' Chernobyl response." SCRAM: Anti-Nucl. Safe Energy J. $61: 18$.

Barnert, H. 1987. "Advanced nuclear energy technology." In AGF congress on Chernobyl and the future of energy supply in the Federal Republic of Germany. Kernforschungsanlage Juelich G.m.b.H., Germany, F.R.

Barnert, H. 1988. "Nuclear power, a foundation of future energy supply systems." In 4. annual meeting of the VDI-Gesellschaft Energietechnik: energy and engineering for our future. CONF-880281, VDI-Verl., Duesseldorf, Germany, F.R.

Barry, R. 1988. "It's all systems go for nuclear." Europe 88 p. 3-6.

Barthelt, K. 1987. "Perspectives of development in nuclear industry." ATH, Atomwirtsch., Atomtech. 32(8/9):398-402.

Barthelt, K. 1986. "Chernobyl reactor accident and how it changed the world." KWU-Rep. $46: 1-7$. 
Baschek, H.F. 1988. "Retrofitting Swiss nuclear power plants." Schweiz. Tech. Z. $85(14): 13-16$.

Basic, M.; Kasal, B.; Simonovic, I.; Jukic, S. 1988. "I-131 dose to the human fetal thyroid in the Zagreb district, Yugoslavia, from the Chernobyl accident." Int. J. Radiat. Biol. 54(2):167-177.

Bastian, T. 1986. Nuclear disasters and their consequences. An information brochure for critical citizens. Jungjohann, Neckarsulm, Germany, F.R.

Batarekh, K.; Teherani, D.K. 1987. "Determination of Pu-239 in soil samples from Austria after the Chernobyl accident." J. Radioanal. Nucl. Chem. $118(6): 415-420$.

Batarekh, M.K.; Teherani, D.K. 1987. "Determination of strontium-90 in various kinds of water after Chernobyl accident in Austria." J. Radioanal. Nucl. Chem. 108(3):133-138.

Bauer, L.; Gilli, P.V.; Obermair, G. 1986. "Comnunication by the Austrian National Committee of the World Energy Conference. 13th Congress of the World Energy Conference (Cannes, 5th to 10th October 1986). " Oesterr. $Z$. Elektrizitaetswirtsch. 39(12):A160-A164.

Baum, V. 1986. "World electricity: will nuclear doubts affect growth?" Pet. Econ. 53(8):291-293.

Baum, V. 1987. "Nuclear power after Chernobyl." Pet. Econ. 54(11):395-397.

Baust, E. 1988. "Future of high-temperature reactors (HTR)." At. Strom $34(1 / 2): 6-11$.

Baust, E.; Schoening, J. 1987. "HTR 500: The basic design for commercial HTR power stations." In IAEA technical committee meeting on gas-cooled reactors and their applications. Hochtemperatur-Reaktorbau G.m.b.H., Mannheim, Germany, F.R.

Baverstock, K.F. 1986. "Preliminary assessment of the consequences for inhabitants of the UK of the Chernobyl accident." Int. J. Radiat. Biol. $50(1): i i j-x i i j$.

Baverstock, K.F.; Bowlt, C. 1987. "Iodine in thyroid glands after Chernobyl." J. Soc. Radiol. Prot. 7(4):195-196.

Baverstock, K.F.; Darley, P.J.; Nair, S. 1986. "Comments on 'A preliminary assessment of individual doses in the environs of Berkeley, Gloucestershire, following the Chernobyl nuclear reactor accident' and reply." J. Soc. Radiol. Prot. 6(4):192-194.

Bayer, A. 1986. "Opening address by the Secretary of State in the Federal Ministry of Transport on the occasion of the opening of the 'ELTEC '86'." In ELTEC '86: exhibition for electrical engineering. Bundesministerium fuer Verkehr, Bonn, Germany, F.R. 
Bayerisches Staatsministerium fuer Landesentwicklung und Umweltfragen. 1987. Chernobyl reactor accident and its impact on Bavaria. Bayerisches Staatsministerium fuer Landesentwicklung und Umweltfragen, Muenchen, Germany, F.R.

Beck, H.L.; Dreicer, M.; Helfer, I.K.; Geduldig, J. 1986. Study of the collection efficiency of gummed-film for fission products. Volchok, H.L.i Chieco, N. (eds.), USDOE Environmental Measurements Lab., New York, NY, U.S.A.

Becker, D.V. 1986. "Reactor accidents." In International conference on non-military radiation emergencies. DOE/ER/60525-1, New York Hospital-Cornell Medical Center, NY, U.S.A.

Becker, J.M.H. 1986. "Portable Geiger counter with TTL-computer interface." Pract. Electron. 22(8):30-35.

Becker, K.; Maurer, H.A. 1987. "International harmonization of nuclear standards. Possibilities and limits." ATW, Atomwirtsch., Atomtech. $32(10): 480-483$.

Becker, U. 1987. "Draft amendment to the X-Ray Ordinance." In 27. annual conference of Vereiniqung Deutscher Strahlenschutzaerzte e.V. Schuetz, J.; Boerner, W.; Messerschmidt, 0. (eds.), CoNF-8605338, Thieme, Stuttgart, Germany, F.R.

Beckurts, K.H. 1986. "Continuing after Chernobyl. Nuclear energy use with caution is sti11 necessary." Zeit $41(30): 32$.

Beentjeis, L.B.; Duijsings, J.H.: Buijs, W.C.; Corstens, F.H. 1988.

"Radioactive contamination of $\mathrm{Kiev}$ vacationers after the Chernobyl accident. Biological half-life of Cs." Nucl. Med. Biol. 15(2):171-175.

Beentjes, L.B.; Duijsings, J.H. 1987. "Radioactive contamination in Nijmegen rainwater after the Chernobyl accident." Sci. Total Environ. 64(3):253-258.

Behrend, U.; Dulski, P.; Friedland, E.M.; Gawlik, D.; Kirschfeld, K.E.; Schubert, P. 1987. Radioactivity measurements of the HMI after the Chernobyl reactor accident. Hahn-Meitner-Inst itut fuer Kernforschung Berlin G.m.b.H., Berlin, Germany, F.R.

Beirat Unweltforschung des Landes Baden-Wuerttemberg (BULBW). 1987. "Forum on impact of radioactive materials on the atmospheric pollutant inventory and on the radioactivity uptake by plants. Papers and discussions." In Forum on impact of radioactive materials on the atmospheric pollutant inventory and on the radioactivity uptake by plants. Beirat Unweltforschung des Landes Baden-huerttemberg (BULBW), Karlsruhe, Germany, F.R. 
Beiriger, J.M.; Failor, R.A.; Marsh, K.V.; Shaw, G.E. 1987. "Radioactive fallout from the Chernobyl nuclear reactor accident." In 33 . annual bioassay analytical and environmental radiochemistry conference. Lawrence Livermore National Lab., Livermore, CA, U.S.A.

Belgian Study Centre for Nuclear Energy. 1986. "Accident of Chernobyl Report of the Measurements from 1 to 31 May 1986" In WH0 Expert Meeting on the Chernobyl Accident. Lawrence Livermore National Lab., Livermore, CA, U.S.A.

Belgrave, R. 1987. "Energy security to 2000. Address to the Parliamentary Group for Energy Studies, 14th January 1987." Energy Focus 4(1):13-28.

Belli, M.; Feroce, C.; Poggi, M.; Sansone, U. 1987. Radiological survey of Abruzzo and Molise Regions in Italy (15-23 July 1986). ENEA-RT-DISP-87-6, ENEA, Rome, Italy.

Belstead, G.; Thurso, E. 1986. "Food protection (emergency prohibitions) (England) (No.2) Order 1986." Hansard, House Lords. Off. Rep. $481(160): 886-894$.

Benecke, J. 1986. "Atom: The fatal energy." In Meeting on after the Chernobyl accident: how safe is our food?. CONF-8606412, Stiftung Verbraucherinstitut, Berlin, Germany, F.R.

Bengtsson, G. 1986. "What has happened to the radiation environment after the Chernobyl accident?" In Conference on radiation and health hazards: Chernoby] in perspective. National Inst. of Radiation Protection, Stockholm, Sweden.

Bengtsson, G. 1986. What does Chernobyl teach us? National Inst. of Radiation Protection, Stockholm, Sweden.

Beninson, D.; Lindel1, B. 1986. Chernobyl reactor accident: report of a consultation. World Health Organization, Copenhagen, Denmark.

Bennerstedt, T.; Holmberg, M.; Lindborg, L. 1986. Chernobyl - fallout, measurements and consequences. National Inst. of Radiation Protection, Stockholm, Sweden.

Bennett, L.L.; Skjoeldebrand, R. 1986. "Worldwide nuclear power status and trends. Nuclear's contribution to electricity supply is growing." IAEA Bull. $28(3): 40-45$.

Beranek, J. 1987. "Securing safety is precondition of nuclear power development." Jad. Energ. $33(1): 1-2$.

Berbushenko, A.A.; Vedernikov, A.V.; Zagrebaev, A.M.; Ivanenko, V.G. : Pryanichnikov, V.A. 1987. On the organization of a computer-based file of operational parameters for NPPS with the RBMK type reactors. INIS-SU-55, Tsentral'nyj Nauchno-Issledovatel'skij Inst. Informatsii $i$

Tekhniko-Ehkonomiches, U.S.S.R. 
Berg, D.; Kollmer, W.E.; Kriegel, H. 1987. "Whole body measurements in children and adults in the area of Munich after the reactor accident of Chernoby1." Nuklearmediziner 10(1):87-92.

Berg, D.; Kollmer, W.E.; Kriegel, H.; Bogner, L.; Czempiel, H.; Muehle, P. 1987. "Whole body measurements in children and adults in Munich between May and Decenber 1986." Nuklearmediziner 10(5):353-358.

Berg, J.0.; Christensen, G.; Lingjaerde, R.; Smidt 0lsen, H.; Wethe, P.I. 1986. Chernobyl accident. Course of events - health hazards - consequences. Institute for Energy Technology, Kjeller, Norway.

Bergendah1, P.A. 1986. Energy markets and price relations. After Chernobyl. Statens Energiverk, Stockholm, Sweden.

Bergman, C.; Boge, R.; Snihs, J.0. 1987. "Decommissioning policy in Sweden." In International decommissioning symposium. Tarcza, G.A. (ed.), National Inst. of Radiation Protection, Stockholm, Sweden.

Bergman, C.: Boge, R.; Snihs, J.0. 1987. "Decommissioning policy in Sweden." In International decommissioning symposium. SSI-87-25; CONF-8710, National Inst. of Radiation Protection, Stockholm, Sweden.

Berman, M. 1986. "Message of Chernobyl." Resurgence 119:6-7.

Bernstein, J. 1988. Hans Bethe: Prophet of energy. Hirzel, Stuttgart, Germany, F.R.

Berry, H.A.; Burson, Z.G. 1987. "Developing a comprehensive and accountable data base after a radiological accident." In Radiological accidents, perspectives and emergency planning preparedness. EG\&G Énergy Measurements, Inc., Las Vegas, NV, U.S.A.

Berry, H.A.; Burson, Z.G. 1986. "Developing a comprehensive and accountable database after a radiological accident." In American Nuclear Society annual meeting. EG\&G Energy Measurements, Inc., Las Vegas, NV, U.S.A.

Berry, R.J. 1987. "Chernobyl - the anatomy of a disaster." Cancer Top. $6(4): 40-42$.

Berry, R.J. 1987. "Early radiation casualties - what Chernobyl has taught us." J. Soc. Radiol. Prot. 7(2):55-59.

Berteig, L. 1986. Activities, projects and emergency planning, etc. at the National Institute of Radiation Hygiene in connection with the Chernobyl reactor accident. Statens Inst. for Straalehygiene, OsTo, Norway.

Bethkenhagen, J. 1987. "Nuclear power progresses slowly in the COMECON. Nuclear policy in the USSR and Eastern Europe. "Energiewirtsch. Tagesfragen $37(10): 798-800$. 
Bewley, D.K.; Freemantle, C.J.A. 1986. Whole-body radioactivity measurements at Hammersmith Hospital. Haywood, J.K. (ed.), Institute of Physical Sciences in Medicine, London, U.K.

Bhabha Atomic Research Centre. 1986. Results of radioactive fallout measurements in India during May-June 1986. Bhabha Atomic Research Centre, Bombay, India.

Bhat, I.S.; Hegde, A.G.; Chandramouli, S.; Subbaratnam, T. 1987. "Radioiodine in the Tarapur environment due to Chernobyl reactor accident." Indian $\mathrm{J}$. Environ. Prot. 7(1):27-29.

Bhatti, M.S.; Ihsanullah; Shafiq, M.; Perveen, N.; Orfi, S.D. 1987. Chernobyl radioactivity and high altitude air-particulate monitoring at Islamabad. PINSTECH/HPD-135, Pakistan Inst. of Nuclear Science and Technology, Islamabad, Pakistan.

Bianco, A. 1986. "Role of International Atomic Energy Agency." In International conference on non-military radiation emergencies. DOE/ER/60525-1, IAEA, Vienna, Austria.

Bidwai, P. 1988. Getting out of the nuclear fix: towards an alternative model of development. Mackay, L.: Thompson, M. (eds.), Pluto Press, London, U.K.

Billen-Girmscheid, G. 1986. "Chernobyl and its consequences - no reason left to worry anymore." In Meeting on after the Chernobyl accident: how safe is our food?. CONF-8606412, Stiftung Verbraucherinstitut, Berlin, Germany, F.R.

Bindon, F.J.L. 1987. "Fire fighting at Chernobyl and fire protection at UK nuclear power stations." Nucl. Eng. 28(1):21-23.

Birkhofer, A. 1987. "Will the Chernobyl reactor accident have to be answered by changes. Nuclear power plant risk assessment in the Federal Republic of Germany." Energiewirtsch. Tagesfragen $37(4): 337-339$.

Birkhofer, A. 1987. "Safety of German nuclear power plants." ATW, Atomwirtsch. Atomtech. 32(10):474-480.

Biro, T.; Feher, 1.: Sztanyik, B.L. 1987. "Radiation consequences of the Chernobyl Nuclear Power Plant accident in Hungary." Energ. Atomtech. $40(4): 145-155$.

Biro, T.; Feher, I.; Sztanyik, B.L. 1987. "Radiation impacts of the Chernobyl reactor accident in Hungary. Summary report." Termesz. Vilaga 118(2):50-57.

Bischoff, W. 1988. "EC law on radiological protection - can it be made by immediately binding regulation." Unwelt-Planungsrecht 8(3):81-88. 
Bischoff, J.; Brunner, E.; Janssen, K.H.; Pokatzky, K.; Sontheimer, M.; Stock, U.; Thym, R.; et ai. 1986. "It can't go on like that. From Brokdorf to Wackersdorf: Will the revived resistance against atomic energy end in a dead circle of violence?" Zejt 41(25):25-29.

Bjurman, B.; Vintersved, I.; De Geer, L.E.; Arntsing, R.; Jakobsson, S. 1987. Detection in Sweden of short-lived fission products probably vented from the underground nuclear test at Novaya Zemlya on 2 August 1987. Foersvarets Forskningsanstalt, Stockholm, Sweden.

Blaauboer, R.0. 1986. Estimation of the radiation burden during stay abroad. Document 18. Rijksinstituut voor Volksgezondheid en Milieuhygiene, Bilthoven, Netherlands.

Blake, E.M.; Payne, J.; Vlajcic, P. 1986. "ANS in Reno: a look at the mature industry." Nucl. News 29(10):99-106.

Blix, H. 1987. "International cooperation in nuclear power development and nuclear safety. The post-Chernobyl IAEA perspective." Gensan Nenji Taikai Hobunshu $20: I / 3 / 1-I / 3 / 2$.

B]ix, H. 1987. "Nuclear power : environmental risks and energy production." Nuc1. Spectrum 3(2):14-19.

Blix, H. 1986. "Post-Chernobyl outlook for nuclear power. A view on responses to the accident from an international perspective." IAEA Bull. $28(3): 9-12$.

Blix, H. 1986. "Post-Chernobyl outlook for nuclear power." Nucl. Eng. $27(4): 131-135$.

Blix, H. 1986. "Nuclear energy after Chernobyl. Talk given at the ENC' 86 held in Geneva, June 1-6, 1986." Schweiz. Ver. Atomenerg., Bull.

$28(12): 24-30$.

Blix, H. 1987. "Present and future place of nuclear power in the world and its role in relation to environmental risks and energy production." In Managing environmental risks. INIS-mf-11235, IAEA, Vienna, Austria.

Blix, H. 1986. "Nuclear safety after Chernoby1." Nucl. Eur. 6(11):9-11.

Blomqvist, L; Paakkola, 0.: Suomela, M. 1987. Dose assessment. Chapter 5. STUK-A-55, Finnish Centre for Radiation and Nuclear Safety, Helsinki,

Finland.

Blowers, A.: Pepper, D. 1987. Nuclear power in crisis: Politics and planning for the nuclear state. Croom Helm Ltd., Beckenham, U.K.

Board of Accident Investigations. 1986. Post-Chernobyl emergency planning. Board of Accident Investigations, Stockholm, Sweden. 
Boccolini, A.; Gentili, A.; Guidi, P.; Sabbatini, V.; Toso, A. 1988. "Observation of silver-110m in the marine mollusc Pinna nobilis." J. Environ. Radioact. 6(2):191-193.

Bock, H.; Buchtela, K.; Grass, F.; Hammer, H.; Tschirf, E.; Tschurlovits, M.; Unfried, E.; . 1986. "Der Reaktorunfall von Tschernobyl und Seine Radiologischenfolgen fr Osterreich" In XIII IRPA Regional Congress. Atominstitut von Osterreichischen Universitten, Wien.

Boddy, K. 1986. "Chernobyl - the 'diary' of a regional medical physics department." Phys. Bu1]. 37(8):346-347.

Boddy, K.; Fenwick, J.D.; McKenzie, A.L.; Francis, R.A.; Richardson, M.A.; Smith, P.H.S. 1988. "Post-Chernobyl radjocaesium exposure in the UK." Lancet $1(8587): 705-706$.

Boddy, K.; Fenwick, J.D.; Sinclair, J.; Bartholomew, P.H.; Haywood, J.K. 1986. Chernoby 1: the response of a regional medical physics department. Institute of Physical Sciences in Medicine, London, U.K.

Bode, M.; Theile, F.W.; Metzner, R. 1987. "Fallout of the Chernobyl reactor accident; decontamination and nuclide spectra." In Annual meeting on nuclear technology. Deutsches Atomforum e.V., Bonn, Germany, F.R.

Boellmann, U.; Zeising, H. 1986. "Weather conditions in connection with the radioactive fallout and washout from the Chernobyl reactor accident." Gesund. -Ing. 107(5):266-273.

Bogen, J. 1987. "ENC ' 86 overshadowed by Chernobyl. Report about the joint ENC-4/Foratom IX conference in Geneva." ATW, Atomwirtsch., Atomtech. $32(1): 46-47$.

Bogner, L. 1986. "Whole-body and incorporation measurements on persons occupationally exposed to ionizing radiation." Gesund.-Ing. 107(5):306-308.

Bogner, L.; Muehle, P.; Czempie1, H. 1986. "Wholebody-counter measurements after the nuclear power plant accident of Chernobyl of different groups of people living in the area of Munich." Nuklearmediziner 9(5):365-373.

Bojcun, M. 1988. "USSR is changing its plans as quietly as possible." Energy Econ. 78:2-4.

Bommer, J.-P. 1987. "American passing through Switzerland." Rev. Polytech. $1: 26-27$.

Bominer, J.-P. 1986. "Give nuclear energy a chance exclamation." Electro-Rev. $78(25): 19-20$.

Bondietti, E.A.; Brantley, J.N. 1986. "Characteristics of Chernobyl radioactivity in Tennessee." Nature $322(6077): 313-314$. 
Bondietti, E.A.; Brantley, J.N.; Rangarajan, C. 1988. "Size distributions and growth of natura1 and Chernobyl-derived submicron aerosols in Tennessee." J. Environ. Radioact. 6(2):99-120.

Bone11, P.G. 1988. "Analys is of the RBMK against UK safety principles." In International approach to nuclear safety seminar. Ballard, G.M. (ed.), CONF-8806174, Elsevier Applied Science, London, U.K.

Bonelli, P.; Tronci, N.; Villone, B. 1987. "Study of the medium- and long-range transport analysing the data of the Chernobyl accident." Nuovo Cimento SoC. Ital. Fis. 10(3):265-283.

Bonka, H.; Horn, H.G.; Kueppers, J.; Maqua, M. 1986. "Radiological measurements and radiation exposure of the population of Aachen after the nuclear reactor accident at Chernobyl." Wiss. Umwelt ISU 1:39-50.

Bonka, H.; Kueppers, J.; Koesters, G.; Maqua, M. 1987. "Radiation exposure of the population of Aachen during the first year after the nuclear reactor accident at Chernobyl." Wiss. Umwelt ISU 3:154-166.

Bonte, F.J. 1988. "Chernobyl retrospective." Semin. Nuc1. Med. 18(1):16-24.

Boonekamp, P.G. 1986. Sensitivity analyses of electric power generation in energy models for The Netherlands, 1986. Stichting Energieonderzoek Centrum Nederland, Petten, Netherlands.

Borg, I.Y. 1987. Present and future nuclear power generation as a reflection of individual countries resources and objectives. Lawrence Livermore National Lab., Livermore, CA, U.S.A.

Borsch, P. 1986. "Results of recent safety analyses - GRS meeting 1986." Energiewirtsch. Tagesfragen 36(12):987-989.

Bosnjakovic, B.F.M. 1987. "Effusion and spreading of contamination caused by the reactor accident in Chernobyl. Chapter 5." In Chernobyl - report of the Dutch delegation. Van Loon, A.J. (ed.), KIVI-Kerntechniek, Arnhem, Netherlands.

Bosnjakovic, B.F.M. 1987. "Background of the government measures during the accident of Chernobyi." NVS-Nieuws 12(1):15-18.

Bourdillon, P.J. 1987. "Role of NHS hospitals in the preparedness for nuclear accidents." Br. J. Radiol. 60(720):1171-1174.

Bowlt, C. 1986. "Thyroid radiation dose in Britain arising from the Chernobyl accident." Lancet 2(8509):756.

Bowlt, C. 1987. "Measured human thyroid radioactivities in Britain arising from the Chernobyl disaster." J. Soc. Radiol. Prot. 7(3):129-135.

Braatz, U.; Dibbert, H.J. 1986. "Nuclear fuel supply - a status report." At. Stron 32(3): $92-95$. 
Brajnik, D.; Budnar, M.; Cindro, V.; Glavic, D.; Korun, M.; Staric, M.; Stegnar, P. 1986. "High resolution spectrometer for rapid monitoring of the thyroid dose caused by the Chernobyl accident." In 32. annual conference on bioassay, analytical and environmental chemistry. National Bureau of Standards, Gaithersburg, MD, U.S.A.

Brajnik, D.; Budnar, M.; Korun, M.; Likar, A.; Martincic, R.; Miklauzic, U.; Pucelj, B. 1986. "Early monitoring of the radioactivity in the NW of Yugoslavia after the Chernobyl accident." In 32. annual conference on bioassay, analytical and environmental chemistry. National Bureau of Standards, Gaithersburg, MD, U.S.A.

Brajnik, D.: Korun, M. 1988. "Levels of Pb-210 and other low energy photon emitters studied by a planar Ge(HP) spectrometer." Sci. Total Environ. 69:69.

Brajnik, D.; Korun, M.; Martinchich, R.; Pucelj, B. 1987. "Areas contamination in SR Slovenia after the Chernobyl accident." In 14. Yugoslav symposium on radiation protection. Yugoslav Radiological Protection Association, Novi Sad, Yugoslavia.

Brajnik, D.; Korun, M.; Martinchicj, R.; Pucelj, B. 1987. "Some interesting results after the Chernobyl accident." In 14. Yugoslav symposium on radiation protection. Yugoslav Radiological Protection Association, Novi Sad, Yugos Tavia.

Brajnik, D.; Martincic, R.; Puce1j, B. 1986. "Evaluation of the population dose received in the $N$ W of Yugoslavia during the Chernobyl accident." In 32. annual conference on bioassay, analytical and environmental chemistry. National Bureau of Standards, Gaithersburg, MD, U.S.A.

Braun, W.; Freiberger, S. 1986. "German reactor safety and the Chernobyl reactor accident." Siemens-Z. 60(6):20-25.

Bregeon, L. 1987. "Accident of Chernobylsk: chronology and causes." In SFEN meeting on Chernobyl accident: safety and environmental aspects. CEA Centre d'Etudes Nucleaires de Fontenay-aux-Roses, France.

Breuer, F.; Trenta, G. 1987. "Radiological consequences in Italy of the Chernoby 1 accident." Acqua Aria 10:1237-1243.

Brewer, K.N.; Burchfield, L.A. 1986. "Radioiodine plateout." In 32. annual conference on bioassay, analytical and environmental chemistry. National Bureau of Standards, Gaithersburg, MD, U.S.A.

Brigstock, D. 1987. "Lessons of Chernobyl." Biologist 34(3):150-152.

Brilliant, M.D.; Vorob'ev, A.I.; Gogin, E.E. 1987. "Late effects of low-dose ionizing radiation on man." Ter. Arkh. 59(6):3-8.

British Medical Association. 1987. Living with risk. The British Medical Association guide. John Wiley and Sons Inc., Chichester, U.K. 
British Nuclear Energy Society. 1987. "Chernobyl: a technical appraisal." In Chernobyl - a technical appraisal' seminar. British Nuclear Energy Society, London, U.K.

Brnovicj, R.; Vukoticj, M.; Mijatovicj, Lj.; Hajdukovicj, D. 1987. "Levels of radioactive contamination of food stuff on the territory of Serbia during the 1986 year after the Chernobyl accident." In 14. Yugoslav symposium on radiation protection. CONF-8706303, Yugoslav Radiological Protection Association, Novi Sad, Yugoslavia.

Brookhaven National Lab. 1986. "Workshop on short-term health effects of reactor accidents: Chernobyl." In Short-term effects of reactor accidents: Chernobyl. Brookhaven National Lab., Upton, NY, U.S.A.

Brunner, E.; Janssen, K.H. 1986. "Never ending burden: Germany in the year 1 past Chernobyl: Confused experts, distressed mothers, contaminated milk. Radiation doses went down, but the cancer risk and genetic hazards remain." Zeit $41(44): 33-37$.

Brunner, E.; Janssen, K.H.; Sontheimer, M. 1986. "Chernobyl: A series of mistakes." Zeit 41(43):17-21.

Brunner, G.; Schmidt, C. 1986. "Chernobyl and the international liability regime. Aspects of international private law and civil law in accordance with the law of the USSR." Versicherungsrecht $37(33): 833-843$.

Brunner, H. 1986. "EIR center's role in monitoring Chernobyl impact on Switzerland." Nucl. Eur. 6(11):38.

Brunner, H.H. 1986. "Swiss nuclear power plants: public protection." Tech. Rundsch. 78(51):40-51.

Brunner, P.; Bobleter, 0. 1986. "Nuclear reactor accident in Chernobyl and its consequences in Austria." Oesterr. Chem.-Z. 1986(6):186-192.

Bryukhanov, V.P. 1982. "Operation of NPPs with the RBMK-1000 reactors at power system perturbations." Teploenergetika 6:16-18.

Bucher, J. 1986. "Swiss power generation industry after Chernobyl." Bu11. Assoc. Suisse Electr. $77(12): 740-743$.

Bucher, J. 1986. "Presidential address to the General Assembly of the Association of Swiss Power Stations on 5th September 1986 in Montreux. "Bu11. Assoc. Suisse Electr. $77(20): 1270-1281$.

Bucina, I.; Dvorak, Z.; Malatova, I.; Ticha, H.; Drabova, D. 1988. "Radionuclides from the Chernobyl accident in soil over the Czechoslovak territory: their origin, deposition and distribution." In 20 . international symposium on radiation protection physics. INIS-mf-11311, Institut Hygieny a Epidemiologie, Prague, Czechoslovakia. 
Buechele, C. 1986. Facts against nuclear electricity generation. An analysis of the current situation. (2nd edition). Dreisam-Verl., Freiburg im Breisgau, Germany, F.R.

Bueno de Mesquita, K.G. 1987. "Possibility of the performance of a nuclear melt-down. Chapter 13." In How can the engineer minimize the risks of nuclear power plants?. Van Loon, A.J. (ed.), KIVI-Kerntechniek, Arnhem, Metherlands.

Buesseler, K.0.; Livingston, H.D.: Honjo, S.; Hay, B.J.; Manganini, S.J.; Degens, E. 1987. "Chernobyl radionuclides in a Black Sea sediment trap." Nature $329(6142): 825-828$.

Bujdoso, E. 1987. "Chernobyl reactor accident. A current bibliography." J. Radioanal. Nucl. Chem. 116(1):223-231.

Bundesant fuer Energiewirtschaft. 1986. Chernobyl accident: An overview of causes and effects. Bundesamt fuer Energiewirtschaft, Wuerenlingen, Switzerland.

Bundesforschungsanstalt fuer Landeskunde und Raumordnung. 1987. Topical data on regional environmental exposure. Environment II: Water and so $\overline{11 .}$. Bundesforschungsanstalt fuer Landeskunde und Raumordnung, Bonn, Germany, F.R.

Bundesministerium fuer Umwelt. 1986. Chernobyl reator accident and its consequences. Informative report prepared on behalf of the IAEA meeting, Vienna, August 25-29, 1986. Part. 1: General material. Part. 2: Appendix 1-7. Bundesministerium fuer Umwett, Bonn, Germany, F.R.

Bunne11, L.R.: Campbel1, T.K.; Tingey, G.L. 1987. "Oxidation of TSX graphite over the temperature range 450 to $1200 \mathrm{deg} C$." In 63. biennial carbon conference. Pacific Northwest Lab., Richland, WA, U.S.A.

Bunyard, P. 1986. "Nuclear power - the Hydra's head." Ecologist $16(6): 226-228$.

Bunzl, K. 1987. "Behaviour of radionuclides in soil." Dtsch. Tieraerztl. Wochenschr. $94(6): 357-359$.

Bunz 1, K.; Kracke, W.; Vorwohl, G. 1988. "Transfer of Chernobyl-derived Cs-134, Cs-137, I-131 and Ru-103 from flowers to honey and pollen." J. Environ. Radioact. 6(3):261-269.

Burch, A.; Owen, G.M.; Haywood, J.K. 1986. Monitoring of milk, water and personnel at the University Hospital of Wales, Cardiff. Institute of Physical Sciences in Medicine, London, U.K.

Burkart, K. 1988. "Nuclear power plant accident in Chernobyl - causes and consequences." Chem.-2tg. 112(6):181-190. 
Burtscher, A. 1986. "What one should know about radiation. Comparison of radiation burden from the Chernobyl accident and the atomic weapons test." Agro Zucker $4: 4$.

Bussac, J. 1987. "Closing address." In Conference on the science and technology of fast reactor safety. British Nuclear Energy Society, London, U.K.

Bussac, J. 1988. "Need for further nuclear safety research: A present French view." Nucl. Eng. Des. 108(1/2):1-5.

Busuoli, G. 1987. "Radjological consequences of the Chernobyl accident for Italy." Radiat. Prot. Dosim. 19(4):247-251.

Butenschoen, M.; Hoffmann, W.; Hanke, T.; Ulrich, 0. 1987. "Ghost has left the bottle: One year after Chernobyl." Zeit 42(18):37-40.

Buttermann, G. 1988. Schiwy - Precautionary radiation protection laws. Collection of the entire Federal German laws by the government and the Land governments. Commentary. 1st supplement. Radioactivity and radiation. Chernobyl - medicine - technology. Schulz, Percha, Germany, F.R.

Butz, H.P.; May, H. 1987. "Chernobyl - one year after. Radiation protection and the issue of safety in Germany." Energie 39(4):40-46.

Byrne, A.R. 1988. "Radioactivity in fungi in Slovenia, Yugoslavia, following the Chernobyl accident." J. Environ. Radioact. 6(2):177-183.

C. Brofferio. 1986. "Radiological Situation in Italy Following the Chernobyl Accident" In CRECA Meeting. Schulz, Percha, Germany, F.R.

CEA Centre d'Etudes Nucleaires de Fontenay-aux-Roses. 1986. Estimation of Public Health consequences of Chernobyl nuclear accident (26 April 1986) based on CEA centers measurements. CEA Centre d'Etudes Nucleaires de Fontenay-aux-Roses, France.

CEA Centre d'Etudes Nucleaires de Fontenay-aux-Roses. 1986. Chernobyl accident. CEA Centre d'Etudes Nucleaires de Fontenay-aux-Roses, France.

CEA Centre d'Etudes Nucleaires de Saclay. 1986. Impact of fallout from Chernobyl on Saclay site. CEA Centre d'Etudes Nucleaires de Saclay, Gif-sur-Yvette, France.

CSN. 1986. Informe sobre las consecuencias radiologicas en Espana del accidente de la C.N. de Chernobyl Consejo de Seguridad Nuclear (CSN), Madrid, Spain.

Cagnetti, P. 1987. "Diffusion and deposition of radioactive airborne particulates following the Chernobyl accident." In Conference AIRP sull' incidente di Chernobyl. Ass. It. Protezione Contro le Radiazioni, Bologna, Italy. 
Caldwel1, L.S. 1986. "Chernobyl and the credit markets." Nucl. News $29(10): 44-45$.

Cambray, R.S.; Cawse, P.A.; Garland, J.A.; Gibson, J.A.B.; Johnson, P.; Lewis, G.N.J. 1987. "Observations on radioactivity from the Chernoby] accident." Nucl. Energy 26(2):77-101.

Cambray, R.S.; Cawse, P.A.; Garland, J.A.; Gibson, J.A.B.: Johnson, P.: Lewis, G.N.J.; Newton, D. 1987. "Observations on Radioactivity from the Chernobyl Accident" Nuclear Energy 26(2):77-101.

Cambray, R.S.; Playford, K.; Lewis, G.N.J.; Burton, P.J. 1987. Radioactive fallout in air and rain. Results for 1985 and 1986. AERE-R-12872, UKAEA Harwe]l Lab., U.K.

Camplin, W.C.; Mitche11, N.T.; Leonard, D.R.P.; Jefferies, D.F. 1986. Radioactivity in surface and coastal waters of the British Isles. Monitoring of fallout from the Chernobyl reactor accident. Ministry of Agriculture, Fisheries and Food, Lowesoft, U.K.

Cannell, W. 1986. "Chernobyl, Challenger and the numbers game." Financ. Times Energy Econ. 59:2-4.

Cap, F. 1987. "Impacts of the Chernobyl accident on Austria's economy." 0esterr. Z. Elektrizitaetswirtsch. 40(4):134-135.

Cap, F. 1986. "What happened at Chernobyl?" Oesterr. Z. Elektrizitaetswirtsch. 39(6):89-93.

Capra, D.; Facchini, U.; Gianelle, V.; Ravasini, G.; Ravera, 0.; Pizzala, A.; Bacci, P. 1987. "Chernobyl accident. The radioactive contamination in the area of Lake Como and in other Northern Italy sites. "Nuovo Cimento Soc. Ital. Fis. 10(3):285-313.

Capra, D.; Facchini, U.; Gianelle, V.; Ravasini, G.; Ravera, 0.; Volta, L.; Pizzola, A. 1988. "Chernobyl accident. The ground deposition of radionuclides in Padana plain and in Alps Valleys and the radioactive contamination of the Como lake." Acqua Aria n.3:305-318.

Carbol, P.; Salberg, M.; Ittner, T. 1987. "Radionuclide migration and radionuclide mass balance calculations of the Chernobyl fallout in Sweden." In International conference on chemistry and migration behavior of actinides and fission products in the geosphere. CoNf-870965, Technische Univ., Garching, Germany, F.R.

Carbonaro, V.; Cigna, A.A.; Cortissone, C.; Giacomelli, R.; Pirastru, E.; Spezzano, P. 1987. Post Chernobyl-5. Radiometric and radiotoxicological checks. ENEA, Rome, Italy.

Carcassi, M.; Carnasciali, F.; Fineschi, F. 1987. "Hydrogen control systems in nuclear light water reactors." Tec. Ita1. 52(1):1-10. 
Carillo, D.: Diaz de la Cruz, F.; Ruiz del Arbol, E. 1987. "Information and training programs in Spain's nuclear emergency plan program." Nucl. Eur. $7(6-7): 41$.

Carle, R. 1987. "Nuclear energy in Europe after Chernoby1." In 49. annual American power conference. Illinois Institute of Technology, Chicago, IL, U.S.A.

Carle, R. 1988. "French nuclear power programme and energy policy in France." Kernenergie $31(3): 88-94$.

Carmichael, R.J. 1988. "Chernobyl: the lessons learnt." J. R. Nav. Med. Serv. $74(1): 11-17$.

Carny, P.; Moravek, J.; Lieskovsky, M.; Sujak, P.; Stredova, A. 1988. "Long-term monitoring of environmental doses by thermoluminescent dosimetry." Jad. Energ. 34(3):93-97.

Caro, R. 1986. "ENS president's thoughts on Chernobyl." Nucl. Eur. 6(6):29.

Carpenter, E. 1988. "Visit to Chernobyl." Atom 377:22-23, 25.

Carr, K.R. 1987. "Expert systems for protective monitoring of facilities." In Instrument Society of America international conference and exhibit. Martin Marietta Energy Systems, Paducah, KY, U.S.A.

Carter, M. 1988. "She says no exclamation." Env. Now 9:14-15.

Castronovo, F.P. Jr. 1987. "Iodine-131 thyroid uptake results in travelers returning from Europe after the Chernobyl accident." J. Nucl. Med. 4:535-541.

Catlin, R.J.; Goldman, M.; Anspaugh, L.R. 1987. "Projected global health impacts from severe nuclear accidents: Conversion of projected doses to risks on a global scale: Experience from Chernobyl releases." In International conference on the technical and economic performance of nuclear power. Electric Power Research Inst., Palo Alto, CA, U.S.A.

Central Electricity Generating Board. 1986. Chernobyl. Central Electricity Generating Board, London, U.K.

Ceskoslovenska Akademie Ved. 1987. "Abstracts of submitted papers. VIIth national symposium on radiation dosimetry." In 7 . national symposium on radiation dosimetry. INIS-mf-11264, Ceskoslovenska Akademie Ved., Prague, Czechoslovakia.

Chalus, Z.; Sochor, R. 1987. "Chernobyl nuclear power plant accident." Stavby Jadrovej Energ. 1:11-14.

Chamberlain, A.C. 1987. Comparisons of the emissions in the Windscale and Chernobyl accidents. UKAEA Atomic Energy Research Establishment, U.K. 
Chan, P.W.W.; Dastur, A.R.; Grant, S.D.; Hopwood, J.M. 1988. "Chernobyl and pump cavitation." Nucl. Eng. Int. 33(409):16.

Changshou, Z.; Guilan, Z.; Jinding, Z; Ronglin, C. 1987. "Radioactive contamination levels in China and health evaluation following radioactive release from Soviet Chernobyl Nuclear Power Plant accident." Zhonghua Fangshe Yixue Yu Fanghu Zazhi 7(Supp1.):1-7.

Charles, J. 1987. "Chernobyl and the safety of the PWR NSSS design." Nucl. Eng. 28(4):119-120.

Chernyshenko, V.M. 1984. "Main results of the Chernobylsk NPP construction." Energ. Stroit. 11:2-6.

Chiecchio, A.; Bo, A.: Manzone, P.; Sala, S.; Barboni, G.; Scassa, R.; Caruso, G.: Luria, S. 1987. "Chernobyl's accident. Evaluation of the dose absorbed by thyroid of children of a Piedmont Valley by a measure of I-13I uptake." Radiol. Med. 74(4):316-320.

Chieco, N.A.: Zamichieli, M. (eds.). 1987. Environmental Measurements Laboratory annual report, 1986. USDOE Environmental Measurements Lab., New York, NY, li.S.A.

Chino, M.; Ishikawa, H.; Yamazawa, H.; Moriuchi, S. 1986. Application of the SPEEDI system to the Chernobyl reactor accident. Japan Atomic Energy Research Inst., Tokyo, Japan.

Chung, C.; Lo, J.G. 1986. "Radioactive iodine-131 over Taiwan after the Chernobyl accident." J. Radioanal. Nucl. Chem. 105(6):325-333.

Cigna, A. 1987. "Radioactivity measurement taken after Chernobyl." In Conference AIRP sull'incidente di Chernobyl. Ass. It. Protezione Contro le Radiazioni, Bologna, 1taly.

Cigna, A.A. 1987. "Environment and radiation protection in relation to nuclear accidents." Acqua Aria 10:1207-1216.

Cigna, A.A.; Dominici, G.; Spezzano, P. 1987. "Environmental radioactivity measurements after the Chernobyl accidents." Acqua Aria 10:1219-1225.

Cirla, A.; Ostinelli, A.; Zingales, A. 1987. "Evaluation of the dose equivalent absorbed by the population of Como and its interland as a consequence of the accident to the nuclear reactor of Chernobyl. "Radiol. Med. $74(6): 563-566$.

Clark, M.J. 1986. "Cloud from Chernobyl." New Sci. 112(1530):68.

Clark, M.J. 1986. "Fallout from Chernobyl." J. Soc. Radiol. Prot. $6(4): 157-166$.

Clark, M.J.; Smith, F.B. 1988. "Wet and dry deposition of Chernobyl releases." Nature 332(6161):245-249. 
Clarke, R.H. 1987. "Dose distributions in Western Europe following Chernobyl." In International conference on the biological effects of ionizing radiation. Jones, R.R.; Southwood, R. (eds.), CONF-8611250, John Wiley and Sons Inc., Chichester, U.K.

Clarke, R.H. 1986. "Chernobyl and the international agencies." Radiol. Prot. Bu11. 75:10-12.

Clarke, R.H. 1986. "NRPB response to Chernobyl." Radiol. Prot. Bull. 75:5-7.

Clarke, R.H. 1986. "Radiological aspects of Chernobyl in Western Europe." Soc. Radiol. Prot. 6(3):139-141.

Clarke, R.H. 1987. "Reactor accidents in perspective." Br. J. Radiol. $60(720): 1182-1188$.

Clemente, M.; Frisch, W.: Langenbuch, S.; Weber, J.P. 1986. Analys is and first evaluation of the course of the Chernobyl accident up to the excursion. Interim report. Bundesministerium fuer Umwelt, Bonn, Germany, F.R.

Clint, G.M. 1988. "Agricultural research after Chernobyl." Radiol. Prot. Bull. 95:13-15.

Clough, P.N. 1987. "Chernobyl accident - source terms and related characteristics." In Chernobyl - a technical appraisal' seminar. British Nuclear Energy Society, London, U.K.

Clough, P.N. 1988. "Source terms and the Chernobyl accident." In International approach to nuclear safety seminar. Ballard, G.M. (ed.), CONF-8806174, Elsevier Applied Science, London, U.K.

Cohen, B.L. 1987. "Nuclear reactor accident at Chernobyl, USSR." Am. J. Phys. $55(12): 1076-1083$.

Colacino, M.; Dietrich, E.: Favale, B.; Passamonti, V. 1987. "Chernobyl accident: Measurement of atmospheric radioactivity in Italy." In Conference AIRP sull'incidente di Chernobyl. CONF-8606400, Ass. It. Protezione Contro le Radiazioni, Bologna, Italy.

Colacino, M.; Favale, B.; Passamonti, V.; Baldi, M.; Dietrich, E. 1986. Chernobylsk accident: radioactivity measurement of airborn particulate in the AM/CNR network. CNR-IFA-86-38, Consiglio Nazionale delle Ricerche, Rome, Italy.

Colacino, M.; Favale, B.; Passamonti, V.; Baldi, M.; Dietrich, E. 1987. "Chernobyl accident. Air radioactivity measurements in Italy." Nuovo Cimento Soc. Ital. Fis. 10(3):249-264.

Collier, J. 1987. "1986/87 - a profitable year." Atom 372:24-25. 
Collier, J.G.: Davies, L.M. 1986. Chernobyl. Central Electricity Generating Board, Barnwood, U.K.

Collins, H.E.: Emmerson, B.W.; Havinh P. 1986. "Information exchange and mutual emergency assistance. The framework for accident response and notification." IAEA Bul]. 28(3):16-17.

Colomb, A. 1986. "High technology - a pillar of our culture." Schweiz. Ver. Atomenerg., Bul1. 28(15):23-26.

Compes, P.C. 1987. "Management of accident risks." In AGF congress on Chernobyl and the future of energy supply in the Federal Republic of Germany. Wuppertal Univ., Gesamthochschule, Germany, F.R.

Comtois, W.H. 1986. "Impact of the Soviet nuclear disaster at Chernobyl on energy planning." In International conference on the development of alternative energy sources and the lessons learned since the oil embargo. Saluja, S.S. (ed.), Westinghouse Electric Corp., Pittsburgh, PA, U.S.A.

Connolly, J. 1986. "Examination of the accident to the Chernobyl-4 reactor." Nuc]. Aust. $3(5): 2-4$.

Connol1y, J.W. 1987. "Chernobyl accident." Aust. Phys. 24(3):60-63.

Conway, A. 1987. "Uranium $v$ the rest." Mod. Power Syst. $7(12): 35,37,39$.

Conway, A, 1987. "Wise men's lessons from Chernoby1." Atom 372:14-16.

Cook, I. 1988. "Assessment of large-scale, in-vessel, stean explosions." In International approach to nuclear safety seminar. Ballard, G.M. (ed.), CONF-8806174, Elsevier Applied Science, London, U.K.

Cook, J. 1986. Red a lert. The worldwide dangers of nuclear power. New English Library, Sevenoaks, U.K.

Coordinatie-Commissie voor de Metingen van Radioactiviteit en Xenobiotische. 1986. Radioactive contamination in the Netherlands caused by the nuclear reactor accident at Chernobyl. Coordinatie-Comissie voor de Metingen van Radioactiviteit en Xenobiotische, Netherlands.

Corbett, J. 1987. "Safety of nuclear power in a risky world." Atom 368:20-21, 23.

Corbyn, J.: Banks, T.; Goodlad, A. 1986. "Nuclear power stations (safety)." Hansard, House Commons Off. Rep. 98(120):342-347.

Corfield, J.R.; Mountford, P.J.; Hells, C.P.; Haywood, J.K. 1986. Chernobyl activity at Canterbury. Institute of Physical Sciences in Medicine, London, U.K. 
Cortissone, C.; Giacomelli, R.; Spezzano, P.; Porzio, L. 1987. "External dose and effective dose equivalent committed for Piedmont population from 20 April 1986 through 22 September 1987." Acqua Aria 10:1227-1236.

Cortissone, C.; Giacomelli, R.; Spezzano, P.; Porzio, L. 1988. Total external dose equivalent and effective dose derived to the Piedmont population in the period 30 Apr 1986 - 22 Sep 1987. ENEA-RT-COMB-88-1, ENEA, Rome, Italy.

Cottens, E. 1986. "Contamination levels observed on the Belgian territory subsequent to the Chernobyl accident." In Seminar on the Chernobyl accident and its impact. Institut d'Hygiene et d'Epidemiologie, Brussels, Belgium.

Country Landowners Association. 1987. North Wales Group report on the effects of the Chernobyl accident. Country Landowners Association, London, U.K.

Crace, J. 1987. "Chernobyl comes to paradise." Sunday Times Mag. p. 22-25, 27-29.

Crestana, S.; Zimmerman, R.L. 1987. "Measures of Chernobyl isotopes in imported milk." Cienc. Cult. 39(7):52.

Croll, D.0. 1986. "High cost of nuclear phase-out." Pet. Econ. $53(12): 448-449$.

Cross, M. 1986. "Nuclear Sweden's final meltdown." New Sci. 110(1509):34-36.

Cruickshank, A.; Masters, R. 1986. "Latest five year plan confirms Soviet ambitions." Nucl. Eng. Int. 31(385):25.

Csongor, E.; Kiss, A.Z.; Nyako, B.M.; Somorjai, E. 1986. "Chernobyl fallout in Debrecen, Hungary." Nature 324(6094):216.

Cuddihy, R.G.; Finch, G.L.; Newton, G.J.; Hahn, F.F.; Mewhinney, J.A.; Rothenberg, S.J. 1986. Characteristics of radioactive particles released from the Chernobyl nuclear reactor. Inhalation Toxicology Research Inst., Albuquerque, NM, U.S.A.

Cunningham, J. and MacNei11, G. 1987. "Chernobyl--Its Effects on Ireland" In Workshop on the Radiological Consequences of Chernobyl, Commission of European Communities. Nuclear Energy Board, Dublin.

Cunningham, J.D.: MacNeill, G.; Pollard, D. 1987. Chernobyl its effect on Ireland. INIS-mf-11216, Nuclear Energy Board, Dublin, Ireland.

Curdt, W. 1986. "Nuclear spectroscopy analysis of grass specimens after the Chernobyl reactor accident." Prax. Naturwiss., Phys. 35(7):39-42.

Czakainski, M. 1986. "Nuclear energy in developing and transitional economies - from the outset until Chernobyl." Glueckauf 122(20):1355-1362.

Czakainski, M. 1987. "Nuclear energy worldwide. One year after the Chernobyl reactor accjont." Energiewirtsch. Tagesfragen $37(4): 342$. 
Czakainski, M. 1986. "Chernobyl reactor accident - provisional results and consequences." Z. Energiewirtsch. 10(2):153-161.

Czeizel, E.; Billege, B. 1988. "Teratological evaluation of pregnancy outcomes in Hungary after the Chernobyl reactor accident." Orv. Heti1. $129(9): 457-462$.

Dace, M. 1987. Everything you wanted to know about radiation and health (but couldn't find anyone to ask). Medical Campaign Against Nuclear Weapons, London, U.K.

Daglish, J. 1987. "IAEA in 1986." Atom 363:16-17.

Daglish, J. 1986. "Human fallibility: still the weak link in nuclear safety." Nucl. Eng. Int. $31(386): 25-26$.

Daglish, J. 1988. "Radiophobia and radiation protection." Atom 383:14-17.

Daglish, J.; Gittus, J. 1986. "Chernobyl and after." Atom 360:6-8.

Dallibor, K. 1987. "Chernobyl and the consequences for the Federal Republic of Germany." In AGF congress on Chernobyl and the future of energy supply in the Federal Republic of Germany. Arbeitsgemeinschaft der

Grossforschungseinrichtungen ( $\overline{A G F}$ ), Bonn, Germany, F.R.

Danali-Cotsaki, S.; Liritzis, Y. 1988. "Radiation dose assessment for Cs-137 from fish in the Aegean Sea before and after the Chernobyl accident." $\mathrm{J}$. Radioana T. Nucl. Chem. 126(3):257-266.

Davids, J.A.G. 1987. "Radioactivity and radiation hygienic standards. Chapter 8." In Chernobyl - environment and health aspects. Van Loon, A.J. (ed.), KIVI-Kerntechniek, Arnhem, Netherlands.

Davids, J.A.G.; Van Weers, A.W. 1986. "Radioactivity levels at ECN (Netherlands) after the Chernobyl reactor accident." Energiespectrum $10(6-7): 140-150$.

Davidson, C.I.: Harrington, J.R.; Stephenson, M.J.: Monaghan, M.C.; Pudykiewicz, J.; Schel1, W.R. 1987. "Radioactive cesium from the Chernobyl accident in the Greenland Ice Sheet." Science 237(4815):633-634.

Davidson; Bruce; Ezra. 1987. "Sizewell B Power Station." Hansard, House Lords. Off. Rep. 485(55):1157-1167.

Davis, D.S.: Dewolf, G.B.; Quass, J.D.: Wert, K.P. 1987. Prevention reference manual: chemical specific. Volume 2. Control of accidental releases of chlorine (SCAOMD) (South Coast Air Quality Management District). Final report, May 1986-March 1987. Radian Corp., Austin, TX, U.S.A. 
Davis, W.E.; 01sen, A.R.; Didier, B.T. 1988. "MLAM assessment of radionuclide air concentration and deposition for the Chernobyl reactor accident." In 17. NATO/CCMS international technical meeting on air pollution modelling and its application. PNL-SA-15336, Pacific Northwest Lab., Richland, WA, U.S.A.

De Bacci, M.; Fasoli-Stella, P.; Finzi, S.; Holtbecker, H. 1988. "Views of the Commission of the European Communities on nuclear plant safety after Chernobyl and its research activities." In International conference on nuclear power performance and safety. CONF-8709263, IAEA, Vienna, Austria.

De Crescenzo, S.; Tosi, G.; Giacomelli, M. 1986. "Incident from Chernobyl. Dosimetric evaluations and risk assessment." Radiol. Med. 72(10):699-704.

De Haas, J.В.M. 1986. "Nuclear reactors of Chernoby1." Energiespectrum $10(6-7): 122-128$.

De La Paz, L.R. 1986. "Proposed warning scheme for Philippine communities in case of severe radiological accidents in neighbor countries." In Meeting of action officers of the National Disaster Coordinating Council. Philippine Atomic Energy Comission, Diliman, Quezon City.

De La Paz, L.R.; Estacio, J.; Palattao, M.V.; Anden, A. 1986. Study of man made radioactivity baseline in dietary materials. Philippine Atomic Energy Commission, Diliman, Quezon City.

De La Paz, L.R.; Palattao, M.V.; Estacio, J.F.L.; Anden, A. 1987. Some radioactivity concentrations and ingestion dose projections arising from consumption of food containing Chernobyl contamination. PRRI(C)-II-A-87008, Philippine Nuctear Research Inst., Diliman, Quezon City.

De 0liveira, A.R. 1987. "Medical features of the radiological accident in Chernoby1." Rev. Imagem 2D(4):210-216.

De Paoli, L. 1987. "Italian energy policy." Sapere 53(9-10):25-31.

De Ruig, W.G. 1986. "Assessment of the effects of the Chernobyl accident in The Netherlands." Voedingsmiddelen Technol. 19(15):19-22.

De Ruig, W.G. 1986. Measurement of radioactive contamination of grass and milk (and a number of other articles of food) otherwise than by the Dutch Department of Agriculture and Fishery and the Dutch National Food Inspection Service. Document 12. Rijkskwaliteitsinstituut voor Land- en Tuinbouwprodukten (RIKILT), Wageningen, Netherlands.

DeBusk, R.E.; Walker, J.A. 1986. "Chernobyl nuclear accident and its consequences in Greece - Report No. 2." In Radiological accidents, perspectives and emergency planning preparedness. National Research Centre for the Physical Sciences Democritos, Athens, Greece.

Debauche, A. 1988. "Radiation monitoring of the surroundings of Chooz-Tihange-F leurus. Results 1986/1987." Rev. IRE 12(2):41-45. 
Debenham, A.A. 1988. "Development of probabilistic safety

criteria/principles." In International approach to nuclear safety seminar.

Ballard, G.M. (ed.), CONF-8806174, Elsevier Applied Science, London, U.K.

Debenham, A.A. 1988. "Review of Sizewell design safety features." In

International approach to nuclear safety seminar. Ballard, G.M. (ed.),

CONF-8806174, Elsevier Applied Science, London, U.K.

Debertin, K.; Kolb, W.; Lauterbach, U.; Pessara, W. 1987. Environmental radioactivity - problems in activity measurements. PhysikaTisch-Technische Bundesanstalt, Braunschweig, Germany, F.R.

De Leeuw, F.A.A.M.; Van Aalst, R.M.; Rheineck Leyssius, H.J. van; Kesseboom, H.; Egmond, N.D. van. 1986. Transport of radionuclides effused from Chernobyl over Europe. Document 2. Rijksinstituut voor Volksgezondheid en

Milieuhygiene, Bilthoven, Netherlands.

Democritos Nuclear Research Center. 1986. Consequences of the Chernobyl nuclear accident in Greece. Denocritos Nuclear Research Center, Athens, Greece.

Dendy, P.P.; Massoumi, R.; Palmer, K.E.; Szaz, K.F. 1986. Whole body monitoring in Cambridge. Haywood, J.K. (ed.). Institute of Physical Sciences in Medicine, London, U.K.

Dennis, J.A. 1986. "Measures and risks of radiation." Biologist $33(4): 195-197$

Denschlag, H.0.; Diel, A.; Glaesel, K.H.; Heimann, R.; Kaffrell, N.; Knitz, U.; Menke, H.; et al. 1987. "Fallout in the Mainz area from the Chernobyl reactor accident." Radiochim. Acta 41(4):163-172.

Denton, H.R. 1987. "Causes and consequences of the Chernobyl nuclear accident and implications for the regulation of U.S. nuclear power plants." Ann. Nucl. Energy $14(6): 295-315$.

Department of the Environment. 1986. Levels of radioactivity in the UK from the accident at Chernobyl, USSR on 26 April 1986. A compilation of the results of environmental measurements in the UK. H.M. Stationary office, London, U.K.

Depledge, M.H. 1986. "Global implications of Chernobyl." Mar. Pollut. Bull. $17(7): 281-282$.

Desmet, G.; Myttenaere, C. 1988. "Considerations on the role of natural ecosystems in the eventual contamination of man and his environment. "J. Environ. Radioact. 6(3):197-202.

Despres, J. 1987. Intelligence and the prevention of nuclear terrorism. Leventhal, P.: Alexander, Y. (eds.), Lexington Books, Lexington, MA, U.S.A. 
Deubner, S.; Iwatschenko-Borho, M.; Malzer, S.; Plank, H.; Schmitzer, R.; Giesse, E. 1986. Effects of Chernobyl on Mittelfranken. An evaluation of Erlangen and the surrounding regions. Erlangen-Nuernberg Univ., Erlangen, Germany, F.R.

Deutsche Welle, Auslandsfunk der Bundesrepublik Deutschland. 1986. Chernobyl reactor accident. A documentation submitted by the Deutsche Welle radio station. Deutsche Welle, Aus landsfunk der Bundesrepublik Deutschland, Koeln, Germany, F.R.

Deutsches Atomforum e.V. 1987. "Annual meeting on nuclear technology ' 87. Technical session on atmospheric spreading processes." In Annual meeting on nuclear technology. CONF-870602, Deutsches Atomforum e.V., Bonn, Germany, F.R.

Devel1, L.; Aarkrog, A.; Blomqvist, L.; Magnusson, S.; Treten, U. 1986. "How the fallout from Chernobyl was detected and measured in the Nordic countries." Nucl. Eur. 6(11):16-17.

Deve11, L.; Tovedal, H.; Bergstroem, U.; Appelgren, A.; Chyssler, J.; Andersson, L. 1986. "Initial observations of fallout from the reactor accident at Chernobyl." Nature 321 (6067):192-193.

Devell, L.; Tovedal, H.; Bergstroem, W. 1986. "Chernobyl fallout: corrigendum." Nature 321 (6071):643.

Devine, J. (ed.). 1986. Chernobyl: before and after. Information sheet No. 1. Institution of Mechanical Engineers, London, U.K.

Deworm, J.P.: Fieuw, G.: Govaerts, P.: and Zeevaert, Th. 1986. Evaluation of Doses Received by Members of the Belgian Population Due to the Chernobyl Reactor Accident Radiation Control and Safety Department, S.C.K./C.E.N., Mol.

Dibb, J.E.; Rice, D.L. 1988. "Chernobyl fallout in the Chesapeake Bay region." J. Environ. Radioact. $7(2): 193-196$.

Dibdin, T. 1987. "Radiological protection." SCRAM: Anti-NucT. Safe Energy J. p. 14 .

Dibdin, T. 1987. "Chernobyl and the media." SCRAM: Anti-NuCl. Safe Energy J. $61: 9$.

Dickerson, M.H.; Knox, J.B. 1987. "ARAC: a centralized computer-assisted energency planning, response, and assessment system for atmospheric releases of toxic material." In Radiological accidents, perspectives and emergency planning preparedness, Lawrence Livermore National Lab., Livermore, CA, U.S.A.

Dickerson, M.H.; Sullivan, T.J. 1986, ARAC response to the Chernobyl reactor accident. Lawrence Livermore National Lab., Livermore, CA, U.S.A. 
Dickerson, M.H.; Sullivan, T.J. 1988. "The atmospheric release advisory capability (ARAC): A federal emergency response capability." In 81 . annual meeting of Air Pollution Control Association. UCRL-98435, Lawrence Livermore National Lab., Livermore, CA, U.S.A.

Dieh1, J.F. 1986. "Chernobyl and its effects in terms of food contamination." In Annual meeting of Bund fuer Lebensmitteirecht und Lebensmittelkunde e.V. Bund fuer Lebensmittelrecht und Lebensmittelkunde e.V., Bonn, Germany, F.R.

Dieh1, J.F. 1986. "Radioactivity in foods - a status report." Aktuelle Ernaehr. Med. 11:11.

Diehl, J.F.; Ehlermann, D.; Frindik, 0.; Kalus, W.; Mueller, H.; Wagner, A. 1986. Radioactivity in foods - Chernobyl and the consequences.

Bundes forschungsanstalt fuer Ernaehrung, Karlsruhe, Germany, F.R.

Die1, F.; Meier-Ploeger, A, 1986. Reactor catastrophe in Chernobyl and the consequences in the area of Eastern Hesse. Fachhochschule, Fulda, Germany, F.R.

Dietrich, P. 1986. "Reactor accident of Chernobyl and its consequences." ETZ, Elektrotech. Z. $107(20): 954-956$.

Dilloo, R.: Thomas, R. 1986. Atomic technology - a dispute with the subnature. With an extensive discussion of the Chernobyl reactor accident. Verein fuer ein erweitertes Heilwesen, Bad Liebenzell, Germany, F.R.

Djuricj, G.: Popovicj, D.; Petrovicj, B. 1987. "Contents of some radionuclides in meat." In 14. Yugoslav symposium on radiation protection. CONF-8706303, Yugoslav Radiological Protection Association, Novi Sad, Yugoslavia.

Doerfel, H.; Fessler, H.; Hempelmann, S.; Koenig, L.A.; Schuettelkopf, H.: Wicke, A. 1987. "Radiation exposure of the public in the Karlsruhe area due to the Chernobyl accident." KFK-Nachr. 19(1):50-63.

Doerfel, H.; Piesch, E. 1987. "Radiological consequences in the Federal Republic of Germany of the Chernobyl reactor accident." Radiat. Prot. Dosim. $19(4): 223-234$.

Doerr, H.: Muennich, K.0. 1987. "Spatial distribution of soil: Cs-137 and Cs-134 in West Germany after Chernobyl." Naturwissenschaften 74(5):249-251.

Domingo, J.L.; Llobet, J.M.; Tomas, J.M.; Corbella, J. 1987. "Acute toxicity of uranium in rats and mice." Bul1. Environ. Contam. Toxicol. 39(1):168-174.

Dominici, G. 1987. "Following the Chernobyl accident, the first evaluation of environmental radiological impact for the zone, Ispra, Italy." In Conference AIRP sulf'incidente di Chernobyl. Ass. It. Protezione Contro le Radiazioni, Bologna, Italy. 
Donahue, M.; Gardner, R.; Vine, G. 1987. "Assessment of the Chernobyl-4 accident localization system." Nucl. Saf. 28(3):297-311.

Dorner, W.G. 1986. "Nuclear energy after Chernobyl." Tech. Rundsch. $78(41): 108-125$.

Oreicer, M.; Helfer, I.K.; Miller, K.M. 1986. Measurement of Chernobyl fallout activity in grass and soil at Chester, New Jersey. Volchok, H.L.; Chieco, N. (eds.), Lawrence Livermore National Lab., Livermore, CA, U.S.A.

Dreisigacker, E. 1986. "Chernobyl reactor accident: Comparison of fallout at three locations." Phys. Bull. 42(6):164.

Drepper, H. 1987. "Treatment of skin damage due to irradiation and post-irradiation skin tumours, at the Hornheide special clinic." In 27. annual conference of Vereinigung Deutscher Strahlenschutzaerzte e.v. Schuetz, J.; Boerner, W.; Messerschmidt, 0. (eds.), CONF-8605338, Thieme, Stuttgart, Germany, F.R.

Dubois, A.; Walker, R.I. 1988. "Prospects for management of gastrointestinal injury associated with the acute radiation syndrome." Gastroenterology 95(2):500-507.

Duco, J.; L'Homme, A.; Queniart, D. 1988. "Accident response in France." In International approach to nuclear safety seminar. Ballard, G.M. (ed.). CONF-8806174, Elsevier Applied Science, London, U.K.

Duftschmid, K.; Mueck, K.; Steger, F.; Vychytil, P.; Zechner, J. 1987. "Exposure of the Austrian population due to the Chernobyl accident." Radiat. Prot. Dosim. 19(4):213-222.

Dunster, H.J. 1986. "Chernobyl: as viewed by NRPB." Phys. Bul1. $37(8): 347$.

Dunster, J. 1986. "How we reacted to Chernobyl." New Sci. 110(1511):62-63.

Dupuis, M.C. 1986. "Scenario of the accident of Chernobyl. Technical aspects and safety." In 14. ATSR symposium on radiation protection problems encountered in major developments in new techniques and technologies. CEA Centre d'Etudes Nucleaires de Fontenay-aux-Roses, France.

Dycker, E. de. 1986. "Survey of the meteorological conditions during the first two weeks following the Chernobyl accident." In Seminar on the Chernobyl accident and its impact. Institut Royal Meteorologique de Belgique, Brussels, Belgium.

ENEA. 1987. Post Chernobyl-4: exposure intensity measurement in Saluggia (Vercelli). ENEA, Rome, Italy. 
Eberle, S.H.; Fuchs, F.; Haberer, K.; Summers, S.; Sontheimer, H. 1987. Radioactive contamination of untreated water and water treatment to obtain drinking water. Study commissioned by the Ministry of Food Agriculture, Environment and Forestry of the Land Baden-Wuerttemberg. Uimer, Stuttgart, Germany, F.R.

Eckered, T. 1986. "Safety of boiling water systems: the repercussions of TMI and Chernobyl on Swedish reactors." In SVA information meeting on safety of nuclear power plants in the light of TMI and Chernobyl. Schweizerische Vereinigung fuer Atomenergie, Bern, Switzerland.

Eckered, T. 1986. "Chernobyl book written in three weeks." Nucl. Eur. $6(11): 26$.

Eden, R.; Evans, N. 1986. Electricity supply in the UK. Gower Publishing Company, Aldershot, U.K.

Eder, E. 1986. "Measuring programmes for detemining contamination levels after the Chernobyl reactor accident." Gesund.-Ing. 107(5):274-289.

Eder, E.; Starke, H. 1987. "Further development of the remote monitoring system for nuclear reactors in Bavaria." Kerntechnik 50(3):157-162.

Ederer, F.: Schulz, W.: Steinkamm, A. (eds.). 1987. Report on the state of the energy discussion 1984/85. Lectures given at a seminar with excursions on the subject 'Problems of energy supply at the levels of the national economy and law during the autumn and winter trimester of 1984/85. INIS-mf-11815, Universitaet der Bundeswehr Muenchen, Neubiberg, Germany, F.R.

Edmondson, B. 1987. "Chernobyl accident and its implications for operators of civil nuclear power plant in the UK." In Conference on nuclear risks reassessing the principles and practical after Chernobyl. IBC Technical Services Ltd., London, U.K.

Edmondson, B. 1987. "United Kingdom nuclear reactor design and operation." Br. J. Radiol. 60(720):1174-1177.

Edwards, R. 1986. "Chernobyl: the political fall-out." Ecologist $16(4-5): 140-143$.

Eendebak, B.T. 1986. "Chernobyl reactor accident." NVS-Nieuws 11(3):4-8.

Ehling, U.H. 1987. "Quantification of the radiation-induced genetic risk." Strahlenther. Onkol. 163(5):283-291.

Ehrhardt, J.: Jacob, P. 1986. "Models for accident consequence assessment with preliminary verification following the Chernobyl reactor accident." In SVA information meeting on safety of nuclear power plants in the light of TMI and Chernobyl. Schweizerische Vereinigung fuer Atomenergie, Bern, Switzerland. 
Ehrhardt, J.; Panitz, H.J. 1986. "Main points of further development of accident sequence model UFOMOD and first analyses of the Chernobyl reactor accident." In Colloguium of the Projekt Nukleare Sicherheit (PNS) of the Kernforschungszentrum Karlsruhe G.m.b.H. Kernforschungszentrum Karisruhe G.m.b.H., Germany, F.R.

Eisenlohr, H.H. 1987. "SSDL Network, radiation protection and the principle of measurement traceability." Radiat. Prot. Dosim. 18(2):113-114.

Eitz, A.W.: Recker, M.; Uffmann, D. 1986. "Consequences of opting out of nuclear energy. Arguments of the opting out discussion." Energiewirtsch. Tagesfragen $36(11): 827-835$.

Elderkin, C.E. 1988. Pacific Northwest Laboratory annual report for 1987 to the DOE Office of Energy Research: Part 3, Atmospheric sciences.

PNL-6500-Part 3, Pacific Northwest Lab., Richland, WA, U.S.A.

Elderkin, C.E. 1987. Pacific Northwest Laboratory: Annual report for 1986 to the DOE Office of Energy Research: Part 3, Atmospheric sciences. PNL-6500-Part 3, Pacific Northwest Lab., Richland, WA, U.S.A.

Endlicher, W. 1987. Exposure to natural radiation from the atmosphere and outer space. Hosemann, G.; Wirth, E. (eds.), INIS-mf-11696, Freíburg Univ., Freiburg, Germany, F.R.

Enge I, R.: Gaber, H.; Loeser, G.; Roth-Stielow, K. 1986. Chernobyl: The super MCA. Consequences for nature, man and energy policy. Dreisam-Verl., Freiburg im Breisgau, Germany, F.R.

Enthoven, M.E.E. 1987. "Organization of post-Chernobyl management in The Netherlands. Chapter 10." In Chernobyl - environment and health aspects. Van Loon, A.J. (ed.), KIVI-Kerntechnjek, Arnhen, Netherlands.

Erbstein, F. 1987. "Of topical interest since the Chernobyl accident: Cesium transport in soil as a function of water movement and soil type." Junge Wissensch. 2(7):26-31.

Eriksson, 0.; Mogren, A. 1986. Out of blind alloys. Study of electric power policy having efficient use as main strategy and on outline of an industry - compatible application. After Chernobyl. Statens Energiverk, Stockholm, Sweden.

Erlandsson, B.; Mattsson, S. 1988. "Uptake of dry-deposited radionuclides in Fucus - a field study after the Chernobyl accident." J. Environ. Radioact. $6(3): 271-281$.

Ernst, K. 1987. "Special features of hands injured by radiation." In 27. annual conference of Vereinigung Deutscher Strahlenschutzaerzte e.V. Schuetz, J.; Boerner, W.; Messerschmidt, 0. (eds), CoNF-8605338, Thieme, Stuttgart, Germany, F.R. 
Ernst, W.H.0.; Van Rooij, L.F. 1987. "Cs-134/Cs-137 fall-out from Chernobyl in Dutch forest." In 6 . international conference on heavy metals in the environment. Lindberg, S.E.; Hutchinson, T.C. (eds.), ORNL/M-463, Free Univ., Amsterdam, Netherlands.

Erskine, R.; Webber, P. 1988. Accidents, risks and consequences. Mackay, L.; Thompson, M, Pluto Press, London, U.K.

Esteves, D. 1986. Chernobylsk accident (Causes and Consequences). Part 1. Comissao Nacional de Énergia Nuclear de Brasil, Rio de Janeiro, Brazil.

Esteves, D. 1986. Chernobylsk accident (Causes and Consequences). Part 2. Comissao Nacional de Energia Nuclear de Brasil, Rio de Janeiro, Brazil.

Ettemeyer, R. 1986. Chernobyl and its consequences. IAEA, Vienna, Austria.

Evans, N. 1986. Assessing the risks of nuclear energy. Harrison, A.; Gretton, J. (eds.), Policy Journals, Newbury, U.K.

Evans, N.; Bullen, W. 1986. Nuclear power in the Western world post-Chernobyl. Cambridge Energy Reasearch Ltd., Cambridge, U.K.

Ewe, T. 1986. "Chernobyl - the nuclear disaster. Disaster control in West Germany: Helpless." Bild Wiss. 23(7):58-75.

Ewen, K. 1987. "Professional radiation exposure in X-ray diagnostics." In 27. annual conference of Vereinigung Deutscher Strahlenschutzaerzte e.V. Schuetz, J.: Boerner, W.; Messerschmidt, 0. (eds.), CONF-8605338, Thieme, Stuttgart, Germany, F.R.

Fach, W.; Simonis, G. 1987. Strength of the state in the nuclear conflict. France and the Federal Republic of Germany as compared to one another. Campus Verl., Frankfurt an Main, Germany, F.R.

Falconer, I.R. 1986. "TI in ruminant thyroids after nuclear releases." Nature $322(6081): 692$.

Faude, D. 1987. "Energy supply without nuclear power." ATW, Atomwirtsch., Atomtech. 32(1):41-45.

Faure, J.; Duclos, P; Fache, P.; Rzepka, J.P. 1987. "Accident of Chernobylsk: interventions and consequences on the nuclear power plant and on the environment." In SFEN meeting on Chernobyl accident: safety and environmental aspects. CEA Centre d'Etudes Nucleaires de Fontenay-aux-Roses, France.

Fazliu, Sh.; Morina, A.; Rechica, F. 1987. "Intensities of exposure doses to garma radiation: - At the whole territory of SAP Kosovo, measured after the Chernobyl nuclear accident." In 14. Yugoslay symposium on radiation protection. Yugoslav Radiological Protection Association, Novi Sad, Yugoslavia. 
Fazliu, Sh.; Morina, H.; Rechica, F. 1987. "Daily maximal intensities of the exposure doses to gamma radiation measured at the park of the occupational medicine dispensery 0bilicj in the period 01.05.86 - 31.12.1986." In 14. Yugoslav symposium on radiation protection. Yugoslav Radiological Protection Association, Novi Sad, Yugoslavia.

Feely, H.W.; Helfer, I.K.; Juzdan, Z.R.; Klusek, C.S.; Larsen, R.J. ; Leifer, R. 1988. "Fallout in the New York metropolitan area following the Chernobyl accident." J. Environ. Radioact. 7(2):177-191.

Feldmann, A. 1986. "Radiation exposure as a result of the Chernobyt accident." Phys. Unserer Zeit 17(5):129-131.

Feldmann, J.; Janme, H.P. 1987. "European Community's coal market caught between collapsing oil prices and the falling dollar - facts, trends and prospects." Glueckauf 123(6):291-299.

Feldmann, U. 1987. "Peaceful uses of nuclear energy and national borders in Central Europe. Report about the first regional meeting of the German National Group of AIDN/INLA held in Regensburg, September 22-23, 1986." ATW, Atomwirtsch., Atomtech. 32(3):144-146.

Feldt, W. 1987. "Radioactive contamination of the North Sea and the Baltic Sea - a status report (September 1986)." In AIDN/INLA regional conference on peaceful uses of nuclear energy and state frontiers in Central Europe. Pelzer, N. (ed.), Nomos Verlagsges, Baden-Baden, Germany, F.R.

Fells, I. 1986. "Energy: to have and have not." Atom 362:18-20.

Feoktistov, L. 1987. "Are accidents of nuclear power plants possible?" Vesmir $66(2): 85$.

Fett, F.N.; Krumm, W.; Pfeifer, H. 1987. "Electricity generation from regenerative energy sources - a substitute for nuclear energy." Brennst. -Waerme-Kraft 39(3):71-79.

Feuerstein, H. 1987. "Conditions during the release of radionuclides during the Chernobyl reactor accident." Kerntechnik 51(1):55-59.

Fields, D.E.; Ozluoglu, N.; Yalcintas, M.G. 1987. "Impact of the Chernobyl accident on Turkey." In Joint meeting of the American Nuclear Society and the Atomic Industrial Forum. Oak Ridge National Lab., Oak Ridge, TN, U.S.A.

Fieuw, G.; Govaerts, P. 1986. "Radiation impact of the reactor accident at Chernobyl." Rev. Quest. Sci. 157(4):475-498.

Finckh, E.; Gremm, 0. 1987. What happened in Chernobyl? Hosemann, G.; Wirth, E. (eds.), INIS-mf-11696, Erlangen-Nuernberg Univ., ErTangen, Germany, F.R.

Fink, U. 1988. "Critical comments on and alternatives to current radiation protection policy." WSI Mitt. 2:124-131. 
Finnish Centre for Radiation and Nuclear Safety. 1986. 2. interim report on radiation situation in Finland from 5 to 16 May 1986. Finnish Centre for Radiation and Nuclear Safety, Hels inki, Finland.

Finucane, M. 1988. "Information and tools required for a fire PSA." In International approach to nuclear safety seminar. Ballard, G.M. (ed.), CONF-8806174, Elsevier Applied Science, London, U. K.

Finzi, S.; 01ast, M.; Sinnaeve, J. 1987. "Opening address." Radiat. Prot. Dosim. $21(1-3): 9-11$.

Fjorentini, P.; Savelli, D. 1987. "Nuclear power in the world." Energ. Nucl. $4(1): 117-126$.

Fischer, C.; Fischer, R. 1986. No need to worry about your food. A guide to compose one's proper and wholesome diet in the current situation after the Chernobyl accident. (2nd edition). Heyne, Muenchen, Germany, F.R.

Fischer, H.; Moser, D.; Urbach, M. 1986. Chernobyl reactor accident and its effects on the Bremen area. Radioactivity measurements from May through September 1986 and dose assessment. INIS-mf-11839, Bremen Univ., Germany, F.R.

Fischer, J. (ed.). 1986. Opting out of nuclear energy is feasible. Rowohlt Taschenbuch Veri., Reinbek, Germany, F.R.

Fischetti, M.A. 1986. "Radioactive cloud over Europe." Tech. Rundsch. $78(48): 52-57$.

Fischetti, M.A. 1986. "The puzzle of Chernobyl." IEEE Spectrum 23(7):34-41.

Fischetti, M.A.; Zorpette, G. 1987. "Power and energy." IEEE Spectrum $24(1): 53-55$.

Flaemig, G. 1986. "Chernobyl and the consequences." At. Strom 32(3):89-91.

Flavin, C. 1987. "Awakening from the nuclear dream." OPEC Bul1. 18(3):14-19.

Flavin, C. 1987. "Prometheus bound: how safe is nuclear power?" Sci. Today $21(4): 42-45$.

Flavin, C. 1987. "Nuclear safety after Chernoby1." Environ. Sci. Technol. $21(7): 624-625$.

Flavin, C. 1987. "Nuclear power's burdened future." Bull. At. Sci. $43(6): 26-31$.

Flavin, C. 1987. "After Chernoby1. Reassessing the costs of nuclear power." Eur. Environ. Rev. 1(3):38-43.

Fletcher, C.D.; Chambers, R.; Bolander, M.A.; Dallman, R.J. 1988. "Simulation of the Chernobyl accident." Nucl. Eng. Des. 105(2):157-172. 
Flood, M. 1986. Energy without end. The case for renewable energy. Friends of the Earth Trust, London, U.K.

Florou, H. (ed.). 1987. Consequences of the Chernobyl reactor accident in the Greek marine environment. Technical report. National Centre for Marine Research, Athens, Greece.

Flowers, R.H. 1986. "Dragon's exhalations give clue to Chernobyl." Nature $323(6085): 208$.

Floyd, P.J. 1987. "Impact of Chernobyl." In Conference on nuclear risks reassessing the principles and practical after Chernobyl. IBC Technical Services Ltd., London, U.K.

Ford, B.C.; Jester, W.A.; Griffith, S.M.; Morse, R.A.; Zall, R.R.; Lisk, D.J.; Burgett, D.M. 1988. "Cesium-134 and cesium-137 in honey bees and cheese samples collected in the U.S. after the Chernobyl accident." Chemosphere $17(6): 1153-1157$.

Fors, J.: Magnusson, L. 1986. Gasification of indigenous fuels for electric power production at combined power and heating plants. After Chernobyl. Statens Energiverk, Stockholm, Sweden.

Forschungsstaette der Evangelischen Studiengemeinschaft (FEST). 1986. Chernoby1 - consequences and conclusions. 30 theses on the relationship between technology and politics. Statement published by the FEST. Forschungsstaette der Evangelischen, Studiengemeinschaft, Germany, F.R.

Forsyth, M.; Foulkes, G.; Wallace, J.; Robertson, J.H.; Monro, H.; Livsey, R.; Walker, B. 1988. "Food protection." Hansard, House Commons Off. Rep. $125(76): 1061-1069$.

Fowler, S.W.; Ballestra, S.; Holm, E.; Buat-Menard, P.; Yokoyama, Yugi; Van Nguyen, H. 1987. "Rapid removal of Chernobyl fallout from Mediterranean surface waters by biological activity." Nature 329(6134):56-58.

Franchois, H.; Vuyst, P. de. 1986. "Safety assessment at the DOEL nuclear power plant site." In Seminar on the Chernobyl accident and its impact. IAEA, Vienna, Austria.

Francis, L. 1986. "Inquiries from the public about the Chernobyl accident." Radiol. Prot. Bul1. 76:11-16.

Franke, B. 1986. Lessons from Chernobyl - A european perspective. Nuclear Information and Resource Service, Washington, DC, U.S.A.

Franke, B.; Giegrich, J.; Schmidt, M. 1987. Variation range of the radiation dose and health risk by Chernobyl fallout in Hamburg - May to August 1986. Schmidt, M. (ed.), IFEU-49, Verl. Das Wunderhorn, Heidelberg, Germany, F.R. 
Franta, J. 1988. "Comment on Cohen's article on the Chernobyl disaster." Am. J. Phys. $56(8): 679-679$.

Franzen, F.L. 1986. "Evaluation of the Chernobyl reactor accident (as of May 30, 1986)." In Information meeting on the Chernobyl reactor accident and the resulting radioactive exposure in the Federal Republic of Germany.

Gesellschaft fuer Energiewissenschaft und Energiepolitike.V. (GEE), Bonn, Germany, F.R.

Fremtin, J.H. 1987. "How many Chernobyl fatalities?" Nature 327(6121):376.

Fremlin, J.H. 1986. "Hazards of civil nuclear power in the light of the Chernobyl disaster." Sci. Parliam. 143(185):221-222.

French Institute of Protection and Nuclear Safety. 1986. The Chernobyl Accident Gesellschaft fuer Energiewissenschaft und Energiepolitik e.V. (GEE), Bonn, Germany, F.R.

Frewer, H.; Braun, W.; Freiberger, S.: Martin, J. 1986. Can we dispense with nuclear power? Kraftwerk Union A.G., Ruhr, Germany, F.R.

Friederichs, H.G. 1987. "Fission product source term in severe accident situations." In Seminar concerning safety studies on severe accident in light water reactors. EUR-11019, Gesellschaft fuer Reaktorsicherheit (GRS), Koeln, Germany, F.R.

Friederichs, H.G.; Schroed1, E. 1986. "Recent results of fission product release from the core and from the reactor containment after accidents." In 10. GRS expert's meeting on results of new safety analyses. Gesellschaft fuer Reaktorsicherheit m.b.H. (GRS), Koein, Germany, F.R.

Friedmann, H.; Hernegger, F.; Wagner, M.; Weselka, D.; Wild, E. 1987. Determination of radioactive isotopes from the Chernobyl accident in Vienna. Wild, E.; Dirnider, G. (eds.), Oesterreichische Akademie der Wissenschaften, Vienna, Austria.

Friedmann, L.; Amann, W.; Lux, D. 1986. "Radioactive contamination of waters in Bavaria following the Chernobyl accident." GWF, Gas-Wasserfach $127(12): 604-613$.

Frigren, S. 1987. "Energy savings in connection with the phasing out of nuclear power stations." In 1 . international symposium on energy savings focusing on electricity savings. CONF-8709321, Association of Danish Electric Utilities, Copenhagen, Denmark.

Frissel, M.J. 1987. "Radiation levels and radioactivity measurements in The Netherlands caused by the Chernobyl accident. Chapter 7." In How can the engineer minimize the risks of nuclear power plants?. Van Loon, A.J. (ed.), KIVI-Kerntechniek, Arnhem, Netherlands.

Fritz-Niggli, H. 1986. "Effect of the Chernobyl radioactivity on humans." Bull. Assoc. Suisse Electr. $77(18): 1182-1184$. 
Fruehling, J.; Henry, J. 1987. "Whole-body counter measurement of the contamination of persons exposed following the Chernobyl accident." Bull. Mem. Acad. R. Med. Belg. 142(4-5):286-296.

Frullani, S. 1987. "Istituto Superiore di Sanita' Physics Laboratory: Activities related to Chernobyl consequences in Italy." In Conference AIRP sull'incidente di Chernobyl. Ass. It. Protezione Contro le Radiazioni, Bologna, Italy.

Fry, F.A. 1987. "Chernobyl reactor accident: the impact on the United Kingdom." Br. J. Radiol. 60(720):1147-1158.

Fry, F.A.; Britcher, A. 1987. "Doses from Chernobyl radiocaesium." Lancet $2: 160-161$.

Fry, F.A.; Clarke, R.H.; O'Riordan, M.C. 1986. "Early estimates of UK radiation doses from the Chernobyl reactor." Nature 321(6067):193-195.

Fuchs, H.: Zuend, H. 1986. "Lessons from the IAEA Seminar." Electro-Rev. $78(22): 39-40$.

Fuge, R. 1987. "Iodine in the environment: its distribution and relationship to human health." In 21. annual conference on trace substances in environmental health. Hemphil1, D.D. (ed.), CoNF-8705217, University of Missouri, Columbia, Mo, U.S.A.

Fulker, M.J. 1987. "Aspects of environmental monitoring by British Nuclear Fuels plc following the Chernoby1 reactor accident." J. Environ. Radioact. $5(3): 235-244$.

G. Bengtsson. 1986. Chernobyl - Its Impact on Sweden Statens Stralskyddinstitut, National Institute of Radiation Protection, Stockholm, Sweden.

GAEC. 1986. The Consequences of the Chernobyl Nuclear Accident in Greece Greek Atomic Energy Commission, Democritos 86/4, Athens, Greece.

GAEC. 1986. The Consequences of the Chernobyl Nuclear Accident in Greece Report No. 2 Greek Atomic Energy Commission, Democritos 86/9, Athens.

Gaeggeler, H. (ed.). 1988. Progress report 1986/87 of the chemistry department. PSI-8, Paul Scherrer Inst. (PSI), Wuerentingen, Switzerland.

Gaffney, R.D.; Chatterton, B.E. 1987. "Estimates of contamination after the Chernobyl nuclear accident." Aust. N.Z. J. Med. 17(4):484.

Gale, R.P. 1987. "Imnediate medical consequences of nuclear accidents: lessons from Chernobyl." J. Am. Med. Assoc. 258(5):625-628.

Galoczi, I.; Haszpra, L.; Horvath, L. 1987. "Atmospheric impact of Chernobyl reactor accident in Hungary." Termesz. Vilaga 118(2):57-61. 
Gambaroff, M.; Mies, M.; Stopczyk, A.; Von Werlhof, C. 1986. Chernobyl accident has changed our life. What made women radically change their conception of life? Rowohlt Taschenbuch Verl., Reinbek, Germany, F.R.

Gangadharan, A.; Hassan, Y.A. 1987. "Containment pressure assessment using the COBRA-NC computer code." Trans. Am. NuCl. SoC. 55:757-758.

Gans, I.; Ruehle, H. 1986. "Radioactive substances in venison (roe) due to the Chernobyl accident." Bundesgesundheitsblatt 29(12):397-398.

Gans, I.; Ruehle, H.; Buenger, T.; Beckmann, D. 1986. "Monitoring of radioactivity in sewage and sewage sludge - the Chernobyl reactor accident." Bundesgesundheitsblatt $29(10): 305-314$.

Garde1, A. 1986. "Reflections on the future of energy in Switzerland and the world." Bull. Assoc. Suisse Electr. 77(20):1282-1319.

Garrido, G.; Vacchiano, C. 1987. "Structure of public opinion and the nuclear debate in Spain." In 11. annual symposium of the Uranium Institute.

CONF-860915, Uranium Institute, London, U.K.

Gassmann, F. 1986. "Pollutant dispersion in the atmosphere: latest investigations concerning transport and diffusion processes." In SVA information meeting on safety of nuclear power plants in the light of TMI and Chernobyl. Schweizerische Vereinigung fuer Atomenergie, Bern, Switzerland.

Gasteiger, R.; Matter, J. 1986. "Wackersdorf and Chernobyl - two plants defying comparison." Energie 38(10):22-26.

Gasteiger, R.; Mattern, J. 1986. "Safety of Wackersdorf reprocessing plant (WAW) in the light of the Chernobyl reactor accident." At. Stromz $32(5): 171-173$.

Gattavecchia, E.; Ghini, S.; Tonelli, D. 1988. "Cs-137 transfer for forage to milk and its removal by clay treatment." J. Radioanal. Nucl. Chem. $121(1): 9-15$.

Gauvenet, A. 1986. "Chernobyl accident: its causes and its consequences." Rev. Energ. 387:867-873.

Gavrilov, S.D. 1988. "Mobil robotics for nuclear plants." At. Tekh. Rubezhom $3: 11-17$.

Geary, Neville (ed.). 1987. Nuclear technology international 1987. Sterling Publications Ltd., London, U.K.

Geiger, H.J. 1986. "Accident at Chernobyl and the medical response." Biochemistry 256(5):609-612. 
Geissler, A.; Riegert, B. 1988. Energy policy for a future worth living. Coal vs. Super-MCA. Verl. Neue Gesellschaft, Bonn, Germany, F.R.

General Accounting 0ffice. 1986. Nuclear Energy: Compendium of relevant GAO products on regulation, health, and safety. General Accounting Office, Washington, D.C., U.S.A.

General Accounting Office. 1986. Nuclear safety: Comparison of DOE's Hanford $\mathrm{N}$-reactor with the Chernobyl reactor. General Accounting Office, Washington, D.C., U.S.A.

Gentile, G.; Trenti, F.; Calamosca, M. 1987. "Retention of radionuclides in cattle exposed to the fallout of Chernobyl: The course and the usefulness of a model for its prediction." Dtsch. Tieraerztl. Wochenschr. 94(5):252-258.

Gepp, J.; Teich, T. (eds.). 1987. Communications of the naturat-sciences association for Styria. Vol. 117. Graz Univ., Graz, Austria.

Gerber, B.G.; Metivier, H.J.; Smith, H. 1987. Age-related factors in radionuclide metabolism and dosimetry. Kluwer Boston Inc., Hingham, MA, U.S.A.

Gergely, S.M. 1986. Radiation danger. Verlag Carl Ueberreuter, Vienna, Austria.

Gericht des Instituts fr Strahlenschutz der Gesellischaft fr Strahlen-und Unweltforschung. 1986. Umweltradioaktivitt und Strahlenexposition in Sudbayern Durch Den Tschernobyl-Unfall Verlag Carl Veberreuter, Vienna, Austria.

Gerosa, K. 1986. Reactor accidents and how to protect oneself from them. Emergency measures. Luebbe, Bergisch Gladbach, Germany, F.R.

Gerzabek, M. 1986. "How do radionuclides behave in soils?" Agro Zucker 4:4.

Gesellschaft fuer Reaktorsicherheit m.b.H. (GRS). 1986. Recent findings about the Chernobyl reactor accident. Part. 1 and 2. Part. 1: Summary and evaluation of information provided on the plant and the course of the accident. Part. 2: Radiological repercussions in the Federal Republic of Germany. Gesellschaft fuer Reaktorsicherheit m.b.H. (GRS), Koeln, Germany, F.R.

Gesellschaft fuer Strahlen-und Umweltforschung m.b.H. Muenchen. 1986. Environmental radioactivity and radiation exposure in southern Bavaria after the Chernobyl accident. Gesellschaft fuer Strahlen-und Unweltforschung m.b.H. Muenchen, Neuherberg, Gemany, F.R.

Geyh, M.; Hennig, G.J.; Kruck, H.; Scholz, R.; Barthel, F.; Bulla, K.; Siewers, U. 1987. Radiation exposure in Lower Saxony as a result of the Chernobyl reactor accjdent. Bundesforschungsanstalt fuer Landeskunde und Raumordnung, Bonn, Germany, F.R. 
Giacomelli, R.; Spezzano, P.; Nocente, M.; Bortoluzzi, S.; Dattrino, A.; Massironi, L. 1987. Post Chernobyl-6. Measurement of radiation in vegetables at Crescentino and $S$. Germano Vercellese. ENEA, Rone, Italy.

Giacomelli, R.; Spezzano, P.; Nocente, M.; Dattrino, A.: Massironi, L.; Ornaghi, A. 1987. Post Chernobyl-1. Measurements of radionuclides at Saluggia (Vercelli). ENEA, Rome, Italy.

Giacomelli, R.; Spezzano, P.; Nocente, M.; Dattrino, A.: Massironi, L.; Ornaghi, A. 1987. Post Chernobyl-2. Measurement of radionuclides in the fallout at Saluggia (Vercelli). ENEA, Rome, Italy.

Giacomelli, R.; Spezzano, P.; Nocente, M.; Dattrino, A.; Massironi, L.; Ornaghi, A. 1987. Post Chernobyl-4: radionuclides measurement in Saluggia (Vercelii) ground. ENEA, Rome, Italy.

Giani, L.; Gebhardt, H.; Gusy, W.; Helmers, H. 1987. "Behavior of some radioactive nuclides (released during the Chernobyl disaster) in typical North German soils." Z. Pflanzenernaehr. Bodenkd. 150(2):103-107.

Giese, W. 1986. "Isotopes of the radioactive fallout and their occurrence in milk, seen from the point of view of veterinary medicine." Prakt. Tierartz $7: 561-569$.

Gillon, L. 1986. "Accident at the Chernobyl nuclear power plant." Rev. Quest. Sci. 157(4):421-444.

Gillon, L. 1986. "Lesson from Chernoby1 and its consequences for the comunity." Rev. Quest. Sci. 157(4):557-580.

Giliwald, K. 1986. Chernobyl: The aftermath. Reflections on environmental science and policy after the nuclear accident in Chernobyl.

Wissenschaftszentrum Berlin fuer Sozialforschung gGmbH (WZB), Germany, F.R.

Gittus, J.H. 1988. "Nuclear power - a perspective." In International approach to nuclear safety seminar. Ballard, G.M. (ed.), CoNF-8806174, Elsevier Applied Science, London, U.K.

Gittus, J.H. 1987. "Chernobyl releases." Phys. Bull. 38(4):126.

Gittus, J.H. 1986. "Chernobyl accident." Atom 357:16-17.

Gittus, J.H. 1987. "Chernobyl accident and its consequences." Atom 368:2-9.

Gittus, J.H. 1986. "Evaluation of Soviet information on Chernobyl." Nucl. Eur. 6(11):18-19.

Gittus, J.H.; Bonell, P.G.; Hicks, D. 1987. Chernobyl accident and its consequences. H.M. Stationary Office, London, U.K.

Gittus, J.H.; Hicks, D.; Bone 11, P.G. 1988. Accident at Chernobyl. N0R-4200, United Kingdom Atomic Energy Authority, London, U.K. 
Gittus, J.H.; Hicks, D.; Bone11, P.G. 1988. Environmental consequences. NOR-4200, United Kingdom Atomic Energy Authority, London, U.K.

Gittus, J.H.; Hicks, D.; Bone 11, P.G. 1988. Executive summary. N0R-4200, United Kingdom Atomic Energy Authority, London, U.K.

Gittus, J.H.; Hicks, D.; Bonell, P.G. 1988. NNC safety reservations. NOR-4200, United Kingdom Atomic Energy Authority, London, U.K.

Gittus, J.H.; Hicks, D.; Bonell, P.G. 1988. Source terms. N0R-4200, United Kingdom Atomic Energy Authority, London, U.K.

Gittus, J.H.; Hicks, D.: Bone11, P.G.; et al. 1988. Description of the RBMK reactors. NOR-4200, United Kingdom Atomic Energy Authority; H.M. Stationery office, London, U.K.

Gittus, J.H.; Hicks, D.; Bone11, P.G.; et al. 1988. Post-Chernobyl design changes to RBMK reactors. NOR-4200, United Kingdom Atomic Energy Authority; H.M. Stationery Office, London, U.K.

Gittus, J.H.; Hicks, D.; Bonel1, P.G.; et al. 1988. USSR power reactor programme. NOR-4200, United Kingdom Atomic Energy Authority; H.M. Stationery office, London, U.K.

Gjoerup, H.L. 1987. "Countermeasures and socio-economic considerations." Radiat. Prot. Dosim. 21(1-3):145-150.

Gockel, H.P. (ed.). 1987. Radiology yearbook 1987. Regensberg und Biermann, Muenster, Germany, F.R.

Godlewski, N.Z.: Payne, J.; Tompkins, B. 1987. "Changing world of nuclear power." Nucl. News 30(1):83-90.

Goerlich, W.; Portmann, W.; Wernli, C.; Linder, P.; Burkart, W. 1988. Chernobyl-fallout, EIR-database and some correlations for 1986-1987. PSI-1, Paul Scherrer Inst. (PSI), Wuerenlingen, Switzerland.

Gogolak, C.V.; Winkelmann, I,; Weimer, S.; Wolff, S.; Klopfer, P. 1986. Observations of Chernobyl fallout in Germany by in situ gamma-ray spectrometry. Volchok, H.L.; Chieco, N. (eds.), USDOE Environmental Measurements Lab., New York, NY, U.S.A.

Goldman, M.; Catlin, R.J.; Anspaugh, L. 1987. Health and environmental consequences of the Chernobyl nuclear power plant accident. Committee on the Assessment of Health Consequences in Exposed Populations, Washington, D.C., U.S.A.

Golubev, E.K.; Glazov, E.E.; Plokhij, T.G.; Bronnikov, V.K.; Vakulenko, B.F.; Mikhajlov, V.S. 1982. "Evaporator operation at the Chernobylskaya MPP k-500-65/3000 turbine unit." Teploenergetika 11:32-34. 
Gonzalez, A.J.; Frischengruber, K.; Recalde, J.A.; Solanilla, R.B.; Vanzulli, R.C.: Garribba, S. 1987. "ARGOS PHWR 380. Argentine offer of a safer pressurized heavy-water reactor of $380 \mathrm{MW}$. '... many-eyed guardian..' concerned about nuclear power plant safety." In Seminar on small and medium-sized nuclear reactors: safety and licensing issues. EPFL, Lausanne, Switzerland.

Gornig, G. 1986. "Compensation for damage in the case of transfrontier reactor accidents." Juristenzeitung $41(21): 979-986$.

Gorst, I. 1987. "Gas and nuclear fuel replacing oil: East European energy planning." Pet. Econ. 54(5):174, 191.

Gosudarstvennyj Komitet po Ispol'zovaniyu Atomnoj Ehnergi. 1986. Accident at the Chernobyl AES and its consequences. Data prepared for the International Atomic Energy Agency Expert Conference (25-29 August 1986, Vienna). USDOE, U.S.A.

Gosudarstvennyj Komitet po Ispol'zovaniyu Atomnoj Ehnergi i SSSR. 1986. Post-accident review meeting slides. Part II. Gosudarstvennyj Konitet po Ispol'zovaniyu Atomnoj Ehnergi i SSSR, Moscow, U.S.S.R.

Gosudarstvennyj Konitet po Ispol'zovaniyu Atomnoj Ehnergi i SSSR. 1986. Accident at the Chernobyl nuclear power plant and its consequences. Part I. General material. Draft. Gosudarstvennyj Komitet po Ispol'zovaniyu Atomnoj Ehnergii SSSR, Moscow, U.S.S.R.

Gosudarstvennyj Komitet po Ispol'zovaniyu Atomnoj Ehnergii SSSR. 1986. Accident at the Chernobyl' nuclear power plant and its consequences. Part II. Annexes 1,3,4,5,6. Draft. Gosudarstvennyj Komitet po Ispol'zovaniyu Atomnoj Ehnergit SSSR, Moscow, U.S.S.R.

Gosudarstvennyj Komitet po Ispol'zovaniyu Atomnoj Ehnergi i SSSR. 1986. Accident at the Chernobyl' nuclear power plant and its consequences. Part II. Annexes 2, 7. Draft. Gosudarstvennyj Konitet po Ispol'zovaniyu Atomno $j$ Ehnergii SSSR, Moscow, U.S.S.R.

Gosudarstvennyj Komitet po Ispol'zovaniyu Atomnoj Ehnergi i SSSR. 1986. Post-accident review meeting slides. Gosudarstvennyj Komitet po Ispol'zovaniyu Atomnoj Ehnergii SSSR, Moscow, U.S.S.R.

Gouffon, A. 1987. "Developments concerning reactivity accidents in PWRs." In Meeting of the technical committee on safety matters lint to accidents caused by a reactivity transient. CEA Centre d'Etudes Nucleaires de Fontenay-aux-Roses, France.

Govaerts, P.; Fieuw, G.: Deworm, J.P.; Zeevaert, Th. 1986. "Assessment of doses received by the Belgian population due to the Chernobyl releases." In Seminar on the Chernobyl accident and its impact. IAEA, Vienna, Austria. 
Gragnani, R.; Michetti, I.; Tarroni, G.; Testa, L. 1987. Principal radionuclide distribution of airborne particulate matter at Casaccia (Rome) following the Chernobyl accident. ENEA, Rome, Italy.

Graham. 1987. "A non-governmental Parliamentary view of the reclamation, treatment and utilization of coal mining wastes - set in the context of Britain's environmental renaissance." In 2. international symposium on the reclamation, treatment and utilization of coal mining wastes. Rainbow, A.K.M. (ed.), Elsevier Science Publishers, Amsterdam, Netherlands.

Gramberg, M.; Weber, R.; Malmstroem, R.; Kobbe, B. 1986. "NucTear energy policy of our neigbours." Bild Wiss. $23(8): 12-21$.

Grass1, H. 1987. "Wide-spread and local distribution of emission." In AGF congress on Chernobyl and the future of energy supply in the Federal Republic of Germany. GKSS-Forschungszentrum Gees thacht G.m.b.H., Geesthacht-Tesperhude, Germany, F.R.

Grauby, A.; Maubert, H.; LaBrecque, J.J.; Schelenz, R.: Perkins, R.H. 1987. "Follow-up of grass radioactivity after the Chernobyl accident in the watershed of the river Var." In Consultants' meeting on the determination of radionuclides in grass ecosystem samples. IAEA, Seibersdorf, Austria.

Graves, W.E. 1986. 'Inherent safety'' as applied to new production reactors. DPST-86-519, Savannah River Lab., Aiken, SC, U.S.A.

Grawe, J. 1988. New technologies for power generation. 2. rev. ed. Verl. Bonn Aktue 11, Stuttgart, Germany, F.R.

Green, P. 1987. "Chernobyl controversy." SCRAM: Anti-Nucl. Safe Energy J. $60: 22-23$.

Green, P. 1988. "Unreal radiation response." SCRAM: Anti-Nucl. Safe Energy 3. $64: 11$.

Green, P.; Sampson, K. 1988. "Catalogue of blunders." SCRAM: Anti-Nucl. Safe Energy 3. $67: 8-9$.

Greger, T.; Cristensen, T. 1986. Information at radiation accidents. A study on the needs for information among health visitors and famers. Statens Inst. for Straalehygiene, Oslo, Norway.

Gribat, A.G. 1986. "Prospects of hard coal in world trade." Erdoel Erdg. Kohl. $102(9): 412-416$.

Gritsenko, A.S.; Zavgorodnij, I.M. 1984. "Work mechanization scheme used during the main building construction of the second phase of the Chernobylsk NPP." Energ. Stroit. 11:10-12.

Grove, H.H. 1987. "One year after Chernoby1. Part. 1. The situation as it is seen by the veterinarian authority." Arch. LebensmitteThyg. 38(3):80-83. 
Grove-White, R. 1987. "Planning for the future in the light of the Sizewell $B$ decision." In Conference on the future of nuclear power after Sizewell $B$. CONF-8709242, IBC Technical Services Ltd., London, U.K.

Gruemm, H. 1988. "Nuclear power after Chernobyl." VGB Kraftwerkstech. $68(1): 4-7$.

Gruh1, H. 1988. Nuclear suicide. (Revised Edition). Ullstein, Frankfurt am Main, Germany, F.R.

Grunwald, J. 1986. "Chernobyl and the law of the European Communities." Europarecht $21(4): 316-339$.

Guarino, A. 1987. "Environmental aspects of the pacific use of atomic energy: The nuclear paradox." In Conference AIRP sull'incidente di Chernobyl. Ass. It. Protezione Contro le Radiazioni, Bologna, Italy.

Gudiksen, P.H. and Lange, R. 1986. Atmospheric Dispersion Modeling of Radioactivity Releases from the Chernobyl Event Lawrence Livermore National Laboratory, Livermore, CA.

Gudiksen, P.H.; Harvey, T.F.; Lange, R. 1988. "Chernobyl source term, atmospheric dispersion, and dose estimation." In SCOPE-ENUWAR workshop on the environmental consequences of nuclear war. Lawrence Livermore National Lab., Livermore, CA, U.S.A.

Gudiksen, P.H.; Sullivan, T.J.; Harvey, T.F. 1987. "The current status of ARAC and its application to the Chernobyl event." IEEE Trans. Nucl. Sci. NS $-34(1): 584-589$.

Gulshani, P.; Dastur, A.R.; Chexal, B. 1987. "Stability analys is of spatial power distribution of the RBMK-100 reactor." Trans. Am. Nucl. Soc. $54: 383-386$.

Gummer, S.; Campbe11-Savours, D.N.; Maxwel1-Hyslop, R. 1987. "Food protection." Hansard, House Commons Off. Rep. 123(51):323-354.

Gumprecht, D.; Kindt, A. 1986. Consequences for the Federal Republic of Germany arising from the reactor accident at Chernobyl. Reconmendations of the Radiation Protection Commission (SSK) relating to risk assessment, jimitation, evaluation. Fischer, Stuttgart, Germany, F.R.

Gumprecht, D.; Kindt, A. (eds.). 1988. Impact of the Chernobyl nuclear power plant accident on the Federal Republic of Germany. Recommendations of the Commission on Radiological Protection: Assessment, limitation and valuation. Fischer, Stuttgart, Germany, F.R.

Gus'kova, A.K.; Baranov, A.E.; Barabanova, A.V. 1987. "Exposed persons at the Chernobyl Atomic Power Station accident: acute radiation effects." Med. Radiol. 32(12):3-18. 
Gustafsson, L. 1986. "Impact of the Chernobyl accident on Sweden." Nucl. Eur. $6(12): 28-29$.

Gysi, M. 1986. "No black and white answers." Schweiz. Tech. Z. 83(14):5.

Gysi, M. 1986. "Panic actions." Schweiz. Tech. Z. 83(11):7.

H. Aaltonen, et al. 1986. Interim Report on Fallout Situation in Finland from April 26 to May 4, 1986 Finnish Centre for Radiation and Nuclear Safety-Surveitlance Department, Helsinki.

H. Bonka. 1987. "Estimation of the Radiation Exposure of the Population Due to the Accident at Chernobyl" In Workshop on the Radiological Consequences of Chernobyl, Commission of European Communities. Rheinisch-Westfalische Technische Hochschule, Aachen, Federal Republic of Germany.

Haaland, L. 1986. "Danger is exaggerated." Tek. Ukebl. 133(37):14, 20-21.

Haberer, K. 1986. "Radioactivity and drinking water supply. Part 2. The contamination of air, rainfall and surface in Germany following the Chernobyl accident." GWF, Gas-Wasserfach 127(12):597-603.

Haberer, K. 1987. "Environmental radioactivity and water supply. Part 3. The contamination of surface waters in Germany after the Chernobyl reactor accident." GWF, Gas-Wasserfach 128(2): 123-127.

Haberer, K. 1987. "Environmental radioactivity and drinking water supply. Part 6 . Hazards, studies on incidents and the role of drinking water treatment." GWF, Gas-Wasserfach 128(7):396-403.

Haberer, K. 1987. "Environmental radioactivity and drinking water supply. Part 5. Water chain exposure from fallout after Chernobyl and after nuclear weapon tests." GWF, Gas-Wasserfach 128(6):342-353.

Haberer, K. 1986. "Environmental radioactivity and drinking water supply. Part 1. The Chernobyl reactor accident and its consequences." GWF, Gas-Wasserfach 127(11):529-532.

Haberer, K. 1987. "Radioactivity and drinking water supply. Part 7. Contamination of the environment and the radiation exposition to man." GWF, Gas-Wasserfach 128(9):488-496.

Haefele, W. 1987. "Fast breeder futures after Chernobyl." Energy Explor. Exploit. 5(5-6):415-434.

Haehlen, P.; Bucher, P. 1986. "Accident in the Russian nuclear power station Chernobyl-4: first report and technical background information. "Schweiz. Ver. Atomenerg., Bull. 28(g):19-26.

Haerle, W. 1986. What would getting over with nuclear energy mean? Getting in on responsibility. Neukirchener Verl., Neukirchen-Vluyn, Germany, F.R. 
Haga, T.; Shimegi, N.; Takabe, Y. 1987. "Probability of double nuclear bursts in the Chernobyl reactivity accident." In International seminar on nuclear criticality safety. CONF-871045, Japan Atomic Energy Research Inst., Tokai, Japan.

Hagen, U. 1986. "Radiation burden resulting from the Chernobyl accident." Brandschutz-Dtsch. Feuerwehrztg. 40(7):253-254.

Hagerman, Y. 1986. Occupational environment of mining, production and transport of certain fuels for power and heating plants. After Chernobyl. Statens Energiverk, Stockhoim, Sweden.

Haggin, J. 1986. "New era of inherently safe nuclear reactor technology nears." Chem. Eng. News p. 18-22.

Hajdukovicj, D.; Vukoticj, M. 1987. "External radiation exposure of population in Serbia due to the radioactive contamination after the Chernobyl accident." In 14. Yugoslav symposium on radiation protection. Yugoslav Radiological Protection Association, Novi Sad, Yugoslavia.

Hall, A. 1988. "Consensus growing on positive scram at Chernobyl." Nucl. Eng. Int. $33(402): 16,18-19$.

Hall, I.R.; MCGil1, P.R. 1988. "Chernobyl accident: monitoring for radioactivity in Scotland." CSO Stat. News 82:17-23.

Hallam, J.; Moore, C.; Broadbent, S. 1986. "Lessons from Chernobyl." Mov. Against Uranium Min. Newsl. P. 1-4.

Hamberg, A. 1987. "Long life reactors - design requirements." In Conference on nuclear risks - reassessing the principles and practical after Chernobyl. IBC Technical Services Ltd., London, U.K.

Hamberg. A. 1987. "Fifteen years of nuclear controversy in Sweden." ATW, Atomwirtsch., Atomtech. 32(8/9):447-450.

Hamilton, G. 1988. "Bulgarians believe in a nuclear solution." Energy Econ. 83:11-13.

Hamilton, L.D. 1986. "Environmental effects of radiation emergencies." In International conference on non-military radiation emergencies.

DOE/ER/60525-1, Brookhaven National Lab., Upton, NY, U.S.A.

Hamilton, M. 1986. "Chernobyl: a cloud over the media." Occup. Saf. Health $16(8): 18-20$.

Hamilton, M. 1986. "Chernobyl: would we get it right?" Occup. Saf. Health $16(8): 21-23$.

Hamman, H.; Parrott, S. 1987. Mayday at Chernobyl. One year on the facts revealed. New English Library, London, U.K. 
Hamstra, J. 1988. "Radiological consequences and reactions in Western Europe caused by the Chernobyl reactor accident as evidence to advocate reconsidering the present-day control of exposures to low-level ionising radiation." J. Radiol. Prot. B(1):47-50.

Hancock, R.; Woolam, P. 1987. "Chernobyl and the Slimbridge swans." Atom $373: 30-32$.

Hancock, R.; Woollam, P.B. 1987. Radioactivity measurements on live Bewick's Swans. Central Electricity Generating Board, Berkeley, U.K.

Hancock, R.; Woollam, P.B. 1987. Environmental radioactivity measurements at BNL during the year following the Chernobyl accident. CEGB-TPRD/B-0968/R87, Central Electricity Generating Board, Berkeley, U.K.

Hancock, R.; Woollam, P.B. 1988. "Environmental radioactivity measurements at Berkeley Nuclear Laboratories during the year following the Chernobyl accident." J. Radiol. Prot. 8(3):139-148.

Handl, J.; Pfau, A. 1986. "Inventory taking and transfer of I-129 in the food chain and fission product transfer on the pathway pasture-dairy cow-milk. An assessinent of the situation after the Chernobyl accident." In CEC contractors meeting on the environmental transfer of radionuclides: implications of Chernobyl on terrestrial and aquatic ecosystems. Niedersaechsisches Inst. fuer Radiooekologie, Hanover, Germany, F.R.

Hand1, J.: Pfau, A. 1987. "Feed-milk transfer of fission products following the Chernobyl accident." Atomkernenerg. Kerntech. 49(3):171-173.

Haque, F. 1987. "Food contamination: Lessons of Chernoby1." Curr. Aff. Bull. $64(7): 22-26$.

Harding, C.G.F. 1988. "Future of nuclear energy in western industrialised nations." ATW, Atomwirtsch., Atomtech. 33(11):543-546.

Hardy, E.; Krey, P.; Klusek, C.; Miller, K.; Helfer, I.; Sanderson, C.; Rivera, W. 1986. Observations and sampling by EML in Sweden, with prel iminary gamma-ray spectrometric data. Volchok, H.L.; Chieco, N. (eds.), USDOE Environmental Measurements Lab., New York, NY, U.S.A.

Hauck, D. 1986. "After the Chernobyl reactor accident: Just got away." Ther. Gegenw. 27:14-17.

Haunold, E. 1987. Seiberdorf scientists give answers to questions in connection with the Chernoby reactor accident. Oesterreichisches Forschungszentrum Seibersdorf G.m.b.H., Vienna, Austria.

Haunold, E. 1986. "What to do with radioactively contaminated soils. The behavoir of radionuclides in the soil-plant system." Blick Land 21(7):10-11. 
Haunold, E.; Horak, 0.; Gerzabek, M. 1986. Environmental radioactivity and its impact on agriculture. I. The behaviour of radionuclides in soils and plants. Oesterreichisches Forschungszentrum Seibersdorf G.m.b.H., Vienna, Austria.

Haury, H.J.; Klenm, C. 1986. "Radiation protection, a topical subject due to the Chernobyl disaster: Questions and answers." Brandschutz-0tsch. Feuerwehrztg. $40(7): 255-256$.

Haury, H.J.; Ullmann, C. 1986. Life after Chernobyl. Radiation burden radiation effects - risks. List, Muenchen, Germany, F.R.

Have1, S. 1987. "Nuclear power today and tomorrow." Mezhdunar. Agentstvo At. Ehnergii Byul1. 29(1):38-40.

Havel, S. 1987. "Report from Czechoslovakia: Nuclear power today and tomorrow. An update of operations and plans." IAEA Bul1. 29(1):32-33.

Hawickhorst, W.; Gremm, 0.; Orth, K. 1987. "Experience with the statutory licensing procedure; historical development and future structure."

Kerntechnik 50(4):288-293.

Hawkes, N.; Lean, G.: Leigh, 0.; Mc Kie, R.; Pringle, P.; Wilson, A. 1987. Chernobyl: The end of the nuclear dream. Random House Inc., New York, NY, U.S.A.

Hawkes, N.; Lean, G.; Leigh, D.; McKie R.; Pringle, P.; Wilson, A. 1986. Chernobyl: The worst accident in the world. Presses de la Cite, Paris, France.

Hawkes, N.; Lean, G.; Leigh, D.; McXie, R.; Pringle, P.; Wilson, A. 1986. Worst accident in the world. Chernobyl: the end of the nuclear dream. Pan Books Ltd., London, U.K.

Haynes, V.; Bojcun, M. 1988. Chernobyl disaster. Hogarth Press, London, U.K.

Hayns, M.R.: Phillips, 0.W. 1988. "Safety principles for advanced plant." In International approach to nuclear safety seminar. Ballard, G.M. (ed.), CONF-8806174, Elsevier Applied Science, London, U.K.

Haywood, J.K. 1986. Chernobyl: response of medical physics departments in the United Kingdom. Institute of Physical Sciences in Medicine, London, U.K.

Haywood, J.K. 1986. IPSM survey of monitoring by Medical Physics Departments. Haywood, J.K. (ed.), Institute of Physical Sciences in Medicine, London, U.K.

Haywood, J.K.; Boddy, K. 1986. General discussion. Haywood, J.K. (ed.), Institute of Physical Sciences in Medicine, London, U.K. 
Hazleton-Nuclear Science Corp. 1986. Spain's radiological observation after the accident at the Chernobyl nuclear power station. Preliminary report, Phase 1 (28th April to 4th May, inclusive). Hazleton-Nuclear Science Corp., Palo Alto, CA, U.S.A.

Health and Safety Commission. 1987. Advisory committee on the safety of nuclear installations report 1984-1986. H.M. Stationery Office, London, U.K.

Hecht, H. 1987. "Estimation of the radioactive contamination of the vegetation and the transfer of radionuclides from plants into meat." Dtsch. Tieraerztl. Wochenschr. 94(6):361-364.

Heck, C.L.; Hochreiter, L.E.; Huang, P.; Stolmar, A. 1987. "Analys is of the Chernobyl accident." Trans. Am. Nucl. Soc. 54:221-222.

Heeb, C.M.; Lotz, T.L.; Doherty, A.L. 1987. "Three-dimensional diffusion theory model of Chernobyl-4." Trans. Am. Nucl. Soc. 54:382-383.

Hehn, G.; Mueller, T. 1987. "Detailed study of radiation exposure in Baden-Wuerttemberg due to the Chernobyl reactor accident." In Annual meeting on nuclear technology. Deutsches Atomforum e.V., Bonn, Germany, F.R.

Heidinger, P.F. 1986. "Responsible ways of energy supply." At. Stron $32(6): 187-191$.

Heijboer, R.J. 1986. "Questions about the reactor accident with Chernobyl-4." Energiespectrum 1D(6-7):129-134.

Heilmann, K. 1986. Chernobyl - a challenge to reason. Edition Agrippa, Koeln, Germany, F.R.

Heilmann, K. 1986. "Risk assessment in an industrial society: the case of nuclear energy." In SVA information meeting on safety of nuclear power plants in the light of TMI and Chernobyl. Schweizerische Vereinigung fuer Atomenergie, Bern, Switzerland.

Heinloth, K. 1987. "Careful choice among all available energy sources. The risk of fossil fuels urge upon the planning of a new energy scenario." Phys. Unserer Zeit 18(2):47-51.

Heinrich, G. 1987. Radioactive burden of plants in Graz after the Chernobyl accident. Gepp, J.; Teich, T. (eds.), Graz Univ., Graz, Austria.

Heinrich, M.: Schmidt, A. 1986. Nuclear atlas. After Chernobyl: Nuclear energy between fear and hope. Figures - facts - background information. Heyne, Muenchen, Germany, F.R.

Heinz, S. 1988. "Consumer and media viewpoint." Health Phys. 55(2):357-360. 
Hellmuth, K.H. 1987. Rapid determination of strontium-89 and strontium-90. Experiences and results with various methods after Chernobyl accidnet in 1986. STUK-A-70, Finnish Centre for Radiation and Nuclear Safety, Helsinki, Finland.

Helsedirektoratet. 1986. Radioactive fallout over Norway after the reactor accident in USSR. Radioactivity in foodstuffs 1986. Helsedirektoratet, 0s 10 , Norway.

Hennicke, P. 1986. "After Chernobyl: Energy concepts are more important than ever before." Z. Energiewirtsch. 10(3):196-201.

Hennies, H.H. 1986. "On the sequence and consequences of the Chernobyl reactor accident." KFK-Nachr. 18(3):127-132.

Hennies, H.H. 1986. "Safety research and prevention of accidents: nuclear safety technology." In SVA information meeting on safety of nuclear power plants in the light of TMI and Chernobyl. Schwejzerische Vereinigung fuer Atomenergie, Bern, Switzerland.

Hennies, H.H. 1986. "On the course of the reactor accident at Chernobyl and on its transferability to German nuclear plants." In Colloquium of the Projekt Nukleare Sicherheit (PNS) of the Kernforschungszentrum Karlsruhe G.m.b.H. Kernforschungszentrum Karlsruhe G.m.b.H., Germany, F.R.

Hennies, H.H. 1986. "Radiation measurements in Germany resulting from the Chernobyl accident." Nucl. Eur. 6(7/8):22-25.

Hennies, H.H. 1986. "Chernobyl accident: Man or machine?" Nucl. Eur. 6(11):7. Hennies, H.H. 1986. "History, consequences and evaluation of the Chernobyl reactor accident." VGB Kraftwerkstech. 66(10):902-909.

Hennies, H.H.; Kessler, G.; Kuczera, B. 1987. "Reactor safety research and safety technology. Part. 1. Reactor safety research for light water reactors (LWR's)." In AGF congress on Chernobyl and the future of energy supply in the Federal Republic of Germany. Kernforschungszentrum Karlsruhe G.m.b.H., Germany, F.R.

Henrich, E. 1988. "Chernobyl - its impact on Austria." Sci. Total Environ. $70: 70$.

Henrie, J.0.; Postma, A.K. 1987. "Hydrogen generation during the TMI-2 and Chernobyl events." Irans. Am. Nucl. Soc. 54:225-226.

Henriksen, T.; Saxeboel, G. 1987. Fallout and radiation doses in Norway after the Chernobyl accident. Fysisk Inst., 0sio, Norway.

Herbert, R. 1987. "Chernobyl: how the cover was blown." New Sci. 114 (1557) : 34-36. 
Hering, E.; Schulz, W. 1987. Nuclear power plants, radioactivity and radiation effects. VDI-Ver1., Duesseldorf, Germany, F.R.

Hermann, A.; Schumacher, R. (eds.). 1987. Nuclear energy - beginning or end of an era. A factual and critical documentation. Moos, Muenchen, Germany, F.R.

Herzog, T. 1986. "Effects of large-area contamination through the Chernobyl reactor accident on the operation of nuclear power plants." Gesund.-Ing. $107(5): 290-293$.

Hessisches Sozialministerium. 1987. Chernobyl reactor accident and its consequences. (3rd Edition). Hess isches Soziatministerium, Wiesbaden, Germany, F.R.

Hettling, H.K. 1987. Radioactivity after 'Chernobyl'. Cesium spread in Dutch waters caused by the 'Chernobyl' accident: first results and adapted research program. Rijkswaterstaat, Lelystad, Netherlands.

Heuser, F.W. 1987. "Main results of the German risk study - phase B." In Seminar concerning safety studies on severe accident in light water reactors. EUR-11019, Gesellschaft fuer Reaktorsicherheit (GRS), Koeln, Germany, F.R.

Hicken, E. 1986. "Explosions and fires. Still no precise information on the causes of the accident in the Soviet reactor at Chernobyl." Energiewirtsch. Tages fragen $36(7): 546-548$.

Hicken, E. 1986. "Chernobyl reactor accident: First evaluation of the Soviet report." ATW, Atomwirtsch., Atomtech. 31(10):486-488.

Hicken, E. 1986. "Chernobyl report from the USSR. Latest information concerning the accident and its causes." Energiewirtsch. Tagesfragen $36(9): 683-687$.

Hicken, E.F.; Hicks, D.; MC Pherson, G.D. 1986. "Results from the LOFT international programme." In SVA information meeting on safety of nuclear power plants in the light of TMI and Chernobyl. Schweizerische Vereinigung fuer Atomenergie, Bern, Switzerland.

Higson, D.J. 1987. "Probabilistic safety criteria for nuclear reactors and other potentially hazardous installations." Radiat. Prot. Aust. 5(2):41-48.

Higuchi, H.; Fukatsu, H.; Hashimoto, T.; Nonaka, N.; Yoshimizu, K.; et al. 1988. "Radioactivity in surface air and precipitation in Japan after the Chernobyl accident." J. Environ. Radioact. 6(2):131-144.

Hill, C.R.; Adam, I.; Anderson, W.; Ott, R.J.; Sowby, F.D. 1986. "Iodine-131 in human thyroids in Britain following Chernobyl." Nature 321(6071):655-656.

Hill, C.R.; Bowlt, C. 1988. "Thyroid dose from I-131 in the UK following Chernobyl; and reply." J. Radiol. Prot. 8(2):118. 
Hill, M.D. 1987. "Chernobyl - the radiological consequences in the USSR." In 'Chernobyl - a technical appraisa]' seminar. British Nuclear Energy Society, London, U.K.

Hill, M.D. 1987. "Assessment of the radiological impact of the Chernobyl accident in Europe." Radiol. Prot. Bull. 83:13-14.

Hirsch, H. 1986. "Next accident is sure to come. None of our reactors is safe enough." Zeit 41(43):41-42.

Hisamatsu, S.; Takizawa, Y.; Abe, T. 1987. "Reduction of $1-131$ content in leafy vegetables and seaweed by cooking." Radiat. Res. 28(1):135-140.

Hodgson, P.E. 1987. "Rational and reasonable in the field of nuclear energy." Rev. Quest. Sci. 158(1):33-66.

Hoegberg, L. 1987. "Chernobyl accident and its implications for reactor safety in OECD countries." News 1. NEA Data Bank 5(1):9-11.

Hoelgye, Z.: Filgas, R. 1987. "Determination of Pu-239 + Pu-240 in surface air in several localities in Czechoslovakia in 1986 in connection with the Chernobyl radiation accident." J. Radioanal. Nucl. Chem. 119(1):21-28.

Hoest, J. 1986. NGU's follow-up after the Chernobyl accident and their utilitarian value in future preparedness. Norges Geologiske Undersoekelse, osto, Norway.

Hoetz1, H.; Rosner, G.; Winkler, R. 1987. "Ground depositions and air concentrations of Chernobyl fallout radionuclides at Munich-Neuherberg." Radiochim. Acta $41(4): 181-190$.

Hofer, P. 1987. "Swiss Association for Atomic Energy information meeting: Radiation in the light of Chernobyl." Bul1. Schweiz. Elektrotech. Ver. $78(10): 579$.

Hoffman, F.0. 1987. "Modelling approaches for estimating derived intervention levels in foods." In Scientific seminar on foodstuff intervention levels following a nuclear accident. Oak Ridge National Lab., Oak Ridge, TN, U.S.A.

Hoffman, F.0.; Amaral, E.; Mohrbacher, D.A.; Deming, E.J. 1988. "Comparison of generic model predictions with Chernobyl fallout data on the transfer of radioiodine over the air-pasture-cow-milk pathway." J. Environ. Radioact. $8(1): 53-71$.

Hoffmann, E.P. 1986. "Nuclear deception: soviet information policy." Bull. At. Sci. $43(1): 32-37$.

Hoffmann, P.; Pilz, N.; Lieser, K.H.; Ilmstaedter, V.; et al. 1987.

"Radionuclides from the Chernobyl accident in the environment of Chattia, a region of the FRG." Radiochim. Acta 41(4):173-179. 
Hofmann, W.; Crawford-Brown, D.J.; Martonen, T.B. 1988. "Radiological significance of beta emitting hot particles released from the Chernobyl nuclear power plant." Radiat. Prot. Dosim. 22(3):149-157.

Hogan, R.; McKenna, T. 1987. "Results of the early NRC analyses of the radiological monitoring data from the Chernobyl accident." In Radiological accidents, perspectives and emergency planning preparedness. Nuclear Regulatory Comission, Washington, D.C., U.S.A.

Hohenemser, C.: Deicher, M.; Ernst, A.; Hofsaess, H.: Lindner, G.; Recknagel, E. 1986. "Chernobyl: an early report." Environment 28(5):6-13, 30-43.

Hohenemser, C.; Deicher, M.; Hofsaess, H.; Lindner, G.; Recknagel, E.; Budnick, J.I. 1986. "Agricultural impact of Chernobyl: a warning." Nature $321(6073): 817$.

Hohenemser, C.: Renn, 0. 1988. "Chernobyl's other legacy." Environment $30(3): 4-11,40-45$.

Holdt, C.S. 1987. Experiments on the reduction of radiocesium in pigs by adding clay minerals to the contaminated feed. Veterinaermedizinische Univ. , Vienna, Austría.

Holliday, B.; Binns, K.C.; Stewart, S.P. 1986. "Monitoring Minsk and Kieve students after Chernobyl." Nature 321(6073):820-821.

Holloway, N. 1988. "Significance of human actions for plant safety." Atom $379: 2-7$.

Holloway, N.J. 1988. "Past PSA studies and applications." In International approach to nuclear safety seminar. Ballard, G.M. (ed.), CONF-8806174, Elsevier Applied Science, London, U.K.

Holmberg, M.; Edvarson, K.; Finck, R. 1988. "Radiation doses in Sweden resulting from the Chernobyl fallout: a review." Int. J. Radiat. Biol. $54(2): 15 i-166$.

Holmes, A. 1986. Electricity in Europe. Present status and prospects for the 1990s. Financial Times Business Information Ltd., London, U.K.

Holmes, A. 1987. Changing climate. Environmentalism and its impact on the European energy industries. Financial Times Business Information Ltd., London, U.K.

Holmes, A. 1986. "Chernobyl - the ratchet turns again on safety and economics." Energy Econ. 56:2-6.

Holt, P. 1986. "ENC '86: Chernobyl and the tasks ahead." Nucl. Eur. $6(7 / 8): 35-39$.

Holt, P. 1987. "Health impact of Chernobyl. An interview with Dr. Robert Gale." Nucl. Eur. 7(5):42-43. 
Holzer, J. 1986. "Energy policy after Chernobyl. Statement on a panel discussion." Elektrizitaetswirtschaft 86(22):877-879.

Honma, S.; Takahashi, T.; Yamagaki, K. 1988. "Radioactive contamination of the service water in Niigata City due to the Chernobyl nuclear accident and the experiment of radioactivity removal with active carbon." Suido Kyokai Zasshi $57(1): 24-29$.

Hoogcarspe1, B.B. 1986. "Chernobyl: a lesson for the future." $\underline{\mathrm{H} 20}$ $19(25): 610-614$.

Hopff, W. 1986. "Man and environment: interactions and limits." In SVA information meeting on safety of nuclear power plants in the light of TMI and Chernobyl. Schweizerische Vereinigung fuer Atomenergie, Bern, Switzerland.

Hoppenau, S. 1986. "Increase of soil radioactivity in Cologne as a consequence of the Chernobyl reactor accident." Prax. Naturwiss. Phys. $35(7): 43-46$.

Horak, 0. 1986. "Radioactive uptake by plants." Agro Zucker 4:4.

Horak, 0. 1986. Contribution to the topic 'environmental radioactivity'. Oesterreichisches Forschungszentrum Seibersdorf G.m.b.H., Vienna, Austria.

Horak, 0. 1986. Chernobyl reactor accident and its impact on Austrian agriculture. Desterreichisches Forschungszentrum Seibersdorf G.m.b.H., Vienna, Austria.

Horak, 0.: Gerzabek, M. 1988. Bas is data for the regional prognosis of the human radiation burden by the model ECOSYS. 1st preliminary report: Estimation of the soil deposition of Cs-137 by the Tschernobyl accident/Literature review about transfer factors. 0EFZS-4447, Desterreichisches Forschungszentrum Seibersdorf G.m.b.H., Vienna, Austria.

Horin, A. 1986. "Ten thousand cancers: counting the cost of Chernobyl. The first meltdown." Nat1. Times 798:25-28.

Horn, H. 1986. "Ruhrkohle AG: 1985-1986." Glueckauf 122(15):1008-1011.

Horn, H.-G.; Bonka, H.; Maqua, M. 1987. "Measured particle bound activity size-distribution, deposition velocity, and activity concentration in rainwater after the Chernobyl accident." J. Aerosol Sci. 18(6):681-684.

Horn, M. 1987. "Reform in the power regulation in the USA. Can it be a model for the Federal Republic of Gemany?" Energiewirtsch. Tagesfragen $37(10): 838-841$.

Horyna, J.; Kucera, J.; Posta, S.; Tomasek, M.; Rybacek, K.; Wilhelmova, L. 1987. "Atmospheric radiactivity in Prague and escape of radioactivity from Chernobyl nuclear power plant." Jad. Energ. $33(8-9): 343-344$. 
Horyna, J.; Wilhelmova, L. 1988. "Time evolution of the airborne radioactivity in Rez related to the activity release rate in Chernobyl." $\mathrm{J}_{\text {. }}$ Radioanal. Nucl. Chem. 126(4):307-314.

Hosemann, G.; Wirth, E. (eds.). 1987. Natural and artificial radioactivity in the environment. A stocktaking before and after Chernobyl. INIS-mf-11696, Universitaetsbund Erlangen-Nuernberg e.V., Erlangen, Germany, F.R.

Hosemann, J.P.; Fuchs, H. 1986. "Source terms: new experiments, models, calculations, results and their applications." In SVA information meet ing on safety of nuclear power plants in the light of TMI and Chernobyl. Schweizerische Vereinigung fuer Atomenergie, Bern, Switzerland.

House of Commons. 1988. Chernobyl: the Government's reaction. V.1. Report and proceedings of the Committee. H.M. Stationery Office, London, U.K.

House of Lords. 1986. Nuclear power in Europe. V.1. Report. Session 1985-86, 18th report. H.M. Stationary Office, London, U.K.

Howald, K. 1986. "Emergency planning as illustrated by the Kanton of Solothurn." In SVA information meeting on safety of nuclear power plants in the light of TMI and Chernobyl. Schweizerische Vereinigung fuer Atomenergie, Bern, Switzerland.

Howard, B.; Livens, F. 1987. "May sheep safely graze." New Sci. $114(1557): 46-49$.

Howard, B.J.; Beresford, N.A.; Burrow, L.; Shaw, P.V.; Curtis, E.J.C. 1987. "Comparison of caesium 137 and 134 activity in sheep remaining on upland areas contaminated by Chernobyl fallout with those removed to less active lowland pasture." J. Soc. Radiol. Prot. 7(2):71-73.

Hubacher, H.; Kohn, M. 1986. "Abandonment of atomic energy. An interesting exchange of letters." Bull. Assoc. Suisse Electr. $77(20): 1330-1333$.

Huber, E.E.; Dersee, T.; Iwert, B. 1986. Chernobyl - an evaluation of health hazards. (3rd Edition) Fraktion Gesundheit in der Aerztekammer, Berlin, Germany, F.R.

Hudson, A.P.; Bailey, M.R. 1988. "Chernobyl caesium in Yorkshire." Radiol. Prot. Bu11. 89:9-12.

Hughes, J.S.; Shaw, K.B. 1986. "Radiation monitoring of conveyances, cargoes, passengers and crews on the UK following the Chernobyl accident: a preliminary review." Radiat. Prot. Dosim. 15(3):207-210.

Hughes, M.G.; Ali, P.A.; Birks, J.L.; Morgan, W.D.; Woodward, A.F.; Sivyer, A.; Haywood, J.K. 1986. Environmental measurements in the Swansea area.

Institute of Physical Sciences in Medicine, London, U.K. 
Hu11, A.P. 1987. "Preliminary dose assessment of the Chernobyl accident." In American Nuclear Society annual meeting. Brookhaven National Lab., Upton, NY, U.S.A.

Humphreys, P. 1988. "Strategies for man-machine interactions analysis in PSA." In International approach to nuclear safety seminar. Ballard, G.M. (ed.), CoNF-8806174, Elsevier Applied Science, London, U.K.

Hundeiker, M. 1987. "Clinical picture of delayed radiation effects in the skin." In 27. annual conference of Vereinigung Deutscher Strahlenschutzaerzte e.V. Schuetz, J.; Boerner, W.; Messerschmidt, 0. (eds.), CONF-8605338, Thieme, Stuttgart, Germany, F.R.

Hunnius, G. 1987. "Image of the power econony in the public eye 1986/1987." Elektrizitaetswirtschaft 86(16/17):727-732.

Hunt, G.J. 1987. Radioactivity in surface and coastal waters of the British Isles, 1986. Ministry of Agriculture, Fisheries and Food, Lowesoft, U.K.

Hunt, S.E. 1987. Nuclear physics for engineers and scientists: Low energy theory with applications including reactors and their environmental impact. John Wiley and Sons Inc., New York, NY, U.S.A.

IAEA. 1986. Nuclear safety review for 1985. IAEA, Vienna, Austria.

IAEA. 1986. Summary report on the post-accident review meeting on the Chernobyl accident. Report by the International Nuclear Safety Advisory Group. IAEA, Vienna, Austria.

IAEA. 1987. Nuclear safety review for 1986. IAEA, Vienna, Austria.

IAEA. 1988. Nuclear safety review for 1987. IAEA, Vienna, Austria.

IAEA. 1987. One year after Chernoby 1. IAEA, Vienna, Austria.

IAEA. 1986. Documents, used for drawing up the CCRX-report 'Radioactive contamination in the Netherlands caused by the reactor accident at Chernobyl'. Part 1. IAEA, Vienna, Austria.

1AEA. 1986. Letter from Mr. M. Gorbachev, General Secretary of the Central Committee of the Communist Party of the Soviet Union, to Or. H. Blix, Director General of the Agency. IAEA, Vienna, Austria.

IAEA. 1987. Documents used for drawing up the CCRX-report 'Radioactive contamination in the Netherlands caused by the reactor accident at Chernobyl'. Part 2. IAEA, Vienna, Austria.

IAEA. 1987. One year after Chernobyl - the world has changed. IAEA, Vienna, Austria. 
IAEA. 1988. Dose assessments in nuclear power plant siting. User's manual within the framework of the Nuclear Safety Standards (NUSS) programe. IAEA-TECDOC-450, IAEA, Vienna, Austria.

IAEA. 1986. Statement issued on 5 May 1986 by the Heads of State or Government of seven major industrial nations and the Representatives of the European Community. IAEA, Vienna, Austria.

IPSN. 1986. The Chernobyl Accident Comnissariat a 1 'Energie Atomique Institut de Protection et de Suret Nuclaire, Fontenay-aux-Roses.

IRP. 1986. Ergebnisse von Radioaktivittsmessungen nach dem Reaktonunfall in Ischernobyl Institute for Radiation Protection-Munich-Neuherberg, Munich.

Ichikawa, R. 1987. "Effects on environment and humans of accident of Chernobyl nuclear power plant." Nippon Genshiryoku Gakkaishi 29(1):15-17.

I ijima, T. 1986. Environmental Surveillance in Japan Related to Chernobyl Reactor Accident Japan Atomic Energy Research Institute, Ibaraki-Ken.

Ikaeheimonen, T.; Ilus, E.; Saxen, R. 1988. Finnish studies on radioactivity in the Baltic Sea in 1987. Supplement 8 to Annual Report 1987 STUK-A--74. STUK-A-82, Finnish Centre for Radiation and Nuclear Safety, Helsinki, Finland.

Il'in, L.A.; Pavlovskij, 0.A. 1988. "Radiological consequences of the Chernobyl accident in the Soviet Union and measures taken to mitigate their impact." In International conference on nuclear power performance and safety. CONF-8709263, IAEA, Vienna, Austria.

Illish, A. 1987. Chernobyl eyewitness. Richardson and Steiman, New York, NY, U.S.A.

Ilus, E.; Sjoeblom, K.L.; Aaltonen, H.; Klemola, S.; Arvela, H. 1987. Monitoring of radioactivity in the environs of Finnish nuclear power stations in 1986. Supplement 12 to annual report STUK-A55. Finnish Centre for Radiation and Nuclear Safety, Helsinki, Finland.

Ilus, E.; Sjoeblom, K.L.; Saxen, R.; Aaltonen, H.; Taipale, T.K. 1987. Finnish studies on radioactivity in the Baltic Sea after the Chernobyl accident. Supplement to Annual Report STUK-A55. Finnish Centre for Radiation and Nuclear Safety, Helsinki, Finland.

Imanaka, T.: Koide, H. 1986. "Fallout in Japan from Chernoby1." J. Environ. Radioact. 4(2):149-153.

Imhoff, K.R.; Koppe, P.; Dietz, F. 1988. "Investigations on the concentration of radionuclides in sewage sludges of Ruhrverband wastewater treatment plants 1960 through to 1986." Water Res. 22(8):1059-1067.

Ince, M. 1988. Secrecy, policy-making and the nuclear state. M.; Mackay, L.; Thompson, M. (eds.), Pluto Press, London, U.K. 
Ingrao, G.; LaBrecque, J.J.; Schelenz, R.; Perkins, R.W. 1987. "Short summary of the activities in Italy after the Chernobyl nuclear accident." In Consultants meeting on the determination of radionuclides in grass ecosystem samples. IAEA, Seibersdorf, Austria.

Ingrao, G.; Santaroni, G.P. 1987. "Cesium levels in some Italian diets before and after the Chernobyl accident." In 21. annual conference on trace substances in environmental health. Hemphil,, D.D. (ed.), CoNF-8705217, University of Missouri, Columbia, MO, U.S.A.

Institut fuer Dokumentation und Information ueber Sozialmedizin und Oeffentliche. 1987. Radioactivity. Part. 2. A selected bibliography of documents dealing with environmental radioactivity one year after the Chernobyl reactor accident. Institut fuer Dokumentation und Information ueber Sozialmedizin und oeffentTiche, Germany, F.R.

Institution of Professional Civil Servants. 1986. Review of energy policy. Vol. 1. A discussion paper: Vol. 2. Appendices. Institution of Professional Civil Servants, London, U.K.

Internationale Gewaesserschutzkommission fuer den Bodensee. 1987. Radioactivity measurements in the Lake of Constance after the Chernoby reactor accident. INIS-mf-11796, Internationale Gewaesserschutzkommission fuer den Bodensee, Germany, F.R.

Ise, T. 1987. "Inherently safe light water reactors." In 4. seminar on software in nuclear energy research. Fujii, M.; Osugi, T; Harada, H.; Ise, T. (eds.), Japan Atomic Energy Research Inst., Tokai, Japan.

Ishida, J.; Miyagawa, N.; Watanabe, H.: Asano, T.: Kitahara, Y. 1988. "Environmental radioactivity around Tokai-Works after the reactor accident at Chernobyl." J. Environ. Radioact. 7(1):17-27.

Ishikawa, M.; Shiozawa, S.; Onishi, N.; Wakabayashi, T.; Mochizuki, H. 1986. "Consideration on accident scenario in Chernobyl nuclear power station." Genshiryoku Kogyo 32(12):17-31.

Ishikawa, M.; Shiozawa, S.; Wakabayashi, T.; Ohnishi, N.; Mochizuki, H. 1987. "An examination of the accident scenario in the Chernoby 1 Nuclear Power Station." Nucl. Saf. 28(4):448-454.

Islam, S.: Lindgren, K. 1986. "How many reactor accidents will there be?" Nature 322(6081):691-692.

Israelsson, S.; Knudsen, E. 1986. "Effects of radioactive fallout from a nuclear power plant accident on electrical parameters." J. Geophys. Res. 91 (D11) : 11909-11910.

Israelsson, S.; Schuette, T.; Pisler, E.; Lundquist, S. 1987. "Increased occurrence of lightning flashes in Sweden during 1986." J. Geophys. Res. $92(09)$ : 10996-10998. 
Ivens, R.; Lablans, W.N.; Hessels, H.R.A. 1987. Meteorological circumstances during the 'Chernobyl-period'. Document 3. Koninklijk Nederlands Meteorologisch Inst., De Bilt, Netherlands.

Iwashima, K.; Okubo, T. 1987. "On the interim radionuclide action level for monitoring imported foods." Shokuhin Eisei Kenkyu 37(7):7-21.

Izraeh1', Yu.A.; Petrov, V.N.; Severov, D.A. 1987. "Simulation of radioactive fallout in the vicinity of Chernobyl" nuclear power plant accident." Meteorol. Gidrol. 7:5-12.

Jackson, D.; Jones, S.R.; Fulker, M.J.; Coverdale, N.G.M. 1987.

"Environmental monitoring in the vicinity of Sellafield following deposition of radioactivity from the Chernobyl accident." J. Soc. Radiol. Prot. $7(2): 75-87$.

Jackson, G.D. 1987. An interim report to the manager of the Paducah Gaseous Diffusion Plant from the Paducah Environmental Advisory Committee. Paducah Gaseous Diffusion Plant, KY, U.S.A.

Jacob, P.; Meckbach, R.; Mueller, H.M. 1987. "Reduction of external exposure from deposited Chernobyl activity by run-off, weathering, street cleaning and migration in the soil." Radiat. Prot. Dosim. 21(1-3):51-57.

Jacobi, W. 1986. Environmental Radioactivity and Radiation Exposure in South Bavaria Following the Chernobyl Accident Institute for Radiat. Protect. of the Society for Radiat, and Environ. Research, Munich-Neuherberg.

Jacobi, W. 1986. "Standard values and recomendations of the Radiation Protection Commission." Gesund.-Ing. 107(5):259-263.

Jacquish, R.E.; Mitche11, P.J. (eds.). 1988. Environmental monitoring at Hanford for 1987. PNL-6464, Pacific Northwest Lab., Richland, WA, U.S.A.

Jaeckle, R. 1986. Is there no reason to worry? The nuclear lobby and the MCA. Mosaik Verl., Muenchen, Germany, F.R.

Jaenecke, H. 1987. My God, what have we done? From Hiroshima to Chernobyl our way into nuclear disaster. Gruner und Jahr, Hamburg, Germany, F.R.

Jaenicke, M.; Mez, L.; Spelthahn, S.; Springmann, F.; Theissen, A.; Ullrich, 0.; Leuchtner, J. 1986. Qualitative and, as far as possible, quantitative assessment of the short-term and long-term effect of a nuclear phase-out. Inst itut fuer 0ekologische Wirtschaftsforschung (IOEW) G.m.b.H., Berlin, Germany.

Jagielak, J.; Pietruszewski, A.; Woloszyn, Z.; Zawanowski, K.; Garlinski, K.; Kozub, M. 1987. "Effective dose equivalent to average individuals in Warsaw after the Chernobyl accident." Radiat. Prot. Dosim. 20(4):243-247. 
Jahr, R. 1986. "Measuring units and quantities applied in radiation protection monitoring." PTB-Mitt. 96(4):249-251.

James, M. 1986. "Who wants a nuke after Chernobyl?" Sierra 71(6):76-78.

James, N.; Sheppard, G.; Williams, R. 1987. "THORP and the safety case." Chem. Eng. 434:17-21.

Janitschek, F. 1986. "Chernobyl reactor accident. Effects, preventive measures and conclusions." Oesterr. Z. Elektrizitaetswirtsch.

39(12):A168-A169.

Janitschek, F. 1986. "Radioactivity in agriculture." Oesterr. Z.

Elektrizitaetswirtsch. 39(12):A171.

Janjtschek, F. 1988. "Reactor accident at the Chernobyl nuclear power plant-Block 4. Effects, countermeasures and consequences." Oesterr. Ing.Archit.-Z. $133(2): 68-74$.

Janitschek, F.; Nistler, W. 1987. "On the anniversary of Chernobyl: comparison of Zwentendorf with Chernobyl." Oesterr. Ing.- Archit.-Z. $132(4): 101-106$.

Jankowski, M.W.; Powers, D.A.; Kress, T.S. 1987. "Onsite response to the accident at Chernobyl (accident management)." Nucl. Saf. 28(1):36-42.

Janssen, L.G.J. 1987. "Limitation of radioactive excursions by the containment construction. Chapter 14." In How can the engineer minimize the risks of nuclear power plants?. Van Loon, A.J. (ed.), KIVI-Kerntechniek, Arnhem, Netherlands.

Janssen, L.G.J. 1986. "Consequences of containment buildings to reactor safety." Energiespectrum 10(6-7):135-139.

Japan Atomic Energy Research Inst. 1987. Progress of nuclear safety research, 1987. Japan Atomic Energy Research Inst., Tokyo, Japan.

Japan Atomic Energy Research Inst. 1987. Health physics in JAERI. No.29. ApriT 1, 1986 - March 31, 1987. Japan Atomíc Energy Research Inst., Tokyo, Japan.

Japan Atomic Energy Research Inst. 1987. Report of the Ad hoc Committee on the Chernobyl Accjdent. Japan Atomic Energy Research Inst., Tokyo, Japan.

Japan Atomic Industrial Forum, Inc. 1986. Nuclear power plants in the world as of June 30, 1986. Japan Atomic Industrial Forum, Inc., Tokyo, Japan.

Jaworowski, Z. 1986. "National report: Poland. The first four weeks." IAEA Bu11. $28(3): 33-34$. 
Jaworowski, Z. and Kownacka, L. 1986. Tropospheric and Stratospheric

Distribution of Radionuclides After Chernobyl Accident Central Laboratory for Radiological Protection Report, Warsaw.

Jaworowski, Z.; Kownacka, L. 1988. "Tropospheric and stratospheric distributions of radjoactive jodine and cesium after the Chernobyl accident." J. Environ. Radioact. 6(2):145-150.

Jeffery, J.W. 1987. "Sizewell Report: A foregone decision." Ecologist $17(2-3): 102-107$.

Jennings, B. 1987. "HinkTey revisited." SCRAM: Anti-Nucl. Safe Energy J. $57: 7$.

Jennings, P. 1987. "Message from Chernobyl. A review of the AAEC report 'the Chernobyl nuclear accident and its consequences'." Aust. Phys. 24(3):66.

Jensen, M.; Lindhe, J.C. 1986. "National report: Sweden. Monitoring the fallout." IAEA Bull. 28(3):30-32.

Joerges, H.U. 1986. "Block on the Rhine - a domino. Kalkar: The uncertain future of the fast breeder. Getting out of the fast breeder project would change the whole nuclear industry." Sueddtsch. Ztg. 42(142):3.

Jones, B.E.: Millington, H.T.; Haywood, J.K. 1986. Radioactive contamination of travellers from Eastern Europe. Institute of Physical Sciences in Medicine, London, U.K.

Jones, G.D.; Forsyth, P.D.; Appleby, P.G. 1986. "Observation of Ag-110m in Chernobyl fallout." Nature 322(6077):313.

Jones, P.M.S. 1987. Constraints. Jones, P.M.S. (ed.), John Wiley and Sons Inc., Chichester, U. $\bar{K}$.

Jones, P.M.S. 1987. Nuclear reactor types. Jones, P.M.S. (ed.), John Wiley and Sons Inc., Chichester, U.K.

Jones, P.M.S. 1987. Safety. Jones, P.M.S. (ed.), John Wiley and Sons Inc., Chichester, U.K.

Jones, R.R. 1987. "Chernobyl and cancer epidemiology." Lancet 1(8537):856.

Jones, R.R. 1986. "Cancer risk assessment in light of Chernobyl." Nature $323(6089): 585-586$.

Jones, R.R.; Southwood, R. (eds.). 1987. "Radiation and health: the biological effects of low-level exposure to ionizing radiation." In International conference on the biological effects of ionizing radiation. CONF-8611250, John Wiley and Sons Inc., Chichester, U.K. 
Joosten, J.K. 1988. "Soviet RBMK-1000 containment system." In Conference on nuclear containment. Walton, D.G. (ed.), CoNF-870411, Cambridge University Press, Cambridge, U.K.

Jopling, M.; John, B.; Davison, J.B.; Townsend, C.D.; Maclennan, R. ; Hughes, M.; Dobson, F.; et al. 1986. "Sheepmeat (caesium levels)." Hansard, House Commons off. Rep. $99(133): 1321-1326$.

Josephson, P.R. 1987. "Roots of the Chernobyl accident." Eur. Arch. 42(4) : 119-128.

Joshi, S.R. 1988. "Fallout of Chernobyl radioactivity in central Ontario, Canada." J. Environ. Radioact. 6(3):203-211.

Joshi, S.R. 1987. "Early Canadian results on the long-range transport of Chernobyl radioactivity." Sci. Total Environ. 63:63.

Jost, D.T.; Gaeggeler, H.W.; Baltensperger, U.; Zinder, B.; Haller, P. 1986. "Chernobyl fallout in size-fractionated aerosol." Nature 324(6092):22-23.

Juzhnicj, K.; Fedina, Sh. 1987. "Sr-90 and Sr-89 concentrations in the environment samples from the territory of Slovenia." In 14. Yugoslav symposium on radiation protection. Yugos lav Radiological Protection Association, Novi Sad, Yugoslavia.

Juznic, K.; Fedina, S. 1987. "Distribution of $\mathrm{Sr}$ in Slovenia, Yugoslavia, after the Chernobyl accident." J. Environ. Radioact. 5(2):159-163.

Julich, GmbH. 1986. Radioaktivittsmessungen nach dem Reaktorunglck Tschernobyl Kernforschungsanlage Julich GmbH, Abteilung Sicherheit und Strahlenschutz, ASS-Bericht Nr. 0438, Zeitraum 1, Mai.

Kaes, H. 1986. "Austria's 0eMV has 'strong interest' in price stability." OPEC Bu11. 17(5):8-10.

Kafka, P. 1987. "Chernobyl accident: A challenge on PSA as a tool for the prediction of event scenarios beyond the design basis and for safety improvements." In 9. SMIRT: international conference on structural mechanics in reactor technology. Wittmann, F.H. (ed.), Balkema, Rotterdam, Netherlands.

Kafka, P.; Koenig, J.; Limmer, W. 1986. Chernobyl - a gross lie dressed up as information. Instructions for exciting public anger. Schneekiuth, Muenchen, Germany, F.R.

Kafka, P.; Maier-Leibnitz, H. 1987. Nuclear energy - yes or no? A debate between two physicists. (2nd Edition). Piper, Muenchen, Germany, F.R.

Kai, M.; Kusama, T.; Sugiura, N.; Niimi, K.; Ban, N.: Fukui, T.; Yoshizawa, Y.: Eguchi, H. 1987. "Estimation of internal exposure of four Japanese travellers to fission products released from the reactor accident at Chernoby1." Radiat. Prot. Dosim. 18(3):175-178. 
Kampe, D. 1987. Radioactivity - a subject of spatial research.

Bundesforschungsanstalt fuer Landeskunde und Raumordnung, Bonn, Germany, F.R.

Kandela, P. 1987. "Physicians for Prevention of Nuclear War prepare to consider applications for clinical research." J. Am. Med. Assoc. 258(5):586.

Kanduch, M.; Krizhman, M.; Kuhar, B.; Jershicj, A. 1987. "Equivalent doses to the population of the SR Slovenia after Chernobyl's reactor accident." In 14. Yugoslar symposium on radiation protection. CONF-8706303, Yugos lav Radiological Protection Association, Novi Sad, Yugoslavia.

Kanel, A. 1986. "Don't make light of Chernobyl." Rev. Polytech. 6-7:641.

Kanel, A. 1986. "Chernobyl: radiation and disinformation." Rev. Polytech. $5: 599-601$.

Kanel, A. 1987. "After Chernobyl, Creys-Malville." Rev. Polytech. 5:498-499.

Kanel, A. 1986. "Chernobyl - hue and cry for the scapegoats." Rev. Polytech. $9: 933$.

Kantelo, M.V.; Winn, H.G. 1986. Summary of Chernobyl fallout monitoring by the Environmental Radiometrics Group. DPST-86-624, Savannah River Lab., Aiken, SC, U.S.A.

Karasev, V.B.; Nikitin, Yu.M.; Novosel'skij, 0.Yu.; Sakovich, E.V. 1982. "Steam separator operation efficiency at power units with the RBMK reactors." At. Energ. p. 70-74.

Karl, H.D.; Scholz, L. 1987. "Economic and ecological consequences of shutting down nuclear plants for power generation." Ifo Schnelldienst 30:13-30.

Karlberg, 0. 1987. "Weathering and migration of Chernobyl fall-out in Sweden." Radiat. Prot. Dosim. 21(1-3):75-78.

Kaspar, D. 1987. "External radiation contamination of plants from Chernoby1." In Forum on impact of radioactive materials on the atmospheric pollutant inventory and on the radioactivity uptake by plants. Ministerium fuer Ernaehrung, Germany, F.R.

Katz, P. 1987. "Dust investigations in air conditioning plants. Quantity and separation of respirable fine-dusts in the plant components." HLH, Heiz. Lueftung, Klim., Haustech. 38(3):139-144.

Kaufmann, M.; Milch, I. 1987. "Fusion research." In AGF congress on Chernobyl and the future of energy supply in the Federal Republic of Germany. Max-Planck-Institut fuer Plasmaphysik, Garching, Germany, F.R. 
Kaul, A. 1987. Chernobyl reactor accident: Environmental impacts, radiation protection measures, radiation hazards assessed from the point of view of radiation hygiene. Gockel, H.P. (ed.), Regensberg und Biermann, Muenster, Germany, F.R.

Kaul, A. 1987. "Chernobyl: Facts, measures, consequences." In 27. annual conference of Vereinigung Deutscher Strahlenschutzaerzte e.V. Schuetz, $\bar{j}$.; Boerner, W.; Messerschmidt, 0. (eds.), CoNf-8605338, Thieme, Stuttgart, Gemany, F.R.

Kaul, A. 1987. "Effective dose and the concept of dose limitation." In 27. annual conference of Vereinigung Deutscher Strahlenschutzaerzte e.V. Schuetz, J.; Boerner, W.; Messerschmidt, 0. (eds.), CoNf-8605338, Thieme, Stuttgart, Germany, F.R.

Kaul, A. 1988. Ionizing radiation. Sources of exposure, doses, risks, legal regulations for radiation protection. MMV Medizin Verl, Germany, F.R.

Kaul, A. 1986. "Chernobyl reactor accident: Quantification and evaluation of the radiation risk." Bundesgesundheitsblatt $29(8): 244-248$.

Kaul, A. 1987. "Radiological consequences of Chernoby1." ATW, Atomwirtsch., Atomtech. 32(11):532-537.

Kaul, A. 1986. "Chernobyl reactor disaster. Facts, actions, consequences." Fleischwirtschaft $66(10): 1486-1488$.

Kaul, A.; Martignoni, K.; Roedler, H.D. 1987. "Radiation risk - concepts, quantification, assessment." Nuklearmediziner 10(5):359-372.

Kauppinen, E.; Hillamo, R.; Jokiniemi, J.: Aaltonen, H.; Sinkko, K. 1986. Radioactivity size distributions of ambient aerosols in Helsinki, Finland during May 1986 after Chernobyl accident. Discussions of accident scenario. Preliminary report. Valtion Teknillinen Tutkimuskeskus, Espoo, Finland.

Kausch, H.G. 1987. "Energy policy prospects." In AGF congress on Chernobyl and the future of energy supply in the Federal Republic of Germany. IAEA, Paris, France.

Kavanagh, J. 1986. "Miners take stock after Chernobyl." Bus. Rev. Wkly. $8(21): 38,42$.

Kawamura, H.; Sakurai, Y.; Shiraishi, K.; Yanagisawa, K. 1988.

"Concentrations of 1-131 in the urine of Japanese adults and children following the Chernobyl nuclear accident." 3 . Environ. Radioact. $6(2): 185-189$.

Kayamori, N.; Murakami, N.; Konishi, T. 1987. "Reactor accident at Chernobyl: jdentification of radionuclides in fallout in Niigata City. "Radioisotopes $36(6): 278-281$. 
Kazimir, 0. 1987. "Radiation background in localities intended for nuclear power plant construction after 1990." Radioaktiv. Zivotn. Prost.

$10(3): 129-137$.

Keil, E.R. 1986. "Institutional planning for radiation emergencies." In International conference on non-military radiation emergencies. DOE/ER/60525-1; CONF, Joint Commission on Accreditation of Hospitals, Chicago, IL, U.S.A.

Kellerer, A.M. 1987. "Revision of quality factors in radiation protection." In 27. annual conference of Vereinigung Deutscher Strahlenschutzaerzte e. $V$. Schuetz, J.; Boerner, W.; Messerschmidt, 0. (eds.), CoNF-8605338, Thieme, Stuttgart, Germany, F.R.

Kemeny, L.G. 1986. "Chernobyl - cause and consequences." J. Inst. Eng. $58(20): 52-54$.

Kemeny, L.G. 1986. "Is Soviet society fit for the nuclear age in the wake of Chernobyl?" Quadrant 30(7-8):97-100.

Kemmer, W. 1987. "Minimization of radiation by quality assurance." In 27. annual conference of Vereinigung Deutscher Strahlenschutzaerzte e.V. Schuetz, J.; Boerner, W.; Messerschmidt, 0. (eds.), CoNF-8605338, Thieme, Stuttgart, Germany, F.R.

Kempe, S.; Nies, H. 1987. "Chernobyl nuclide record from a North Sea sediment trap." Nature 329(6142):828-831.

Kench, R.L. 1988. "Fire safety in atomic power plants." Fire Prev. 207:32-37.

Kennedy, R.T. 1987. "International co-operation following Chernobyl." Newsl. NEA Data Bank 5(1):3-8.

Kennedy, T. 1986. "Measuring radioactivity." Technol. Ireland p. 22-23.

Keppler, E. 1986. "Influence of Chernobyl on the development of electricity supply in Switzerland." Tech. Rundsch. 78(4I):100-105.

Kereiakes, J.G.; Saenger, E.L.; Thomas, S.R. 1986. "Reactor accident at Chernobyl: a nuclear medicine practitioner's perspective." Semin. Nucl. Med. $3: 224-230$.

Kernforschungsanlage Juelich G.m.b.H. 1988. List of scientific and technological reports of the Nuclear Research Center Juelich Jan. $1985=$ March 1988. (2nd Edition). INIS-mf-11802, Kernforschungsanlage Juelich G.m.b.H., Germany, F.R.

Kernforschungszentrum Karlsruhe G.m.b.H. 1986. Information about the latest measuring results obtained for food, September 23,1986 . Internal information. Kernforschungszentrum Karlsruhe G.m.b.H., Germany, F.R. 
Kernforschungszentrum Karlsruhe G.m.b.H. 1986. "Concluding colloquium of the Nuclear Safety Project (PNS). Proceedings." In Colloquium of the Projekt Nukleare Sicherheit (PNS) of the Kernforschungszentrum Karlsruhe G.m.b.H. Kernforschungszentrum Karlsruhe G.m.b.H., Germany, F.R.

Kerr, W. 1987. "Chernobyl - A reminder." In 49. annual American power conference. Illinois Institute of Technology, Chicago, IL, U.S.A.

Keverling Buisman, A.S. 1986. Measurements of persons at ECN, Petten (Netherlands). Document 15-2. Netherlands Energy Research Foundation, Petten, Netherlands.

Keverling Buisman, A.S. 1986. "Internal contamination after the Chernobyl accident." NVS-NieuwS 11(3):18-21.

Keverling Buisman, A.S. 1986. "Measurement of internal contamination." NVS-NieuwS $11(5): 14-15$.

Kibedi, T.; Kiss, A.Z.; Somorjaj, E.; Uray, I. 1986. "Airborne activity and deposition in Debrecen caused by the Chernobyl accidental release." ATOMKI Kozl. 28(4):175-179.

Kiefer, H. 1986. "Consequences of the Chernobyl reactor accident for the dose commitment of the general public." KFK-Nachr. 18(3):133-134.

Kiefer, H. 1986. "Effects of the Chernobyl reactor accident - dose suffered by the population." In Colloquium of the Projekt Nukleare Sicherheit (PNS) of the Kernforschungszentrum Karlsruhe G.m.b.H. Kernforschungszentrum Karlsruhe G.m.b.H., Germany, F.R.

Kiefer, H. 1986. "Population exposure: Effects of the Chernobyl accident." ATW, Atomwirtsch., Atomtech. 31(7):394.

Kiefer, J. 1986. "Biological radiation effects. Extrapolating from high radiation loads to low values." Unwelt 7:534-536.

Kieffer, K.W. 1986. Windscale, Harrisburg, Chernobyl. Georg Michael Pfaff Gedaechtnisstiftung, Kaisers]autern, Germany, F.R.

Kilpi, K. 1987. "Severe accidents and source term research in Finland." In Seminar concerning safety studies on severe accident in light water reactors. EUR-11019, Technical Research Centre of Finland, Helsinki, Fintand.

Kintner, E.E. 1987. "Lessons learned." In Conference on nuclear risks reassessing the principles and practical after Chernobyl. IBC Technical Services Ltd., London, U.K.

Kirchmann, R. 1986. "Implication on future priorities in radiation protection." In Seminar on the Chernobyl accident and its impact. IAEA, Vienna, Austria. 
Kirchner, G.; Noack, C.C. 1988. Core history and nuclide inventory of the Chernobyl core at the time of accident. Silver, E.G. (ed.), Univ. of Bremen, Bremen, Germany, F.R.

Kjelle, P.E. 1986. Fallout in Sweden from Chernobyl. Part II. National Inst. of Radiation Protection, Stockholm, Sweden.

Kjelle, P.E. 1987. Gamma monitoring stations - annual reports 1985-1986. SSI-87-08, National Inst. of Radiation Protection, Stockholm, Sweden.

Kjelle, P.E. 1986. Fallout from Chernobyl. Preliminary report. National Inst. of Radiation Protection, Stockholm, Sweden.

Klenus, V.G.: Kuz'menko, M.I.; Nasvit, 0.I. 1985. Role of algae in water quality regulation in NPP water reservoirs. Egorov, Yu.A. (ed.), Ehnergoatomizdat, Moscow, U.S.S.R.

Klusek, C.S.; Sanderson, C.G.; Rivera, W. 1986. Concentrations of TI, TUCs, and TXCs in milk in the New York metropolitan area following the Chernobyl reactor accident. Volchok, H.L.; Chieco, N. (eds.), USDOE Environmental Measurements Lab., New York, NY, U.S.A.

Knabe, B. 1986. Reactor accident at the Chernobyl nuclear power station. Bundesinstitut fuer Ostwissenschaftliche und Internationale Studien, Koeln, Germany, F.R.

Knox, J.B.: MacCracken, M.C.; Dickerson, M.H.; Gresho, P.M.; Luther, F.M. 1986. Program report for FY 1984 and 1985 Atmospheric and Geophysical

Sciences Division of the Physics Department. Lawrence Livermore National Lab., Livermore, CA, U.S.A.

Knuth, R.H.; Sanderson, C.G. 1986. Particle size distribution of Chernobyl related aerosols in New York City. Volchok, H.L.; Chieco, N. (eds.), USDOE Environmental Measurements Lab., New York, NY, U.S.A.

Koch, E.R.; Vahrenholt, F. 1986. Not prepared for this emergency. Disaster control in case of nuclear accidents. Kiepenheuer und Witsch, Koein, Germany, F.R.

Koch, G. 1986. "Radioactivity and radiation load. The Chernobyl reactor accident." Allg. Forst Z. 41(28):714-715.

Kocks, K.; Kukuck, H.A. 1987. "Young people and their attitude towards energy policy. An IZE study of 1986/1987." Energiewirtsch. Tagesfragen $37(9): 740-744$.

Koeberlein, K. 1987. "Safety analyses in the light of TMI and Chernobyl." ATW, Atomwirtsch., Atomtech. 32(5):237-243.

Koeberlein, K. 1987. "Safety in nuclear power plants." Zentralbl. Arbeitsmed., Arbeitsschutz, Prophyl. Ergon. 37(5):134-142. 
Koenig, L.A.; Fessler, H. 1987. "Exposure of trees to radiation due to the Chernobyl accident." In Forum on impact of radioactive materials on the atmospheric pollutant inventory and on the radioactivity uptake by plants. Kernforschungszentrum Karlsruhe G.m.b.H., Germany, F.R.

Koenig, L.A.; Fessler, H.; Hempelmann, S.; Milbich-Muenzer, F. 1987. Radioactivity in forests and single trees caused by the Chernobyl reactor accident. Kernforschungszentrum Karlsruhe G.m.b.H., Germany, F.R.

Koenig, L.A.; Schuettelkopf, H.; Erat, S.; Fessler, H.; Hempelmann, S.; Maurer, K.: Pimpl, M. 1986. Reactor accident of Chernobyl. Measurements performed in the Karlsruhe Nuclear Research Center. Kernforschungszentrum Karlsruhe G.m.b.H., Germany, F.R.

Koester, H.W.; Mattern, F.C.M.; Pennders, R.M.J. 1987. Radioactive contamination of the Dutch soil in consequence of the nuclear reactor accident at Chernobyl. Document 6. Rijksinstituut voor Volksgezondheid en Milieuhygiene, Bilthoven, Netherlands.

Kohl, M. 1986. "Chernobyl - Waterloo of the nuclear energy." Schweiz. Ver. Atomenerg., Bul1. 28(15):27-36.

Kohn, M. 1988. "Power engineering specialist between technology and society." Elektrotech. Inf.tech. 105(5):212-216.

Kolb, H. 1987. "Spread calculations on the Chernobyl accident." In Annual meeting on nuclear technology. CONF-870602, Deutsches Atomforum e.v., Bonn, Germany, F.R.

Kolb, H.; Mahringer, G.; Seibert, P.; Sobitschka, W.; Steinhauser, P.; Zwatz-Meise, V. 1986. Preliminary meteorological analysis of the radioactive contamination in Austria during and after the nuclear accident at Chernobyl. Zentralanstalt fuer Meteorologie und Geodynamik, Vienna, Austria.

Kolb, W. 1986. Investigation of the amount, distribution, and contents of atmospheric precipitations. Rheinischer Landwirtschafts-Verl., Bonn, Germany, F.R.

Kolb. W. 1988. Radionuclide concentration in ground-level air from 1986 to 1987 in North Germany and North Norway. PTB-Ra-21, Physikalisch-Technische Bundesanstalt, Braunschweig, Germany, F.R.

Kolb, W. 1986. Radionuclide concentrations in ground-level air from 1984 to mid 1986 in North Germany and North Norway; influence of the Chernobyl accident. Physikalisch-Technische Bundesanstalt, Braunschweig, Germany, F.R.

Kolb, W.; Lauterbach, U.; Pessara, W. 1986. "Impacts of the Chernobyl reactor accident on the environmental activity in the eastern part of Lower Saxony." PTB-Mitt. 96 (4) :252-255. 
Kollas, J.G. 1987. "The Radiological Impact of the Chernobyl Accident in Greece" In Workshop on the Radiological Consequences of Chernobyl, Commission of European Communities. NRCPS "Democritos", Attiki, Greece.

Kollmer, B.D.; Kriegel, W.E.; Henrichs, K. 1987. "Radioactive iodine and cesium in Bavarian citizens after the nuclear reactor accident in Chernobyl." In 21. annual conference on trace substances in environmental health. Hemphil1, 0.0. (ed.), CoNF-8705217, University of Missouri, Columbia, M0, U.S.A.

Konstantinov, L.V.; Char, N.L.; Bennett, L.L. 1987. "Nuclear power for the developing world." In 11. annual symposium of the Uranium Institute. Uranium Institute, London, U.K.

Konstanz Univ. 1987. Annual report 1986 for the field 'nuclear solid state physics' of the University of Konstanz. Konstanz Univ., Konstanz, Germany, F.R.

Konviz, V.S.; Golubkov, L.V. 1984. "Chernobylsk-3 NPP." Energ. Stroit. $1: 19-23$.

Kops, J.A.M.M. 1986. "Gamma spectrometry of fallout deposits in Europe after the Chernobyl accident." NVS-Nieuws $11(3): 16-17$.

Kops, J.A.M.M. 1986. "Radiation burden in the Netherlands after the reactor accident at Chernobyl." NVS-Nieuws 11(3):9-15.

Kops, J.A.M.M.; Scholten, L.C. 1987. "Measurements of the radioactivity of air after the Chernobyl accident." NVS-Nieuws 12(1):19-22.

Korchagina, V.: Khrustov, V. 1987. "Ignalina - a Soviet perspective." Nucl. Eng. Int. 32(395):23.

Korhonen, R. 1988. "Validation of the biospheric transfer models by employing Chernobyl data." 르 2:6-9.

Kossel, F. 1987. "DIN standards and the new ordinances." In 27. annual conference of Vereinigung Deutscher Strahlenschutzaerzte e.V. Schuetz, J.: Boerner, W.; Messerschmidt, 0. (eds.), CoNF-8605338, Thieme, Stuttgart, Germany, F.R.

Kotler, L.H. 1987. "Whole body measurements of subjects who have ingested radioactive materials from the accident at Chernobyl." Radiat. Prot. Aust. $5(1): 23-26$.

Kotthoff, K.; Erven, U. 1987. "State of the analyses of the Chernobyl accident." ATW, Atomwirtsch., Atomtech. 32(1):32-37.

Kotthoff, K.: Erven, U. 1987. "Accident in Chernobyl power station. Scenario and significance." GIT Fachz. Lab. 31(11):1072-1078. 
Kouts, H. 1986. Brookhaven lecture series No. 227: The Chernobyl accident. Brookhaven Nationa] Lab., Upton, NY, U.S.A.

Kouyama, H.; Tatsunami, S.; Watabe, S.; Hara, M.; Hara, K. 1988. "Artificial radioactivity in the vicinity of St. Marianna University School of Medicine after the Chernobyl reactor accident." Sei Marianna Ika Daigaku Zasshi $16(1): 115-126$.

Kovan, R. 1987. "New containments for old." Atom 369:13-15.

Kraemer, H. 1987. "One year after Chernobyl: Conclusions from the viewpoint of the electricity economy." Elektrizitaetswirtschaft 86(16/17):744-748.

Kraemer, H. 1987. "Nuclear power concept of the electricity utilities." ATW, Atomwirtsch., Atomtech. 32(8/9):403-406.

Kraemer, J. 1988. "Role of nuclear energy for the energy policy of the GDR." Kernenergie $31(5): 194-196$.

Krafft, P. 1987. "Electricity and nuclear power." Electro-Rev. 79(20):15-18.

Krafft, P. 1987. "Electricity and nuclear energy." Schweiz. Ver. Atomenerg., Bul1. 29(11):19-22.

Kraftwerk Union A.G. 1987. Facts and arguments for the topical discussion about the peaceful uses of nuclear energy. (2nd Edition). Kraftwerk Union A.G., Ruhr, Germany, F.R.

Krajcar Bronicj, I.; Obelicj, B.; Srdoch, D.; Hernaus, E. 1987. "Tritium activity peak in rainwater and water supply in northwest Croatia after the accident at the Chernoby1." In 14. Yugoslav symposium on radiation protection. CONF-8706303, Yugos Tav Radiological Protection Association, Novi Sad, Yugos lavia.

Kral, W.A. 1987. "To warn is better than to alarm." Technica 36(13):25-30.

Krause, C.; Zucker, A.; Corril1, L. (eds.). 1987. Oak Ridge National Laboratory review: Volume 20, No. 2, 1987. Oak Ridge National Lab., Oak Ridge, TN, U.S.A.

Kreiner, H.J. 1988. "Equipment for nationwide radiation measurement." Nucl. Eur. 8(3-4):23-24.

Kress, T.S.; Jankowski, M.W.; Joosten, J.K.; Powers, D.A. 1987. "Chernobyl accident sequence." Nucl. Saf. 28(1):1-9.

Kresten, P. 1986. Radioactive fallout caused by the reactor accident at Chernobyl: Observations April-May 1986. Sveriges Geologiska Undersoekning, Uppsala, Sweden. 
Kretzschmar, H. 1987. Chernobyl $\rightarrow$ man. A window booklet on radioactivity. (2nd Edition). Energum - Energie-und Unweltinstitut e.V., Muenster, Germany, F.R.

Krey, P.H. 1986. International data exchange and cooperative research. Volchok, H.L.; Chieco, N. (eds.), USDOE Environmental Measurements Lab., New York, NY, U.S.A.

Krey, P.H.: Klusek, C.S.; Sanderson, C.; Miller, K.; Helfer, I. 1986. Radiochemical characterization of Chernobyl fallout in Europe. Volchok, H.L.: Chieco, N. (eds.), USDOE Environmental Measurements Lab., New York, NY, U.S.A.

Krieg, R. 1988. How safe are nuclear reactors? Verl. Bonn Aktuell, Stuttgart, Germany, F.R.

Kristoferson, L.; Kjellstroen, B.: Svenningsson, P.J. 1986. Risks of disaster in the energy system. After Chernobyl. Statens Energiverk, Stockhoim, Sweden.

Krivan, V.; Egger, K.P.; Hausbeck, R.; Schmid, W. 1986. "Contamination of the air and other environmental samples of the Ulm region by radjoactive fission products after the accident of the Chernobyl reactor." Fresenius' $Z$. Anal. Chem. 325(7):597-602.

Krizhman, M.; Kanduch, M. 1987. "Deposition of radioactive contamination on grass after the Chernobyl accident." In 14. Yugoslav symposium on radiation protection. CONF-8706303, Yugos lav Radiological Protection Association, Novi Sad, Yugostavia.

Kroeger, H. 1987. "Chernobyl - course of the accident and plant technology." In AGF congress on Chernobyl and the future of energy supply in the Federal Republic of Germany. Kernforschungsanlage Juelich G.m.b.H., Germany, F.R.

Kroeger, H. 1986. Nuclear power plants near consumers from a safety-engineering point of view. An analysis including modern probabilistic approaches and a suggestion for appropriate safety requirements. Kernforschungsanlage Juelich G.m.b.H., Germany, F.R.

Kroeger, W.; Garribba, S.; Sarlos, G. 1987. "Non-catastrophic release requirements for the next generation of nuclear reactors." In Seminar on small and medium-sized nuclear reactors: safety and licensing issues. EPFL, Lausanne, Switzerland.

Kroeger, H.; Nickel, H.; Schulten, R. 1986. "Safety characteristics of modern high-temperature reactors." In SVA information meeting on safety of nuclear power plants in the light of TMI and Chernobyl. Schweizerische Vereinigung fuer Atomenergie, Bern, Switzerland. 
Krushelnitskiy, V.K. 1987. "Rules and objectives of the USSR State Cormittee on Supervision of Nuclear Power Safety in preventing nuclear power plant accidents." In Conference on nuclear risks - reassessing the principles and practical after Chernobyl. IBC Technical Services Ltd., London, U.K.

Kuehne, G. 1986. "Liability for transfrontier damage from nuclear reactor accidents." Neue Jurist. Hochenschr. 39(35):2139-2146.

Kuhbier, P. 1986. "About the almost certain occurrence of an almost impossible event - or why there is little chance to escape a highly improbable nuclear accident?" Leviathan 4:606-614.

Kuile, C.R. ter; Van Dijk, E. 1986. Nuclear power installations in Europe. Document 20. Rijksinstituut yoor Volksgezondheid en Milieuhygiene, Bilthoven, Netherlands.

Kullander, S.; Larsson, B. 1986. Chernobyl in perspective. Uppsala Univ., Uppsala, Sweden.

Kunsch, B.: Humer, H. 1987. ISCHER: a data bank for samoles which were measured in Austria following the Chernobyl accident (preliminary version). 0EFZS-A-1000, Desterreichisches Forschungszentrum Seibersdorf G.m.b.H., Vienna, Austria.

Kuramoto, A. 1987. "Medical actions following the accident at Chernobyl nuclear power plant." Genshiryoku Kogyo 33(9):51-60.

Kusakabe, M.; Ku, T.h.; Harada, K.; Taguchi, K.; Tsunogai, S. 1988. "Chernobyl radioactivity found in mid-water sediment interceptors in the $N$. Pacific and Bering Sea." Geophys. Res. Lett. 15(1):44-47.

Kutschera, H.; Fink, D.; Paul, M.; Hollos, G.; Kaufman, A. 1986. "Measurement of the SZI/TI ratio in Chernobyl fallout." In Adriatico research conference on environmental physics: the physics of aerosots. Technische Univ. Muenchen, Garching, Germany, F.R.

Kuzmin, I. 1987. "Presentation." In Conference on nuclear risks - reassessing the principles and practical after Chernobyl. IBC Technical Services Ltd., London, U.K.

Kyrki-Rajamaeki, R.: Rajamaeki, M. 1987. "Dynamic analys is of the Chernobyl accident with the one-dimensional program TRAB." Trans. Am. Nuc1. SoC. $54: 222-223$.

L'Homme, A. 1987. "Accident of Chernobylsk: emission and dispersion of radioactive products." In SFEN meeting on Chernobyl accident: safety and environmental aspects. CEA Centre d'Etudes Nucleaires de Fontenay-aux-Roses, France. 
LIH. 1986. The Radioactive Contamination Levels in China and Health Evaluation Following the Radioactive Release from the Soviet Chernobyl Nuclear Power Plant Accident Laboratory of Industrial Hygiene, Ministry of Public Health, Beijing.

LaBrecque, J.J.; Schelenz, R.; Perkins, R.W. 1987. "Determination of radionuclides in grass ecosystem samples. Report of the consultants' meeting, Vienna, 23-25 September 1986." In Consultants' meeting on the determination of radionuclides in grass ecosystem samples. IAEA, Seibersdorf, Austria.

Laaksonen, J. 1986. "Accident at the Chernobyl Nuclear Power Plant." In SRE symposium. Finnish Centre for Radiation and nuclear power plant, Helsinki, Finland.

Labbe, B. 1987. "Ranking French nuclear industry on international market." Nucl. Eur. $7(10): 19-20$.

Lah1, U. 1986. "Chernobyl viewed from a municipal authority perspective." In Meeting on after the Chernobyl accident: how safe is our food?. CONF-8606412, Stiftung Verbraucherinstitut, Berlin, Germany, F.R.

Lajchter, Y.: German, U.; Levin, S.; Sberlo, E.; Knimah, N.; Najm, E. 1987. "Radiation fallout and assessment of radiation dose to the population of southern Israel following the Chernobyl accident." In Israel Health Physics Socjety annual meeting. Israel Atomic Energy Commission, Beersheba, Israel.

Laitano, R.F. 1987. "Chernobyl radioactivity measurements: Reliability, recommendations." In Conference AIRP sull'incidente di Chernobyl. Ass. It. Protezione Contro le Radiazioní, Bologna, Italy.

Lambert, B.E. 1987. "Effects of Chernobyl." In International conference on the biological effects of ionizing radiation. Jones, R.R.; Southwood, R. (eds.), CONF-8611250, John Wiley and Sons Inc., Chichester, U.K.

Lancsarics, Gy.; Feher, I.; Sagi, L.; Palfalvi, J. 1988. "Transuranium elements in the hot particles emitted during the Chernobyl accident." Radiat. Prot. Dosim. 22(2):111-113.

Landesamt fuer Wasser und Abfall Nordrhein-Westfalen. 1986. Chernobyl reactor accident and its effects with regard to surface waters and the drinking water supply in the Land North-Rhine Westphalia. Landesamt fuer Wasser und Abfall Nordrhein-Westfalen, Duesseldorf, Germany, F.R.

Lane, D. 1987. "ENEL counts the cost of rejecting nuclear power." Energy Econ, 68:v.

Lang, D. 1987. "After Chernobyl." Aust. Phys. 24(3):63-66. 
Lange, R.; Dickerson, M.H.: Gudiksen, P.H. 1987. "Dose estimates from the Chernobyl accident." In Joint meeting of the American Nuclear Society and the Atomic Industrial Forum. Lawrence Livermore National Lab., Livermore, CA, U.S.A.

Larsen, R.J.; Sanderson, C.G.; Rivera, W.; Zamichieli, M. 1986. Characterization of radionuclides in North American and Hawai ian surface air and deposition following the Chernobyl accident. Volchok, H.L.; Chieco, N. (eds.), USDOE Environmental Measurements Lab., New York, NY, U.S.A.

Larsson, L.G. 1986. "Radiation and cancer incidence - some reflections on the Swedish cancer panorama." In Conference on radiation and health hazards: Chernobyl in perspective. Regionsjukhuset, Umeaa, Sweden.

Laschka, D.; Hermann, H.; Huebel, K.; Luensmann, W. 1987. "Radiological effects of the Chernobyl reactor accident on the lakes of Southern Bavaria." GWF, Gas-Wasserfach 128(2):128-135.

Latarjet, R. 1986. "About the nuclear accident of Chernobyl." Comp. Rend. Acad. Sci., Ser. 2: 303(2):105-110.

Lauterbach, U. 1988. Activity measurements with portable contamination measuring instruments - comparison measurements with calibrated surface sources. PTB-Ra-20, Physikatisch-Technische Bundesanstalt, Braunschweig, Germany, F.R.

Lauterbach, U.; Kolb, $W$. 1986. "Impacts of the Chernobyl reactor accident on the radiation exposure of the population in the town of Braunschweig." PTB-Mitt. 96(4):257-258.

Laylavoix, F.; Madelmont, C. and Parmentier, N. 1987. "Preliminary Dose Assessment after Chernobyl Accident" In Workshop on the Radiological Consequences of Chernoby 1 , Commission of European Communities. Institut de Protection et de Surete Nucleaire, Fontenay-aux-Roses.

Lazzarini, E. 1986. "On the news string: Irradiation diseases and risks." Elettrotecnica $73(10): 919-925$.

Leao, J.L.B. 1985. Chernobyl. Associacao Brasileira de Fisicos en Medicina, Rio de Janeiro, Brazil.

Lear, R.D.; 0'Neal, E.M.; Crawford, R.B.; De Vore, L.; Hendry, D.P. ; Kirvel, R.D. 1987. Energy and Technology Review, August 1987. Lawrence Livermore National Lab., Livermore, CA, U.S.A.

Leatherhead, T.M. 1987. Radioactivity in the North Sea. North Sea Forum, London, U.K.

Lechner, W.: Huter, 0.; Daxenbichler, G.; Marth, C. 1986. "Radioactivity in breast milk after Chernobyl." Lancet $1(8493): 1326$. 
Leclercq, J. 1987. "French NPPs: the challenge of excellence." Nucl. Eur. $7(10): 14-15$.

Lee, B. Jr. 1987. "Chernobyl one year later." In 49. annual American power conference. Illinois Institute of Technology, Chicago, IL, U.S.A.

Leenhouts, H.P.; Koester, H.W.; Stoutjesdijk, J.F. 1986. Estimation of the radiation dose in the Netherlands caused by the Chernobyl accident. Document 17. Rijksinstituut voor Volksgezondheid en Milieuhygiene, Bilthoven, Netherlands.

Legassov, V. 1987. "Nuclear energy in USSR after Chernobyl." Rev. Polytech. $6-7: 661,663,665$.

Legassow, W. 1988. "I cannot be silent." Schweiz. Ver. Atomenerg., Bull. $30(12): 27-33$.

Lehmann, W.M. 1986. "'Chernoby1' outside German border posts. Diversely motivated decisions." At. Strom 32(5):168-171.

Lehmann, H.M. 1986. "Large-Scale Research experts voice opinion on Chernobyl. Lectures of the AGF on the future of the energy supply." At. Strom $32(5): 155-158$.

Lehmler, W.; Schmitz-Veltin, G. 1987. One year after Chernobyl. Physical and social aspects. Exhibition in the information centre of the Konstanz University Library, April 22 to May 21, 1987. Catalogue and bibliography. INIS-mf-11818, Konstanz Univ., Germany, F.R.

Leifer, R.; Helfer, I.; Miller, K.; Silvestri, S. 1986. Concentrations of gaseous TI in New York City air following the Chernobyl accident. Volchok, H.L.; Chieco, N. (eds.), USDOE Environmental Measurements Lab., New York, NY, U.S.A.

Lejeune, P.; Gillard, J.; Declercq, H.; Avaux, J.L.; Binet, J.; Flemal, J.M. 1986. "Chernobyl. Radioactivity measurements in Belgium and abroad." Rev. Energ. Primaire 20(1-2):47-68.

Lenzer, C. 1986. "Bad joke of history. Chernobyl must not lead to a freeze of German nuclear power plants." Bonner Energ.-Rep. 7(10):21-24.

Lepel, E.A.; Hensley, W.K.; Boatman, J.F.; Busness, K.M.; Davis, W.E.; Robertson, D.E. 1987. "In-situ gamma-ray measurements in the Chernobyi plume." In International conference on methods and applications of radioanalytical chemistry. Pacific Northwest Lab., Richland, WA, U.S.A.

Leppin, W. 1987. "Prenatal radiation exposure. Conclusions in the light of radiology." In 27. annual conference of Vereinigung Deutscher

Strahlenschutzaerzte e.V. Schuetz, J.; Boerner, W.; Messerschmidt, 0. (eds.), CONF-8605338, Thieme, Stuttgart, Germany, F.R. 
Lester, T.F. 1987. "Effect of the nuclear accident at Chernobyl in the USSR on the export of milk products from the United Kingdom." J. Soc. Dairy Technol. 40(3):59-60.

Lewis, H.W. 1986. "Accident at the Chernobyl nuclear power plant and its consequences." Environment 28(9):25-27.

Libmann, J. 1987. Pressurized water reactor safety approach and analysis. From conception to experience feedback. CEA Centre d'Etudes Nucleaíres de Fontenay-aux-Roses, France.

Li1jenzin, J.0.; Skaalberg, M.; Persson, G.; Ingemansson, T.; Aronsson, P.0. 1988. "Analysis of the fallout in Sweden from Chernobyl." Radiochim. Acta $43(1): 1-25$.

Lindah1, I.; Haabrekke, H. 1986. Determination of radioactive fallout after the Chernobyl accident. Norges Geologiske Undersoekelse, 0s To, Norway.

Lindell, B. 1986. "Overview of radiation emergencies: international perspective." In International conference on non-military radiation emergencies. D0E/ER/60525-1. Swedish National Institute of Radiation Protection, Stockholm, Sweden.

Linde11, B. 1986. "Radiation risks and the Chernobyl accident." Vaar Foeda Suppl. 3:137-200.

Lindell, 8. 1987. "Radiation and health." Bull. World Health Organ. $65(2): 139-148$.

Lindner, G.; Deicher, M.; Hofsaess, H.; Jahn, S.; Petermann, D.; Pfeiffer, W.; Wahi, U. 1987. "Radioact ive contamination in the Lake of Constance area after the Chernobyl reactor accident." In Annual meeting on nuclear technology. Deutsches Atomforum e.V., Bonn, Germany, F.R.

Lingjaerde, R.0. 1987. Nuclear power - status and development 1986/1987. Institute for Energy Technology, Kjeller, Norway.

Linnemann, R.E. 1987. "Soviet medical response to the Chernobyl nuclear accident." J. Am. Med. Assoc. 258(5):637-643.

Linsley, G.S. 1986. "Environmental Aspect of the Chernobyl Accident" In Seminar at Lawrence Livermore National Laboratory. Institute for Energy Technology, Kjeller, Norway.

Linssen, G. 1987. "Welding in nuclear engineering - after Chernobyl." Schweissen Schneiden 39(2):63-66.

Liritzis, Y. 1987. "Chernobyl fallout in Greece and its effects on the dating of archaeological materials." Nucl. Instrum. Methods Phys. Res. $260(2 / 3): 534-537$. 
Lischka, K.D.; Wernicke, J. 1986. "Food monitoring for radioactivity concentrations after the Chernobyl accident: Consequences for the citizen." In Meeting on after the Chernobyl accident: how safe is our food?. CoNF-8606412, Stiftung Verbraucherinstitut, Berlin, Germany, F.R.

Livingston, H.D.; Clarke, W.R.; Honjo, S.; Izdar, E.; Konuk, T.; Degens, E.; Ittekkot, $V .1986$. Chernobyl fallout studies in the Black Sea and other ocean areas. Woods Hole Oceanographic Institution, MA, U.S.A.

Locke, D.H.: Caley, J.R. 1987. Case for the UK nuclear power industry and the implications of its closure. ND-R-1466(R), UKAEA Northern Research Labs., Risley, U.K.

Loenner, G.; Nilsson, S.; Nordvall, H.0. 1986. Analysis of forestry region when changing energy prices. After Chernobyl. Statens Energiverk, Stockholm, Sweden.

Loester, W. 1986. Dosimetry concepts and their use in radiation exposure in humans. Geselischaft fuer Strahlen-und Umweltforschung m.b.H. Muenchen, Neuherberg, Germany, F.R.

Loewenstein, W.B.; Thomas, G.R. 1987. "Nuclear safety--forward on technology and backward on perception." In 14. water reactor safety information meeting. Weiss, A.J., ed. Electric Power Research Inst., Palo ATto, CA, U.S.A.

Loizzo, P. 1987. "Neutronics of the Chernobyl accident." Energ. Nucl. $4(3): 31-40$.

Loizzo, P. 1987. "Chernobyl experiment." Energ. Innov.: Notiz. ENEA $33(9): 24-26$.

London Nuclear Information Unit (UK). 1987. "Report of the South East region nuclear free zone seminar on nuclear power, organised by the London Nuclear 1nformation Unit at Camden Town Hall, 17 July 1986." In South East region nuclear free zone seminar. London Nuclear Information Unit, London, U.K.

Longworth, J.P.: Tobias, A. 1986. Use of activity measurements in the plume from Chernobyl to deduce fuel state before, during and after the accident. Central Electricity Generating Board, Berkeley, U.K.

Loprieno, N. 1986. "Radiation knows no frontiers. Chernobyl's challenge to science and government." Eur. Environ. Rev. 1(1):2-9.

Lote, K.; Klepp, 0.; Reitan, J.B. 1986. "Radioactive fallout from reactor accidents and nuclear weapons." Tidsskr. Nor. Laegeforen. 106(23) : 1836-1840.

Lowe, V.P.W.; Horrill, A.D. 1988. "Ecological half-life of caesium in roe deer (Capreolus capreolus)." Environ. Pollut. 54(2):81-87.

Lukes, R. 1986. "Legal issues related to the discontinuation of peaceful nuclear energy use." Betr.-Berat. 20:1305-1310. 
Lukes, R. 1987. "Legal aspects of a nuclear power plant." Energiewirtsch. Tagesfragen $37(4): 361-365$.

Lukonin, N.F. 1987. "Nuclear technology development program in the USSR." Gensan Nenji Tajkai Hobunshu 20:I/2/1-I/2/8.

Lukonin, N.F. 1988. "Nuclear power after Chernobyl: Current problems and performance prospects of nuclear power plants." In International conference on nuclear power performance and safety. CONF-8709263. IAEA, Vienna, Austría.

Lukonin, N.F. 1987. "Nuclear power in the USSR. Current problems and the prospects of NPP performances." At. Energ. 63(5):291-294.

Lushbaugh, C.C.; Fry, S.A.; Ricks, R.C. 1987. "Medical and radiobiological basis of radiation accident management." Br. J. Radiol. 60(720):1159-1163.

Lushbaugh, C.C.; Ricks, R.C.; Fry, S.A. 1986. "US perspective on Chernobyl." In International conference on non-military radiation emergencies. DOE-ER60525-1, Radiation Emergency Assistance Center, Oak Rídge, TN, U.S.A. Lutz, R.J. Jr.; Hochreiter, L.E.; Mcadoo, J.D.: Liparulo, N.J. 1987. "Chernobyl: One year later." In 49. annual American power conference. Illinois Institute of Technology, Chicago, IL, U.S.A.

Lymberis, C.; Makrigiorgos, G.; Polizois, E.; Mortzos, G.; Bacas, A.; Sbonias, E.: Fountos, A. 1988. "Radiocesium levels in human muscle samples in Greece one year after the Chernobyl accident." Appl. Radiat. Isot. $39(2): 175-176$.

Lysyuk, R.I.; Kareva, A.P. 1984. "Concreting organization during Chernobylsk NPP construction." Energ. Stroit. 11:8-9.

M. Baggenstos. 1986. "Radiological Situation in Switzerland After Tschernobyl" In Meeting at Brookhaven National Laboratory. Swiss Nuclear Safety Inspectorate.

MacInnes, D.A.; Gittus, J.H. 1988. "Pellet-clad interaction during transients: the evolution of fission gas from overheated U02." In International approach to nuclear safety seminar. Ballard, G.M. (ed.), CONF-8806174, Elsevier Applied Science, London, U.K.

MacKenzie, D. 1986. "Rad-dosed reindeer." New Sci. 112(1539):37-40.

Macdonald, H.F.; Apsimon, H.M.; Wilson, J.J.N. 1986. Initial assessment of the Chernobyl -4 reactor accident release source. Central Electricity Generating Board, Berkeley, U.K.

Macdonald, H.F.; Harte, G.A.; Corbett, J.0. 1987. "Developments in emergency monitoring arrangements at Central Electricity Generating Board nuclear power stations since the Three Mile Island accident." Nucl. Energy 26(1):31-40.

Machalek, A. 1986. Living with radioactivity. An adviser for the future. Verlag ORAC, Vienna, Austria. 
Mackay, L. 1988. Lines of longitude: people's detente, North and South. Mackay, L.; Thompson, M. (eds.), Pluto Press, London, U.K.

Mackay, L.; Thompson, M. 1988. Introduction: Chernobyl and beyond. Mackay, L.; Thompson, M. (eds.), Pluto Press, London, U.K.

Mackay, L.; Thompson, M. (eds.). 1988. Something in the wind. Politics after Chernobyl. Pluto Press, London, U.K.

Mackerron, G. 1988. Alternative energy. Mackay, L.; Thompson, M. (eds.), Pluto Press, London, U.K.

Maier-Leibnitz, H. 1987. Chernobyl and its consequences. Between emotion and communication. Arbeitgeberverband der Metallindustrie im Regierungsbezirk Koeln e.V., Koeln, Germany, F.R.

Maier-Leibnitz, H. 1986. "First consequences to be drawn from the Chernobyl reactor accident." Naturwiss. Rundsch. 39(7):302-306.

Makukhin, A.N. 1986. "Development of power engineering during 1985, targets for 1986 and the 12th five-year plan." Teploenergetika 2:2-5.

Malatova, I.; Bucina, I.; Koublova, I.; Drabova, D.; Thomas, J. 1988. "Internal irradiation of Czechoslovak population after the Chernobyl accident II. (poster)." In 20. international symposium on radiation protection physics. INIS-mf-11311, Institut Hygieny a Epidemiologie, Prague, Czechostovakia.

Malinauskas, A.P. 1987. "The Chernobyl accident: Causes and consequences." In ANS topical conference on population exposure from nuclear fuel cycle. Oak Ridge National Lab., Oak Ridge, TN, U.S.A.

Malinauskas, A.P.; Buchanan, J.R.: Lorenz, R.A.; Yamashita, T. 1986. "Chernobyl reactor accident." In American Society of Mechanical Engineers winter meeting. Oak Ridge National Lab., Oak Ridge, TN, U.S.A.

Malinauskas, A.P.; Buchanan, J.R.; Lorenz, R.A.; Yamashita, T. 1987. "Calamity at Chernobyl." Mech. Eng. 109(2):50-53.

Mamet, V.A. 1986. "On the application of neutral-oxygen regime at a NPP." Teploenergetika $3: 64$.

Maqua, M.: Bonka, H.; Horn, H.-G. 1987. "Deposition velocity and washout coefficient of radionuclides bound to aerosol particles and elemental radioiodine." Radiat. Prot. Dosim. 21(1-3):43-49.

Marcus, F.; Bistroem, J.; Toenne, T.; WikdahT, C.E. 1987. "Energy scene in the Nordic countries." Nucl. Eur. 7(11-12):8-10.

Mark, H.; Carver, L. 1987. "Challenger and Chernobyl: lessons and reflections." Interdiscip. Sci.Rev. 12(3):241-252. 
Markov, E.P.; Yavorskij, A.N.; Dyadyakin, B.V.; Aleksandrov, I.P. 1984. "Chernobylsk-3 NPP pressure-suppression system performance testing." Energ. Stroit. 1:61-62.

Marples, D.R. 1987. Chernobyl and nuclear power in the USSR. St. Martins Press, New York, NY, U.S.A.

Marsha11, V.C. 1988. "Perspective view of industrial disasters: (was Chernobyl the worst?)." Atom 376:2-7.

Marshal1, W. 1987. "Banquet address." In 11. annual symposium of the Uranium Institute. CONF-860915, Uranium Institute, London, U.K.

Marsha11, W. 1987. Comments on the Chernobyl accident. Geary, N. (ed.), Sterling Publications Ltd., London, U.K.

Marshall, W. 1986. "National report: United Kingdom. Chernobyl - the aftermath. What can the industry learn from the accident?" IAEA Bull. $28(3): 36-38$.

Marsha]l, W. 1986. "Chernobyl and its repercussions. Nuclear power: energy of today and tomorrow." Nucl. Eng. 27(4):128-131.

Marshal1, W. 1986. "Chernobyl syndrome." Link-Up p. 34-36.

Marshall, W. 1986. "Hazards of civil nuclear power in the light of the Chernobyl disaster." Sci. Parliam. 143(185):223-225.

Marth, W. 1986. "Safety of fast breeders as illustrated by the example of the Kalkar nuclear power plant." In SVA information meeting on safety of nuclear power plants in the light of TMI and Chernobyl. Schweizerische Vereinigung fuer Atomenergie, Bern, Switzerland.

Martin, C.J.; Heaton, B.; Robb, J.D. 1988. "Studies of I-131, C5-137 and Ru-103 in mi $x_{k}$, meat and vegetables in North East Scotland following the Chernobyl accident." J. Environ. Radioact. 6(3):247-259.

Martin, J. 1986. "Radioactivity and radiation exposure of the population after the Chernobyl accident." Siemens-z. 60(4):9-11.

Martin, J. 1987. "Late effects of Chernobyl: Position of Prof. Gale concerning nuclear energy. Perspectives of radiation exposure after Chernoby 1." ATW, Atomwirtsch., Atomtech. 32(5):259.

Martin, J.B. 1987. "Emergency preparedness lessons from Chernobyl." In 21. mid-year meeting of the Health Physics Society: power reactor health physics. Pacific Northwest Lab., Richland, WA, U.S.A.

Martin, J.M.; Thomas, A.J. 1988. "Anomalous concentrations of atmospheric plutonium-238 over Paris." J. Environ. Radioact. 7(1):1-16. 
Martin, S.; Arnott, D. 1988. "Chernobyl explosion bombshe11." SCRAM: Anti-Nucl. Safe Energy J. 64:12-13.

Martinchich, R.; Pucelj, B. 1987. "Protective measures in SR Slovenia during the Chernobyl accident." In 14. Yugoslav symposium on radiation protection. CONF-8706303, Yugoslav Radiological Protection Association, Novi Sad, Yugoslavia.

Mascanzoni, D. 1986. Aftermath of Chernobyl in Sweden: Levels of C5-137 in foodstuffs. Swedish Univ. of Agricultural Sciences, Uppsala, Sweden.

Maslov, V.P.; Myasnikov, V.P.; Danilov, V.G. 1987. Computer simulation of post-accident unit at the Chernobylsk NPP. Nauka, Moscow, U.S.S.R.

Masschelein, W.J.; Goossens, R.; Delville, A.; Genot, J.; Halleux, R. 1987. "Lessons to be drawn from the performance of a conventional drinking water treatment plant during fallout from the Chernobyl accident." In International symposium on the use of isotope techniques in water resources development. CONF-870310, IAEA, Vienna, Austria.

Masters, R. 1988. "Chernobyl takes the blame for delays in the Western World's nuclear programmes." Nucl. Eng. Int. 33(407):21-23.

Masters, R.; Legasov, V. 1987. "World survey: (of the nuclear industry). Chernobyl has less-than-expected impact on orders and future plans; Soviet nuclear power after Chernobyl; How the $0 E C D$ responded to Chernobyl; Country-by-country progress review-USSR and Comecon; Countr." Nucl. Eng. Int. $32(395): 25-39$.

Matsunami, T.; Ishiyama, T.; Kobashigawa, A.; Yamada, 0. 1987. "Nuclear debris from Chernobyl observed in 0saka." Annu. Rep. Radiat. Cent. 0saka Prefect. 27:v.

Matsuoka, 0. 1986. "Radiobiological Impact of Chernoble Accident on Japan and Japanese Citizen" In ICRP Committee 2. National Institute of Radiological Sciences, Tokyo.

Matteman, J.L. 1987. "Chernobyl: some origins and effects." Ingenieur $99(1): 54-61$.

Mattern, F.C.M. 1986. Radioactive contamination of drinking water in the Netherlands caused by the reactor accident at Chernobyl. Document 13. Rijksinstituut voor Volksgezondheid en Mitieuhygiene, Bilthoven, Netherlands.

Mattern, F.C.M. 1987. Supplementary measuring program for assessment of the effects of the Chernobyl accident on the Dutch people. Document 19. Rijksinstituut voor Volksgezondheid en Milieuhygiene, Bilthoven, Netherlands.

: Mat thees, W.: Buchhardt, F. 1988. "International reactor safety conference - one year after Chernobyl. Report on the 9th SMiRT conference, Lausanne, August 17-21, 1987." Amts-Mitteilungsbl. Bundesanst. Materialpruef.

$18(1): 30-32$. 
Mat thees, W.; Buchhardt, F. 1987. "Reactor safety international - one year after Chernobyl. Report about the 9 th SMIRT conference in Lausanne August 17-21, 1987. "ATW, Atomwirtsch., Atomtech. 32(11):558-559.

Matthews, D. 1986. "After Chernobyl. Pt.2." Fire Eng. 79(973):9-10.

Maushart, R. 1986. "Chernobyl and what it taught: Is our radiation protection system still trustworthy?" ATW, Atomwirtsch. Atomtech. 31(8/9):466.

Maushart, R. 1986. "Radiation protection facing difficult probiems." ATW, Atomwirtsch., Atomtech. 31(12):605-608.

Maushart, R. 1986. "Is radiation protection any longer credible - the bitter warnings from Chernoby1." Nuc Compact, Compact News Nucl. Med. 17(3):144-145.

Maushart, R. 1987. "Conference report: Twenty years experience in radiation protection - review and out look." GIT Fachz. Lab. 31(5):480-485.

McCloskey, G. 1988. "Coal - a once and future king." In 12. Uranium Institute annual symposium. Uranium Institute, London, U.K.

McCloskey, G.: Randle, S.L. (eds.) . 1987. Financial Times International Coal Report's Coal Year 1986. Financial Times Business Information Ltd., London, U.K.

McNeece, J.P.; Omberg, R.P.: Weber, E.T. 1988. A comparison of N Reactor and Chernobyl. WHC-EP-0094, West inghouse Hanford Co., Richland, WA, U.S.A.

McPherson, G.D. 1987. "Chronology of the Chernobyl-4 accident." In Radiological accidents, perspectives and emergency planning preparedness. Dept. of Energy, Washington, D.C., U.S.A.

Medveddev, Z. 1988. Soviet nuclear energy programme: the road to Chernobyl. Mackay, L.; Thompson, M. (eds.), Pluto Press, London, U.K.

Meekings, G.F. 1987. "Monitoring of radioactivity in food." In Conference on health effects of low dose ionizing radiation: recent advances and their applications. CoNF-870534, Thomas Telford, London, U.K.

Meggitt, G.C. 1988. "Emergency planning for NPP accidents." In International approach to nuclear safety seminar. Ballard, G.M. (ed.), CONF-8 806174 , Elsevier Applied Science, London, U.K.

Megumi, K.; Ito, N. 1987. "Radioactivities in airborne dust in Osaka (May, 1986)." Annu. Rep. Radiat. Cent. Osaka Prefect. 27:v.

Meieran, H.B. 1986. "Mobilization of existing robotic and teleoperated mobile vehicles to mitigate the consequences of radiological emergencies; a TMI-2 reality and a Chernobyl scenario." Trans. Am. Nucl. Soc. 53:69-70. 
Meieran, H.B. 1988. "How mobile robots have helped at Chernobyl and other accidents." Nucl. Eng. Int. 33(405):21-26.

Meieran, H.B. 1988. "Robotics and teleoperator-controlled devices." Health Phys. 55(2):215-222.

Meieran, H.B. 1987. "Mobile robot response to actions associated with the release of hazardous materials." In Radiological accidents, perspectives and emergency planning preparedness. HB Meieran Assoc., Pittsburgh, PA, U.S.A.

Melandri, C.; Castellani, C.A.; Tarroni, G.; Formignani, M.; Rampa, E.; Santori, G. 1987. "Internal contamination measurements of residents in Bologna and Rome areas up to 30/6/1987." Acqua Aria 10:1245-1250.

Melandri, C.; Castellani, C.M.; Calamosca, M.; Torroni, G.; Formignani, M.; De Zaiacomo, T. 1987. Internal and atmospheric contamination measurament by means of whole body counter performed up to 31.21 .1986 by Bologna ENEA-PAS following the Chernobyl accident. ENEA, Rome, Italy.

Melian, H. 1986. "Contamination of farming areas by air-borne radioactivity due to the accident in the Chernobyl power plant, USSR." In Meeting on after the Chernobyl accident: how safe is our food?. CoNF-8606412, Stiftung Verbraucherinstitut, Berlin, Germany, F.R.

Melieres, M.A.; Pourchet, M.; Pinglot, J.F.; Bouchez, R.; Piboule, M. 1988. "Chernobyl Cs-134, Cs-137, and $\mathrm{Pb}-210$ in high mountain lake sediment: measurements and modeling of mixing process." J. Geophys. Res. $93(D 6): 7055-7061$.

Merrett, D.J. 1986. "Safety aspects of advanced gas cooled reactors in the UK." In SVA information meeting on safety of nuclear power plants in the light of TMI and Chernobyl. Schweizerische Vereinigung fuer Atomenergie, Bern, Switzerland.

Meteorological office. 1987. Chernobyl - the radioactive plume and its consequences. Meteorological office, Bracknell, U.K.

Meyer, L.; Jacobi, A. 1987. "Safety objectives for containment protection." Nucl. Eur. 7(6-7):39-40.

Michaelis, H. 1986. Nuclear energy reference book. Vol. 1 and 2. A compendium of energy policies and the energy economy. ECON Verl., Duesseldorf, Germany, F.R.

Michaelis, H. 1986. "Energy problems today - between isolation and dependence." 0esterr. Z. Elektrizitaetswirtsch. 39(11):259-268.

Midden, C.J.; Verplanken, B. 1986. Aftermath of Chernobyl. Effects of the Chernobyl-accident on public opinion about nuclear power. Stichting Energieonderzoek Centrum Nederland, Petten, Netherlands. 
Midden, C.J.H.; Verplanken, B. 1986. After Chernobyl. Some conclusions about the effects of the Chernobyl accident on public opinion about nuclear power. Netherlands Energy Research Foundation, Petten, Netherlands.

Mijatovicj, Lj.; Brnovicj, R.; Vukoticj, M. 1987. "Radioactivity of the river waters in Serbia after Chernobyl accident." In 14. Yugoslar symposium on radiation protection. CONF-8706303, Yugoslav Radiological Protection Association, Novi Sad, Yugoslavia.

Miklayzhicj, U.; Korun, M.; Zhele, M.; Fedina, Sh.; Juzhnich, K.; Brajnik, D. 1987. "Presence of Chernobil contamination in food chain in autumn 1986 . In Brezhice-Krshko region." In 14. Yugoslav symposium on radiation protection. CONF-8706303, Yugos Tav Radiological Protection Association, Novi Sad, Yugoslavia.

Milivojevicj, K.; Ubovicj, Zh.; Trajkovicj, M.; Stojanovicj, D.; Stojanovicj, M.P. 1987. "Fast detection of internal contamination of human population after the accident at the Chernobyl nuclear power plant." In 14. Yugoslav symposium on radiation protection. Yugoslav Radiological Protection Association, Novi Sad, YugosTavia.

Miljoestyrelsen. 1986. Chernobyl accident and Denmark. Miljoestyrelsen, Copenhagen, Denmark.

Miljoestyrelsen. 1986. Chernobyl accident and Denmark. Appendices. Vol. 1. Miljoestyrelsen, Copenhagen, Denmark.

Miljoestyrelsen. 1986. Chernobyl accident and Denmark. Appendices. Vol. 2. Miljoestyrelsen, Copenhagen, Denmark.

Miljoeverndepartementet. 1986. Experience from the nuclear accident in Chernobyl. Universitetsforlaget, Oslo, Norway.

Miljoeverndepartementet. 1987. Nuclear accidents. Proposals for national and international measures. Mi 1joeverndepartenentet, Oslo, Norway.

Miller, K.M.; Geduldig, J. 1986. Measurements of the external radiation field in the New York metropolitan area. Volchok, H.L.; Chieco, N. (eds.), USDOE Environmental Measurements Lab., New York, NY, U.S.A.

Miller, R. 1988. "Chernobyl new town." Sunday Times Mag. p. 54-58.

Milne, R. 1987. "Disastrous plans for nuclear accidents." New Sci. $114(1557): 52-54$.

Milne, R. 1987. "Lessons for the Soviets." New Sci. 114(1557):37-39.

Min, B.W.; Lee, S.H.; Eun, Y.S. 1987. "Korean approach to nuclear power safety." In International symposium on nuclear safety. CONF-871291, Nuclear Safety Commission, Tokyo, Japan. 
Minghua, T.; Yifen, G.; Chengyao, S.; Changging, Y.; Dechang, W. 1988.

"Measurement of internal contamination with radioactive caesium released from the Chernobyl accident and enhanced elimination by prussian blue." J. Radiol. Prot. 8(1):25-28.

Ministerium fuer Ernaehrung. 1987. Documentation presented by the Land government of Baden-Wuerttemberg, on the impacts of the Chernobyl reactor accident and the measures taken. Vol. 1-3. Vol. 1: Impacts and measures taken. Data as of March 1987. Vol. 2: Data measured in Bade. INIS-mf-11662, Ministerium fuer Ernaehrung, Germany, F.R.

Ministerium fuer Ernaehrung. 1987. Chernobyl reactor accident and its impact on the Land Baden-Wuerttemberg. INIS-mf-11732, Ministerium fuer Ernaehrung, Germany, F.R.

Ministerium fuer Umwelt. 1987. Information on the impact of the Chernobyl reactor accident on the Land Rhineland-Palatinate. 3 . Supplement to the report of June 25, 1986. Ministerium fuer Umwelt und Gesundheit des Landes Rheinland-Pfalz, Mainz, Germany, F.R.

Ministerium fuer Umwelt. 1987. Information on the impact of the Chernobyl reactor accident on the Land Rhineland-Palatinate. 4. Supplement to the report of June 25,1986. Ministerium fuer Umwelt und Gesundheit des Landes Rheinland-Pfalz, Mainz, Germany, F.R.

Ministerium fuer Wirtschaft. 1986. Baden-Wuerttemberg energy report 1985/1986. Ministerium fuer Wirtschaft, Stuttgart, Germany, F.R.

Ministerium fuer Wirtschaft. 1987. Report of North-Rhine Westphalia's Land Government about the decision of the diet of July 10, 1986, concerning the transition to an energy supply system without nuclear electricity generation. Ministerium fuer Wirtschaft, Duesseldorf, Germany, F.R.

Ministry of Agriculture, Fisheries and Food. 1987. Chernobyl reactor accident and its impact on the aquatic environment (marine and freshwater). Ministry of Agriculture, Fisheries, and Food, Lowestoft, U.K.

Ministry of Agriculture, Fisheries and Food. 1987. Radionuclide levels in food, animals and agricultural products. Post Chernobyl monitoring in Engl and and Wales. H.M. Stationery Office, London, U.K.

Ministry of Agriculture, Fisheries and Food. 1988. Radionuclide levels in food, animals and agricultural products 1987 . Post Chernobyl monitoring in England and Wales. H.M. Stationery Office, London, U.K.

Ministry of Industry. 1986. After Chernobyl - Consequences for energy policy, nuclear safety, radiation and environmental protection. Report of the Expert Group for Nuclear Safety and the environinent. Norstedt, Stockhoim, Sweden.

Ministry of Industry. 1986. After Chernobyl. Consequences for energy policy, nuclear safety, radiation protection and environinent protection. Liber, Stockholm, Sweden. 
Mira, J.J.; Scherrer, J. 1988. "Public opinion and the safety of nuclear facilities." In International conference on nuclear power performance and safety. CONF-8709263, IAEA, Vienna, Austria.

Misaelides, P.; Sikalidis, C.: Tsitouridou, R.; Alexiades, C. 1987. "Distribution of fission products in dust samples from the region of Thessaloniki, Greece, after the Chernobyl nuclear accident." Environ. Pollut. $47(1): 1-8$.

Mitchel1, D.J. 1987. Analysis of Chernobyl fallout measured with a RAMP detector. Sandia National Labs., Albuquerque, NM, U.S.A.

Mitche11, N.T.; Camplin, H.C.; Leonard, D.R.P. 1986. "Chernobyl reactor accident and the aquatic environment of the UK: a fisheries viewpoint." $\mathrm{J}$. Soc. Radiol. Prot, 6(4):167-172.

Mitchell, N.T.: Steele, A.K. 1988. "Marine impact of caesium-134 and -137 from the Chernobyl reactor accident." J. Environ. Radioact. 6(2):163-175.

Mitchell, P.I.; Vidal-Quadras, A.; Font, J.L.; Oliva, M. 1988. "Gamma radioactivity in the Iberian marine environment closest to the NEA dumping site." J. Environ. Radioact. 6(1):77-89.

Moberg, L. 1986. "The Chernobyl Accident--Some Consequences in Sweden" In Society for Risk Analysis 1986 Annual Meeting. Swedish National Institute of Radiation Protection, Stockholm.

Molzahn, D. 1987. Marburg after Chernobyl. A documentation of measured radioactivity data compiled by the Nuclear Chemistry Department of the Physical Chemistry Faculty of Marburq University. Hitzeroth, Marburg, Germany, F.R.

Monte, L. 1987. Dynamical model predicting the transport of I-131 through the deposition pasture cow milk pathway. ENEA, Rome, Italy.

Monte, L. 1988. "Dynamic transfer model by means of experimental data collected after Chernobyl accident, for evaluating some parameters concerning the radioactive migration in the environment. Pt.1." In 4. meeting of the Italian Society for Radiation Research. ENEA-RT-PAS-87-19, ENEA, Rome, Italy.

Moore, J.S.; Chu, S.L. 1987. "Nuclear power: Past, present, and future." In Energy 187: energy solutions today for the nineties. American Society of Civil Engineers, New York, NY, U.S.A.

Morgan, K.Z. 1987. "ICRP risk estimates - an alternative view." In International conference on the biological effects of ionizing radiation. Jones, R.R.; Southwood, R. (eds.), CoNf-8611250, John wiley and Sons Inc., Chichester, U.K.

Morgenstern, F.H. 1987. "Kalkar nuclear power plant (SNR-300) - A sodium-cooled fast breeder reactor prototype." Nucl. Technol. 78(3):231-244. 
Morishima, H.: Koga, T.; Hisanaga, S. 1986. "Observations on the radioactive fallout originated from the reactor accident at Chernobyl in USSR, 1." Kinki Daigaku Genshiryoku Kenkyusho Nenpo 23:v.

Morishima, H.; Koga, T.; Hisanaga, S.; Miki, R.; Kawai, H.: Honda, Y. 1987. "Radiation hazard control report." Kinki Daigaku Genshiryoku Kenkyusho Nenpo $24: 24$.

Morison, W.G. 1986. "Chernobyl: Safety design comparisons with Ontario Hydro reactors." In 26. annual international conference of the Canadian Nuclear Association and the 7. annual conference of the Canadian Nuclear Society. The Canadian Nuclear Association, Toronto, Canada.

Morita, M.; Shoji, M.: Honda, T.; Sakanous, M. 1987. "Influence of nuclear reactor accident at Chernobyl: On the environmental radioactivity in Toyama." Radioisotopes 36(6):282-285.

Mosar, N. 1987. "Energy policy in the European Community: the state of the Union." Rev. Energ. 38(389):1-3.

Moser, E.; Roedler, H.D. 1987. "I-131 Iodine: Biokinetics, radiation exposure and risk assessment following the reactor accident at Chernobyl." Roefo, Fortschr. Geb. Roentgenstr. Nuk learmed. 146(6):711-716.

Mostert, P. 1987. "Excursion of radioactive materials caused by nuclear reactor accidents. Chapter 4." In Chernobyl - environment and health aspects. Van Loon, A.J. (ed.), KIVI-Kerntechniek, Arnhem, Netherlands.

Motte, F. 1986. "Chernobyl-4 Reactor and the possible causes of the accident." In Seminar on the Chernobyl accident and its impact. IAEA, Vienna, Austria.

Mould, R.F. 1988. Chernobyl: the real story. Pergamon Press, Oxford, U.K.

Mould, R.F. 1987. "After Chernoby1." Br. J. Radiol. 60(714):B29-B34.

Mountford, P.J.; Corfield, J.R.; Wells, C.P.; Duplock, G.; Coakley, A.J. 1986. "Consequences of Chernobyl accident for health services." Lancet $2(8514)$ : $1034-1035$.

Mourad, R.; Snel1, V. 1987. "Source term and radiological consequences of the Chernoby1 accident." Trans. Am. Nucl. Soc. 54:226-228.

Mueck, K. 1986. "Attempt at a de-confusion. Units, biological effects of radiation limits and their meaning." Agro Zucker 4:4.

Mueck, K. 1988. "Variations in activity concentration and radionuclide ratio in air after the Chernobyl accident and its relevance to inhalation dose estimates." Radiat. Prot. Dosim. 22(4):219-229. 
Mueck, K. 1987. Estimate of the radiation exposure of the Austrian population due to the reactor accident Chernobyl. Oesterreichisches Forschungszentrum Seibersdorf G.m.b.H., Vienna, Austria.

Mueck, K.; Steger, F.; Hefner, A. 1987. Radiation protection safety report of the Research Centre Seibersdorf for the year 1986. 0esterreichisches Forschungszentrum Seibersdorf G.m.b.H., Vienna, Austria.

Mueck, K.; Streit, S.; Steger, F.; Mayr, K. 1988. Dose contribution of Sr-90 to the ingestion dose after the Chernobyl accident. 0EFZS-4452, 0esterreichisches Forschungszentrum Seibersdorf G.m.b.H., Vienna, Austria.

Mueller, H. 1987. "Valuation of radionuclides using radioecological models." Dtsch. Tieraerzt 1. Wochenschr. $94(6): 367-370$.

Mueller, H.; Kahr, G.; Ninaus, W.; Oswald, K.; Rabitsch, H. 1986. After the Chernobyl accident. Heindler, M. (ed.), Technische Univ., Graz, Austria.

Mueller-Broich, A. 1986. "Radioactive fall-out from the Chernobyl disaster, and its aftermath in Central Europe." In Conference on the treatment and containment of radioactive wastes and disposal in arid environments (Radwaste '86). Ainstie, L.C. (ed.), Regensburg Univ., Germany, F.R.

Muggenburg, B.A.; Sun, J.D. (eds.). 1986. Inhalation Toxicology Research Institute: Annual report, October 1, 1985 through September 30, 1986.

Inhalation Toxicology Research Inst., Albuquerque, NM, U.S.A.

Multer, I. 1987. "Exploring the safety of Ignalina." Nucl. Eng. Int. $32(394): 21-22$.

Multhaup, H.T. 1987. "Nuclear power and nuclear insurance. Relevant effects of the Chernobyl reactor accident." Energiewirtsch. Tagesfragen $37(4): 340-341$.

Mundschenk, H.: Wengler, P. 1987. Chernobyl accident and its direct and late effects an surface bodies of water in Germany. BfG-0405, Bundesanstalt fuer Gewaesserkunde, Koblenz, Germany, F.R.

Murswiek, D. 1986. "Liability of the Federal Republic of Germany for consequences arising from nuclear accidents abroad." Umwelt-Planungsrecht $6(10): 371-379$.

Mustonen, R.; Salonen, S.; Jantunen, M.; Reponen, A.; Itkonen, A. 1988. Influence of the Chernobyl accident on radioactivity of fuel peat and peat ash in Finland. STUK-B-VALO-51, Finnish Centre for Radiation and Nuclear Safety, Helsinki, Finland.

NAEP. 1986. The Reactor Accident at Chernobyl, U.S.S.R. Radioactivity Measurements in Denmark National Agency of Environmental Protection, Copenhagen. 
NERF. 1986. "Summary of Radiological Measurements Related to the Chernobyl Accident Carried Out by the Netherland Energy Research Foundation (ECN). Petten" In NEA/OSNI Principal Working Group No. 4 Group of Experts on Accident Consequences (GRECA) meeting. Netherlands Energy Research Foundation, Petten.

Nadezhina, N.M. 1987. "Experience of a specialised centre in the organisation of medical care of persons exposed during a nuclear reactor accident." $\mathrm{Br}$. J. Radiol. $60(720): 1169-1170$.

Nair, S.: Darley, P.J. 1986. "Preliminary assessment of individual doses in the environs of Berkeley, Gloucestershire, following the Chernobyl nuclear reactor accident." J. Soc. Radiol. Prot. 6(3):101-108.

Napravnik, J.; Sazavsky, P.; Skaba, V.; Zahalka, F.; Vild, J.; Kulovany, J. 1987. "Practical results of the MESA 1 line calcinator trial operation." Nukleon 1:3-6.

Naritomi, M. 1987. "Physical and chemical behaviors of radioiodine in atmospheres from degraded core to environment following nuclear reactor accident." Hoken Butsuri 22(2): 189-207.

Naschi, G. 1986. "Safety in nuclear plants." Termotecnica 40(9):59-62.

National Inst. of Radiation Protection. 1986. Project Chernobyl. Progress report 1. National Inst. of Radiation Protection, Stockholm, Sweden.

National Inst. of Radiation Protection. 1987. Project Chernobyl. Progress report 2. National Inst. of Radiation Protection, Stockholm, Sweden.

National Inst. of Radiation Protection. 1987. Radiation doses in Sweden as a result of the Chernobyl fallout. SSI-87-13, National Inst. of Radiation Protection, Stockholm, Sweden.

National Inst. of Radiation Protection. 1986. Chernobyl - its impact on Sweden. National Inst. of Radiation Protection, Stockhoim, Sweden.

National Inst. of Radiological Sciences. 1986. Radiological survey for the tourists in USSR around the Chernobyl accident. National Inst. of Radiological Sciences, Chiba, Japan.

National Radiological Protection Board. 1987. Hork of the NRPB 1984/1986. H.M. Stationery Office, London, U.K.

National Radiological Protection Board. 1987. Corporate plan 1987/1988 to 1990/1991. National Radiological Protection Board, Chilton, U.K.

National Research Centre for the Physical Sciences Democritos. 1986. Consequences of the Chernobyl nuclear accident in Greece - Report No. 2. National Research Centre for the Physical Sciences Democritos, Athens, Greece. 
National Research Centre for the Physical Sciences Democritos. 1986. Chernobyl nuclear accident and its consequences in Greece. National Research Centre for the Physical Sciences Democritos, Athens, Greece.

Navrati1, L.; Pospisit, J.; Blehova, Z. 1987. "Clinical radiobiology and Chernobyl." Vesmir 66(12):674-675.

Navratil, L.; Pospisil, J.; Dienstbier, Z. 1987. "Lesson of Chernobyl accident for radiobiology." Cas. Lek. Cesk. 126(25):787-790.

Neu, A.; Goll, L.; Voelkle, H.; Winter, M. 1987. Strontium measurement results from the Federal Republic of Germany and from Switzerland after the Chernobyl reactor accident. Data compilation of the 'Working Group Environmental Monitoring'. Fachverband fuer Strahlenschutz e.V., Karlsruhe, Germany, F.R.

Neuhof, G.; Nowak, K. 1987. "Experience with the nuclear-reactor remote-monitoring system (RMS)." In Technical meeting and exhibition of Deutsches Atomforum e.V.: man and the chip in nuclear engineering techniques in information processing. CONF-8710358, INFORUM Verl., Bonn, Germany, F.R.

$\mathrm{Ng}$, Y.C.; Hoffman, F.0. 1987. "A comparison of model predictions and observations of the transfer of $\mathrm{Cs}-137$ through the air-pasture-cow-milk pathway." In Workshop on methods for assessing the reliability of envi ronmental transfer models predictions. Lawrence Livermore National Lab., Livermore, CA, U.S.A.

Nicholson, K.W. 1987. "Deposition of caesium to surfaces of buildings." Radiat. Prot. Dosim. 21(1-3):37-42.

Nicholson, R.A.; Nicholson, J.P.; Mould, R.F. 1986. Westminster Hospital monitoring with a single sodium iodide counter. Haywood, J.K. (ed.), Institute of Physical Sciences in Medicine, London, U.K.

Niedersaechsisches Inst. fuer Radiooekologie. 1987. 1986 annual report of the Lower Saxony Institute for Radio-Ecology at the Hanover University.

Niedersaechsisches Inst. fuer Radiooekologie.

Niedersaechsisches Inst. fuer Radiooekologie. 1987. Additional investigations within the research programme launched after the Chermobyl accident.

Niedersaechsisches Inst. fuer Radiooekologie, Germany, F.R.

Niedersaechsisches Inst. fuer Radiooekologie. 1987. Investigations into special radio-ecological issues. Niedersaechsisches Inst. fuer Radiooekologie, Germany, F.R.

Niedersaechsisches Inst. fuer Radiooekologie. 1987. Stock-taking of I-129 in human thyroids. Niedersaechsisches Inst. fuer Radiooekologie, Germany, F.R. 
Niemczyk, S.J. 1987. "In-plant chemical phenomena potentially important to nuclear reactor severe accidents and their source terms." In 192. American Chemical Society national meeting. Niemczyk, S.J. (ed.), Gull Associates, Washington, D.C., U.S.A.

Nishizawa, K.; Takata, K.; Hamada, N.; Ogata, Y.; Kojima, S.; et al. 1986. "TI in milk and rain after Chernoby1." Nature 324(6095):308.

Nixon, W. 1987. "Consequence analys is after Chernobyl." In Conference on nuclear risks - reassessing the principles and practical after Chernobyl. IBC Technical Services Ltd., London, U.K.

Nixon, W.: Egan, M.J. 1988. "Consequences of the Chernobyl accident." In International approach to nuclear safety seminar. Ballard, G.M. (ed.), CONF-8806174, Elsevier Applied Science, London, U.K.

Noguchi, H.; Murata, M. 1988. "Physjochemical speciation of airborne I-131 in Japan from Chernobyl." J. Environ. Radioact. 7(1):65-74.

Nordlund, G. 1988. Radiation doses due to long-range transport of airborne radionuclides. Final report for the period 1 December $1985-31$ January 1988. IAEA-R-4302-F, IAEA, Vienna, Austria.

Novikov, Yu.P.; Noskov, A.A.; Nesterov, A.F.; Pankrat'ev, Yu.V.; Ponomarev, I.M.: Ushakov, A.B. 1985. Measurement of deposit activity on internal surfaces of technological circuit at NPP with RBMK-1000 reactor by unsampling method. Ehnergoatomizdat, Moscow, U.S.S.R.

Novosel'skii, 0.Y.; An'kov, V.I.; Karasev, V.B.; Lyutov, M.A.; Sakovich, E.V. 1984. "Tests on improved stean separators in the third unit at the Chernobyl nuclear power station." Sov. At. Energy 57(6):807-811.

Novosel'skii, 0.Yu.; Karasev, V.B.; Sakovich, E.V.; Lyutov, M.A.; An'kov, V.I. 1984. "Testing improved steam separators in third energy block of Chernobyl AES." At. Energ. 57(6):382-385.

Nuclear Energy Agency. 1987. Chernobyl and the safety of nuclear reactors in OECD countries. OECD, Paris, France.

Nuclear Energy Agency. 1987. Electricity, nuclear power and fuel cycle in OECD countries, main data 1987. OECD, Paris, France.

Nuclear Energy Agency. 1987. NEA activities in 1986 15. Activity report of the OECD nuclear energy agency. OECD, Paris, France.

Nuclear Energy Agency. 1987. Radiological impact of the CHERNOBYL accident in OECD countries. OECD, Paris, France.

Nuclear Safety Board of Swedish Utilities. 1986. Nuclear power news No. 38. Extra issue about the Chernobyl accident. Nuclear Safety Board of Swedish Utilities, Stockholm, Sweden. 
Nuclear Safety Board of Swedish Utilities. 1986. Nuclear power news No. 39. Extra issue on account of the Chernobyl accident. Nuclear Safety Board of Swedish Utilities, Stockholm, Sweden.

0'Farrelly, C. 1987. "Containing the "incredible'" (severe-accident and containment-design studies)." In Seminar concerning safety studies on severe accident in light water reactors. EUR-11019, Electricity Supply Board, Dublin, Ireland.

OAB. 1986. A Csernobili Atomeromu Baleset Sugarzasi Kovetkezmenyei Magyarorszagon Orszagos Atomenergia Bizottsag, Budapest.

Oak Ridge National Lab. 1986. Environmental surveillance data report for the third quarter of 1986. Oak Ridge National Lab., Oak Ridge, TN, U.S.A.

Oak Ridge National Lab. 1986. Environmental surveillance data report for the second quarter of 1986. Oak Ridge National Lab, Oak Ridge, TN, U.S.A.

Oberhausen, E. 1987. "Precautionary radiological protection." Nuklearmediziner $10(5): 395-400$.

Desterreichisches Forschungszentrum Seibersdorf G.m.b.H. 1987. Final report on the radioactivity of ground, surface and waste waters, of the soil and vegetation in the control area of the research reactor Seibersdorf for 1986. INIS-mf-11109, 0esterreichisches Forschungszentrum Seibersdorf G.m.b.H., Vienna, Austria.

Desterreichisches 0ekologie-Institut fuer Angewandte Umweltforschung. 1986. Daily atom - a guide after Chernobyl. 60 days after Chernobyl. Falter Verlags Ges.m.b.H., Vienna, Austria.

Oesterreichisches Oekologie-Institut fuer Angewandte Umweltforschung. 1986. Daily radiation. 150 days after Chernobyl: food adviser and cesium map updated. Falter Verlags Ges.m.b.H., Vienna, Austria.

Okamoto, K. 1987. "Release of radioactive substances from the accident at Chernobyl. Relation with source term studies." Genshiryoku Kogyo $33(10): 27-35$.

0liveira, A.R. de. 1986. Preliminary report about nuclear accident of Chernobylsk reactor. NUCLEOS, Rio de Janeiro, Brazil.

01iver, T. 1986. "After Chernoby1. Pt.1." Fire Eng. 79(973):7, 10.

Ooe, H.; Seki, R.; Ikeda, N. 1988. "Particle-size distribution of fission products in airborne dust collected at Tsukuba from April to June 1986." J. Environ. Radioact. 6(3):219-223.

Oosterkamp, W.J. 1987. "Reactor physical and thermohydraulic aspects of the accident with unit four in Chernobyl. Chapter 3." In Chernobyl - report of the Dutch delegation. Van Loon, A.J. (ed.), KIVI-Kerntechniek, Arnhem, Netherlands. 
Oosterkamp, W.J. 1987. "Some calculations at the Chernobyl reactor." Ned. Tijdschr. Natuurkd, A 53(2-3):90-93.

Oosterkamp, W.J.; Eendebak, B.T. 1987. "Design of future nuclear power plants with inherent safety features. Chapter $15 . "$ In How can the engineer minimize the risks of nuclear power plants?. Van Loon, A.J. (ed.), KIVI-Kerntechniek, Arnhem, Netherlands.

Orchard, H.C. 1988. "What Chernobyl has taught us about emergency planning." J. Radiol. Prot. 8(1):51-54.

Orlicj, M.; Glishovicj, D. 1987. "Chernobyl accident in Sweden." In 14. Yugoslav symposium on radiation protection. CONF-8706303, Yugoslav

Radiological Protection Association, Novi Sad, Yugoslavia.

Ossenbueh T, F. 1986. Environment conservation by way of official notice or recommendations. Heymanns, Koeln, Germany, F.R.

Otway, H.; Haastrup, P.; Cannell, W. 1987. Analysis of the print media in Europe following the Chernobyl accident. EUR-11043, Commission of the European Commities, Luxembourg.

Ouvrard, R.; Hochmann, R. 1987. "Caesjum-137 body burden in the region of Vienna after the Chernobyl accident." Radiat. Prot. Dosim. 19(3):151-158.

Oxby, C.B.; Taylor, C.; Krupowicz, O.W.; Moore, S.C.; 0ldroyd, B.; Haywood, J.K. 1986. Monitoring of radioactivity in Leeds. Institute of Physical Sciences in Medicine, London, U.K.

Paakkola, 0. 1986. "Radioactivity of the Environment in Finland After the Chernoby I Accidlent" In International Radiochemical Symposium. Institute of Physical Sciences in Medicine, London, U.K.

Paakkola, 0.; Aaltonen, H.; Arvela, H. et a1. 1986. Second Interim Report, Radiation Situation in Finland from May 5 to 16, $198 \overline{6}$ Finnish Centre for Radiation and Nuclear Safety, Melsinki.

Pacyna, J.M.: Semb, A.; Johansen, 0.: Saltbones, J. 1986. Air radioactivity at selected stations in Norway after the Chernobyl reactor accident. Norsk Inst. for Luftforskning, Kjeller, Norway.

Padley, P.J. 1987. "Dialogue between the nuclear industry and environmentalists is the key." Energy World 151:7-8, 11 .

Paetschke, D. 1987. "Energy supply in Denmark and in Schleswig-Holstein. A tell-tale comparison." Energiewirtsch. Tagesfragen 37(3):212-217.

Pag-Kuhn, S.: Schmuck, 0. (eds.). 1987. Environmental policy is a joint task of all European countries. Europa Union Verl., Bonn, Germany, F.R. 
Pages, J.P.; Rouyer, J.L. 1987. "Public perception of fusion safety: Elements for a strategy." In IAEA technical committee meeting on fusion reactor safety. IAEA-TECDOC-440, CEA Centre d'Etudes Nucleaires de Saclay, France.

Papadopoulos, N.N. 1987. "Development of nuclear techniques for national requirements." In International symposium on the significance and impact of nuclear research in developing countries. IAEA, Vienna, Austria.

Papastefanou, C.; Manolopoulou, M.; Charalambous, S. 1988. "Radiation measurements and radioecological aspects of fallout from the Chernobyl reactor accident." J. Environ. Radioact. 7(1):49-64.

Papucci, C.; Delfanti, R. 1986. "Distribution of man-made radionuclides in surficial undisturbed and disturbed sediments." In OECD/NEA Seabed Working Group meet ing. Papucci, C. (ed.), CONF-8611263, OECD/NEA Seabed Working Group, Paris, France.

Pardoe, G.K.C.; Worley, N.G. 1987. "Chernobyl accident and nuclear safety in the United Kingdom." Energy World 144:7-9.

Pardoe, G.K.C.; Worley, N.G.; Allen, F.R.; Bindon, F.J.L.; Jones, P.M.S.; Lewins, J.G. 1986. "Chernobyl accident and nuclear safety in the United Kingdom." Trans. J. Br. Ceram. Soc. 85(6):6-8.

Paretzke, H.G. 1987. Dymanic, radioecological computer code ECOSYS - design, prognostic assessments, experience. Gockel, H.P. (ed.), Regensberg und Biemann, Muenster, Germany, F.R.

Paretzke, H.G. 1987. "Radio-ecology." In AGF congress on Chernobyl and the future of energy supply in the Federal Republic of Germany. Gesellschaft fuer Strahten-und Umweltforschung m.b.H. Muenchen, Neuherberg, Gemany, F.R.

Paretzke, H.G. 1988. "Impact of the Chernobyl accident on radiation protection." Health Phys. 55(2):139-143.

Paschke, M. 1986. "Danage to health not to be expected. Analysis of the radioactive immissions as a result of the Chernobyl reactor accident." Energiewirtsch. Tagesfragen $36(7): 549-557$.

Paschke, M. 1986. "Chernobyl reactor accident and its effects. Geographic distribution of radioactive immissions in the Federal Republic of Germany and in Western Europe." Gesund.-Ing. 107(5):301-305.

Patterson, W. 1987. "Nuclear watchdog finds its role." New Sci. $114(1557): 50-52$.

Patterson, W.C. 1986. "Will we ever really know the true cost of Chernobyl?" Financ. Times Energy Econ. 62:5-7.

Patterson, W.C. 1986. "In search of the peaceful atom." Energy Policy $14(3): 196-200$. 
Paul, M.; Fink, D.; Hollos, G.; Kaufman, A.; Magaritz, M.; Kutschera, W. 1987. "Measurement of I-129 concentrations in the environment after the Chernobyl reactor accident." Nucl. Instrum. Methods Phys. Res. $29(1 / 2): 341-345$.

Pau1, R. 1986. Dangerous dream: Nuclear power. With an attached short dictionary of terms in nuclear energy. Eichborn, Frankfurt am Main, Germany, F.R.

Paunescu, N.; Vata, I. 1988. "Sr-89, Sr-90 fallout from Chernobyl in the Bucharest-Magurele area." J. Radioanal. Nucl. Chem. 126(2):97-102.

Pavlovskij, 0.A.; Gusev, D.I.: Stepanova, V.D.; Grachev, M.I.; Smirennaya, V.A.; Sakharova, P.G. 1984. "Radiation impact on population from liquid discharges of NPPS in the USSR." In Radiation safety of nuclear power plants operation conference. INIS-mf-11261, Sovet Ehkonomicheskoj Vzaimopomoshchi, Moscow, U.S.S.R.

Peelle, E. 1987. "Risk-benefit perception: The research challenge." In Conference on perception of risk. Oak Ridge National Lab., Oak Ridge, TN, U.S.A.

Pelzer, N. 1986. "Transfrontier liability for nuclear events. Law in force, and reflections on future regulations." Dtsch. Verwaltungsbl.

Verwaltungsarch. $101(17): 875-883$.

Pelzer, N. 1987. "Impact of the Chernobyl accident on international nuclear energy law." Arch. Voelkerr. 25(3):294-311.

Pelzer, N. 1987. "Topical problems of nuclear third party liability law as a consequence of the Chernobyl disaster." Energiewirtsch. Tagesfragen $37(1): 81-85$.

Pelzer, N. (ed.). 1987. "Peaceful uses of nuclear energy and state frontiers in Central Europe. Proceedings." In AIDN/INLA regional conference on peaceful uses of nuclear energy and state frontiers in Central Europe. Nomos

Verlagsges, Baden-Baden, Germany, F.R.

Pendergast, M.M.; Bowman, W.W. 1988. "A tool for qualitative evaluation of atmospheric transport models using ANATEX (Across North America Tracer Experiment) data." In Evaluation of atmospheric dispersion models applied to the release from Chernobyl meeting. OP-MS-88-195, Du Pont de Nemours (E.I.) and Co., Aiken, SC, U.S.A.

Penner, S.S.; Richards, M.B. 1988. "0xidation of nuclear-reactor-grade graphite." Energy 13(6):461-468.

Perera, J. 1986. "Oeveloping countries curtail nuclear power." Electr. Rev. Int. $219(12): 52-53$. 
Perkins, R.W.; LaBrecque, J.J.; Schelenz, R.; Perkins, R.W. 1987. "Analysis of Chernobyl debris performed at the Pacific Northwest Laboratory of the USDOE." In Consultants' meeting on the determination of radionuclides in grass ecosystem samples. IAEA, Seibersdorf, Austria.

Persson, C.; Rodhe, H.; DeGeer, L.E. 1987. "Chernobyl Accident - A meteorological analys is of how radionuclids reached and were deposited in Sweden." Ambio 16(1):20-31.

Peters, H.P. 1988. "Acceptance of nuclear energy after the Chernobyl reactor accident." In Annual meeting on nuclear technology. CONF-880501, INFORUM Verl., Bonn, Germany, F.R.

Peters, W. 1986. "ENC '86 overshadowed by Chernobyl." Atom 358:2-4.

Peters, W.; Quick, J. 1987. "Assessing nuclear risks." Atom 364:8-9.

Petersen, R.C.; Landner, L.; Blanck, H. 1986. "Assessment of the impact of the Chernobyl Reactor accident on the Biota of Swedish Streams and Lakes." Ambio 6:327-331.

Petrol1, M. 1986. Report of the Federal Ministry for the Environment, Protection of Nature and Reactor Safety, on the reactor accident of Chernobyl, its repercussions, and precautions taken or to be takenincluding addenda. Deutsches Atomforum e.V., Bonn, Germany, F.R.

Petros'yants, A. 1986. "Soviet Union and the development of nuclear power. An overview of plans and the Chernobyl accident." IAEA Bull. 28(3):5-8.

Petros'yants, A.M. 1987. "Year after the Chernobyl accident." At. Energ. $62(4): 218-219$.

Petros'yants, A.M. 1986. "One more threating warning." At. Energ. 61(1):3-6.

Pexton, A.F. 1987. "Magnox reactors and advanced gas-cooled reactors." In IAEA technical committee meeting on gas-cooled reactors and their applications. South of ScotTand Electricity Board, Glasgow, U.K.

Pfeiffer, G.; Sacher, F. 1986. "Radionuclides in meat. Effect of the current disaster in Chernobyl as compared with contamination caused by nuclear weapon testing in the sixties." Fleischwirtschaft $66(10): 1488-1496$.

Pheasant, S. 1988. "Zeebrugge-Harrisburg syndrome." New Scj. 117(1596):55-58.

Phillips, D.W. 1988. "Assessment of aseismic design standards and their relevance to nuclear power plant safety." In International approach to nuclear safety seminar. Ballard, G.M. (ed.), CONF-8806174, Elsevier Applied Science, London, U.K.

Piasecki, E. 1987. "Spatial distribution of radioactive fallout in Poland." J. Radioanal. Nucl. Chem. 118(5):369-372. 
Pichlmayer, F.; Haunold, E. 1987. Radiation burden in Austria from the Chernobyl reactor accident. Oesterreichisches Forschungszentrum Seibersdorf G.m.b.H., Vienna, Austria.

Pienkowski, L.; Jastrzebski, J.; Tys, J. 1987. "Isotopic composition of the radioactive fallout in Eastern Poland after the Chernobyl accident." $\mathbf{J}$. Radioana 1. Nucl. Chen. 117(6):379-409.

Piermattei, S. 1987. "Chernobyl accident: Environmental consequences in Italy." In Conference AIRP sull'incidente di Chernobyl. Ass. It. Protezione Contro le Radiazioni, Bologna, Italy.

Pinones $0,0.1987$. "Chernobyl: one year after; radiological measurements in Chile." Nucleotecnica 7(13):23-36.

Pivcevic, P. 1986. "Chernobyl puts a block on Yugoslavia's plans." Financ. Times Energy Econ. 57:6-7.

Planinicj, J. 1987. "Seasonal variations of atmospheric radon in 0sijek." In 14. Yugoslav symposium on radiation protection. CONF-8706303, Yugoslav Radiological Protection Association, Novi Sad, Yugoslavia.

Plant, R.D. 1988. "School investigation into Chernobyl fallout." Phys. Educ. $23(1): 26-30$.

Pocock, R.F. 1987. "Nuclear power in British politics." Nucl. Eng. $28(2): 58-59$.

Pohl-Rueling, J.; Haas, 0.; Daschil, F.; Obe, G.; Natarajan, A.T.; Brogger, A.; Roscher, E. 1988. "Chernobyl fallout in Salzburg (Austria) and its effect on peripheral blood chromosomes." In International symposium on DNA repair. chromosome alterations and chromat in structure under environmental pollutions. OEFZS-4451, Salzburg Univ., Salzburg, Austria.

Pollock, C. 1986. "Chernobyl dramatizes the decommissioning problem: nuclear power's missing link." OPEC Bull. 17(5):11-15, 76.

Ponomarev-Stepnoi, N.N. 1988. "Measures taken to improve the safety of nuclear power plants in the USSR after the Chernobyl accident." In 15. water reactor safety information meeting. Heiss, A.J. (ed.), I. V. Kurchatov Institute of Atomic Energy, Moscow, U.S.S.R.

Popp, M. 1988. Nuclear energy 1988: Back to objective judgement. Mueller, W.D.; Hossner, R. (eds.), Verlagsgruppe Handelsblatt, Duesseldorf, Germany, F.R.

Porritt, J.; Gittus, J. 1988. "Nuclear power - menace or miracle." Good Housekeeping 133(4):218-219.

Pouly, J. 1986. "Economic and political energy aspects of the Chernobyl reactor accident." Bull. Assoc. Suisse Electr. 77(18):1185-1188. 
Pourchet, M.; Pinglot, J.F.: Gascard, J.C. 1986. "Northerly extent of Chernobyl contamination." Nature 323(6090):676.

Povinec, P.; Chudy, M.; Sykora, I.; Szarka, J.; Pikna, M.; Holy, K. 1988. "Aerosol radioactivity monitoring in Bratislava following the Chernobyl accident." J. Radioanal. Nucl. Chem. 126(6):467-478.

Power Reactor and Nuclear Fuel Development Corp. 1986. Summary report on the environmental monitoring around Tokai area following the accident at Chernobyl nuclear power plant. Power Reactor and Nuclear Fuel Development Corp., Tokyo, Japan.

Powers, D.A.: Kress, T.S.; Jankowski, M.W. 1987. "Chernobyl source term." Nuc 1. Saf. 28(1):10-28.

Pradetto, A. 1986. "Chernobyl and the reactions in the socialist camp." Osteuropa $36(8 / 9): A 448-A 452$.

Prakash, S.: LaBrecque, J.J.; Schelenz, R.; Perkins, R.W. 1987. "Identification and assay of radionuclides in the environmental samples following Chernobyl reactor accident." In Consultants' meeting on the determination of radionuclides in grass ecosystem samples. Bhabha Atomic Research Centre, Bombay, India.

Preston, F.S. 1988. "Food irradiation and airline catering." Aviat., Space Environ. Med. 59(4):363-366.

Pringle, D.M.; Vermeer, W.J.; Allen, K.W. 1986. "Gamma-ray spectrum of Chernobyl fallout." Nature $321(6070): 569$.

Pucelj, B. 1987. "Comparison of environmental radioactive contamination following nuclear test explosions and the reactor accident in Chernobyl." In 14. Yugoslav symposium on radiation protection. Yugoslav Radiological Protection Association, Novi Sad, Yugoslavia.

Puetz, W.; Greuel, E. 1987. "Radioactivity of eggs due to the Chernobyl reactor accident." Arch. Lebensmittelhyg. 38(3):76-80.

Pullin, M.; Forrester, P. 1986. "Impact on London of the Chernobyt accident." Lond. Environ. Bul1. 3(4):2-4.

Queirazza, G. 1987. "Post-Chernobyl monitoring of alpha and beta emitters in significant environmental components in Italy." Acqua Aria 7:873-877.

Queirazza, G.: Guzzi, L. 1987. "Post-Chernobyl radioactivity in the terrestrial environment (Italy). " Acqua Aria 7:863-872.

Queirazza, G.; Martinotti, W. 1987. "Post-Chernobyl radioactivity in environmenta1 matrices of the Po delta (Italy). "Acqua Aria 7:857-862.

Quick, J. 1988. "Safety in nuclear power." Atom 383:8-11. 
Rabin, S.M. 1986. "Medical intervention in a nuclear accident." Hosp. Pract. $11: 137-145,14$.

Radioactivity Monitoring in Lancashire (RADMIL). 1987. Second annual report of RADMIL for the period 1.4.86 to 31.3.87. Radioactivity Monitoring in Lancashire (RAOMIL), Lancaster, U.K.

Radiochemical Inspectorate. 1988. Report for 1986/87 made to the Secretary of State for the Environment, Secretary of State for Wales. H.M. Stationery office, London, U.K.

Raestrup, R.; Kundke, J. 1986. Chernobyl and the consequences. Documentation on a 'workshop on Science' broadcast by SFB on June 23-28, 1986. Sender Freies Berlín, Berlin, Germany, F.R.

Rager, G. 1987. "Reactor accident at Chernobyl and its consequences in the media." In Annual meeting on nuclear technology. IAEA, Vienna, Austria.

Ragnarsson, P.; Larsson, B.; Johansson, K.J.; Walinder, G.; Barnaby, F.; Sjoeberg, L. 1986. Chernobyl and our health. Forskningsraadsnaennden, Stockholm, Sweden.

Rahola, T.; Suomela, M. 1987. Cesium 137 in Lapps in winter 1986. Chapter 4. STUK-A-55, Finnish Centre for Radiation and Nuclear Safety, Helsinki, Finland.

Rahola, T.; Suomela, M.; Illukka, E.; Puhakainen, M.; Pusa, S. 1987. Radioactivity of people in Finland after the Chernobyl accident in 1986. Supp lement 9 to annual report STUK-A55. Finnish Centre for Radiation and Nuclear Safety, Helsinki, Finland.

Ramesh, V. 1988. "Radiolytic gas generation during nomal and accident situations in PHWRs." In Coordinated research programme meeting on investigation of fuel element cladding interaction with water coolant in power reactors. CONF-8611270, Bhabha Atomic Research Centre, Bombay, India.

Ramm, B.; Lochner, B. 1986. Radiation after Chernobyl. Ullstein, Frankfurt am Main, Germany, F.R.

Rampa, E.; Santoni, G.; Di Pietro, S. 1987. Results of the interna] contamination measurements performed after Chernobyl accident by means of Casaccia whole body counter. ENEA, Rome, Italy.

Rank, D.; Kralik, M.; Augustin-Gyurits, K.: Maringer, F.; Rajner, V.; Kurcz, I. 1987. "Investigation of sediment transport in the Austrian part of the Danube using environmental isotopes." In International symposium on the use of isotope techniques in water resources development. CONF-870310, IAEA, Vienna, Austria. 
Rantavaara, A. 1987. Radioactivity of vegetables and mushrooms in Finland after the Chernobyl accident in 1986. Supp lement 4 to annual report STUK-A55. Finnish Centre for Radiation and Nuclear Safety, Helsinki, Finland.

Rantavaara, A.; Haukka, S. 1987. Radioactivity of milk, meat, cereals and other agricultural products in Finland after the Chernobyl accident in 1986. Supplement 3 to Annual Report STUK-A55. Finnish Centre for Radiation and Nuclear Safety, Helsinki, Finland.

Rantavaara, A.; Hyvoenen, T.; Nygren, T.; Nygren, K. 1987. Radioactivity of game meat in Finland after the Chernobyl accident in 1986. Supplement 7 to Annual Report STUK-A55. STUK-A-62, Finnish Centre for Radiation and Nuclear Safety, Helsinki, FinTand.

Rass1, G.; Vorbrugg, H. 1986. "Activity concentrations of $\mathrm{Sr}-89$ and $\mathrm{Sr}-90$ in rain water." PTB-Mitt. 96(4):256.

Rassow, J. 1986. Chernobyl reactor accident. Facts, interrelations and comparative evaluations of general interest about the risks of nuclear energy. Essen Univ., Gesamthochschule, Germany, F.R.

Rassow, J. 1988. Risks of nuclear energy. Facts and relationships in the light of the Chernobyl accident. VCH Verlagsges, Weinheim, Germany, F.R.

Raunemaa, T.; Lehtinen, S.; Saari, H.; Kulmala, M. 1987. "2-10 micrometer sized hot particles in Chernobyl fallout to Finland." J. Aerosol Sci. $18(6): 693-696$.

Ray, D.L. 1987. "Nuclear power and nuclear waste: what good are they?" In 19. DOE/NRC nuclear air cleaning conference. First, M.H. (ed.), NUREG/CP-0086-VoT.2i, USDOE Assistant Secretary for Environment, Safety, and Health, Hashington, D.C., U.S.A.

Regulla, D.F. (ed.). 1987. "Minutes of the EAES symposium 'Survey of radiological consequences of the Chernobyl accident in the EAES-member states'." In EAES symposium: survey of radiological consequences of the Chernobyl accident in the EAES-member states. Gesellschaft fuer Strahtenund Umweltforschung m.b.H. Muenchen, Neuherberg, Germany, F.R.

Rehm, W.: Jahn, W. 1987. "Thermodynamic safety behaviour of the high-temperature reactor (HTR) at core overheating accidents." Brennst.-Waerme-Kraft $39(10): 452-457$.

Reimann, M. 1987. "Verification of the WECHSL code on melt-concrete interaction and application to the core melt accident." Nucl. Eng. Des. $103(1): 127-137$.

Reineking, A.; Becker, K.H.; Porstendoerfer, J.; Hicke, A. 1987. "Air activity concentrations and particle size distributions of the Chernobyl aeroso1." Radiat. Prot. Dosim. 19(3):159-163. 
Reisch, F. 1987. "Chernobyl accident - its impact on Sweden." Nucl. Saf. $28(1): 29-36$.

Renjie W. 1987. "Nuclear power and nuclear power safety. The study of the accidents at TMI and Chernobyl NPPs." Hedongli Gongcheng 8(4):1-6.

Reshetin, L.V.; Lyutov, M.A.; Bochkarev, A.L.; et al. 1985. Physical strt-up of the RBMK -1000 reactor at the Chernobylsk NPP third unit. Voronin, L.M. (ed.), Ehnergoatomizdat, Moscow, U.S.S.R.

Res1, M. 1987. "Local radiation damage in the irradiated during Chernobyl accident." Vojen. Zdrav. Listy $56(3): 125-127$.

Rest, A.; Uschakow, A.; Brunner, G.; Schmidt, C. 1986. Chernobyl and international liability. Verl. Versicherungswirtschaft, Karlsruhe, Germany, F.R.

Reyners, P. 1988. "Nuclear liability conventions: compensating the victims of a nuclear accident." --- 2:24-26.

Ribbeck, W. 1987. "Assessment of activity introduced via the drinking water after the Chernobyl reactor incident." Three $R$ Int. 26(2):136-141.

Richmond, C.R. 1987. "Population exposure from the fuel cycle: Review and future direction." In ANS topical conference on population exposure from nuclear fuel cycle. Oak Ridge National Lab., Oak Ridge, TN, U.S.A.

Richmond, C.R.; Hoffman, F.0.; Blaylock, B.G.; Eckerman, K.F.; Lesslie, P.A.; Miller, C.W. 1988. The potential use of Chernobyl fallout data to test and evaluate the predictions of environmental radiological assessment models. ORNL-6466, Oak Ridge National Lab., Oak Ridge, TN, U.S.A.

Rijksinstituut voor Volksgezondheid en Milieuhygiene. 1986. Summary progress report on radioactivity measurements after the nuclear accident at chernobyl during May 1-12, 1986. Rijksinstituut voor Volksgezondheid en Milieuhygiene, Bilthoven, Netherlands.

Rijksinstituut voor Volksgezondheid en Milieuhygiene. 1986. Second summary progress report on radioactivity measurements after the nuclear accident at Chernobyl. Rijksinstituut voor Volksgezondheid en Milieuhygiene, Bilthoven, Netherlands.

Riley, K.; Shekhdar, J.; Thomson, D.M. 1986. Measurements at Mount Vernon Hospital. Haywood, J.K. (ed.), Institute of Physical Sciences in Medicine, London, U.K.

Rininsland, H.; Smidt, D.; Trauboth, H. 1987. "Advanced robotics R+D at KfK." In 1. workshop on manipulators, sensors and steps towards mobility. Martin, T. (ed.), KFK-4316, Kernforschungszentrum Karlsruhe G.m.b.H., Germany, F.R.

Rippon, S. 1986. "What really happened at Chernobyl?" Tech. Rundsch. $78(48): 40-50$. 
Rippon, S. 1986. "Chernobyl operators mesmerized by mind-set." Mod. Power Syst. 6(12):45-53.

Rippon, S. 1987. "Nuclear power plant performance and safety." Mod. Power Syst. $7(12): 27,29,31$.

Rippon, S.; Blake, E.M.; Payne, J. 1986. "Chernobyl: the Soviet report." Nucl. News 29(13):59-66.

Rissanen, K.; Rahola, T.; Illukka, E. 1987. Radioactivity in plants and foodstuffs in Lapland 1979-1986. Chapter 3. STUK-A-55, Finnish Centre for Radiation and Nuclear Safety, Helsinki, Finland.

Roberts, L. 1987. "Radiation accident grips Goiania." Science 238:1028-1031.

Roberts, L. 1987. "Nuclear industry after Chernobyl." Biologist 4(3):118-123.

Robothom, F.P.J. 1987. "Fallout from Chernobyl." Radiat. Prot. Aust. $5(1): 19-22$.

Rocznik, K. 1987. "Radioactivity levels in the Federal Republic of Germany in Spring 1986." Naturwiss. Rundsch. 40(1):15-18.

Rodriguez, D.J. 1988. "Long range transport: Evaluation of a particle-in-cell model using sources in the US and USSR." In 17. NATO/CCMS international technical meeting on air pollution modelling and its application. UCRL-99305, Lawrence Livermore National Lab, , Livermore, CA, U.S.A.

Roed, J. 1987. "Dry deposition in rural and in urban areas in Denmark." Radiat. Prot. Dosim. 21(1-3):33-36.

Roed, J. 1987. "Run-off from and weathering of roof material following the Chernobyl accident." Radiat. Prot. Dosim. 21(1-3):59-63.

Roed, J.; Cannell, R.J. 1987. "Relationship between indoor and outdoor aerosol concentration following the Chernobyl accident." Radiat. Prot. Dosim. $21(1-3): 107-110$.

Roedler, H.D. 1986. "Uptake, distribution and retention of radioactive substances in the body and correlated radiation exposure." In Meeting on

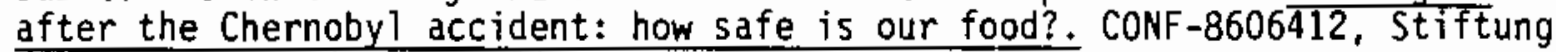
Verbraucherinstitut, Berlin, Gemany, F.R.

Roedler, H.D. 1987. "Research with radioactive materials in man." In 27. annual conference of Vereinigung Deutscher Strahlenschutzaerzte e.V. Schuetz, J.; Boerner, W.: Messerschmidt, 0. (eds.), CoNF-8605338, Thieme, Stuttgart, Germany, F.R.

Roessler, E. 1987. "Legal late-effects of Chernobyl. New liniting values for maximum permissible radioactivity." Wechselwirk. 9(35):44-47. 
Rogalla, D.; Schultz, C. 1987. "Environmentally hazardous installations near the border from the point of view of international law." Nat. Recht 9(5) : 193-199.

Rogers, F.J.; Apsey, D.; Kantor, K.: Hann, E.: Dienst, S. 1987. "Medical preparedness: Chernobyl as a model for southeastern Michigan." J. Am. Med. AssOC. 258(5):609.

Ronneau, C.: Cara, J.; Apers, D. 1987. "Deposition of radionuclides from Chernobyl to a forest in Belgium." Atmos. Environ. 21(5):1467-1468.

Roosje, G.S. 1986. Radioactivity in the food chain: report of measurements of radioactivity in the food chain in the Netherlands after the nuclear reactor accident at Chernobyl, 2 May-31 july 1986. Document 10. Rijkskwaliteitsinstituut voor Land- en Tuinbouwprodukten (RIKILT), Wageningen, Netherlands.

Rosen, M. 1986. "New directions in nuclear safety. An overview of the Agency's expanding programe." IAEA Bull. 28(3):13-15.

Rosenbaum, 0. 1987. "Classification of professionally exposed persons." In 27. annual conference of Vereinigung Deutscher Strah1enschutzaerzte e.V. Schuetz, J.; Boerner, W.; Messerschmidt, 0. (eds.), CoNF-8605338, Thieme, Stuttgart, Germany, F.R.

Rosengaus, J. 1987. Steam generators in nuclear power plants. Delphic Associates Incorporated, Falls Church, VA, U.S.A.

Roser, T. 1986. "Political landscape after Chernobyl. People and parties after the accident." Energiewirtsch. Tagesfragen 36(11):842-845.

Rossin, A.D.; Post, R.G. 1987. "Nuclear power after Chernoby1." In Waste management '87. University of Arizona Nuclear Engineering Dept., Tucson, AZ, U.S.A.

Rossnagel, A. 1986. "On the legal and economic protection for nuclear power stations. Is a 'backing-out of nuclear energy' legally possible?" Juristenzeitung $41(15 / 16): 716-720$.

Rossnagel, A. 1986. "Legal and economic protection of the existence of nuclear power plants. Is it legally feasible to back out of nuclear power?" Juristenzeitung 15/16:716-720.

Row, T.H.: Adams, W.D. 1988, "Resolving issues at the Department of Energy/0ak Ridge Operations Facilities." In Annual DOE low-level waste management conference. CONF-880839-6, Oak Ridge National Lab., Oak Ridge, TN, U.S.A.

Rowland, P. 1986. "What exploded at Chernobyl?" New Sci. 110(1511):68.

Rowland, P.R. 1986. "Chemistry of Chernobyl." Chem. Br. 22(10):907. 
Rowland, P.R. 1986. "Design of safe reactors." Chart. Mech. Eng. 33(9):51-55.

Roy, J.-C.; Cote, J.-E.; Mahfoud, A.; Villeneuve, S.; Turcotte, J. 1988. "0n the transport of Chernobyl radioactivity to Eastern Canada." J. Environ. Radioact. 6(2):121-130.

Royal Coll. of Radiologists. 1988. Consequences of the Chernobyl accident. H.M. Stationery Office, London, U.K.

Royal Swedish Academy of Engineering Sciences. 1986. "Radiation and heaTth hazards. Chernobyl in perspective." In Conference on radiation and health hazards: Chernobyl in perspective. CONF-8608133, Royal Swedish Academy of Engineering Sciences, Sweeden.

Rudzinski, K. 1986. "High temperature reactor: A missed opportunity for safety." Bild Wiss. 23(9):84-93.

Rueckert, G.; Dieh1, J.F. 1987. "Increased levels of cesium-137 and cesium-134 in 34 species of wild mushrooms following the Chernobyl disaster." Z. Lebensm, -Untersuch. -Forsch. 185:91-97.

Rufford, N. 1986. "Soviets clear the air on Chernobyl (IAEA conference report)." New Civ. Eng. 705:12-14.

Rulik, P.; Bucina, I.; Malatova, I. 1988. "Aerosol particle size distribution in dependence on the type of radionuclide after the Chernobyl accident and in the NPP effluents (poster)." In 20. international symposium on radiation protection physics. INIS-mf-11311, Institut Hygieny a Epidemiologie, Prague, Czechoslovakia.

Russell, R.; Southwood, R. 1987. Radiation versus health: Sources and effects of low-level exposure to ionising radiation. John wiley and Sons Inc., New York, NY, U.S.A.

Ryder, E.A. 1987. "Regulation of nuclear power in the UK after Chernobyl." Atom 366:8-10.

Rzymkowski, T.: LaBrecque, J.J.; Schelenz, R.; Perkins, R.H. 1987. "Information on radiological situation and activities in Poland after the Chernobyl accident." In Consultants' meeting on the determination of radionuclides in grass ecosystem samples. Central Lab. for Radiological Protection, Warsaw, Poland.

55I. 1986. Chernobyl--Its Impact on Sweden Swedish National Institute of Radiation Protection, Stockholm.

Sachs, P. 1987. "Industrial disasters - the expert systems solution." Control Syst. $4(1): 42-45$.

Sadasivan, S.; Mishra, U.C. 1986. "Radioactive fallout swipe samples from Chernoby1." Nature 324(6092):23-24. 
Saenger, E.L. 1986. "Radiation accidents." Ann. Emerg. Med. 9:1061-1066.

Saeteilyturvakeskus. 1986. Interim report on fallout situation in Finland from April 26 to May 4 1986. Saeteilyturvakeskus, Helsinkí, Finland.

Saga, T. 1988. "Energy situation in Soviet Union (Part 5). Electric utilities issues in Soviet Union." Kokusai Shigen 160:2-12.

Sagan, L.A. 1986. "Chernobyl: can it happen here?" In International conference on non-military radiation emergencies. DOE/ER/60525-1, Electric Power Research Institute, Palo Alto, CA, U.S.A.

Salo, A. 1986. "Information exchange after Chernobyl. From a radiation protection viewpoint, observations on the information flow." IAEA Bull. $28(3): 18-22$.

Salonen, L. 1987. "Carbon-14 and tritium in air in Finland after the Chernobyl accident." Radiochim. Acta 41(4):145-148.

Saltbones, J. 1986. Chernobyl reactor accident. Atmospheric transport and dispersal of radioactive substance. Norske Meteorologiske Inst., 0slo, Norway.

Saluja, S.S. (ed.). 1986. "Search for a bridge to the energy future: Proceedings." In International conference on the development of alternative energy sources and the lessons learned since the oil embargo. North Dakota Univ., Grand Forks, ND, U.S.A.

Samek, D.: Maricj, S.i Kljajicj, R.; Horshicj, E. 1987. "Some of the short-living radionuclides in the samples of grass and foliate vegetables taken at the wider area of Sarajevo after the Chernobyl accident." In 14. Yugoslav symposium on radiation protection. CONF-8706303, Yugoslav Radiological Protection Association, Novi Sad, Yugoslavia.

Sandalls, F.J. 1987. "Radiocaesium on urban surfaces after Chernobyl." Radiat. Prot. Dosim. 21(1-3):65-68.

Sanda11s, F.J.; Gaudern, S.L. 1988. "Radiocaesium on urban surfaces in West Cumbria five months after Chernobyl." J. Environ. Radioact. 7(1):87-91.

Sandberg, E.; Westerlund, R. 1986. Consumption of electric power for space heating of residential buildings and other premises. After Chernobyl. Statens Energiverk, Stockholm, Sweden.

Sands, P. (ed.). 1988. Chernobyl: law and communication. Transboundary nuclear air pollution - the legal materials. Grotius Publications Limited, Cambridge, U.K.

Sandstroem, T. 1988. Study of peat-fuel contaminated with radioactivity at Sandviken power plant. STEV-TORV-88-8, Statens Energiverk, Stockholm, Sweden. 
Sanokawa, K.; Sajto, S. 1987. "Present status of high temperature gas-cooled reactor development." Nippon Genshiryoku Gakkaishi 29(7):603-613.

Sato, K. 1987. "Sequence and causes of accident of Chernobyl nuclear power station." Nippon Genshiryoku Gakkaishi 29(1):11-14.

Sauer, G.W. 1986. "Chernobyl versus Basic Law." Neue Ges, 8:696-701.

Sauer, R. 1987. Effects of radioactivity on the living organism. Hosemann, G.; Wirth, E. (eds.), INIS-mf-11696, Erlangen-Nuernberg Úniv., Erlangen, Germany, F.R.

Sauer, R.; Schmidt, T. 1987. Radioactivity, radiation exposure and health effects of the Chernobyl reactor accident for the FRG. Hosemann, G.; Wirth, E. (eds.), INIS-mf-11696, Erlangen-Nuernberg Univ., Erlangen, Germany, F.R.

Saunders, P.A.H. 1987. Radiation. Jones, P.M.S. (ed.), John Wiley and Sons Inc., Chichester, U.K.

Savelkoul, T.J.F.; Mattern, F.C.M.; Leenhouts, H.P.; Sangster, 8.; 01denburg, S.J. 1986. Investigation for the radiation burden with $1-131$ and $\mathrm{Cs}-137$ of persons who stayed in the USSR and Poland during the nuclear reactor accident at Chernobyl. Document 15-3. Rijksinstituut voor Volksgezondheid en Milieuhygiene, Bilthoven, Netherlands.

Savolainen, A.L.; Hopeakoski, T.; Kilpinen, J.; Kukkonen, P.; Kulmala, A.; Valkama, I. 1986. Dispersion of radioactive releases following the Chernobyl nuclear power plant accident. Interim report. Finnish Meteorological Inst., Helsinki, Finland.

Sawidis, T. 1988. "Uptake of radionuclides by plants after the Chernobyl accident." Environ. Pollut. 50(4):317-324.

Saxeboe1, G.; Lundgren, L.E.; 0lerud, H.M. 1988. "Biomedical radiography and radiation." Tidsskr. Nor. Laegeforen. 108(23):1760-1764.

Saxen, R.; Aaltonen, H. 1987. Radioactivity of surface water in Finland after the Chernobyl accident in 1986. Supplement 5 to annual report STUK-A55. Finnish Centre for Radiation and Nuclear Safety, Helsinki, Fintand.

Saxen, R.; Rantavaara, A. 1987. Radioactivity of fresh water fish in Finland after the Chernobyl accident in 1986. Supplement 6 to annual report STUK-A55. Finnish Centre for Radiation and Nuclear Safety, Helsinki, Finland.

Saxen, R.; Taipale, T.K.; Aaltonen, H. 1987. Radioactivity of wet and dry deposition and soil in Finland after the Chernobyl accident in 1986. Supplement 2 to annual report STUK-A55. Finnish Centre for Radiation and Nuclear Safety, Helsinki, Finland. 
Schaefer, H, 1986. Does man end up as a final disposal site for radioactive substances. Analyses, facts, background information. Life after the Chernobyl accident - and the consequences with regard to food. Knaur, Muenchen, Germany, F.R.

Schaefer, H. 1987. "Utilization of renewable energy sources in the Federal Republic of Germany." Energiewirtsch. Tagesfragen 37(3):200-211.

Schapat, W.D. 1987. "Measuring systems for environmental radioactivity monitoring. The Chernobyl reactor accident has underlined the importance of a central register." Unwelt 3:128-129.

Schatzmann, G.P. 1987. "Transwal nuclear district heating project." Three R Int. 26(9):590-593.

Scheer, J. 1987. "How many Chernobyl fatalities?" Nature 326(6112):449.

Scheer, J. 1987. "Year one after Chernobyl." Wechselwirk. 9(33):42-45.

Scheer, J.; Fremlin, J.H. 1987. "How many Chernobyl fatalities; and reply." Nature 329(6140):589-590.

Scheer, J.; Hirsch, H.; Paul, R.; Weidmann, B.; Pelster, M.; Wallenschus, M. 1986. Is nuclear power at the end of the rope? (3rd Edition). Verl. Die Werkstatt, Goettingen, Germany, F.R.

Schelenz, R.; Abdel-Rassoul, A.A. 1986. "Report from Seibersdorf: Post accident radiological measurements. Data from the Agency's Laboratory in Austria." IAEA Bu1T. 28(3):23-26.

Schlaefer, H. 1986. "Chernobyl - facts and conclusions." Brandschutz-Dtsch. Feuerwehrztg. 40(7):248-252.

Schlenker, R.A.; 01tman, B.G.; Lucas, H.F. 1987. "Internally deposited fallout from the Chernobyl reactor accident." In Joint meeting of the American Nuclear Society and the Atomic Industrial Forum. Argonne National Lab., IL, U.S.A.

Schlesinger, T. 1986. Contamination of the Environment and Exposure of the Public in Israel Following the Chernobyl Accident Argonne National Lab., IL, U.S.A.

Schlesinger, T.; Biran, T.; Even, D.; Dukhan, R.; Shamai, Y.; Tal, A.; Friedman, K.; Koch, J. 1987. "Environmental contamination related to the Chernobyl accident as measured in Israel during May-July 1986." In Israel Health Physics Society annual meeting. Israel Atomic Energy Commission, Yavne, Israel.

Schlesinger, T.; Biran, T.; Even, 0.; Dukhan, R.; Tal, A.; Friedman, K.; Israeli, M. 1987. Environmental contamination measured in Israel following the Chernoby? reactor accident. Israel Atomic Energy Commission, Tel Aviv, Israel. 
Schlesinger, T.; Biran, T.I.; Even, 0.; Dukhan, R.; Shamai, Y.; Koch, J.; Tal, A.; Israeli, M. 1987. Monitoring data related to the Chernobyl accident as measured in Israel during May-July 1986 and the assessment of the radiation doses to the population. Israel Atomic Energy Commission, Yavne, Israel.

Schmid, H.L. 1988. "Energy scenarios." Bull. Schweiz. Elektrotech. Ver. $79(10): 561-567$.

Schmidt, F.W. 1987. "Uses of nuclear energy and state frontiers from the point of view of the neighbouring state." In AIDN/INLA regional conference on peaceful uses of nuclear energy and state frontiers in Central Europe. Pelzer, N. (ed.), Nomos Verlagsges, Baden-Baden, Germany, F.R.

Schmidt, M. (ed.). 1987. Mean radiation load and risk for human health in the Federal Republic of Germany as a result of the reactor accident in Chernobyl. IFEU-49, Verl. Das Wunderhorn, Heidelberg, Germany, F.R.

Schmidt, M. (ed.). 1987. New EC limit values for radioactivity. IFEU-49, Verl. Das Wunderhorn, Heidelberg, Germany, F.R.

Schmidt, M. (ed.). 1987. Radiological risk of the Chernobyl reactor accident. Three studies of the Heidelberg IFEU Institute on the present and future effects of the Chernobyl reactor accident. IFEU-49, Ver1. Das Wunderhorn, Heidelberg, Germany, F.R.

Schmidt, M.; Giegrich, J. 1986. Soil contamination in Hesse as a consequence of the Chernobyl reactor accident. Institut fuer Energie-und Umweltforschung e.V., Heidelberg, Germany, F.R.

Schmidt, M.; Giegrich, J.; Franke, B. 1986. Soil and grass contamination with cesium in South Germany and the winter feed 1986/1987. IFEU-Eigenverlag, Heidelberg, Germany, F.R.

Schmitt, A, 1988. Precautionary radiation protection and disaster services. Laws, regulations, skeleton recommendations and guidelines for precautionary protection of the population. Textbook presenting excerpts from the 'Handbook of civil defence, emergency. Heymanns, Koeln, Germany, F.R.

Schmitt, D. 1987. Federal Republic of Germany. Jones, P.M.S. (ed.), John Wiley and Sons Inc., Chichester, U.K.

Schneider, H. 1987. "Energy supply in the European Community. A retrospective view." Energiewirtsch. Tagesfragen 37(10):831-833.

Schneider, H.J.; Stoll, J. 1986. "Compensation of damage to property in the Federal Republic of Germany after the Chernobyl accident." Betr.-Berat. $19: 1233-1237$.

Schneider, M. 1987. "Breeder bombs out." SCRAM: Anti-Nucl. Safe Energy J. $61: 16-17$. 
Schneider, P.; Dierich, M.P.; Tiefenbrunner, F.; Brunner, P. 1986.

"Enrichment of radioactive nuclides in sewage sludge." Forum Staedte-Hyg. $37(5): 335-337$.

Schnell, R.C.; Rosson, R.M. 1987. Geophysical monitoring for Climatic Change Number 15. Summary report 1986. National Oceanic and Atmospheric Administration, Boulder, CO, U.S.A.

Schoenfeld, W. 1986. "Radioactive beams - what do the measuring units mean? Questions and some answers after the Chernobyl reactor accident." In Meeting on after the Chernobyl accident: how safe is our food?. CoNF-8606412, Stiftung Verbraucherinstitut, Berlin, Germany, F.R.

Schoenhofer, F.: Ecker, W.; Hojesky, H.; Junger, W.; Kienz1, K.; Nowak, H.; Riss, A. 1986. Chernobyl and its consequences for Austria. Bundesministerium fuer Gesundheit und Umweltschutz, Vienna, Austria.

Schoenhofer, F.; Weisz, J. 1987. "Measurement by ultra low level liquid scintillation counting following the Chernobyl accident." J. Radioanal. Nucl. Chem. 115(1):125-140.

Schoer, J. 1988. "Investigation of transport-processes along the Elbe river using Chernobyl radionuclides as tracers." Environ. Technol. Lett. $9(4): 317-324$.

Schubert, P.; Behrend, U. 1987. "Investigations of radioactive particles from the Chernobyl fall-out." Radiochim. Acta 41(4):149-155.

Schuettelkopf, H.; Wicke, A. 1986. Reactor accident of Chernobyl. Exposure dose of the population in the Karls ruhe region. Kernforschungszentrum Karlsruhe G.m.b.H., Germany, F.R.

Schuetz, J.; Boerner, W.; Messerschmidt, 0. (eds.). 1987. "Radiation protection after Chernobyl. Ionizing radiation: Results, concepts, regulations." In 27. annual conference of Vereinigung Deutscher Strahlenschutzaerzte e.V. CoNF-8605338, Thieme, Stuttgart, Germany, F.R.

Schulze-Fielitz, H. 1987. "Status protection in administrative law. With special reference to building, immission prevention and nuclear law." Verwaltung 19(3):307-335.

Schwab, R.G. 1987. Exposure to natural radiation from the earth's crust, atmosphere and outer space - the natural radioactivity of the earth's crust. Hosemann, G.; Wirth, E. (eds.), INIS-mf-11696, Erlangen-Nuernberg Univ., Erlangen, Germany, F.R.

Schwach, G. 1986. "Radioactivity measurements." Hobby Elektron. 42(12):24-26.

Schwarz, D.; Garribba, S.; Sarlos, G. 1987. "THTR operating experience." In Seminar on small and medium-sized nuclear reactors: safety and licensing issues. EPFL, Lausanne, Switzerland. 
Schwarze, J. 1986. "Legal protection of private persons in the case of acts of foreign states contrary to international law - with special reference to international environmental law." Arch. Voelkerr. 24(4):408-433.

Schweitzer, D.G.; Gurinsky, D.H.; Kaplan, E.; Sastre, C. 1987. A safety assessment of the use of graphite in nuclear reactors licensed by the US NRC. Brookhaven National Lab., Upton, NY, U.S.A.

Schwibach, J. 1986. Consequences of the Chernobyl reactor accident for the Munich area. Bundesgesundheitsamt, Neuherberg, Germany, F.R.

Scotford, G.B. 1987. "Fire in the nuclear power industry: the historical perspective." Nucl. Eng. 28(1):3-4.

Scott, B.R. 1988. "Radiation protection approach to assessing population risk for threshold-type radiobiological effects." Health Phys. 55(2):463-470.

Seaward, M.R.D.; Heslop, J.A.; Green, D.; Bylinska, E.A. 1988. "Recent levels of radionuclides in lichens from southwest Poland with particular reference to $\mathrm{Cs}-134$ and Cs-137." J. Environ. Radioact. 7(2):123-129.

Seitz, M. 1987. What did change in the FRG after the Chernobyl reactor accident? On the situation in churches. Hosemann, G.; Wirth, E. (eds.), INIS-mf-11696, Erlangen-Nuernberg Univ., Erlangen, Germany, F.R.

Selby, J.M.; Vallario, E.J.; Moeller, D.W.; Stephan, J.G. 1987. "Use of radiological accident experience in establishing appropriate perspectives in emergency planning." In American Nuclear Society annual meeting. Pacific Northwest Lab., Richland, WA, U.S.A.

Seo, T. 1988. "Radioactivity release from the Chernobyl-4 reactor accident." Hoshasen $14(2): 3-16$.

Seo, T.; Imanaka, T.; Koide, H. 1988. "Radioactivity released in Chernobyl accident." Kagaku 58(2):108-117.

Service Central de Protection contre les Rayonnements Ionisants. 1987. Monthly results of measurements, March 1987, with supplement related to 1987 first quarter. Service Central de Protection contre les Rayonnements Ion isants, France.

Service Central de Protection contre les Rayonnements Ionisants. 1986. Monthly results of measurements, July 1986. Service Central de Protection contre les Rayonnements Ionisants, France.

Service Central de Protection contre les Rayonnements Ionisants. 1987. Monthly results of measurements, August 1987. Service Central de Protection contre les Rayonnements Ionisants, France. 
Service Central de Protection contre les Rayonnements Ionisants. 1987. Monthly results of measurements, July 1987. Service Central de Protection contre les Rayonnements Ionisants, France.

Service Central de Protection contre les Rayonnements Ionisants. 1986. Monthly results of measurements, November 1986. Service Central de Protection contre les Rayonnements Ionisants, France.

Service Central de Protection contre les Rayonnements Ionisants. 1987. Monthly results of measurements. December 1987 with supplement related to 1987 last quarter. SCPRI-RM-12-1987, Service Central de Protection contre les Rayonnements Ionisants, France.

Service Central de Protection contre les Rayonnements Ionisants. 1987. Monthly results of measurements, January 1987. Service Central de Protection contre les Rayonnements Ionisants, France.

Service Central de Protection contre les Rayonnements Ionisants. 1988. Monthly results of measurements, January 1988. SCPRI-RM-1-1988, Service Central de Protection contre les Rayonnements Ionisants, France.

Service Central de Protection contre les Rayonnements Ionisants. 1986. Monthly results of measurements, June 1986 with supplement related to the three months April, May, and June 1986. Service Central de Protection contre Tes Rayonnements Ionisants, France.

Service Central de Protection contre les Rayonnements Ion isants. 1986. Results of special radiation measurements resulting from the Chernobyl accident and regional analysis of environmental radioactivity. Service Central de Protection contre les Rayonnements Ionisants, France.

Service Central de Protection contre les Rayonnements Ionisants. 1987. Monthly results of measurements, June 1987, with supplement related to 1987 second quarter. Service Central de Protection contre les Rayonnements Ionisants, France.

Service Central de Protection contre les Rayonnements Ionisants. 1986. Monthly results of measurements, May 1986. Service Central de Protection contre les Rayonnements Ionisants, France.

Service Central de Protection contre les Rayonnements Ionisants. 1987. Monthly results of measurements, May 1987. Service Central de Protection contre les Rayonnements Ionisants, France.

Service Central de Protection contre les Rayonnements Ionisants. 1987. Monthly results of measurements April 1987. Service Central de Protection contre Tes Rayonnements Ionisants, France.

Service Central de Protection contre les Rayonnements Ionisants. 1986. Monthly results of measurements, October 1986. Service Central de Protection contre les Rayonnements Ionisants, France. 
Service Central de Protection contre les Rayonnements Ionisants. 1987. Monthly results of measurements, November 1987. SCPRI-RM-11-1987, Service Central de Protection contre les Rayonnements Ionisants, France.

Service Central de Protection contre les Rayonnements Ionisants. 1986. Monthly results of measurements, September 1986, with supplement related to the three months, July, August, September 1986. Service Central de Protection contre les Rayonnements Ionisants, France.

Service Central de Protection contre les Rayonnements Ionisants. 1987. Monthly results of measurements, October 1987. SCPRI-RM-10-1987, Service Central de Protection contre les Rayonnements Ionisants, France.

Service Central de Protection contre les Rayonnements Ionisants. 1986. Monthly results of measurements, August 1986. Service Central de Protection contre les Rayonnements Ionisants, France.

Service Central de Protection contre les Rayonnements Ionisants. 1987. Monthly results of measurements, September 1987 with supplement related to 1987 third quarter. Service Central de Protection contre les Rayonnements Ionisants, France.

Shapar, H.K. 1988. "Role of nuclear energy in OECD countries." In International conference on nuclear power performance and safety. CONF-8709263, IAEA, Vienna, Austria.

Shapar, H.K.: Reyners, P. 1987. "Nuclear third party liability: the challenge of Chernobyl." Nucl. Eng. Int. 32(396):25-26.

Shepherd, L.R. 1988. "Modular high-temperature gas-cooled reactor." Nucl. Energy $27(1): 37-47$.

Shepherd, L.R. 1987. "Future of atomic energy." Interdiscip. Sci. Rev. $12(3): 257-264$.

Shimasaki, T.; Okumura, Y. 1987. "Radioactive fallout in Nagasaki from the reactor accident at Chernobyl." Nagasaki Igakkai Zasshi 62(3):468-478.

Shizuma, K.; Iwatani, K.; hasai, H. 1987. "Observation of fallout in Hiroshima caused by the reactor accident at Chernobyl." Int. J. Radiat. Biol. $51(2): 201-207$.

Shizuma, K.; Iwatani, K.; Hasai, H.; Kiso, Y.; Nishiyama, F.; Hoshi, M.: Sawada, S. 1986. "Observation of radioactive fallout in Hiroshima caused by the reactor accident at Chernobyl." Hiroshima Daigaku Kogakubu Kenkyu Hokoku $35(1): 19-28$.

Shul'tsev, D.N.; Egorov, M.F.; Kuz'min, E.S.; Sidorov, A.A. 1982. "Stressed-deformed state and vibration resistance of the RBMK-1000 reactor collectors and pipes at the Leningrad, Kursk and Chernobyl NPPs." Energomashinostroenie 5:7-9. 
Shul'tsev, D.N.; Egorov, M.F.; Kw'min, Yu.S.; Sidorov, A.A. 1982. "State of stress and strain and vibration resistance of manifolds and tube assemblies of the RMBK-1000 plant exemplified by Leningrad, Kursk and Chernobyl nuclear power plants." Energomashinostroenie 5:7-9.

Sibley, C.B. 1987. Chernobyl - the Pandora syndrome. Journal of Practical Civil Defence, Waddington, U.K.

Sidorenko, V.M.; Kosheleva, S.I.; Ryabov, A.K. 1983. "Formation of water chemical composition in the coolant pond of the Chernobylsk atomic power station." Gidrobiol. Zh. 19(4):67-70.

Siebert, H. 1987. "German energy supplies and the conditions they depend on." Z. Energiewirtsch. 11(1):13-17.

Sieker, E.; Kollert, R. (eds.). 1987. Chernobyl and the consequences. Vol. 2. Information and analyses. Lamuv, Bornheim-Merten, Germany, F.R.

Silagi, M. 1987. "International law obligations of the licensing state in case of incidents and accidents." In AIDN/INLA regional conference on peaceful uses of nuclear energy and state frontiers in Central Europe. Pelzer, N. (ed.), Nomos Verlagsges, Baden-Baden, Germany, F.R.

Silver, E.G. (ed.). 1987. Nuclear Safety: Technical progress review, October-December 1987. Oak Ridge National Lab., Oak Ridge, TN, U.S.A.

Silver, E.G. (ed.). 1987. Nuclear Safety: Technical progress review, January-March 1987. Oak Ridge National Lab., Oak Ridge, TN, U.S.A.

Simn, K.J. 1986. "Chernobyl: a first report." Nucl. Eng. 27(3):74-77.

Simnonds, J. 1987. "Europe calculates the health risk." New Sci. $114(1557): 40-43$.

Simmonds, J.R. 1987. "Remotely organized estimation of the radiation situation in Eastern Europe following the Chernobyl accident." In 'Chernobyl - a technical appraisal' seminar. British Nuclear Energy Society, London, U.K.

Sinclair, W.K. 1988. "Trends in radiation protection--a view from the National Council on Radiation Protection and Measurements (NCRP)." Health Phys. 55(2):149-157.

Sinkko, K.; Aaltonen, H.; Mustonen, R.; Taipale, T.K.; Juutilainen, J. 1987. Airborne radioactivity in Finland after the Chernobyl accident in 1986. Supplement 1 to annual report STUK-A55. Finnish Centre for Radiation and Nuclear Safety, Helsinki, Fintand.

Sjoequist, E.; Eckered, T. 1986. World after Chernobyl. What does the nuclear accident mean to us? Timbro, Stockholm, Sweden. 
Skjoeldebrand, R. 1987. "Nuclear power: status and trends." Energy Explor. Exploit. 5(5-6):363-384.

Slinn, W.G.N.; Brodzinski, R.L.; Busness, K.M.; Dana, M.T.; Davis, W.E.; Elderkin, C.E. 1987. Field studies of the atmospheric processing of radionuclides released at Chernobyl. Pacific Northwest Lab., Richland, WA, U.S.A.

Smallman, H.; Lihou, D. 1987. "Control of very serious reactor accidents." In Conference on nuclear risks - reassessing the principles and practical after Chernobyl. IBC Technical Services Ltd., London, U.K.

Smart, I. 1986. Nuclear fuel and power: a view towards 2000. I an Smart, Richmond, U.K.

Smart, I. 1986. "Nuclear power and the public." Energy Focus 3(3):152-159.

Smith, D.M.; McAllister, G.; Gemill, J.: Welham, D.: MacLennan, S. 1988. Environmental radioactivity surveillance programme: results for the UK for 1985 and 1986. NRPB-R-220, Rutherford Appleton Lab., Chitton, U.K.

Smith, D.R.; Luckhurst, D.P.; Maccabee, A.R. 1987. "Design and control characteristics of the RBMK reactor." In Chernobyl - a technical appraisal' seminar. British Nuclear Energy Society, London, U.K.

Smith, F.B.; Clark, M.J. 1986. "Radionuclide deposition from the Chernobyl cloud." Nature 322(6081):690-691.

Smith, R.D. 1987. "Overview of conference (on fast reactor safety)." In Conference on the science and technology of fast reactor safety. British Nuclear Energy Society, London, U.K.

Smith, R.E. 1988. "Safety and emergency systems following Chernobyl." VGB Kraftwerkstech. 68(4):374-378.

Smith, R.R. 1987. "Integral fast reactor and its role in a new generation of nuclear power plants." In International nuclear engineering symposium on the development and use of small and medium size power reactors in the next generation. CONF-8611129, Tokai Univ., General Research Organization, Tokyo, Japan.

Smits, F.; Carena, A. 1986. "Platform operation." In OECD/NEA Seabed Working Group meeting. Papucci, C. (ed.), CONF-8611263, OECD/NEA Seabed Working Group, Paris, France.

Snihs, J.0. 1986. Consequences in Sweden of the Chernobyl accident. National Inst. of Radiation Protection, Stockholm, Sweden.

Sobajima, M.; Fujishiro, T. 1988. "Examination of the destructive forces in the Chernobyl accident based on NSRR experiments." Nucl. Eng. Des. $106(2): 179-190$. 
Sobnack, R.: Haywood, J.K. 1986. Retention of fission products in air fiTters. Institute of Physical Sciences in Medicine, London, U.K.

Soda, K.; Muramatsu, K. 1987. "Computer conference, 'Chernobyl: Where do we 90 from here?' An example of computer-aided-conference." Joho No Kagaku To Gijutsu $37(7): 267-273$.

Soeder, C.J.; Zanders, E.; Raphael, T. 1986. "Radioactive contamination of sewage sludge. Preliminary data." Korrespondenz Abwassar, KA 33(6):472-473.

Soeldner-Rembold, S. (ed.). 1986. Political strategies concerning technological development after Chernobyl. SP-Verl., Marburg, Germany, F.R.

Soerensen, B. 1986. Chernobyl accident: Assessing the data. Roskilde Universitetscenter, Denmark.

Soerensen, B. 1987. "Chernobyl accident: Assessing the data." Nuc1. Saf. $28(4): 443-447$.

Sokolowski, E. 1988. "Can fear of nuclear power be met with rational arguments?" Nucl. Eur. 8(8-9):37-38.

Soper, K.; Ryle, M. 1988. Alternative detente. Mackay, L.; Thompson, M. (eds.), Pluto Press, London, U.K.

Sosialdepartementet. 1986. Information crises. Universitetsforlaget, 0s 10, Norway.

Sosialdepartementet. 1987. Chernobyl accident. Universitetsforlaget, Os 1o, Norway.

South of Scotland Electricity Board. 1987. Here be no dragons. A guide to the realities of nuclear power in Scotland. South of Scotland Electricity Board, Glasgow, U.K.

Southwood, R. 1987. "Concluding remarks." In International conference on the biological effects of ionizing radiation. Jones, R.R.; Southwood, R. (eds.), CONF-8611250, John Wi Tey and Sons Inc., Chichester, U.K.

Speelman, J.E. 1987. "Development of safety analyses for nuclear power plants. Chapter 11." In How can the engineer minimize the risks of nuclear power plants?. Van Loon, A.J. (ed.), KIVI-Kerntechniek, Arnhem, NetherTands.

Springer, K. 1988. "Experience with remote monitoring systems for nuclear power plants." In International conference on nuclear power performance and safety. CONF-8709263, IAEA, Vienna, Austria.

Spurny, F. 1987. "VII. National symposium on radiation dosimetry." Jad. Energ. $33(8-9): 349-351$. 
Spurny, Z.; Sulcova, J.; Hava, L. 1987. "Long-term increase in exposure rate on the Luznice natural radiation reference field in 1986 and one of the probable causes of considerably inconsistent planar contamination in the CSSR following the Chernobyl nuclear power plant accident." Radioaktiv. Zivotn. Prost. 10(3):111-117.

Staatliche Lehr-und Versuchsanstalt fuer Viehhaltung. 1986. 2nd animal experiment to determine radioactivity in milk and meat (winter feed). Staatliche Lehr-und Versuchsanstalt fuer Viehhaltung, Aulendorf, Germany, F.R.

Staatliches Amt fuer Atomsicherheit und Strahlenschutz. 1987. Results of radiation monitoring in the Geman Democratic Republic after Chernobyl. Staatliches Ant fuer Atomsicherheit und Strahlenschutz, Berlin, Germany, D.R.

State of Washington Office of Radiation Protection. 1986. OSHS Activities Relating to the Chernobyl Nuclear Accident State of Washington Department of Social and Health Services, Olympia, WA.

Statens Energiverk. 1987. After Chernobyl. Possibilities of phasing out nuclear power in Sweden. STEV-1987-4, Statens Energiverk, Stockholm, Sweden.

Statens Energiverk. 1986. Effect of a phase out of nuclear power in OECD countries on demand for fossil fuel and on sulfur precipitation in Sweden. After Chernobyl. Statens Energiverk, Stockholm, Sweden.

Statens Energiverk. 1986. Fresh production of electric power when accelerating nuclear power phaseout PFBC. After Chernobyl. Statens Energiverk, Stockholm, Sweden.

Statens Energiverk. 1986. Industry's use of electric power. After Chernobyl. Statens Energiverk, Stockholm, Sweden.

Statens Energiverk. 1986. Means of supply of extremely low-sulphur oil to the power plants of Stenungsund and Karlshamn. After Chernobyl. Statens Energiverk, Stockholm, Sweden.

Statens Energiverk. 1986. Natural gas - an alternative. Swedish electric power from Norwegian natural gas. After Chernobyl. Statens Energiverk, Stockholm, Sweden.

Statens Energiverk. 1986. New production of electric power when accelerating nuclear power phaseout. After Chernobyl. Statens Energiverk, Stockholm, Sweden.

Statens Energiverk. 1986. Premature nuclear power phaseout in Sweden. After Chernobyl. Statens Energiverk, Stockholm, Sweden.

Statens Energiverk. 1986. Premature phaseout of the Barsebaeck plant. After Chernobyl. Statens Energiverk, Stockholm, Sweden. 
Statens Inst. foer Folkhaelsan. 1986. Reactor accident at Chernobyl, U.S.S.R. Radiation measurements in Denmark. 2. report. Statens Inst. foer Folkhaelsan, Stockholm, Sweden.

Statens Inst. foer Folkhaelsan. 1986. Reactor accident at Chernobyl, U.S.S.R. Radiation measurements in Denmark. 3. report. Statens Inst. foer Folkhaelsan, Stockholm, Sweden.

Statens Inst. foer Folkhaelsan. 1986. Reactor accident at Chernobyl, U.S.S.R. Radiation measurements in Denmark. Statens Inst. foer Folkhaelsan, Stockholm, Sweden.

Statens Inst. for Straalehygiene. 1986. Estimates of radiation doses to the population from fallout in Norway the first two weeks after the reactor accident in USSR. Statens Inst. for Straalehygiene, Oslo, Norway.

Stauffer, T. 1987. "0il and nuclear power: the dynamic interrelationship." In 11. annual symposium of the Uranium Institute. Uranium Institute, London, U.K.

Steeg, H. 1987. "World energy prospects and the role of nuclear power." In 11. annual symposium of the Uranium Institute. Uranium Institute, London, U.K.

Steffens, W.; Mittelstaedt, W.; Fuehr, F.: Foerstel, H.; Klaes, J. 1986. "Chernobyl accident: Estimate of the uptake through the roots by vegetables of the cesium-137 and strontium-90 deposited after Chernobyl. Transfer of Cs-137 and Sr-90 in the soil." ATW, Atomwirtsch., Atomtech. 31(7):389-392.

Steger, F.; Henrich, E. 1986. Results of an intercomparison of gamma spectrometers in Austria; volume source TUCs and TXCS A-1986. Desterreichisches Forschungszentrum Seibersdorf G.m.b.H., Vienna, Austria.

Steiner, R. 1987. "Radioactive pollution. Comparison of the actual load of radioactivity after Chernobyl with calculation models in the Radiation Protection Ordinance." Umwelt 11/12:488-490.

Steinmetz, E. (ed.). 1987. "Nuclear power plants: Results of recent safety analyses." In 10. GRS expert's meeting on results of new safety analyses. Vulkan-Ver1., Essen, Germany, F.R.

Stenke, L.; Axelsson, B.; Ekman, M.; Larsson, S.; Reizenstein, P. 1987. "Radioactive iodine and cesium in travellers of different parts to Europe after the Chernobyl accident." Acta Oncol. 26(3):207-210.

Stern, J. 1987. "UK energy issues 1987-92." Energy Policy 15(6):498-502.

Stevenson, L. 1986. "Chernobyl reaction." SCRAM: Anti-Nucl. Safe Energy J. $54: 8-9$.

Stierstadt, K. 1987. "Investigations on radioactive fallout. Part, 14." Kerntechnik 51(1):52-54. 
Stieve, F.E. 1987. "Acceptance of radiation hazards." In 27. annual conference of Vereinigung Deutscher Strahlenschutzaerzte e.V. Schuetz, J.; Boerner, W.: Messerschmidt, 0. (eds.), CoNF-8605338, Thieme, Stuttgart, Germany, F.R.

Stiftung Verbraucherinstitut. 1986. "Half-life. After the Chernobyl accident: How safe is our food? Proceedings." In Meeting on after the Chernobyl accident: how safe is our food?. CONF-8606412, Stiftung Verbraucherinstitut, Berlin, Germany, F.R.

Stockdale, H.R.; Wood, J.; Grime, J.S.; McCormack, B.; Sztanko, K.; Henshaw, E.T.; Lewis, M. 1986. Practical difficulties associated with the assessment of internal and external radioactive contamination and its resulting dosimetry. Institute of Physical Sciences in Medicine, London, U.K.

Stoeber, I. 1987. "Radioactivity in surface waters and its effects." In 20. Essen meeting: water management in the field of tension of environmental protection. Boehnke, B. (ed.), INIS-mf-11836; CoNF, Ministerium fuer Umwelt, Germany, F.R.

Stoop, P.M.; Van den Bogaard, J.P.A.; Woudstra, A.; Koning, H. 1988. "Application of RELAP5/M0D2 for determination of accident management procedures." In 15. water reactor safety information meeting. Weiss, A.J. (ed.). NUREG/CP-0091-Vol.5, Netherlands Energy Research Foundation, Petten, Netherlands.

Stoutjesdijk, J.F. 1986. Increase of the exposure rate in the Netherlands caused by the reactor accident at Chernobyl. 0ocument 7. Rijksinstituut voor Volksgezondheid en Milieuhygiene, Bilthoven, Netherlands.

Stoutjesdijk, J.F. 1986. Radioactive contamination of the air in the Netherlands after the reactor accident at Chernobyl. 0ocument 4. Rijksinstituut voor Volksgezondheid en Milieuhygiene, Bilthoven, Netherlands.

Strahlenschutzkommission (SSK) beim Bundesminister fuer Unwelt, Naturschutz und. 1987. Chernobyl reactor accident and its consequences for the Federal Republic of Germany. Radioactivity concentrations in the F.R.G.. recommendations for limiting the radiation exposure, radiation exposure of the population and relevant assessmen. Fischer, Stuttgart, Germany, F.R.

Strahlenschutzkomnission (SSK) beim Bundesminister fuer Umwelt, Naturschutz und. 1987. Recommendations of the Strahlenschutzkommission (Radiation Protection Commission), 1985/1986. Fischer, Stuttgart, Germany, F.R.

Strand, T. 1987. Doses to the Norwegian population from naturally occuring radiation and from the Chernobyl fallout. NEI-NO-48, Fysisk Inst., Oslo, Norway. 
Strand, T.; Strand, P.; Baarli, J. 1987. "Radioactivity in foodstuffs and doses to the Norwegian population from the Chernobyl fall-out." Radiat. Prot. Dosim. 20(4):221-229.

Strand, T.; Stranden, E. 1987. "Indoor gamma radiation in Norwegian dwellings during the first three months after the Chernobyl accident." Radiat. Prot. Dosim. 18(1):13-17.

Strand, T.; Stranden, E.; Rudjord, A.L. 1987. "External radiation doses to the Norwegian population from the Chernobyl fall-out." Radiat. Prot. Dosim. $20(4): 231-236$.

Streffer, C. 1987. "Hazards after prenatal exposure of man to radiation." In 27. annual conference of Vereinigung Deutscher Strahlenschutzaerzte e.V. Schuetz, J.; Boerner, W.; Messerschmidt, 0. (eds.), CoNF-8605338, Thieme, Stuttgart, Germany, F.R.

Stscherbak, J. 1988. Protocols of a catastrophe. Athenaeum Verl., Frankfurt, Germany, F.R.

Sumner, D. 1987. Radiation risks: an evaluation. Tarragon Press, Glasgow, Scotland.

Suter, A. 1986. "Safety following Chernobyl." Tech. Rundsch. 78(51):28-37.

Suzuki, Y.; Fujii, N.; Wariishi, M.; Hashimoto, T.; Nishiyama, K. 1986.

"Determination of $I-131$, released by accident at the Soviet Chernobyl Nuclear Plant, in air born dust and rainwater in Tokushima." Shikoku Igaku Zasshi $42(5-6): 131-134$.

Suzuki, Y.; Fujii, N.; Wariishi, M.; Hashimoto, T.; Nishiyama, K.; Sato, K. 1986. "Determination of TI, released by accident at the Soviet Chernobyl Nuclear Plant, in air born dust and rainwater in Tokushima." Shikoku Igaku Zasshi $42(5-6): 131-134$.

Szabo, A.S. 1987. "Did the radioactive contanination in Hungary due to the disaster at the Chernobyl nuclear power station have a biopositive effect on plants?" J. Radioanal. Nucl. Chem. 119(6):503-511.

Taira, H.; Uema, H. 1987. "Chernobyl accidents observed on Ryukyu Islands." Ryukyu Daigaku Rigakubu Kiyo 44:87-100.

Takano, M.; Shindo, R.; Yamashita, K.; Sawa, K. 1987. Analysis of space-time core dynamics on reactor accident at Chernobyl. Japan Atomic Energy Research Inst., Tokyo, Japan.

Tanguy, P. 1986. "Safety of French PWR nuclear power plants." In SVA information meeting on safety of nuclear power plants in the light of TMI and Chernobyl. Schweizerische Vereinigung fuer Atomenergie, Bern, Switzerland. 
Tanguy, P. 1987. "Operational safety of nuclear power plants." Energy Explor. Exploit. 5(5-6):453-472.

Tanguy, P. 1988. "Three decades of nuclear safety." IAEA Bul1. 30(2):51-57.

Tanguy, P. 1987. "Safety experience on EDF's PWRs." Nucl. Eng. Des. $103(1): 33-42$.

Tanguy, P. 1986. "First lessons from Chernobyl in Western Europe and France." Nucl. Eur. 6(11):19-22.

Tateno, Y. 1987. "Radiological aspects of the accident at the Chernobyl Nuclear Power Plant." Nippon Igaku Hoshasen Gakkai Zasshi 47(11):1387-1394.

Tato, L.; Zamboni, G.; Micciolo, R.; Avanzini, S. 1987. "Chernobyl and hypothyroidism." Lancet $1(8543): 1206$.

Tauxe, S.N.; Dimick, A.R. 1986. "Emergency room preparation for injuries caused by radioactive materials." In International conference on non-military radiation emergencies. DOE/ER/60525-1, Univ. of Pittsburgh School of

Medicine, Pittsburgh, PA, U.S.A.

Taylor, 0. 1988. "Nuclear industry in Britain - the long-term view." Nucl. Eur. 8(5):15-16.

Taylor, J.J. 1987. United States of America. Jones, P.M.S. (ed.), John Wiley and Sons Inc., Chichester, U.K.

Teherani, D.K. 1988. "Oetermination of $\mathrm{Cs}-137$ and $\mathrm{Cs}-134$ radioisotopes in various mushrooms from Austria one year after the Chernobyl incident." $\mathrm{J}$. Radioanal. Nucl. Chem. 126(6):401-406.

Teherani, D.K. 1987. "Oetermination of I-131, Cs-134, Cs-137 in grass and cheese after Chernobyl accident in Austria." J. Radioanal. Nucl. Chem. $118(6): 409-414$.

Teherani, D.K. 1987. "Accumulation of TRu, TXCs and TUCs in fruitbodies of various mushrooms from Austria after the Chernobyl incident." J. Radioanal. Nucl. Chem. 117(2):69-74.

Tennessee Valley Authority. 1986. Annual radiological environmental operating report, Sequoyah Nuclear Plant, 1986. Tennessee Valley Authority, Chattanooga, TN, U.S.A.

Tennessee Valley Authority. 1986. Environmental radioactivity levels, Browns Ferry Nuclear PIant: Annual report, 1986. Tennessee Valley Authority, Chattanooga, TN, U.S.A.

Tennessee Valley Authority. 1986. Annual radiological environmental monitoring report, Watts Bar Nuclear Plant, 1986. Tennessee Valley Authority, Chattanooga, TN, U.S.A. 
Teuchert, E.; Haas, K.A.; Scherer, W.; Singh, J. 1987. "Computer simulation of the initiation of the Chernobyl accident." ATW, Atormirtsch., Atomtech. $32(2): 86-89$.

Theenhaus, R.; Hille, R.; Heinemann, K. 1987. "Radiation exposure in the Federal Repubiic of Germany after the Chernobyl reactor accident. Comparison with calculation models for the vicinity of nuclear facilities. " ATW, Atomwirtsch., Atomtech. 32(7):365-369.

Theenhaus, R.; Wolters, J. 1987. "Reactor safety research and safety technology. Part. 2. HTR safety research and safety technique." In AGF congress on Chernobyl and the future of energy supply in the Federal Republic of Germany. Kernforschungsanlage Juelich G.m.b.H., Germany, F.R.

Thies, J. 1986. "Consequences of Chernobyl. A chance for East-West relations. "Eur. Arch. 41(19):551-560.

Thiessen, J.W. 1986. "Public health risks of nuclear emergencies." In International conference on non-military radiation emergencies. DOE/ER/60525-1, Department of Energy, Washington, D.C., U.S.A.

Thoma, F.; Urban, M.; Kaske, K. 1986. "Dropping nuclear power altogether will remove us from the world of industrialized countries. West Germany without nuclear power - is it a realistic perspective. SZ talks with Karlheinz Kaske, chairman of the board of Siemens AG." Sueddtsch. Ztg. 42(137):12.

Thomas, A.J.; Martin, J.M. 1986. "First assessment of Chernobyl radioactive plumes over Paris." Nature 321(6073):817-819.

Thomas, S. 1986. "Can international safety overcome national prejudice?" Financ. Times Energy Econ. 60:2-5.

Thompson, G. 1986. "What happened at Reactor Four?" Bull. At. Sci. $43(1): 26-31$.

Thompson, M. 1988. Lines of latitude: people's detente, East and West. Mackay, L.: Thompson, M. (eds.), Pluto Press, London, U.K.

Thomson, J.R. 1987. Engineering safety assessment. An introduction. Longman Scientific and Technical, Harlow, U.K.

Thomson, J.R. 1986. "Sample calculations of risk from Chernobyl fall-out in the UK." Nuc]. Eng. 27(5):151-152.

Tianshan, R.; Shurong, Z.; Rongling C.; et a1. 1987. "Gamma spectrometric analyses of environmental radioactive contamination following Chernobyl accident." Zhonghua Fangshe Yixue Yu Fanghu Zazhi 7(Suppl.):12-19.

Tilkorn, H.; Drepper, H. 1987. "Surgical treatment of delayed radiation effects in the skin and its indication." In 27. annual conference of Vereinigung Deutscher Strahlenschutzaerzte e.V. Schuetz, J.; Boerner, W.; Messerschmidt, 0. (eds.), CONF-8605338, Thieme, Stuttgart, Germany, F.R. 
Til1, C.E. 1987. "The integral fast reactor." J. Inst. Nucl. Mater. Manage. $16: 19-23$.

Tobias, A. 1987. Inventory predictions for Cs-134 in irradiated fuel. Central Electricity Generating Board, Berkeley, U.X.

Tobler, L.; Bajo, S.; Wyttenbach, A. 1988. "Deposition of Cs-134,137 from Chernobyl fallout on Norway spruce and forest soil and its incorporation into spruce twigs." J. Environ. Radioact. 6(3):225-245.

Toffer, H.; Twitche1l, R.W. 1987. "Dynamic analysis of the Chernobyl accident." Trans. Am. Nucl. Soc. 55:411-412.

Togawa, 0.; Homma, T.; Iijima, T.; Midorikawa, Y. 1988. Dose estimates in Japan following the Chernobyl reactor accident. JAERI-M-88-019, Japan Atomic Energy Research Inst., Tokyo, Japan.

Tognola, F. 1986. "Swiss electrical power industry: energy policy problems and prospects." Electro-Rev. 78(23):15-18.

Tokarenko, V.P. 1984. "Organizing and carrying out mounting operations at the Chernobylsk-4 power unit." Energ. Stroit. 12:6-7.

Tollefson, D.A.; Toffer, H.: Mohr, C.L. 1987. "Recent measurements supporting $N$ reactor graphite stack stored energy analysis." Trans. Am. Nucl. Soc. $54: 224-225$.

Tong, L.S. 1987. "Technical note: Two important issues in reactor assessment." Nucl. Saf. 28(3):331-333.

Torres, J. 1986. "The development and current activities of the DOE IandE Program." Nucl. Mater. Manage. 15:446-449.

Tovedal, H.; LaBrecque, J.J.; Schelenz, R.; Perkins, R.W. 1987. "Analyses of grass samples in Sweden after the Chernobyl accident." In Consultants' meeting on the determination of radionuclides in grass ecosystem samples. Studsvik Energiteknik AB., Nykoeping, Sweden.

Tracy, B.L. 1986. "Impact of the Chernobyl Accident on Canada" In Special Session on the Chernobyl Accident, Nuclear Energy Agency/0ECD. Environmental Radiation Hazards Division, Dept. of National Health and Welfare, Ottawa.

Trades Union Congress. 1986. Nuclear energy: work to be done. A report of the General Council to the 1986 TUC Congress. Trades Union Congress, London, U.K.

Trades Union Congress, 1987. Nuclear energy: General Council report. Trades Union Congress, London, U.K.

Traube, K. 1986. After the super MCA. Chernobyl and the consequences. Rowohlt Taschenbuch Verl., Reinbek, Germany, F.R. 
Trenk]er, H. 1986. "News from the American electric power industry. Upward tendency in US electricity demand. "Energiewirtsch. Tagesfragen $36(10): 769-773$.

Trenta, G. 1987. "Risk projection and epidemiological survey following the Chernobyl accident. What statistics suggest." Acqua Aria 10:1251-1256.

Troyanovskii, B.M. 1986. "Reports on power engineering and power machine construction presented at the 27 th Congress of the Communist Party of the USSR." Teploenergetika 4:2-6.

Trumpington, B. 1987. "Food Protection (Emergency Prohibitions) (No. 4) Order 1987; Food Protection (Emergency Prohibitions) (England) Order 1987; Food Protection (Emergency Prohibitions) (Wales) (No. 5) Order 1987; Food Protection (Emergency Prohibitions) (No. 3) Or." Hansard, House Lords. Off. Rep. $490(35): 65-72$.

Tschiersch, J.; Georgi, B. 1987. "Chernobyl fallout size distribution in urban areas." J. Aerosol Sci. 18(6):689-692.

Tschirf, E. 1986. "Chernobyl reactor accident and its radiological implications for Austria." In Austrian Physical Society annual convention. Atominstitut der Oesterreichischen Universitaeten, Vienna, Austria.

Tsenenko, I.K.; Aleksandrov, N.E. 1984. "Application of sectional-monolithic structures during the second phase of the Chernobylsk NPP construction." Energ. Stroit. 11:6-8.

Tsuchihashi, K.; Akino, F. 1987. "Analysis of reactivity coefficients of Chernobyl reactor by cell calculation." J. Nucl. Sci. Technol. $24(12): 1055-1065$.

Tubiana, M. 1986. "Chernobyl accident and population health: which lessons?" Rev. Gen. Nucl. 3:279-281.

Tucker, A.; Bowlt, C. 1986. "Thyroid radiation dose in Britain arising from the Chernobyl accident; and reply." Lancet 2(8517):1220-1221.

Tulenko, J.S.; Crane, C.; Carlton, R.E. 1987. "Advanced semiautonomous robotic system for hazardous response work at nuclear power stations." Irans. Am. Nucl. Soc. 55:677.

Tuschl, H.; Kovac, R.: Topaloglou, A. 1988. DNA, sister chromatid-exchanges and immunological parameters in $\mathrm{Rn}$ - and occupational radiation exposure. OEFZS-4450, Oesterreichisches Forschungszentrum Seibersdorf G.m.b.H., Vienna, Austria.

Treten, U. 1987. Validation of techniques for simulating long range dispersa? and deposition of atmospheric pollutants based upon measurements after the Chernobyl accident. Transfrontier atmospheric models (TRANSAM). Institute for Energy Technology, Kjeller, Norway. 
Tyror, J.G.; Garlick, A.R. 1988. "Safety goals for nuclear power plants." In International approach to nuclear safety seminar. Ballard, G.M. (ed.). CONF-8806174, Elsevier Applied Science, London, U.K.

UNSCEAR, 1988. Ionizing Radiation: Sources and Biological Effects United Nations Scientific Committee on the Effects of Atomic Radiation, New York.

USDOE. 1986. Design review of the $N$ Reactor. USDOE Assistant Secretary for Environment, Safety, and Health, Washington, D.C., U.S.A.

USDOE. 1986. Report of the US Department of Energy's team analyses of the Chernobyl-4 Atomic Energy Station accident sequence. USDOE Assistant Secretary for Nuc lear Energy, Washington, D.C., U.S.A.

USDOE. 1986. Interim Status Report - U.S. Team Analys is of the Chernobyl-4 Accident U.S. Department of Energy, Washington, D.C.

USDOE. 1987. Report on the accident at the Chernobyl Nuclear Power Station. USDOE, Washington, D.C., U.S.A.

USDOE Interlaboratory Task Group on Health \& Environmental Aspects of the Soviet Nuclear Accident. 1987. Health and Environmental Consequences of the Chernobyl Nuclear Power Plant ACcident, DOE-ER-0332, National Technical Information Service, Springfield, VA, U.S.A.

USSR. 1986. "The ACcident at the Chernobyl Nuclear Power Plant and Its Consequences" In International Atomic Energy Agency Experts' Meeting. USSR State Committee on the Utilization of Atomic Energy.

USSR. 1987. Analysis of the Radiological Consequences of the Accident at the Chernobyl Nuclear Power Plant for the Population of the European Regions of the USSR Ministry of Health of the USSR, Moscow.

Uchida, H. 1987. "Safety policy for nuclear power development." In International symposium on nuclear safety. CONF-871291, Nuclear Safety Commission, Tokyo, Japan.

Uchiyama, M.; Kobayashi, S. 1988. "Increased body burden of radiocesium in four cases of Japanese after the Chernobyl reactor accident." J. Nucl. Sci. Technol. 25(4):413-416.

Uibopuu, H.J. 1986. "Chernobyl in the light of Soviet law." Recht 0st. West $30(5): 269-278$.

Umezaki, N.; Ogura, R.; Ohtake, H.; Morita, S.; Takashima, Y.; Momoshima, N.; Okumura, Y.; et al. 1987. "Radioactivity detected from a tourist who was in Europe during the accident of Chernobyl Atomic Power Plant." Kurume Igakkai Zasshi $50(3-4): 278-283$. 
Underwood, B.Y.; Cooper, P.J.; Nixon, W. 1988. "Modelling the consequences of reactor accidents." In International approach to nuclear safety seminar. Ballard, G.M. (ed.), CONF-8806174, Elsevier Applied Science, London, U.K.

Upton, J.W. Jr. 1987. Assessment of the impacts of transferring certain nuclear reactor technologies to the Soviet Union and Eastern Europe. Pacific Northwest Lab., Richland, WA, U.S.A.

Uranium Inst. 1986. Understanding Chernobyl. Uranium Institute, London, U.K.

Uranium Inst. 1986. Uranium market 1986-2000. Uranium Institute, London, U.K.

Uranium Inst. 1987. "Uranium and nuclear energy: 1986." In 11. annual symposium of the Uranium Institute. CONF-860915, Uranium Institute, London, U.K.

Urban, M. 1986. "Energy policy of the future - a resume. The pros and cons of nuclear power." Sueddtsch. Ztg. 42(149):15.

Urbanek, A. 1987. "Federal Government delays use of renewable energy." Sonnenenergie Waermepumpe 12(6):4-9.

Uschakow, A. 1986. "Chernobyl and Soviet Iaw." Versicherungsrecht $37(29): 721-728$.

Uslu, I.; Fields, D.E.; Yalcintas, M.G. 1988. TRANF000: Radionuclide transport via terrestrial food chain. ORNL/TM-10782, Oak Ridge National Lab., Oak Ridge, TN, U.S.A.

Vaas, L.H. 1986. Radioactive deposition in the Netherlands caused by the reactor accident at Chernoby1. Document 5 . Rijksinstituut voor Volksgezondheid en Milieuhygiene, Bilthoven, Netherlands.

Vajda, G. 1986. "Chernobyl lesson." Magy. Tud. 31(12):970-977.

Van Dam, H. 1986. "Silver from Chernobyl." Nature 324(6094):216.

Van Den Eshof, A. 1986. Measures taken as a result of the nuclear reactor accident at Chernobyl. Document 9. Ministerie van Welzijn, Leidchendam, Netherlands.

Van Den Wall Bake, D.A.; Geut, L.; Zorn, G.W.H. 1986. Evaluation investigation 'Chernobyl'. Report on the action taken by the Dutch governinent on account of the nuclear reactor accident at Chernobyl, USSR. Berenschot B.V., Utrecht, Netherlands.

Van Der Veen, J.; Van Der Wijk, A.; Mook, W.G.; De Meijer, R.J. 1986. "Core fraginents in Chernobyl fallout." Nature 323(6087):399-400. 
Van Der Wijk, A. 1987. Radiometric dating by alpha spectrometry on uranium series nuclides. INIS-mf-11199, Rijksuniversiteit Groningen, Netherlands.

Van Egmond, N.D. 1987. "Estimation on models of concentrations and deposits of radioactive materials in Europe in consequence of the Chernobyl accident. Chapter 6." In Chernobyl - environment and health aspects. Van Loon, A.J. (ed.), KIVI-Kerntechniek, Arnhem, Netherlands.

Van Egmond, N.D. and Wirth, E. 1986. "WHO Working Group on Assessment of Radiation Dose Commitment in Europe Due to the Chernobyl Accident" In Biltnorem. World Health Organization, Regional Office for Europe, Copenhagen.

Van Heerden, A. 1986. "Could a 'Chernobyl' nuclear disaster happen here?" Electricity Supply Commission 40(3):92-95, 97.

Van Iddekinge, F.W. 1986. "Progress summary of the Chernobyl accident. Lecture." In Chernobyl = environment and health aspects. IAEA, Vienna, Austria.

Van Iddekinge, F.W. 1987. "Design of the RBMK-1000 in Chernobyl. Chapter 1." In Chernobyl - report of the Outch delegation. Van Loon, A.J. (ed.), KIVI-Kerntechniek, Arnhem, Netherlands.

Van Loon, A.J. (ed.). 1987. Chernobyl accident: causes, effects and measures. KIVI-Kerntechniek, Arnhem, Netherlands.

Van Middlesworth, L. 1987. Studies in iodine metabolism: Monitoring of animal thyroids: Final progress report, April 1983 through March 1987. Tennessee Univ., Memphis, TN, U.S.A.

Van Veen, R.; Van Oirschot, M.C.M.; Uunk, E.J.B.; Van Baardwijk, F.A.N. 1986. Surface water, air suspension and purgation mud. Document 8.

Rijkswaterstaat, Lelystad, Netherlands.

Van Voris, P.; Cowan, C.E.; Cataldo, D.A.; Wildung, R.E.; Shugart, H.H. 1988. "Modeling the dynamics of long-term cycling and storage of $\mathrm{Cs}-137$ in forested ecosystems." In SCOPE-ENUWAR workshop on the environmental consequences of

nuclear war. Pacific Northwest Lab., Richland, WA, U.S.A.

Varley, J. 1988. "Comecon plans still ambitions." Nucl. Eng. Int. $33(407): 31-36$.

Varley, J. 1988. "Report from Chernobyl (recovery operations)." Nucl. Eng. Int. $33(404): 18-22$.

Vekicj, B.; Ranogajec-Komor, M.; Korenika, Dzh; Dvornik, I.; Vrhovac, A.; Shojat, V. 1987. "Environmental gamma dose measurements in Croatia." In 14. Yugoslav symposium on radiation protection. Yugoslav Radiological Protection Association, Novi Sad, Yugoslavia. 
Verein Deutscher Ingenieure (VDI) - Gesellschaft Energietechnik. 1988. "Nuclear power, energy source of the future." In 4. annual meeting of the VDI-Gesellschaft Energietechnik: energy and engineering for our future. CONF-880281, VDI-Verl., Duesseldorf, Germany, F.R.

Versteeg, J. 1987. "Learning from operation experiences and technical troubles in nuclear power plants. Chapter 12." In How can the engineer minimize the risks of nuclear power plants?. Van Loon, A.J. (ed.), KIVI-Kerntechniek, Arnhem, Netherlands.

Versteegh, A.M. 1987. "What went wrong with unit four in Chernobyl. Chapter 2." In ChernobyI - report of the Dutch delegation. Van Loon, A.J. (ed.), KIVI-Kerntechnjek, Arnhem, Netherlands.

Vesseron, P. 1987. "Developments for emergency planning in France." In Conference on nuclear risks - reassessing the principles and practical after Chernobyl. IBC Technical Services Ltd., London, U.K.

Vester, F. 1986. "Radioactivity: A stocktaking of misconceptions and misunderstandings." In Meeting on after the Chernoby 7 accident: how safe is our food?. CONF-8606412, Stiftung Verbraucherinstitut, Berlin, Germany, F.R.

Vester, F. 1986. Striking a balance of abberations and confusion. Information, reports and arguments in view of the changed situation after the Chernoby! reactor accident. Heyne, Muenchen, Germany, F.R.

Vignon, D.; Kus, J.P. 1988. "Role of special procedures and related features in the french nuclear safety approach." In International approach to nuclear safety seminar. Ballard, G.M. (ed.), CONF-8806174, Elsevier Applied Science, London, U.K.

Villarreal, E. 1986. "Nuciear accidents." Nucleares 1(2):66-74.

Vintersved, I.; De Geer, L.E.; Bjurman, B.; Arntsing, R.; Jakobsson, S.; Mellander, H. 1987. "Early measurements of the Chernobyl fallout in Sweden." IEEE Trans. Nucl. Sci. NS-34(1):590-594.

Viragh, E. 1988. "Radiological consequences of the Chernobyl nuclear accident for Hungary." Kernenergie 31(6):258-262.

Virole, J. 1986. "Legal aspects of the Chernobyl nuclear accident with regard to compensation of the resulting damage outside the USSR and East European countries." Rass. Giurid. ENEL 3(3):597-612.

Vogl, J. 1987. "Conclusions from the consequences of the reactor accident of Chernobyl for Bavaria." Nuklearmediziner 10(5):393-394.

Vogl, J. 1986. "Information and recommendations for the general public, concerning the effects of the Chernobyl reactor accident in Bavaria." Gesund.-Ing. 107(5):264-265. 
Vogt, J. 1986. "What Chernobyl has brought us? Report of the seminar 'The Chernobyl reactor accident and its consequences', Neuherberg 1986." Dtsch. Aerzteb1. 83(30):2091-2098.

Voigt, G.; Henrichs, K.; Proehl, G.: Paretzke, H.G. 1986. Experimental determination of the transfer functions feed/beaf, feed/pork, feed/milk for $\mathrm{Cs}-137, \mathrm{Co}-60, \mathrm{Mu}-54, \mathrm{Na}-22, \mathrm{I}-131$, and Tc-95m. GSF-2/87, Geselischaft fuer Strahlen-und Umweltforschung G.m.b.H. Muenchen, Neuherberg, Germany, F.R.

Volchok, H.L.; Chieco, N. (eds.). 1986. Compendium of the Environmental Measurements Laboratory's research projects related to the Chernobyl nuclear accident. USDOE Environmental Measurements Lab., New York, NY, U.S.A.

Volod'ko, Yu.I.; Garusov, Yu.V.; Egorov, 0.K.; Lyutov, M.A.; Postnikov, V.V.; Rybakov, Yu.V. 1987. "Testing neutron Compton emission detectors with emitters containing hafnium in the RBMK-1000 reactor." At. Energ. $62(6): 407-409$.

Von Bennigsen-Foerder, R. 1986. "Energy policy amid the conflict of the debate on acceptance." Elektrizitaetswirtschaft 85(20):763-766.

Von Bennigsen-Foerder, R. 1986. "Future energy concept. Its acceptance against the background of the discussion about a nuclear power phase-out." Energiewirtsch. Tages fragen 36(11):836-841.

Von Busekist, 0. 1987. "Liability problems between contracting states of the Paris and the Vienna nuclear liability conventions." In AIDN/INLA regional conference on peaceful uses of nuclear energy and state frontiers in Central Europe. Pelzer, N. (ed.), Nomos Verlagsges, Baden-Baden, Germany, F.R.

Von Gunten, H.R.; Waber, U.; Krahenbuhl, U. 1987. "The reactor accident at Chernobyl: A possibility to test colloid-controlled transport of radionuclides." In 193. national meeting of the American Chemical Society. American Chemical Society, washington, D.C., U.S.A.

Von Hippel, F.; Cochran, T.B. 1986. "Estimating long-term health effects." Bul1. At. Sci. 43(1):18-24.

Von Dertzen, H.J. 1987. "Viewing radiation protection in the framework of general environmental protection." In 27. annual conference of Vereinigung Deutscher Strahlenschutzaerzte e.V. Schuetz, J.; Boerner, W.; Messerschmidt, 0. (eds.), CoNF-8605338, Thieme, Stuttgart, Germany, F.R.

Von Preuschen-Liebenstein, R. 1986. "30th IAEA general conference. International cooperation intensified in the light of Chernobyl." ATW, Atomwirtsch., Atomtech. 31(12):603-605.

Von Websky, M. 1987. "Standards and dose limits in reactor accidents." In AIDN/INLA regional conference on peaceful uses of nuclear energy and state frontiers in Central Europe. Pelzer, N. (ed.), Nomos Verlagsges, Baden-Baden, Germany, F.R. 
Vonach, H.; Steger, F. 1987. "Experimental study of caesium-137 incorporation in man." Radiat. Prot. Dosim. 19(4):253-256.

Voss, A.; Friedrich, R.; Kaltschmitt, M. 1986. "Consequences of a nuclear phase-out. A critical analys is of available phase-out studies." Energiewirtsch. Tagesfragen 36(12):925-933.

Vossebrecker, H. 1987. Assessment of special safety-related features of the SNR-300 against the background of the Chernobyl accident. Internationale Atomreaktorbau G.m.b.H. (INTERATOM), GTadbach, Germany, F.R.

Vuorinen, A.; Eurola, A.T.; Virolainen, R.K. 1988. "Deteministic versus probabilistic based safety and licensing decisions with particular emphasis on severe low probability events." In International conference on nuclear power performance and safety. CONF-8709263, IAEA, Vienna, Austria.

WHO. 1986. Summary Review of Measurement Results Relevant for Dose Assessment, Updated Revision No. 7 World Health Organization, Regional office for Europe, Copenhagen.

WHO. 1986. Updated Background Information on the Nuclear Reactor Accident in Chernobyl, USSR World Health Organization, Regional Office for Europe, Copenhagen.

Waas, U. 1986. Nuclear energy - a vote for good sense. (4th Edition). Deutscher Instituts-Verl., Koeln, Germany, F.R.

Waber, U.; Kraehenbueh1, U.; Von Gunten, H.R. 1987. "Impact of the Chernobyl accident on a river/groundwater aquifer." Radiochim. Acta $41(4): 191-198$.

Waddington, J.I. 1986. "Radiation impact of Chernobyl in Western Europe." Nucl. Eur. 6(11):11-12.

Wade, B. 1988. Radiological Protection Research annual report 1988. AERE-R-13204, UKAEA Harwe11 Lab., U.K.

Wagner, C. 1987. "Nuclear energy after Chernoby1." In Winter meeting of the German Atomic Forum: nuclear fuel for the Federal Republic of Germany. CONF-870122, Deutsches Atomforum e.V., Bonn, Germany, F.R.

Wagner, H. 1987. "No backing out of nuclear energy through statutory interpretation." Neue Jurist. Wochenschr. 40(8):411-418.

Wagner, H. 1987. "Backing out of nuclear energy by administrative act. A short note on the revocation of reactor operating permits." Oeff. Verwalt. $40(12): 524-533$.

Wagner, S.R. 1987. "New developments in dose notions and measuring methods for radiation." In 27. annual conference of Vereinigung Deutscher Strahlenschutzaerzte e.V. Schuetz, J.; Boerner, W.; Messerschmidt, 0. (eds.), CONF-8605338, Thieme, Stuttgart, Germany, F.R. 
Wakabayashi, H. 1987. "Development status of PIUS/ISER - a inherently safe reactor for the international use." In International nuclear engineering symposium on the development and use of small and medium size power reactors in the next generation. CONF-8611129, Tokai Univ., General Research organization, Tokyo, Japan.

Wakabayashi, T.; Hayamizu, Y. 1987. "Accident of Chernobyl's nuclear power plant. Technical evaluation of improvement measures announced by Soviet Union." Genshiryoku Kogyo 33(2):49-58.

Wakabayashi, T.; Hayamizu, Y.; Kitahara, T. 1988. "Analys is of the Chernoby1 reactor accident. Part. 2. An examination of the improvement measures concerning the accident of the Chernobyl power plant." Nucl. Eng. Des. $106(2): 163-178$.

Wakabayashi, T.; Mochizuki, H.; Midorikawa, H.; Hayamizu, Y.; Kitahara, T. 1987. "Analysis of the Chernobyl reactor accident. Part. 1. Nuclear and thermal hydraulic characteristics and follow-up calculation of the accident." Nucl. Eng. Des. 103(2):151-164.

Wakabayashi, T.; Mochizuki, H.; Midorikawa, H.; Hayamizu, Y.; Kitahara, T. 1986. "Analysis of Chernobyl reactor accident. Nuclear and thermal hydraulic-characteristics and follow-up calculation of accident. "Nippon Genshiryoku Gakkaishi 28(12):1153-1164.

Walinder, G. 1986. "Radiation and cancer in Sweden after the Chernobyl accident." In Conference on radiation and health hazards: Chernobyl in perspective. Sveriges Lantbruksuniversitet, Uppsala, Sweden.

Walker, P.; Bruce, M.; Orme, S. 1987. "Nuclear power and Sizewell debate." Hansard, House Commons Off. Rep. 116(105):81-124.

Walker, P.; Dalyell, T.; Orme, S. 1987. "Sizewell Nuclear Power Station." Hansard, House Lords. Off. Rep. $111(58): 25-112$.

Walker, P.: Orme, S.; Hannam, J. 1987. "Sizewell B Nuclear Power Station." Hansard, House Lords. Off. Rep. 112(71):475-490.

Wallmann, W. 1986. "Irresponsible from the ethical point of view. We can get out of nuclear power as soon as there is something better." Zeit $41(39): 33-34$.

Walmod-Larsen, 0.; Ryder, H.P. 1988. "Denmark's planned nationwide warning system for fallout from nuclear accidents." Nucl. Eur. 8(3-4):27.

Walske, C. 1986. "National report: United States. Lessons of Chernobyl." IAEA Bul1. 28(3):38-39.

Walters, B. 1988. "Chernobyl derived activity in sheep: variation within a single flock and with time." J. Environ. Radioact. $7(2): 99-106$. 
Walters, B.; Mondon, K. 1987. "Dietary studies - assessment of radionuclide intake by population groups in the UK." In Conference on health effects of low dose ionizing radiation: recent advances and their applications. CONF-870534, Thomas Telford, London, U.K.

Wambersie, A.; Scalliet, P. 1986. "Consequences of the jonizing radiations on men and environment." Rev. Quest. Scj. 157(4):445-474.

Warman, E.A. 1987. "Soviet and Far-Field Radiation Measurements and an Inferred Source Term from Chernobyl" In NY Chapter Health Physics Society Symposium on the Effects of the Nuclear Reactor Accident at Chernobyl. Stone \& Webster Engineering Corp., Boston, MĀ.

Warner, F. 1987. "Chernobyi - ethical and environmental considerations." IEE Proc., Part A 134(10):834-840.

Warnock, M. 1986. "Future since Chernoby1." Times Lit. Suppl. 4359:1155-1156.

Warrikoff, A. 1987. "Future energy supplies - requirements of an acceptable energy policy." In Meeting on ways out of the environmental crisis. Irrgang, B.: Klawitter, J.i Seif, K.P. (eds.), CoNF-8510494, Schweitzer, Frankfurt am Main, Germany, F.R.

Wasastjerna, F. 1987. "Group structures for RBMK cell calculations." Trans. Am. Nucl. Soc. $54: 380-382$.

Watari, K.; Imai, K.; Ohmomo, Y.; Muramatsu, Y.; Nishimura, Y.; et al. 1988. "Simultaneous adsorption of $\mathrm{Cs}-137$ and $\mathrm{I}-131$ from water and milk on 'meta] ferrocyanide-anion exchange resin'." J. Nucl. Sci. Technol. 25(5):495-499.

Waters, T.L. 1988. "Human reliability analys is methods." In International approach to nuclear safety seminar. Ballard, G.M. (ed.), Conf-8806174, Elsevier Applied Science, London, U.K.

Watson, W.S. 1987. "Human radiocesium levels in Scotland." In 21. annual conference on trace substances in environmental health. Hemphill, D.D. (ed.), CONF-8705217, University of Missouri, Columbia, M0, U.S.A.

Watson, W.S. 1986. "Human TUCS/TXCs levels in Scotland after Chernoby1." Nature $323(6091): 763-764$.

Webb, G.A.M. 1987. "More Chernobyl data from the USSR." Radiol. Prot. Bull. $87: 4-5$.

Webb, G.A.M.; Simmonds, J.R.; Wilkins, B.T. 1986. "Radiation levels in Eastern Europe." Nature 321(6073):821-822.

Webb, R.E. 1986. "Chernobyl mortality." Ecologist 16(6):279.

Webb, R.E. 1986. "Chernobyl: what could have happened?" Ecologist $16(4-5): 167-168$. 
Webb, R.E. 1986. "Health consequences of Chernobyl." Ecologist $16(4-5): 169-170$.

Webb, R.E. 1986. "Western reactors: how they compare with Chernobyl." Ecologist 16(4-5):164-167.

Weber, M. 1986. Institute for Nuclear Chemistry, University of Mainz. Annual report 1985. Mainz Univ., Germany, F.R.

Weber, M. (ed.). 1987. Institute for Nuclear Chemistry of the University of Mainz. Annual report 1986. Mainz Univ., Germany, F.R.

Websky, M. v. 1987. "State of discussions on the draft amendment to the Radiation Protection Ordinance." In 27. annual conference of Vereinigung Deutscher Strahlenschutzaerzte e.V. Schuetz, J.; Boerner, $W . ;$ Messerschmidt, 0. (eds.), CoNF-8605338, Thieme, Stuttgart, Germany, F.R.

Webster, D. 1987. "Chernobyl's fallout." New Sci. 114(1560):69.

Webster, D. 1986. "How ministers misled Britain about Chernoby1." New Sci. $112(1529): 43-46$.

Wegrampf, G. 1986. "Measures taken by the authorities in the Bavarian Capital Munich after the Chernobyl reactor accident." In Meeting on after the Chernobyl accident: how safe is our food?. CoNF-8606412, Stiftung Verbraucherinstitut, Berlin, Germany, F.R.

Weinberg, A.M. 1986. "Nuclear power advocate reflects on chernoby1." Bull. At. Sci. $43(1): 57-60$.

Weinberg, A.M. 1986. "Reflections on Chernoby1." J. Inst. Nucl. Mater. Manage. 15(1):18-21.

Weinberg, B. 1987. "Laguna Verde: the nuclear debate in Mexico." Ecologist $17(6): 226-229$.

Weinstein, N. 1986. "Swedish electricity policy after Chernobyl: the 1980 nuclear referendum revisited." Search 17(7-9):168-169.

Weish, P.; Gruber, E. 1986. Radioactivity and environment. (3rd Edition). Fischer, Stuttgart, Germany, F.R.

Weiss, W.; Sittkus, A.; Sartorius, H.; Stockburger, H. 1987. "Chernobyl - a review of events. The reactor accident of Chernobyl and the resulting environmental contamination in West Germany." Phys. Bu11. 43(5):125-130.

Weiss, W.; Stockburger, H.; Sartorius, H.; Rath, H.K. 1987. "Do higher radioactivity leveis in the air lead to a measurable change of the level of 'conventional' trace materials?" In Forum on impact of radioactive materials on the atmospheric pollutant inventory and on the radioactivity uptake by plants. Bundesamt fuer Zivilschutz, Freiburg, Germany, F.R. 
Wendling, K. 1986. "Chernobyl. Report of the Federal Minister for the Environment, Protection of Nature and Reactor Safety on the reactor accident. Report dated June 18, 1986." Energiewirtsch. Tagesfragen 36(9):733-738.

Wenger, H. 1988. "Swiss operating experience: availability and post-Chernobyl upgrading." Nucl. Eur. 8(6-7):39-40.

Wernli, C. 1987. "Radiological consequences of the Chernobyl accident for Switzerland." Radiat. Prot. Dosim. 19(4):235-238.

Westemark, T. 1986. "Why do we have such different opinions?" In Conference on radiation and health hazards: Chernobyl in perspective. Royal Inst. of Tech., Stockholm, Sweden.

Westin, J.B. 1987. "Ionizing radiation from tobacco." J. Am. Med. Assoc. $257(16): 2169$.

Wheeler, D.A. 1988. "Atmospheric dispersal and deposition of radioactive material from Chernobyl." Atmos. Environ. 22(5):853-863.

Wheeler, D.A. 1987. "Radioactivity in rainwater following the Chernobyl accident." Environmental ist 7(1):31-34.

Whipple, C.; Starr, C. 1988. Nuclear power safety goals in light of the Chernobyl accident. Silver, E.G. (ed.), Electric Power Research Institute, Palo Alto, CA, U.S.A.

White, I.F. 1987. "Nuclear safety after Chernobyl." Radiol. Prot. Bull. $84: 21-23$.

Whitehead, N.E.; Ballestra, S.; Holm, E.; Huynh-Ngoc, L. 1988. "Chernobyl radionuclides in shellfish." J. Environ. Radioact. 7(2):107-121.

Whitehead, N.E.; Ballestra, S.; Holm, E.; Walton, A. 1988. "Air radionuclide patterns observed at Monaco from the Chernobyl accident." J. Environ. Radioact. $7(3): 249-264$.

Whitfield, D. 1987. "Minimising human error by system design." In Conference on nuclear risks - reassessing the principles and practical after Chernobyl. IBC Technical Services Ltd., London, U.K.

Wiechen, A. 1987. Radioactive contamination of milk and milk products due to the Chernobyl reactor accident. Auswertungs-und Informationsdienst fuer Ernaehrung, Godesberg, AID.

Wigley, D.; Best, K.; Marek, J.; Livsey, R.; Corrie, J.; Thomas, D.E.; Meyer, A.; Robinson, M. 1986. "Sheep: radioactivity after Chernobyl." Hansard, House Commons Off. Rep. 102(158):734-754.

Wigley, D.; Boothroyd, B.; Grist, I. 1987. "Food protection." Hansard, House Commons off. Rep. 122(45):876-895. 
Wild, W. 1987. "Nuclear controversy." ATW, Atomwirtsch., Atomtech. $32(4): 193-197$.

Wilhelmova, L.; Tomasek, M.; Rybacek, K. 1987. "Aerosol and gaseous radioiodine concentration in the air of Prague after the Chernobyl accident." J. Radioanal. Nucl. Chem. 117(5):305-309.

Wilken, R.D.; Diehl, R. 1987. "Strontium-90 in environmental samples from Northern Germany before and after the Chernobyl accident." Radiochim. Acta $41(4): 157-162$.

Wilkie, T.; Milne, R. 1986. "World's worst nuclear disaster: what went wrong (Chernobyl)?" New Sci. 110(1506):17-19.

Wilkie, T.; Milne, R. 1986. "Chernobyl: sorting fact from fiction." New Sci. $110(1507): 17-19$.

Wilkie, T.; Taylor, P. 1986. "Unanswered question of Chernobyl; Chernobyl: the long-term consequences." New Sci. 110(1508):23-25.

Wilkins, B.T. 1987. "Some experimental studies of environmental transfer." Radiol. Prot. Bu11. 80:5-8.

Wilkins, B.T.; Bradley, E.J.; Dodd, N.J. 1987. "Effects of culinary preparation on radionuclide levels in vegetable foodstuffs." Radiat. Prot. Dosim. 20(3):187-190.

Wilkins, B.T.; Clark, M.J. 1988. "Radiation and radionuclide monitoring during emergencies." Nucl. Eur. 8(3-4):26.

Wilkinson, J. 1987. "Media treatment of nuclear risks." In Conference on nuclear risks - reassessing the principles and practical after chernobyl. IBC Technical Services Ltd., London, U.K.

Wilkinson, M. 1987. "How safe is an AGR?" Atom 367:22-23.

Williams, S.L. 1986. "Profiles of America's leading renewable electricity developers." Alternative Sources Energy 83:32-33.

Wilson, L.G. 1986. Radioactivity - a layman's guide. British Food Manufacturing Industries Research Association, Leatherhead, U.K.

Wilson, L.G.; Sutton, P.M.; Bottomley, R.C.; Sisk, C.H. 1988. "Transfer of radioactive contamination from milk to commercial dairy products." $\mathrm{J}$. Soc. Dairy Technol. 41(1):10-13.

Wilson, R. 1987. "Visit to Chernobyl." Science 236:1636-1640.

Wilson, R. 1987. "Nuclear safety after Chernobyl." Environ. Sci. Technol. 21(11):1051-1052. 
Winder, A.E.; Stanitis, M.A.; Stoddard, A.M. 1988. "After Chernobyl--how US physicians respond to radioactive fallout." Public Health Rep. $103(2): 128-135$.

Winkelmann, I.; Endrulat, H.J.; Fouasnon, S.; Gesewsky, P.; Haubelt, R.; Klopfer, P. 1986. Results of the activity measurements after the reactor accident in Chernobyl. Bundesgesundheitsamt, Neuherberg, Germany, F.R.

Winkelmann, I.; Klopfer, P.; Weimer, S.; Wolff, S. 1986. "Nuclide-specific measurements of soil contamination in Bavaria, and the relevant radiation exposure." Gesund.-Ing. 107(5):293-300.

Winter, C.J.; Nitsch, J. 1987. "Solar energy - its contribution to future energy supplies and particularly to the electricity supply of the Federal Republic of Germany." In AGF congress on Chernobyl and the future of energy supply in the Federal Republic of Germany. Deutsche Forschungs-und Versuchsanstalt fuer Luft-und Raumfahrt e.V. (DFVLR), Germany, F.R.

Winter, M.; Meyer, P.; Voelkle, H.; Narrog, J.; Kirchhoff, K. 1986. Radioactivity in the Federal Republic of Germany and in Switzerland after the Chernobyl reactor accident. Results of a measuring campaign by the Activity Group for Environmental Monitoring. Fachverband fuer Strahlenschutz e.V., KarTsruhe, Germany, F.R.

Wirth, E. 1987. Exposure to natural radiation from the earth's crust, atmosphere and outer space - some fundamental facts and figures. Hosemann, G.; Wirth, E. (eds.), INIS-mf-11696, Erlangen-Nuernberg Univ., Erlangen, Germany, F.R.

Wirth, E.: Van Egmond, N.D.; Suess, M.J. (eds.). 1987. "Assessment of radiation dose commitment in Europe due to the Chernobyl accident. Report on a WHO meeting, Bilthoven, 25-27 June 1986." In WHO meeting: assessment of radiation dose commitment in Europe due to the Chernobyl accident.

Bundesgesundheitsamt, Neuherberg, Germany, F.R.

Wirth, E.; Winkelmann, I. 1986. "After Chernobyl: How safe is our food? Contamination pathways air, soil, water." In Meeting on after the Chernobyl accident: how safe is our food?. CONF-8606412, Stiftung Verbraucherinstitut, Berlin, Germany, F.R.

Witkowski, R.; Koerner, H. 1987. "Has the increase of radiation burden after the Chernobyl accident influenced the conception rate and the fetal chromosomal anomalies?" 2. Kl in. Med. 42(24):2203-2204.

Wolters, J. 1987. "Past accidents with core degradation in thermal reactors. Causes, procedure and consequences." ATW, Atomwirtsch., Atomtech. $32(6): 285-293$.

Wolters, J.; Breitbach, G.; Kroeger, W. 1986. "Soviet LWGR type reactor (RBMK-1000). Discussion of the reactor design and first account of the accident scenario." ATW, Atomwirtsch., Atomtech. 31(6):286-289. 
World Health Organization. 1987. Chernobyl: health hazards from radiocesium following the Chernobyl nuclear accident. Report on a WHO (World Hea7th Organization) meeting held at Guenzburg, Federal Republic of Germany on 9-12 June 1987. World Health Organization, Copenhagen, Denmark.

World Heaith Organization. 1987. Nuclear accidents and epidemiology: reports on two meetings. Epidemiology related to the Chernobyl nuclear accident, and appropriate methodologies for studying possible long-term effects of radiation on individuals exposed in a nuclear accid. World Health Organization, Copenhagen, Denmark.

World Health Organization. 1986. Chernobyl reactor accident. Report of a consultation 6 May 1986 (Provisional). World Health Organization, Copenhagen, Denmark.

Wright, J.K. 1987. "Influence of the Sizewe11 B decision on nuclear power safety in the UK." In Conference on the future of nuclear power after Sizewell B. CONF-8709242, IBC Technical Services Ltd., London, U.K.

Wyman, V. 1988. "Reacting to Chernobyl." Engineer p. 24.

Yalcintas, M.G. 1987. "Effects of fallout from Chernobyl on neighboring countries." J. Tenn. Acad. Sci. 62(2):37.

Yoshida, K.; Tanabe, F.; Hirano, M.: Kohsaka, A. 1986. "Analyses of power excursion event in Chernobyl accident with RETRAN code." J. Nucl. Sci. Technol. 23(12): 1107-1109.

Young, J.D. 1987. "Chernobyl - the accident sequence." In Chernobyl - a technical appraisal' seminar. British Nuclear Energy Society, London, U.K.

Zebroski, E.L. 1986. "Review of nuclear power plant advanced concepts: Implications of the Chernobyl accident." In Intersociety energy conversion engineering conference. American Chemical Society, Washington, D.C., U.S.A.

Zehetner, F. 1986. "Chernobyl - on the problem of indemnification under international Taw." Umwelt-Planungsrecht 6(9):326-331.

Zehetner, F. 1986. "Chernobyl. Principles of international law in the context of transfrontier environmental pollution as a consequence of a technical-industrial disaster." Umwelt-Planungsrecht 6(6):201-205.

Zetterberg, H.L. 1987. "PubTic opinion and nuclear energy: Sweden after Chernobyl." In 11. annual symposium of the Uranium Institute. CONF-860915, Uranium Institute, London, U.K.

Ziegler, C.E. 1987. "The bear's view: Soviet environmentalism." Technol. Rev. $90(3): 44-51$.

Ziegler, E. 1987. "German Atomic Energy Law before and after the Chernobyl reactor accident. Recent developments within the Atomic Energy Law and the Radiation Protection Law." Energiewirtsch. Tagesfragen 37(4):353-360. 
Ziegler, E. (ed.). 1987. Atomic Energy Act with subordinate legislation. With an introduction by Dr.jur. E. Ziegter. (11th Edition). Nomos Verlagsges, Baden-Baden, Germany, F.R.

Ziesing, H.J. 1986. "Energy industry and energy policy in the Federal Republic of Germany now facing new challenges. Feasibility and consequences of a decision for immediate, medium-termed, or long-range dismissal of nuclear power." Parlam. Beil. Polit. Zeitgesch. 36(32):3-18.

Zischka, A. 1987. Chernobyl reactor accident - a non-accidential accident. The Soviet economy and the errors of the Western world. Unversitas Verl., Muenchen, Germany, F.R.

Zuck, R. 1986. "Legal aspects of the Chernobyl reactor accident." Monatsschr. Dtsch. Recht 8:639-641.

Zuehlke, P. 1986. "Accident in the Soviet nuclear power plant Chernoby1-4: Second report and supplementary information." Schweiz. Ver. Atomenerg., Bull. $28(10 / 11): 24-30$.

Zuend, H. 1988. "Is nuclear energy ethically justifiable?" Schweiz. Ver. Atomenerg. Bull. 30(18):25-37.

Zuend, H.: Fuchs, H. 1986. "Technical and operational aspects of the Chernobyl accident." BuTl. Assoc. Suisse Electr. 77(18):1177-1181.

Zuend, H.; Jarvis, A.S.; Haennis, H.P.; Tikal, J. 1986. "Safety philosophy and safety technology of the Soviet RBMK reactors." In SVA infomation meeting on safety of nuclear power plants in the light of TMI and Chernobyl. Schweizerische Vereinigung fuer Atomenergie, Bern, Switzerland.

Zuoyuan, W. 1987. "Radioactive contamination characteristics in China following Chernobyl accident." Zhonghua Fangshe Yixue Yu Fanghu Zazhi 7 (Supp 1.):8-11.

Zwigt, A. 1986. "Chernoby1, what happened?" Nuc]. Geneeskd. Bul1. 8(4):95-99. ---. 1986. "After Chernoby1. Protecting nuclear from the human factor." Financ. Times Eur. Energy Rep. 222:4-7.

---. 1986. "Annual expertise 1986/1987 of the Council of Economic Advisors." Drucksache-Dtsch. Bundestag 6562:1-297.

--- 1986. "Assessing Soviet nuclear technology - the case of Loviisa." Nucl. Eng. Int. $31(386): 27$.

--. 1986. "Basic information by the Commission of the Eurpean Communities of June 13, 1986, to the Council of Ministers on the consequences of the Chernobyl accident." Eur. Arch. 41(17):0473-0483. 
---. 1986. "Bibliographical notes on RBMK reactors." Nippon Genshiryoku Gakkaishi $28(9): 812-818$.

--- 1986. "CNA symposium explores Chernobyl accident." Nucl. Can. 25(9):1-2, 4.

-.-. 1986. "Chernobyl - a technical appraisal." Atom 362:14-17.

--- 1986. "Chernobyl - uncertainty remains. Radiation exposure during pregnancy." Muench. Med. Wochenschr. 128(23):29-32.

---. 1986. "Chernobyl accident sequence of events." Nucl. News 29(11):24.

--- 1986. Chernobyl accident. Hearing before the Committee on Energy and

Natural Resources, United States Congress, Second Session, June 19, 1986. Government Printing Office, Washington, D.C., U.S.A.

-.- 1986. "Chernobyl and the burning of sewage sludge. Administrative Court Berlin, decision of 23 May 1986." Unwelt-Planungsrecht 6(9):359-360.

---. 1986. "Chernobyl disaster: Can anyone really define the radiation hazards we're exposed to?" Bild Wiss. 23(6):28-34.

---. 1986. "Chernoby1 nuclear plant accident and international 1aw. International legal notes." Aust. Law J. 60(10):586-587.

--. 1986. "Chernobyl reaction: Harris, Seabrook hit; DOE backs Hanford-N." Nucl. News $29(9): 31-38$.

-.-. 1986. "Chernobyl report." Nature 323(6083):25-30.

--- 1986. "Chernobyl syndrome." Bulletin 108(5518):134-145.

---. 1986. "Chernoby1." Nachr. Chem., Tech. Lab. 34(8):771-776.

--- 1986. "Chernobyl. Consequences for the Federal Republic of Gemany. A documentation of the Association of German Engineers (VDI)." VDI-Nachr. $40(46): 1-46$.

-.. 1986. "Chernobyl. What really happened there?" KWU-Rep. 47:1-9.

-.-. 1986. "Chernobyl: 50,000 Bq - THTR: 0,1 Bq. Press release by the

THTR-300 operating company." Energiewirtsch. Tagesfragen $36(7): 558$.

-.-. 1986. "Chernobyl: tragedy of errors." Nucl. Eng. Int. 31(387):2-9.

--. 1986. "Continuing activity despite recession in many world regions."

Int. Power Generation 9(6):11-35.

---. 1986. "Cost of Chernoby1." Financ. Times Eur. Energy Rep. 216:19-24.

--- 1986. "Country profile: Hungary." OPEC Bull, 17(9):29-34, 70-7. 
-2. 1986. "Directive concerning compensation payable for reasons of equity for loss incurred with certain vegetable species (Directive on equitableness, vegetables) as of June 2, 1986." Gemeinsames Ministerialb1.. A

$37(17): 299-306$.

---. 1986. "Directive concerning the procedure for compensation of losses under section 38, sub-section 2 of the Atomic Energy Law as a consequence of the Chernobyl reactor accident (Compensation Directive), as of May 21, 1986." Gemeinsames Ministerialb]., A 37(15):250-259.

---. 1986. "Disaster cocktail. Chernobyl Special." Eur. Power News p. 1-4.

-... 1986. "Disaster under control, consequences not yet surveyable." Vangnet. $9(4): 16-19$.

--. 1986. "Discussion about the phase-out of nuclear energy." Energiewirtsch. Tagesfragen 36(10):767-768.

---. 1986. Energy and water development appropriations for 1987. Part 9. Hearings before a Subcommittee of the Committee on Appropriations, House of Representatives, Ninety-Ninth Congress, Second Session. Government Printing office, Washington, D.C., U.S.A.

---. 1986. "Energy in Europe. Energy policy and trends in the European Community." Energy Eur. 5:1-51.

--. 1986. "Energy policy after Chernobyl. Editorial." Pet. Econ. $52(7): 242-243$.

-.- 1986. "Energy policy and safety aspects of the nuclear energy debate. Thilo Koch talking to Dr.-Ing. Herbert Gassert, director of the BBC Co." Energie 38(10):12-15.

---. 1986. "Energy policy in the Federal Republic of Germany. Statements of the decision-making organs on energy policy." Energiewirtsch. Tagesfragen $36(12): 909-921$.

--- 1986. "Energy policy: Latest facts and figures. The effects of Chernobyl and low oil prices on energy policy." Kohle Heizoel 39(6):2-3.

---. 1986. "European Parliament, resolution of May 15, 1986 (consequences of Chernobyl for agriculture)." Eur. Grundrechte 13(14):443.

--- 1986. "European energy - new study highlights thermal coal import growth to year 2005." Int. Bulk J. 6(11):73-75.

--- 1986. "Facing facts - now or never." Ecologist 16(4-5):139.

--. 1986. "Flouristing market for radiation detectors in the wake of the Chernobyl disaster." Energie 38(6):53-58. 
--. 1986. "French Approach to Nuclear Safety." Clef CEA, Rev. Scj. Tech. $3: 23-31$.

-.-. 1986. "German Association for Food Legislation and Science. Annual meeting ' 86 . Lectures and papers." In Annual meeting of Bund fuer Lebensmitteirecht und Lebensmitte] kunde e.Y. Bund fuer Lebensmittelrecht und Lebensmittelkunde e.V., Bonn, Germany, F.R.

-.-. 1986. "Getting off is not an important issue in England and France. SZ correspondents report on Western Europe's nuclear perspective." Sueddtsch. Ztg. 42(139): 11 .

---. 1986. "Guideline for indemnification on the bas is of equitable considerations, to compensate for losses in connection with certain vegetables (equitable rule, vegetables), as of June 2, 1986." Bundesanzeiger $38(105): 7237$.

--. 1986. H.CON.RES. 342: expressing the sense of the Congress regarding continued operation of the Department's N-Reactor at the Hanford Reservation in the State of Washington, producing power for the Bonneville Power Administration. Government Printing Office, Washington, D.C., U.S.A.

--. 1986. H.J.RES. 674: joint resolution to direct the Chairman of the Nuclear Regulatory Commission to review, disseminate, and apply the recommendations of the report... regarding the nuclear accident at the Chernobyl nuclear facility in the Soviet Union. Government Printing office, Washington, D.C., U.S.A.

--. 1986. H.R. 5031: a bill to suspend the site selection process under the Nuclear waste Policy Act of 1982, and for other purposes. Introduced in the House of Representatives, Ninety-Ninth Congress, Second Session, June 12, 1986. Government Printing office, Washington, D.C., U.S.A.

--- 1986. H.R. 5121: a bill to require the Nuclear Regulatory Commission to conduct a study of the nuclear power reactor accident at Chernobyl, in the Soviet Union. Introduced in the House of Representatives, Ninety-Ninth Congress, Second Session, Jun. Government Printing office, Washington, D.C., U.S.A.

-.-. 1986. "Handling of maximum acceptable levels of radionuclide contamination of food." Drucksache-Dtsch. Bundestag 5935:1-11.

--- 1986. "IAEA experts' statement on Chernoby1." Nucl. Eur. 6(6):30.

--. 1986. "Information on the Chernobyl NPP accident and its consequencies prepared for IAEA." At. Energ. 61(5):301-320.

--- 1986. "International coordination of activities for establishing protective measures for the case of accidental release of radioactivity." 0eff. Gesundheitswes. 48:631-634. 
--- 1986. International nuclear safety concerns. Hearing before the Subcommittee on Energy, Nuclear Proliferation, and Government Processes of the Committee on Governmental Affairs, United States Senate, Ninety-Ninth Congress, Second Session, May 8, 1986. Government Printing Office, Washington, D.C., U.S.A.

---. 1986. "Koeberg compared." Financ. Mail 100(6):53.

---. 1986. "Legal interpretation by the Federal Minister of the Environment referring to the radioactive burden of agricultural products."

Drucksache-Dtsch. Bundestag 6008:1-10.

---. 1986. "Legal issues of Chernoby1. A statement of the German section of the AIDN/INLA." Energiewirtsch. Tagesfragen 36(6):515-516.

---. 1986. "Liability problems arising from nuclear reactor accidents." Drucksache-Dtsch. Bundestag 5821:1-7.

--.. 1986. "Living with radiation - after Chernobyl." Lancet $11(8507): 609-610$.

---. 1986. "Measurements at Mainz - Chernobyl reactor accident." Chem. Unserer Zeit 20(3):A26-A27.

---. 1986. "Non-budgetary expenditure from fund 0615, item 68101 compensatory payments in accordance with sec. 38(2) Atomic Energy Law, as a consequence of the Chernobyl reactor accident - within the fiscal year $1986 . "$ Drucksache-Dtsch. Bundestag 5946:1.

---. 1986. "Nuclear power in Europe: ECC report." Hansard, House Comnons 0ff. Rep. 482(5):348-427.

---. 1986. "Nuclear power: The price of getting off. Part 4. Turning to the sunny side." Wirtschaftswoche $40(26): 36-42$.

---. 1986. "Official announcement of an executive agreement between Federal German Government and Land governments, concerning payment of compensation for reasons of equity, for losses as result of the Chernobyl reactor accident." Bundesanzeiger 38(140): 10388-10389.

---. 1986. "Party conferences, 1986 and nuclear energy policy." Energy Focus $3(3): 171-174$.

---. 1986. "Physicians' reaction to Chernobyl explosion: lessons in radiation - and cooperation." J. Am. Med. Assoc. 256(5):559-561.

---. 1986. Positive safety features of US nuclear reactors: technical lessons confirmed at Chernobyl. Hearing before the Subcommittee on Energy Research and Production of the Committee on Science and Technology, US House of Representatives, Ninety-Nint. Government Printing Office, washington, O.C., U.S.A. 
-.-. 1986. "Press conference '20 years of experience in the construction and operation of nuclear reactors'." Electro-Rev. 78(13):23-25.

---. 1986. "Proceedings of the 32nd annual conference on bioassay, analytical and environmental radiochemistry." In 32. annual conference on bioassay, analytical and environmental chemistry. National Bureau of Standards, Gaithersburg, MD, U.S.A.

-.- 1986. Public information regarding radioactive emissions from nuclear power plants in North-Rhine Westphalia. Radiation protection report for April, May and June 1986. Ministerium fuer Wirtschaft, Duesseldorf, Germany, F.R.

--. 1986. "Putzmeister pumps for Chernobyl." Chantiers Fr. 193:34-35.

---. 1986. "RBMK: containment or not?" Nucl. Eng. Int. 31(389):27-28.

---1986. "Radiant smiles everywhere - before the Chernobyl accident. The situation of the electric utilities in the Federal Republic of Germany." Betriebstechnik 27(8):49-50.

--. 1986. "Radiation accidents and the role of the physician: a post-Chernobyl perspective." J.Am. Med. Assoc. 256(5):632-634.

---. 1986. "Radiation levels: WHO reports on Chernobyl. Experts estimate radiation dose commitment in Europe." IAEA Bull. 28(3):27-29.

---. 1986. "Radioactivity." Dig. Environ. Prot. Water Stat. 9:25-31.

-.- 1986. "Radioactivity." Oekopaed 6(3):1-32.

--- 1986. "Regulation concerning claims for compensation and their adjustment in accordance with section 38, subsection 2 Atomic Energy Act, as a consequence of the Chernobyl reactor accident (Regulation on Compensation) as of May 21, 1986." Bundesanzeiger 38(95):6417-6421.

--- 1986. Report of Committee of BUND Radiation Commission on food questions. Bund fuer Umwelt-und Naturschutz Deutschland e.V. (BUND), Bonn, Germany, F.R.

--- 1986. "Response to the Chernobyl accident in Japan." At. Jpn. 30(5):4-9.

-- 1986. S. 2556: a bill to suspend the site selection process under the Nuclear Waste Policy Act of 1982, and for other purposes. Introduced in the Senate of the United States, Ninety-Ninth Congress, Second Session, June 16 , 1986. Government Printing office, Washington, D.C., U.S.A.

---. 1986. S. 2571: a bill to establish the National Nuclear Reactor Safety Study Commission. Introduced in the Senate of the United States, Ninety-Ninth Congress, Second Session, June 19, 1986. Government Printing Office, Washington, D.C., U.S.A. 
--- 1986. S. Con. Res. 148: concurrent resolution expressing the sense of congress concerning the nuclear disaster at Chernobyl in the Soviet Union. Introduced in the Senate of the United States, Ninety-Ninth Congress, Second Session, June 13, 1986. Government Printing Office, Washington, D.C., U.S.A.

--. 1986. S.RES. 455: resolution to call for the creation of an early notification system for nuclear accidents. Introduced in the Senate of the United States, Ninety-Congress, Second Session, July 28, 1986. Government Printing office, Washington, D.C., U.S.A.

---. 1986. "Statement by Swiss industrial confederations on energy policy." Electro-Rev. $78(23): 29,31,33$, .

---. 1986. "Super MCA of Chernobyl. The worst nuclear accident so far frightens the whole world." Zeit $41(20): 9-15$.

-.-. 1986. "The accident in Chernobyl Nuclear Power Plant and coal gasification engineering by Ube Industries." Chem. Econ. Eng. Rev. $18(9): 10-11$.

--- 1986. "Time for a nuclear re-think." Coaltrans 1(1):13, 15.

---. 1986. US defensive operations against Libya and the nuclear accident at Chernobyl. Markup before the Committee on Foreign Affairs, House of

Representatives, Ninety-Ninth Congress, Second Session on H. Res. 424 and $H$. Res 440, May 1, 1986. Government Printing Office, Washington, D.C., U.S.A.

-.. 1986. "USSR documents causes of Chernobyl accident." Nucl. Eur. $6(10): 30-33$.

-.-. 1986. "Unbudgeted expenditure in chapter 1602, unbudgeted title $68112-2 / 3$ of indemnification to be paid by the Federal Government to contribute to the compensation to be paid according to the General Guideline on Compensation for Losses as a consequence." Drucksache-Dtsch. Bundestag 5969:1.

-... 1986. "Vermont Yankee study finds low risk of containment failure." Nuc 1. Eng. Int. 31(388):27-28.

-.-. 1986. "WHO assesses Chernobyl radiation in Europe." Nucl. Eur. $6(9): 29-32$.

--. 1986. "World Health Organization statement on Chernobyl." Nucl. Eur. $6(6): 31$.

--- 1987. 1986 Energy report (Italy). ENI, Rome, Italy.

--. 1987. "54th conference, proceedings." In 54. annual conference of the National Society for Clean Air. CONF-8710411, National Society for Clean Air, Brighton, U.K. 
--- 1987. "Association of Swiss Electrical Utilities. Council report on the 91 st year of operations." Bull. Schweiz. Elektrotech. Ver. 78(14):855-882.

.--. 1987. "Before Chernobyl: Savannah River." J. Am. Med. Assoc. $258(18): 2527-2528$.

---. 1987. "Can an application for shut-down of a nuclear power plant be successful on the grounds that the Chernobyl fallout enhances the local radiation exposure? OVG Lueneburg, decision of September 23, 1986." Unwelt-Planungsrecht $7(4): 153-155$.

--. 1987. "Chernoby1 and the consequences - one year after." Drucksache-Dtsch. Bundestag 755:1-35.

---. 1987. "Chernobyl radiation in Austria by far not overcome. Mushrooms with a radiation level of 2200 nanocuries found." Neue Argum. 8(33):6-8.

-.-. 1987. "Chocolate active." Strahlen Not. 15:v.

--. 1987. "Could Chernobyl happen here?" Nucl. Eur. 7(5):44.

---. 1987. Energy in Europe. Energy policies and developments in the European Communities. Bundesanzeiger Verl., Koeln, Germany, F.R.

-.-. 1987. "Evaluation of radioactive fallout from the Chernobyl reactor accident with regard to the drinking water supply." Bundesgesundheitsblatt $30(1): 31$.

--- 1987. "Executive order of the Federal Minister of the Environment, Nature Conservation, and Reactor Safety, on remedial radiation protection with regard to agricultural produce contaminated as a result of the Chernobyl reactor accident." Bundesrat-Drucksache 366:1 8.

-.-. 1987. Hanford Nuclear Reactor: safety issues. Hearing before the Subcommittee on Energy and Power of the Committee on Energy and Commerce, House of Representatives, One Hundredth Congress, First Session, February 10, 1987. Government Printing Office, Washington, D.C., U.S.A.

---. 1987. "If at first you don't succeed." 100A1 p. 2-4.

-.-. 1987. "Impacts of the Chernobyl nuclear power plant reactor accident on the territory of the GDR." Kernenergie 30(9):343-351.

--- 1987. "Information on the accident at the Chernobyl nuclear power station and its consequences prepared for IAEA." Sov. At. Energy $61(5): 845-868$.

--. 1987. "Interview with the Federal German Minister for Research and Technology, Dr. H. Riesenhuber." Energiewirtsch. Tagesfragen 37(1):7-9. 
---. 1987. "Is it morally justifiable to cont inue with the peaceful use of nuclear power? Report on a discussion meeting convened by the VDI Council for occupational Problems, gathering critics and supporters." VDI-Nachr. $41(49): 15$.

---. 1987. "Italian Radiation Protection Association (IRPA) Conference on Chernobyl Accident." In Conference AIRP sull'incidente di Chernobyl. Ass. It. Protezione Contro le Radiazioni, Bologna, Italy.

---. 1987. "Lessons from Chernobyl." Med. News Trib. 4(11):11-12.

---. 1987. "Long term plan of atomic energy development and utilization." Genshiryoku Shiryo 199:1-47.

---. 1987. "NRPB study reckons Chernobyl impact on European health will be tiny and undetectable." Nucl. Eur. 7(5):41.

---. 1987. Nuclear dialog. Verlags-und Wirtschaftsges. der Elektrizitaetswerke, Frankfurt am Main, Germany, F.R.

---. 1987. "Nuclear energy in Switzerland after Chernobyl - theses of SVA." Schweiz. Ver. Atomenerg., Bull. 29(10):19-22.

---. 1987. "Nuclear front abroad." Neue Argum. 8(34):7-8.

--- 1987. "Nuclear power: a year of incongruities." Energy 12(2):15-17.

---. 1987. "Nuclear risks - reassessing the principles and practice after Chernobyl." In Conference on nuclear risks - reassessing the principles and practical after Chernobyl. IBC Technical Services Ltd., London, U.K.

---. 1987. "Public announcement of a recommendation by the Strahlenschutzkommission (Radiation Protection Commission). As of October 12, 1987." Bundesanzeiger 39(208): 14750 .

---. 1987. "Radioactive fallout from Chernobyl has been found in the Greenland icecap." Environ. Sci. Technol. 21(10):934.

---. 1987. SIPRI yearbook of world armaments and disarmament, 1987. 0xford University Press, Oxford, U.K.

--- 1987. Soviet nuclear accident at Chernobyl. Briefing and hearing before the Subcommittee on Energy Conservation and Power of the Committee on Energy and Commerce, House of Representatives, Ninety-Ninth Congress, Second Session, May 1 and 7 , 1986. Government Printing Office, Washington, D.C., U.S.A.

---. 1987. "Swiss Association for Atomic Energy: Nuclear energy in Switzerland after Chernobyl." Bull. Schweiz. Elektrotech. Ver. $78(12): 722-725$. 
--- 1987. Types and classes of insurance. Nuclear insurance. Verl. Versicherungswirtschaft, Karlsruhe, Germany, F.R.

---. 1987. "Wackersdorf reprocessing plant." Atom 364:2-5.

-.-. 1987. "Westinghouse assesses $N$ reactor safety." Nucl. Eng. Int. $32(401): 21-22$.

--. 1987. "White paper on nuclear safety in 1986." Genshiryoku Anzen Hakusho $61: 1-9,1-389$.

---. 1987. "World status: international coal trade." Energy Econ. 66:17-20.

---. 1987. "World status: nuclear power." Financ. Times Energy Econ. 63:4-9.

---. 1988. "Dutch economy suffers from oil price falls despite Rotterdam's important refining industry." Financ. Times Eur. Energy Rep. 274:8-13.

-.-. 1988. "First report of the Civil Nuclear Power Working Group to the Technical Comittee of the National Society for Clean Air - Summer 1988." Clean Air 18(2):74-82.

---. 1988. "Food protection (Emergency prohibitions) order 1988 (Chernobyl contamination)." Hansard, House Lords. Off. Rep. 492(65):576-579.

--. 1988. "Massive reduction in noxious materials given off to the air." Electro-Rev. 80(12):54-55.

---. 1988. "NEA shows limited optimism." Energy Econ. 83:9-10.

-.-. 1988. "Profile Finland Part 1: trade with USSR and the desire for flexibility in energy supply spur on natural gas growth." Financ. Times Eur. Energy Rep. 267:8-13.

---. 1988. "Public announcement concerning the end of validity of the statutory ordinance on remedial radiation protection for agricultural produce that has been contaminated as a consequence of the Chernobyl reactor accident. As of January 6, 1988. "Bundesgesetzblatt, Teil I 2:82.

---. 1988. "Radiation exposure from X-ray and nuclear medical diagnostics compared to the natural exposure and that from the Chernobyl fallout." Dtsch. Roent. Inf. 1:9-14.

--- 1988. "Report on the prospects for the Community coal industry." Glueckauf 124(2):91-94.

-... 1988. "Results of radiation monitoring in the Geman Democratic Republic after Chernobyl." Isotopenpraxis 24(1):33-38.

--- 1988. "Was pump cavitation the key to Chernobyl?" Nucl. Eng. Int. $33(406): 18-19$. 
.... 1988. "World (nuclear) status report." Energy Econ. 75:15-20. 


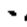




\section{DISTRIBUTION}

No. of

Copies

OFFSITE

10 DOE/Office of Scientific and Technical Information

Dr. Lynn R. Anspaugh

Lawrence Livermore National Laboratory

$L-453$

P.0. Box 5507

Livermore, CA 94550

Dr. Gilbert Beebe

Clinical Epidemiology Branch

Executive Plaza North, Suite 400

National Cancer Institute

Bethesda, MD 20892

Dr. Marvin Goldman

Laboratory for Energy-Related Health Research

University of California

School of Veterinary Medicine

Davis, CA 94616

Dr. Murray Schulman

U.S. Department of Energy

Office of Health and

Environmental Research

Washington, DC 20545

Or. Robert W. Hood

U.S. Department of Energy

Office of Health and

Environmental Research

Washington, DC 20545

\section{FORE IGN}

Or. Alica Bauman

Institute for Medical Research and Occupational Health

Zagreb

YUGOSLAVIA
No. of

Copies

Professor M.S. Baxter

Scottish Universities Research and Reactor Centre

East Kilbride

Strathclyde

SCOTLAND

Professor Anton Bayer

Bundesgesundhe itsamt

Institut fur Strahlenhygiene

Ingolstadter Landstrasse 1

D - 8042 Nueherberg

FEDERAL REPUBLIC OF GERMANY

Or. B.G. Bennett

United Nations Scientific

Committee on the Effects of

Atomic Radiation

Vienna International Centre

P.0. Box 500

A-1400 Vienna

AUSTRIA

Dr. D. Breitig

Universitat Uाm

Zentrale Einrichtung fur Isotopenanwendung

Postfach 4066 , D-7900 UTm

FEDERAL REPUBLIC OF GERMANY

Dr. Hans Brunner

c/o Sicherheit 9001, Geb. 2

PSI Paul Scherrer Institut

Wurenlingen und Villigen

CH-5232 Villigen PSI

FEDERAL REPUBLIC OF GERMANY

Mr. J.L. Butragueno

General Subdirector for Radiation Protection

Consejo de Seguridad Nuclear

c/ Justo Dorado, 11

28040 Madrid

SPAIN 
No. of

Copies

Mr. W. Camplin

Ministry of Agriculture, Fisheries, and Foods

Ergon House, c/o Nobel House

17 Smith Square

London SW1P 3JR

UNITED KINGDOM

Professọr Sir R.J. Clarke

Chaiman, Nationat Radiological

Protection Board

Chilton, Didcot

OxOn OX11 ORQ

ENGLAND

Mr. J.P. Cornet

Deputy Director, Radiation Protection

Ministry of Housing, Physical

Planning and Environment

P.0. Box 450

2260 MB Leidschendam

NETHERLANDS

Dr. Malcolm B. Cooper

Department of Community Services and Health

Australian Radiation Laboratory Lower Plenty Road

Yallambie, Victoria 3085

AUSTRALIA

Mr. J.D. Cunningham

Ass istant Chief Executive, Nuclear Energy Board

3 Clonskeagh Square

Clonskeagh Road

DubT in 14

IRELAND

Dr. Wu De-Chang

Institute of Radiation Medicine

11\# Tai Ping Road

Beijing

THE PEOPLE'S REPUBLIC OF CHINA
No. of

Copies

\author{
Dr. Gunter Drexler \\ Gesellschaft fur Strahlenund \\ Unwelt forschung mbH \\ Ingolstadter Landstrasse 1 \\ D-8042, Neuherberg \\ FEDERAL REPUBLIC OF GERMANY
}

Mr. A. 0. de Bettencourt

Director do Departamento de Proteccao e Seguranca Radiologica

Laboratorio Nacional de Engenharia e Technologia Industrial (LNETI)

Estrada Nacional 10

Sacavem

PORTUGAL

Dr. F. Girardi

Division Head, Nuclear Fuel Cycle Safety

EC Joint Research Center

21020 ISPRA

Varese

ITALY

Dr. I. Hall

The Scottish Office

HMIP, 1st Floor

27 Perth Street

Edinburgh EH 3 5RD

SCOTLAND

Dr. R. Hancock

Technology Planning and Research Division

Berkeley Nuclear Laboratories

Berkeley, Gloucestershire GL13 $9 \mathrm{~PB}$

UNITED KINGDOM

Dr. Alfred Hefner

Secretary, 0evS

Austrian Research Center

Seibersdorf

A-2444 Seibersdorf

AUSTRIA 
No. of

Copies

Dr. Walter Huda

Department of Medical Physics Manitoba Cancer Treatment and

Research Foundation

100 0livia Street

Winnipeg, Manitoba R3E ovg

CANADA

0 . Ilair

Secretariat

Committee on Radiation

Protection and Public Health

OECD Nuclear Energy Agency

Paris

FRANCE

Dr. Wolfgang Jacobi

Institut fur Strahlenschutz

D-8042 Neuherberg

Post Schlessheim

Ingolstaddter Landstrasse 1

FEDERAL REPUBLIC OF GERMANY

Dr. Wen Jianhua

Secretary, Science and

Technology Administration

China Institute for Radiation

Protection

P.0. Box 120, Taiyuan, Shanxi

PEOPLE'S REPUBLIC OF CHINA

Dr. M.W. Jones

Department of the Environment, HMIP

Romney House

43 Marsham Street

London SWIP 3PY

ENGLAND

Dr. Bo Linde11

Director

Statens Stralskyddesinstitut

Fack S-104 01 Stockholm

SWEDEN
No. of

Copies

Dr. Dorothy P. Meyerhof

Chief, Environmental Radiation Hazards Division

Bureau of Radiation and Medical Devices

775 Brookfield Road

ottawa, Ontario

K1A 1C1

CANADA

Dr. Osamu Matsuoka

Chief, National Institute of Radiological Sciences

Division of Comparative Radiotoxicology

9-1 Anagawa-4-Chome

Chiba-shi

JAPAN 260

Dr. Francesco Mauro

Divisione di Fiscica e Scienze Biomediche

ENEA

Casaceia

00060 Rome

ITALY

Dr. Pietro Metalli

Laboratorio di Radiopatologia

National Committee of Nuclear Energy (CNEN)

Casaccia Centre for Nuclear Studies (CSN)

Casella Postale 2400

00100 Roma

ITALY

Mr. Ronald Page

The Welsh office

Cathays Park

Cardiff CF1 3NQ

WALES

Dr. H.G. Paretzke

GSF Institut fur Strahlenschutz

D-8042 Neuherberg

FEDERAL REPUBLIC OF GERMANY 
No. of

Copies

Mr. S. Pretre

Head, Division of Radiation Protection

Nuclear Safety Inspectorate

Swiss Federal Office of Energy

$\mathrm{CH}-5303$ Wurentingen

SWITZERLAND

Dr. Anneli Salo

Finish Centre for Radiation and Nuclear Safety

Surveillance Department

P.0. Box 268

SF-00101 Helsinki

FINLAND

Mr. J.P. Samain

Chef du Service de Protection contre les Radiations Ionisantes

Ministere de la Sante Publique et de l'Environnement

Cite Administrative

Quartier Vesale, $D / 3 / 27$

B-1010 Bruxelles

BELGIUM

Dr. J. Schwibach

Institut for Strahlenhygiene des Bundesgesundhejtsantes

Ingolstadter Landster

1, D-8042 Neuherberg

FEDERAL REPUBLIC OF GERMANY

Dr. J.0. Snihs

Statens Stralskyddsinstitut

Box 60204

10401 Stockholm

SWEDEN

Dr. Friedrich Steinhausler Institute of General Biology, Biochemistry, and Biophysics

Department of Biophysics

Hellbrunner Strasse 34

A-5020 Salzburg

AUSTRIA
No. of

Copies

Dr. D.M. Taylor

Kernforschungzentrum Karlsruhe Institut fur Strahlenbiologie

75 Karlsruhe 1

Postfach 3640

FEDERAL REPUBLIC OF GERMANY

J. Van Kempen

Deputy Head Radioactivity and Radiation Applications Division

Ministry of Welfare, Health and Cultural Affairs

Postbus 5406

2280 HK Rijswijk

NETHERLANDS

Dr. V1adimir Volf

Kernforschungzentrum Karlsruhe

Institut fur Strahlenbiologie

Postfach 3640

75 Karlsruhe 1

FEDERAL REPUBLIC OF GERMANY

J. I an Haddington

World Health Organization

Regional office for Europe

8 Scherfigsvej

DK-2100

Copenhagen

DENMARK

Dr. Ole Walmod-Larsen

Riso National Laboratories

Department of Health Physics

DK-4000 Roskilde

DENMARK

Dr. Chen Xing-an

Laboratory of Industrial Hygiene

Ministry of Public Health

2 Sinkang Street

Deshangmanwai, Beijing 100011

THE PEOPLE'S REPUBLIC OF CHINA 
No. of

Copies

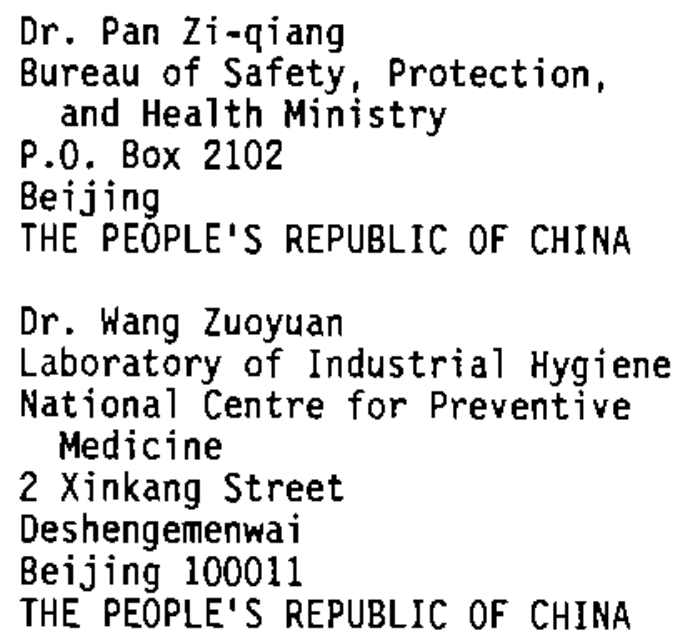

ONSITE

DOE Richland Operations Office

P.W. Kruger

60 Pacific Northwest Laboraotry

W.J. Bair

F. Carr, Jr.

E.S. Gilbert (7)

J.R. Johnson

W.E. Kennedy

J.A. Mahaffey (25)

J.B. Martin

B.A. Napier

J.K. Soldat

W.L. Templeton (12)

T.S. Tenforde

J.D. Zimbrick

Publishing Coordination (2)

Technical Report Files (5) 
